\author{
CECÍLIA KANETO OLIVERIO
}

\title{
O DIREITO AO DESENVOLVIMENTO E O COMÉRCIO INTERNACIONAL DE SERVIÇOS EDUCACIONAIS
}

DISSERTAÇÃO DE MESTRADO

PROFESSORA ORIENTADORA:

DR. ${ }^{a}$ CLÁUDIA PERRONE MOISÉS

FACULDADE DE DIREITO DA UNIVERSIDADE DE SÃO PAULO

- SÃO PAULO -

- 2009 - 


\author{
CECÍLIA KANETO OLIVERIO
}

\title{
O DIREITO AO DESENVOLVIMENTO E O COMÉRCIO INTERNACIONAL DE SERVIÇOS EDUCACIONAIS
}

Dissertação apresentada ao
Programa de Pós-Graduação em
Direito, do Departamento de
Direito Internacional e Comparado
da Faculdade de Direito da
Universidade de São Paulo, como
requisito parcial para a obtenção do
título de mestre.

PROFESSORA ORIENTADORA: DR. ${ }^{a}$ CLÁUDIA PERRONE MOISÉS

FACULDADE DE DIREITO DA UNIVERSIDADE DE SÃO PAULO

- SÃO PAULO -

- 2009 - 
... a parte mais bela e importante de toda a História: a revelação de que todos os seres humanos, apesar das inúmeras diferenças biológicas e culturais que os distinguem entre si, merecem igual respeito, com únicos entes do mundo capazes de amar, descobrir a verdade e criar a beleza. É o reconhecimento universal de que, em razão dessa radical igualdade, ninguém - nenhum indivíduo, gênero, etnia, classe social, grupo religioso ou nação - pode afirmar-se superior aos demais.

Fábio Konder Comparato

A educação é o ponto em que decidimos se amamos o mundo o bastante para assumirmos a responsabilidade por ele e, com tal gesto, salvá-lo da ruína que seria inevitável não fosse a renovação e a vinda dos novos e dos jovens.

Hannah Arendt 


\section{AGRADECIMENTOS}

À querida Professora Cláudia, que me ensinou a importância e a beleza da vida acadêmica, pelo incentivo e atenção, pelo apoio e pela calma, pelos ensinamentos e orientações, que exprimem o verdadeiro valor da atividade docente, o meu mais caloroso agradecimento.

Aos meus queridos pais, Orlando e Jacira, sem os quais nada em minha vida teria sido possível, pelo apoio constante, pela fé e confiança, pela paciência e pelo amor e carinho eternos, obrigada por tudo.

À minha amada irmã, Julia, com quem compartilho minha alma, pelo amor e carinho, pelos sorrisos e abraços, sem os quais a vida não teria a mesma graça.

Ao meu Fá, pela compreensão e paciência, pelo companheirismo incondicional, pelo amor e carinho infinitos, pelo seu olhar e por acreditar em mim.

Às amigas queridas de Mestrado, Camila e Thana, por compartilharem meus sucessos e angústias, pelos trabalhos conjuntos, pela ajuda constante na elaboração da Dissertação e pelos momentos de descontração, que tornaram as atividades acadêmicas muito menos solitárias.

À amiga Lúcia, pela experiência e pelos ensinamentos, dignos do seu espírito de professora.

Aos professores Umberto Celli Jr. e André de Carvalho Ramos, pelas valiosas contribuições à minha pesquisa e pela participação no meu Exame de Qualificação.

Aos meus amigos e amigas queridos, pela eterna torcida.

Ao SasakawaYoung Leaders Fellowship Fund, pelo incentivo e confiança, especialmente aos Professores Carlos Azzoni, Adalberto Fishmann e João Grandino Rodas, pelas constantes contribuições durante a redação deste trabalho; à Malu, pela paciência e ajuda de prontidão e aos demais bolsistas, que contribuíram com suas questões e observações e me ensinaram muito com suas pesquisas.

À querida Edna, pela simpatia, pela torcida e pelo carinho.

Por fim, a Deus, que permitiu que tantas pessoas maravilhosas entrassem em minha vida e que me dá a fé, a força e as condições necessárias para a realização dos meus sonhos. 


\section{RESUMO}

O presente estudo pode ser considerado parte da linha de pesquisa Comércio, Direitos Humanos e Desenvolvimento, temática recorrente que procura entender e analisar os impactos do comércio internacional na realização dos direitos humanos e no desenvolvimento, além de propor alternativas sobre o inter-relacionamento das três áreas. A integração positiva entre elas depende de muito mais do que a adoção de medidas preventivas contra os possíveis prejuízos advindos da liberalização. Um sistema de comércio internacional que seja realmente favorável aos direitos humanos e ao desenvolvimento - entendido não apenas como benefício econômico, mas principalmente como desenvolvimento social, político e cultural -, deve ir além e atuar de forma positiva e não passiva. Neste sentido, não se pode considerar a liberalização dos serviços educacionais no âmbito da Organização Mundial do Comércio (OMC), se não forem conduzidas de forma a contribuir para a realização do direito ao desenvolvimento em todas as nações e a todos os indivíduos. No entanto, evidenciada existência de um atual "mercado educacional", deve-se buscar alternativas para colocar a realização do direito ao desenvolvimento - um direito humano que garante a realização de diversos outros direitos humanos - no topo dos objetivos do comércio internacional. Assim, é obrigatório que se procure encontrar uma maneira de negociar o setor de serviços educacionais que não prejudique e ainda colabore para uma implementação mais efetiva do direito ao desenvolvimento. Objetivando cooperar com este relevante e necessário propósito, este estudo discute a atual relação entre o comércio internacional de serviços educacionais e o direito ao desenvolvimento, bem como analisa a importância da educação para os direitos humanos e o desenvolvimento. Afinal, a educação deve ser vista como uma "mercadoria liberalizável" ou deve ser tratada, acima de tudo, como um direito humano e um bem público, que deve ser protegido?

Palavras-chave: Direito ao desenvolvimento - Comércio internacional de serviços educacionais - GATS - Direito à educação - Bens públicos. 


\begin{abstract}
This study can be considered as part of the current research under Trade, Human Rights and Development, that intends to understand and evaluate the impacts of international trade at human rights and development, besides proposing alternatives to relate all three areas. Integrating international trade, realization of human rights, and development depend on much more than just preventing consequential damages of trade liberalization. An international trade system that is really favorable to development - considered not only as economical gain, but also as social, political and cultural development - and human rights must go further, and act positively rather than just passively. In this scenario, negotiating education services at the World Trade Organization (WTO) in a way that does not contribute to the realization of the right to development in all nations and for all human beings can not be considered welcome or even feasible. However, bearing in mind that there is already an "education market", reality claims for alternatives to put the realization of the right to development - as a human right that guarantees several other fundamental rights - at the top of international trade goals. Therefore, finding a way of liberalizing education services that does not hinder and yet cooperates to a more effective implementation of the right to development is now mandatory. Aiming to cooperate with this relevant and necessary purpose, this study discuss the current relation between international trade in education services and the right to development, as well as the importance of education to human rights and development. After all, should education be seen as international trade "commodity" or should it be treated, above all, as a human right and a public good in need of protection?
\end{abstract}

Key-words: Right to development - International trade in education services - GATS Right to education - Public goods. 


\section{LISTA DE ABREVIATURAS}

$\begin{array}{ll}\text { CAPES } & \text { Fundação Coordenação de Aperfeiçoamento de Pessoal de Nível Superior } \\ \text { CEPAL } & \text { Comissão Econômica das Nações Unidas para a América Latina e o Caribe } \\ \text { CES } & \text { Câmara de Educação Superior } \\ \text { CNE } & \text { Conselho Nacional de Educação } \\ \text { ECOSOC } & \text { Comitê Econômico e Social das Nações Unidas } \\ \text { EUA } & \text { Estados Unidos da América } \\ \text { FMI } & \text { Fundo Monetário Internacional } \\ \text { GATS } & \text { Acordo Geral sobre o Comércio de Serviços (General Agreement on Trade } \\ & \text { in Services) } \\ \text { GATT } & \text { Acordo Geral sobre Tarifas e Comércio (General Agreement on Tariffs and } \\ & \text { Trade) } \\ \text { IDH } & \text { Índice de Desenvolvimento Humano } \\ \text { INEP } & \text { Instituto Nacional de Estudos e Pesquisas Educacionais } \\ \text { LDB } & \text { Lei de Diretrizes e Bases da Educação Brasileira } \\ \text { MEC } & \text { Ministério da Educação e Cultura } \\ \text { MERCOSUL } & \text { Mercado Comum do Sul } \\ \text { OCDE } & \text { Organização para Cooperação e Desenvolvimento Econômico } \\ \text { ODM } & \text { Objetivos de Desenvolvimento do Milênio } \\ \text { OEA } & \text { Organização dos Estados Americanos } \\ \text { OIC } & \text { Organização Internacional do Comércio } \\ \text { OIT } & \text { Organização Internacional do Trabalho } \\ \text { ONG } & \text { Organização não-Governamental } \\ \text { OMC } & \text { Organização Mundial do Comércio } \\ \text { ONU } & \text { Organização das Nações Unidas } \\ \text { PIB } & \text { Produto Interno Bruto } \\ \text { PNE } & \text { Plano Nacional da Educação } \\ \text { PNUD } & \text { Programa das Nações Unidas para o Desenvolvimento } \\ \text { TRIMS } & \text { Medidas de Investimento Relacionadas ao Comércio (Trade Related } \\ \text { UE } & \text { Investment Measures) } \\ \text { UNCTAD } & \text { União Européia } \\ \text { Conferência das Nações Unidas sobre Comércio e Desenvolvimento (United } \\ \text { UNESCO } & \text { Nations Conference on Trade and Development) } \\ \text { Organização das Nações Unidas para a Educação, a Ciência e Cultura } \\ \text { Fundo das Nações Unidas para a Infância (United Nations Children’s Fund) }\end{array}$




\section{SUMÁRIO}

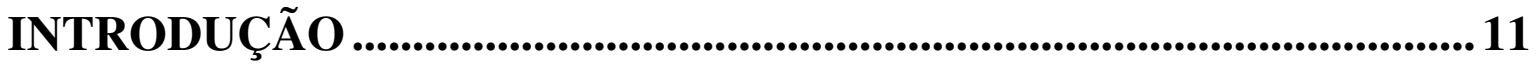

\section{I - COMÉRCIO, DESENVOLVIMENTO E DIREITOS}

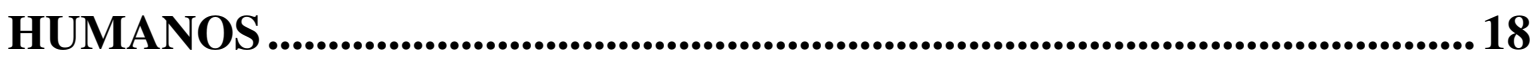

1.1. LIBERALIZAÇÃO, CRESCIMENTO ECONÔMICO E

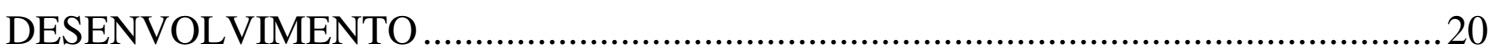

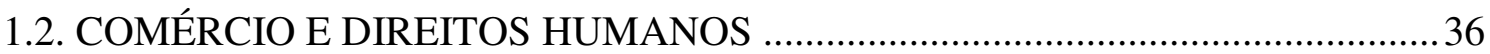

II - O DIREITO AO DESENVOLVIMENTO .........................................48

2.1. A EVOLUÇÃO DO CONCEITO DE DESENVOLVIMENTO .............................50

2.2. HISTÓRICO DO DIREITO AO DESENVOLVIMENTO ...................................60

2.2.1. A Declaração sobre o direito ao desenvolvimento ..........................................62

2.2.2. A construção do direito ao desenvolvimento como direito humano: os próximos grupos de trabalho e a Declaração de Viena...................................................................6

2.3. O CONTEÚDO DO DIREITO AO DESENVOLVIMENTO ...............................68

2.3.1. Fundamentos e fontes do direito ao desenvolvimento.................................... 72

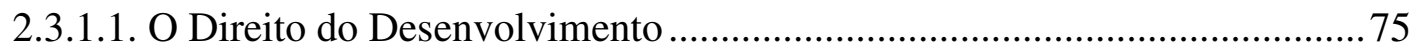

2.3.2. A natureza jurídica do direito ao desenvolvimento .......................................78

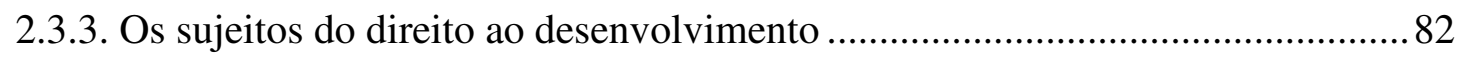

2.3.4. A responsabilidade do Estado e o papel da cooperação internacional ............... 86

2.4. A EDUCAÇÃO E O DIREITO AO DESENVOLVIMENTO ...............................89

III - O DIREITO À EDUCAÇÃO..............................................................92 


\subsection{A EDUCAÇÃO COMO DIREITO: CAMINHOS PARA O}

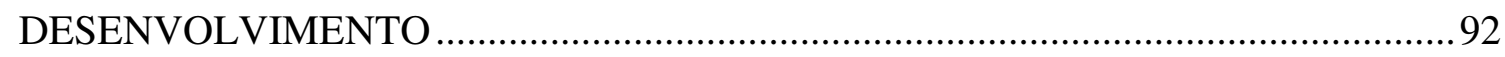

3.1.1. O reconhecimento internacional do direito à educação ................................... 94

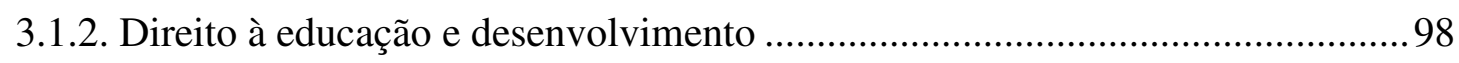

3.2. O CONTEÚDO DO DIREITO À EDUCAÇÃO ................................................ 101

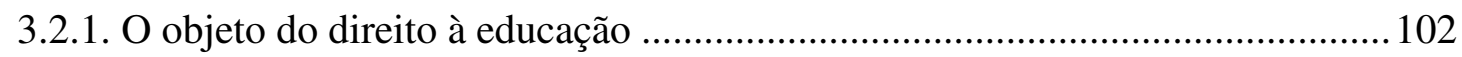

3.2.2. O sujeito ativo do direito à educação .......................................................... 104

3.2.3. Os sujeitos passivos: deveres decorrentes do direito humano à educação ....... 105

3.3. OS PRINCÍPIOS INTERNACIONAIS DO DIREITO À EDUCAÇÃO ................ 107

3.4. ELEMENTOS ESSENCIAIS DA PRESTAÇÃO DOS SERVIÇOS

EDUCACIONAIS: OBRIGAÇÕES DECORRENTES DO DIREITO HUMANO À

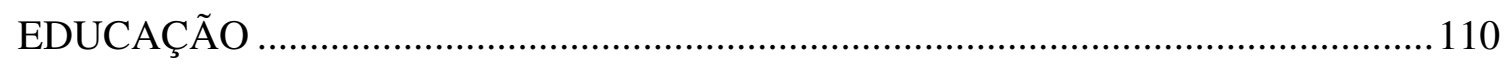

3.5. A EDUCAÇÃO COMO BEM PÚBLICO.......................................................... 112

3.6. O ENSINO SUPERIOR: UM DIREITO À EDUCAÇÃO ................................... 115

3.6.1. Reafirmando a educação superior como direito humano................................. 116

3.6.2. Educação superior e desenvolvimento....................................................... 118

3.7. A EDUCAÇÃO COMO DIREITO HUMANO NO BRASIL .............................. 122

3.8. A PARTICIPAÇÃO PRIVADA NA EDUCAÇÃO E O PAPEL DO ESTADO... 126

3.9. EDUCAÇÃO E COMÉRCIO INTERNACIONAL: UMA INTRODUÇÃO À

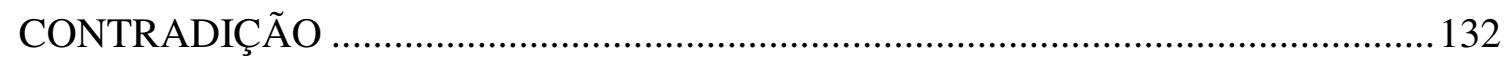

\section{IV - O COMÉRCIO INTERNACIONAL DE SERVIÇOS}

EDUCACIONAIS

4.1. O PROCESSO DE REGULAMENTAÇÃO MULTILATERAL DO COMÉRCIO DE SERVIÇOS 
4.2. AS PARTICULARIDADES DA PRESTAÇÃO INTERNACIONAL DOS

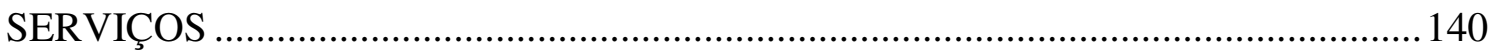

4.3. O ACORDO GERAL SOBRE COMÉRCIO DE SERVIÇOS (GATS)................. 142

4.3.1. Os modos de prestação dos serviços ............................................................. 144

4.3.2. Princípios e obrigações do comércio de serviços ............................................. 146

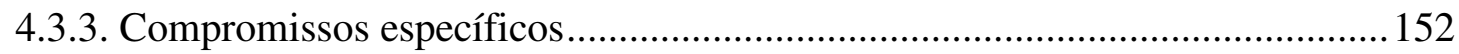

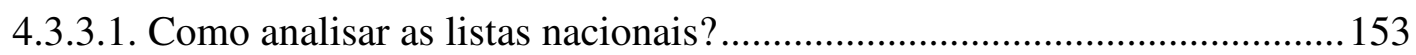

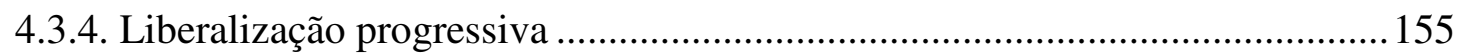

4.4. AS NEGOCIAÇÕES DE SERVIÇOS E A RODADA DOHA ............................ 156

4.5. OS SERVIÇOS DE EDUCAÇÃO E AS REGRAS DE LIBERALIZAÇÃO

COMERCIAL: APESAR DA CONTRADIÇÃO......................................................... 158

4.5.1. Definição e classificação dos serviços educacionais no GATS....................... 159

4.5.2. As negociações comerciais dos serviços educacionais: propostas e compromissos

4.5.3. A educação e os serviços prestados no exercício da autoridade

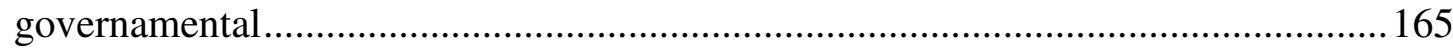

4.5.4. Os impactos dos compromissos de liberalização comercial sobre a

educação.

4.6. A POSIÇÃO BRASILEIRA E O DIREITO CONSTITUCIONAL À EDUCAÇÃO

4.7. "MERCADO EDUCACIONAL" VERSUS DIREITO AO

DESENVOLVIMENTO

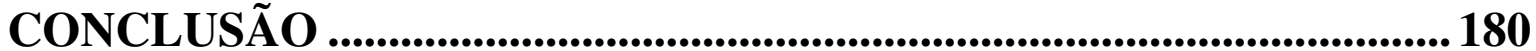

BIBLIOGRAFIA 


\section{INTRODUÇÃO}

O tema do presente estudo insere-se na temática Comércio, Direitos Humanos e Desenvolvimento, linha de pesquisa bastante atual e em grande desenvolvimento, desde a consolidação da percepção de que as relações comerciais entre os países causam impactos na realizabilidade dos direitos humanos e nas possibilidades de desenvolvimento das nações e indivíduos.

Assim, essa linha de estudo tem procurado entender e avaliar os impactos do comércio internacional nos direitos humanos e no desenvolvimento, além de propor métodos para que a inevitável aproximação entre esses três temas possa produzir benefícios aos seres humanos e a toda comunidade internacional.

A evolução dos estudos dentro desta temática levou ao reconhecimento de um novo e necessário direito humano: o direito ao desenvolvimento, baseado na concepção que veio a se formar de que o desenvolvimento não poderia estar restrito à aferição de resultados econômicos, mas deveria englobar outros fatores que o tornam mais relevante, colocando-o entre as principais preocupações do Direito Internacional, pois o aproximam de questões sociais, políticas e culturais.

A incorporação dessas dimensões ao desenvolvimento decorre da constatação de que os resultados econômicos do desenvolvimento não são suficientes para garantir o bem-estar dos indivíduos em todos os países, já que o cenário de desigualdades - tanto no plano internacional, entre as diversas nações, quanto no plano interno, entre classes de indivíduos - se aprofunda cada vez mais, apesar de crescentes avanços tecnológicos, das iniciais esperanças de compartilhamento de conhecimento e do rápido crescimento econômico evidenciado, a partir do fim da Guerra Fria e da aceleração do processo de globalização.

Acreditava-se que a liberalização do comércio contribuiria para o desenvolvimento de todas as nações, que poderiam participar de forma igual no comércio internacional. No entanto, as desigualdades entre os países apenas reafirmaram a clássica noção aristotélica de que a igualdade formal entre os participantes não é suficiente para garantir a divisão igualitária dos benefícios da liberalização, ou seja, a desigualdade econômica e social entre 
os Estados impede que as relações internacionais sejam efetivamente justas. Por isso a importância do alargamento do conceito de desenvolvimento.

Ao mesmo que o conceito de desenvolvimento era ampliado e que o direito humano ao desenvolvimento se consolidava, o comércio internacional se desenvolvia, sendo que as mercadorias comercializáveis através das fronteiras nacionais se diversificavam e passavam a abarcar também serviços e não apenas bens tangíveis. Natural e rapidamente, essas "novas" mercadorias tornavam-se mais importantes para a economia dos países, que desejam, conseqüentemente, uma maior regulamentação internacional sobre o comércio de serviços, a fim de buscarem a abertura desses mercados.

O tema serviços, portanto, vai se inserindo nas agendas de discussões das organizações internacionais de cunho econômico, culminando com a criação do Acordo Geral sobre o Comércio de Serviços (GATS), que estabelece como princípio a liberalização de diversos setores de serviços, inclusive serviços básicos essenciais, tais como os serviços educacionais.

A contraposição entre o crescimento do comércio internacional de serviços, em busca de maiores compromissos pela liberalização e a ampliação do espaço conquistado pelo direito ao desenvolvimento fundamentando as reivindicações pela primazia dos direitos humanos em todas as relações internacionais, formou um cenário que despertou a atenção dos governos nacionais, das organizações internacionais, da sociedade civil e da academia, os quais logo notaram que a inserção de serviços básicos, como a educação, na OMC parecia chocar-se com a consolidação do direito ao desenvolvimento como direito humano.

Isso porque, no âmbito da $\mathrm{OMC}$, o enfoque é dado aos objetivos econômicos da liberalização, enquanto o reconhecimento do direito humano ao desenvolvimento pressupõe colocar a realização plena de todos os direitos humanos como principal propósito das relações internacionais.

Assim, a educação, enquanto inserida no GATS, teria de obedecer aos princípios econômicos do livre-comércio, sendo que a sua principal finalidade seriam as vantagens econômicas resultantes da abertura comercial no setor. Ao mesmo tempo, no entanto, a educação, enquanto meio e fim do direito ao desenvolvimento, é reafirmada como direito humano universal e inalienável, ao qual os Estados e a comunidade internacional estão 
comprometidos e pelo qual são responsáveis, devendo promover e garantir a sua plena realização, antes de buscar possíveis vantagens econômicas.

Percebe-se, portanto, que há uma inversão de prioridades, dependendo do enfoque que se é dado à educação e do âmbito em que se encontra inserida. Essa situação tem preocupado os defensores dos direitos humanos, que temem conseqüências prejudiciais resultantes dessa inversão.

Neste contexto, o presente trabalho se propõe a apresentar essa relação contraditória entre o crescimento do comércio internacional de serviços educacionais e a importância da educação para a realização do direito ao desenvolvimento.

Para alcançar este objetivo, a Dissertação foi dividida em quatro capítulos principais. No primeiro capítulo, apresenta-se a linha de pesquisa em que se insere a análise proposta, qual seja, aquela que observa as relações entre o comércio, o desenvolvimento e os direitos humanos.

Nesta ocasião, realizar-se-á uma introdução aos conceitos de crescimento econômico e desenvolvimento econômico, para relacioná-los ao comércio internacional. Também se avalia o desenvolvimento dos direitos humanos, que ao ganharem espaço cada vez maior no plano internacional, passam a exigir determinadas cautelas em todas as relações internacionais.

Neste sentido, diante da ampliação das regras de comércio internacional, passando a envolver cada vez mais áreas que afetam a fruição dos direitos humanos, tornou-se mais evidente que o comércio internacional e os direitos humanos interagem.

Após a explicação do que é a temática em que se insere o presente trabalho, passa-se a apresentar o direito ao desenvolvimento. Para tanto, desenvolve-se inicialmente um histórico sobre a evolução do conceito de desenvolvimento. Em seguida, é apresentado o processo de afirmação do direito ao desenvolvimento como direito humano, bem com suas diversas dimensões e características.

Por fim, o capítulo II introduz a relação entre a educação e o direito ao desenvolvimento, a fim de abrir caminho para o conteúdo do próximo capítulo, que discorre sobre o direito humano à educação. 
Neste terceiro capítulo, são apresentados diversos aspectos do direito à educação, com especial ênfase aos princípios e regras internacionais que norteiam a sua realização. Além disso, discorre-se sobre a relação entre a educação e os índices de desenvolvimento, em todos os seus sentidos. Ainda, é dado especial enfoque ao ensino superior, com o objetivo de afirmá-lo como parte indispensável do direito humano à educação, sem a qual a realização deste direito não é plena.

Também apresenta-se a situação da educação como direito humano no ordenamento jurídico brasileiro, a fim de ilustrar os compromissos que o país possui para com esse direito. Ao final deste capítulo, são apresentadas primeiras notas sobre a mercantilização da educação.

O quarto e último capítulo diz respeito ao comércio internacional de serviços educacionais. Há uma apresentação inicial sobre a regulamentação internacional do comércio de serviços na OMC, por meio do GATS, para posteriormente apresentar as particularidades do setor educacional. Convém lembrar que as discussões sobre o comércio internacional de serviços ainda são poucas - em ainda menor quantidade no que tange ao comércio de serviços educacionais -, quando equiparadas ao comércio de bens, sobre os quais ainda recai grande parte dos estudos sobre o comércio internacional.

Ao final do presente trabalho, procura-se provocar nos leitores alguns questionamentos que emergem das análises feitas no presente trabalho, mas cujas possíveis respostas não cabem como proposta de uma dissertação de mestrado.

Assim, espera-se despertar o interesse pelas algumas possíveis questões, como: (i) a liberalização do comércio de serviços educacionais pode ou não contribuir para a realização dos direitos humanos à educação e ao desenvolvimento?; (ii) de que forma as negociações em serviços na OMC devem ser levadas a fim de garantir a proteção desses direitos nos países em desenvolvimento e de menor desenvolvimento relativo?; (iii) quais compromissos podem ser assumidos pelos países mais pobres e emergentes?; (iv) quais as possíveis implicações - sociais, econômicas e políticas - de uma liberalização despreocupada do setor para os indivíduos e para os países?; (v) existe uma forma moderada de liberalização que pode contribuir para os direitos humanos e para o desenvolvimento?; (vi) quais os verdadeiros interesses na liberalização do setor e quem sofrerá as maiores perdas com a abertura comercial?; (vii) quais os possíveis impactos da liberalização no mercado brasileiro e na realização do direito ao desenvolvimento no país? 
Ressalte-se que muitos autores já trataram e continuam a se pronunciar sobre questões significativas para a discussão proposta, assim como já há vasta manifestação de organizações internacionais de importante representação no sentido de reconhecer o direito ao desenvolvimento e o impacto das relações comerciais para a sua implementação efetiva.

Já existem também diversos estudos de organizações internacionais e de atores da sociedade civil que avaliam os impactos da liberalização do comércio de serviços educacionais, acompanham as negociações deste setor na OMC e refletem sobre as implicações de uma liberalização desenfreada do setor. Além disso, muitos estudos também analisam o papel do direito à educação e do direito ao desenvolvimento.

A Professora Cláudia Perrone Moisés ${ }^{1}$, por exemplo, tratou da relação entre a realização do direito ao desenvolvimento e a questão dos investimentos estrangeiros, destacando a importância do debate sobre o impacto das relações econômicas internacionais na proteção dos direitos humanos. Nesse estudo, a autora ressalta que "os foros econômicos $e$ comerciais parecem estar bloqueados para o encaminhamento das questões ligadas ao desenvolvimento". E continua lembrando "que a importância cada vez maior dos direitos humanos na ordem internacional se confirma também no que se refere a temas econômicos".

O Professor Umberto Celli Jr. ${ }^{2}$, cuja principal linha de pesquisa é o comércio internacional de serviços, atenta para "o conflito vivido por países em desenvolvimento que, de um lado, buscam criar condições para o desenvolvimento e crescimento de certos setores domésticos e, de outro, não podem se descuidar da observância das regras dos acordos comerciais internacionais".

Arjun Sengupta ${ }^{3}$, em seu relatório como perito independente para o Direito ao Desenvolvimento, da ONU, ao discorrer sobre um plano de realização do direito ao desenvolvimento, ressalta a importância das obrigações da comunidade internacional e de países desenvolvidos de possibilitar igualdade de participação e tratamento no processo de tomada de decisões nas operações do sistema multilateral do comércio, bem como de remover quaisquer políticas discriminatórias ou obstáculos que impeçam ou dificultem o acesso dos países em desenvolvimento ao comércio internacional.

\footnotetext{
${ }^{1}$ Perrone-Moises, 1998, p. 69.

${ }^{2}$ Celli Jr., 2005, p. 143.

${ }^{3}$ E/CN.4/2000/WG.18/CRP.1, de 11 de setembro de 2000.
} 
Sobre as relações entre o comércio internacional de serviços $\mathrm{e} o$ direito ao desenvolvimento, em relatório do Alto Comissariado sobre Direitos Humanos, o Conselho Econômico Social da ONU atestou que a liberalização do comércio em vários setores de serviços é relevante para a realização dos direitos humanos e que quaisquer compromissos assumidos nos setores da saúde, educação ou meio ambiente podem afetar a realização do direito à saúde, à educação e do direito ao desenvolvimento ${ }^{4}$.

Um estudo da Organização para a Cooperação e Desenvolvimento Econômico (OCDE) atestou as falácias do GATS no setor educacional como sistema de apoio ao desenvolvimento ${ }^{5}$.

Alguns pesquisadores já têm desenvolvido seus estudos sobre o setor de serviços educacionais em que discorrem sobre os efeitos da liberalização para o desenvolvimento. Etiane Primo ressalta que "a função essencial da educação, além de proporcionar crescimento econômico, é reduzir o déficit social", E ainda lembra que "se por um lado uma liberalização irrestrita na área de educação pode acarretar conseqüências ainda inimagináveis; de outro, não há dúvidas de que o atual modelo adotado por muitos dos países membros tem excluído significativa parcela de sua população desta garantia social fundamental"

Pelos motivos expostos e manifestações acima, não resta dúvidas de que os temas objetos do presente estudo têm sido tratados na doutrina e nos fóruns internacionais que discutem comércio e direitos humanos.

Destaca-se, ainda, que a efetividade do direito ao desenvolvimento está condicionada ao funcionamento do sistema econômico, político e social vigente no plano internacional ${ }^{8}$. Além disso, a participação de um Estado dentro desse sistema econômico e político é fundamental para o desenvolvimento dos países e as condições do sistema vigente, na prática, não permitem uma ascensão e crescimento dos países em desenvolvimento, sendo necessária uma cooperação com países desenvolvidos a fim de possibilitar maiores condições de desenvolvimento.

\footnotetext{
${ }^{4} \mathrm{ONU}, \mathrm{E} / \mathrm{CN} .4 / \mathrm{Sub} .2 / 2002 / 9$, de 25 de junho de 2002: "The liberalization of trade in several service sectors is relevant to the enjoyment of human rights. Most directly, any commitments in the health, education or environmental sectors can affect the enjoyment of the right to health, the right to education and the right to development".

${ }^{5}$ Sauvé, 2002.

${ }^{6}$ Primo, 2005, p. 291.

${ }^{7}$ Primo, 2005, p. 290.
} 
Assim, a idéia de um comércio internacional que contribua para a realização de direitos humanos não se resume apenas à inexistência de prejuízos à realização desses direitos. Um sistema de comércio internacional favorável ao desenvolvimento e aos direitos humanos deve ir além, pois deve alcançar efetivos benefícios e melhorias para o desenvolvimento econômico dos países e para a garantia e proteção dos direitos humanos a todos os indivíduos.

O comércio internacional de serviços educacionais, portanto, como parte desse sistema multilateral de comércio, também deverá estar inserido nessa lógica de cooperação e solidariedade internacional. Assim, é fundamental que se procure encontrar coerência para a ordem econômica e social internacional, por meio de uma verdadeira aproximação do direito ao desenvolvimento às regras do comércio internacional de serviços educacionais.

Só assim será possível incorporar a visão kantiana, de que trata Perrone-Moisés ${ }^{9}$, ao campo das relações econômicas, que deve considerar a inserção dos valores humanos no estabelecimento da regulamentação econômica internacional, a fim de buscar efetivas melhorias nas condições da Humanidade.

\footnotetext{
${ }^{8}$ Oliveira, 2005, p. 504.

${ }^{9}$ Perrone-Moisés, 1999, p. XV-XVI.
} 


\section{I - COMÉRCIO, DESENVOLVIMENTO E DIREITOS HUMANOS}

O debate sobre a relação entre o comércio internacional, os direitos humanos e o desenvolvimento não é de hoje. Há algum tempo a comunidade internacional despertou-se para os impactos da globalização e da conseqüente aproximação comercial entre os países no desenvolvimento e na realização e proteção dos direitos humanos.

A relação entre o comércio internacional e o desenvolvimento é evidente. Não há dúvidas, portanto, de que é preciso cautela na condução das negociações comerciais para que o comércio de fato contribua para o desenvolvimento dos países envolvidos nas relações internacionais. Mais do que uma preocupação com o desenvolvimento econômico, o fato é que o resultado das negociações comerciais pode influenciar e, em geral, influencia o desenvolvimento dos indivíduos também. Nesse sentido, a abertura indiscriminada dos mercados já se mostrou ineficiente para a sustentabilidade do comércio e inapropriada para a promoção e proteção dos direitos humanos. Apesar de uma atual agenda pelo desenvolvimento na OMC, ainda são fortes as pressões por decisões favoráveis apenas a um ou outro grupo e que não levam em consideração as demandas do desenvolvimento e dos direitos humanos.

O comércio internacional, portanto, é visto hoje como peça fundamental para o desenvolvimento de um país e fator de influência em diversas outras áreas de direito interno e internacional, tal como a proteção dos direitos humanos. Notou-se que a participação no comércio internacional e as negociações comerciais influenciavam de forma relevante a proteção dos direitos humanos e sua garantia a todos os indivíduos.

Já é sabido que, na atual conjuntura, nenhum Estado pode prescindir de relações com outras nações, em especial no que tange às relações comerciais. Ocorre que o processo de aproximação entre os países não aconteceu, como se sabe, de forma eqüitativa e atualmente vive-se um cenário de desigualdades sociais e econômicas entre os países. Essas desigualdades refletem uma situação em que predominam modelos de dominação e dependência nas relações comerciais internacionais ${ }^{10}$, marcadas pela concentração do poder econômico nas mãos dos países desenvolvidos, que por meio da atuação de suas empresas privadas transnacionais, conseguem manter a hegemonia no comércio internacional. Essas discrepâncias acarretaram, em pouco tempo, as dificuldades de alguns

\footnotetext{
${ }^{10}$ Perrone-Moisés, 1999, p. 191.
} 
países desenvolverem-se internamente e impediram conseqüentemente, o avanço dos direitos humanos no plano interno desses países menos desenvolvidos.

É bem verdade que a impossibilidade de um desenvolvimento econômico e social interno ideal não pode ser alegada como justificativa para que um Estado deixe de garantir e proteger os direitos humanos, tarefa com a qual todos devem estar comprometidos por serem partes de uma comunidade internacional. No entanto, não se pode olvidar que um maior desenvolvimento dos países deverá contribuir inevitavelmente para maiores possibilidades de realização de diversos direitos humanos. Por este motivo, o tema do desenvolvimento sócio-econômico dos Estados menos desenvolvidos é tratado como uma das maiores preocupações internacionais da atualidade ${ }^{11}$.

Dessa forma, as relações econômicas e comerciais entre os países passaram a ser analisadas de forma mais crítica, uma vez que a participação efetiva de um Estado nas relações internacionais funciona como importante ferramenta para o desenvolvimento interno deste país e, conseqüentemente, para a garantia dos direitos humanos.

A cooperação internacional nas negociações comerciais tornou-se, dessa forma, ainda mais importante para a eficácia dos direitos humanos ${ }^{12}$. Isso porque todos os Estados têm a obrigação de proteger e garantir a aplicação dos direitos fundamentais, mas para países em desenvolvimento e de menor desenvolvimento relativo, essa obrigação é ainda mais difícil de ser realizada e, portanto, evidentemente necessária é a contribuição dos países desenvolvidos no cumprimento desta "tarefa". Essa obrigação necessária de cooperar pela realização dos direitos humanos justifica-se exatamente pelo fato de serem direitos de indivíduos. Isso significa que não se trata de defender os direitos deste ou outro Estado de se desenvolver economicamente, mas trata-se de proteger todos os seres humanos.

\footnotetext{
${ }^{11}$ A criação da Conferência das Nações Unidas sobre Comércio e Desenvolvimento (UNCTAD) como órgão da ONU, responsável por servir como fórum de debate sobre os impactos do comércio internacional para o desenvolvimento dos países e indivíduos atesta essa preocupação da comunidade internacional com o relacionamento entre comércio e países em desenvolvimento. Isso porque este órgão, como se verá adiante, nasce de reivindicações dos países em desenvolvimento por maiores participações no comércio internacional auxílio para o desenvolvimento. Ainda que a atuação da UNCTAD não venha tendo tanta força quanto se almejaria inicialmente, trata-se de importante manifestação desse posicionamento novo que busca condicionar a economia aos objetivos dos direitos humanos.

${ }^{12}$ Nesse sentido, a Carta da ONU, em seu capítulo IX sobre Cooperação Internacional Econômica e Social, prevê no artigo 55 que: "Com o fim de criar condições de estabilidade e bem estar, necessárias às relações pacíficas e amistosas entre as Nações, baseadas no respeito ao princípio da igualdade de direitos e na autodeterminação dos povos, as Nações Unidas favorecerão: a) níveis mais altos de vida, trabalho efetivo e condições de progresso e desenvolvimento econômico e social; b) a solução de problemas internacionais econômicos, sociais, sanitários e conexos; a cooperação internacionais, de caráter cultural e educacional; $e$ c) o respeito universal e efetivo dos direitos humanos e das liberdades fundamentais para todos, sem distinção de raça, sexo, língua ou religião."
} 
É fato, porém, que:

(...) dada a fluidez do processo de crescimento econômico e de mudança (que dificulta construir mecanismos de regulação) num ambiente internacional anárquico (em que se valoriza o exercício da soberania), a opção tem sido deixar o comportamento dos atores e dos fluxos das transações econômicas internacionais para a ação do mercado, ainda que muito a contragosto, na maioria das vezes. ${ }^{13}$

Isso porque, em um cenário, em que predomina a ordem liberal, o comércio tende a ser visto como peça chave do processo de crescimento, ainda que presente a concepção de que o Estado tem um papel fundamental na regulamentação das relações econômicas.

A análise abaixo trata da evolução do conceito de crescimento econômico e da sua relação com o desenvolvimento econômico, além de apresentar um breve histórico da relação entre a liberalização comercial e os conceitos anteriores, para posteriormente, apresentar a relação entre o comércio e os direitos humanos.

\subsection{LIBERALIZAÇÃO, CRESCIMENTO ECONÔMICO E DESENVOLVIMENTO}

É enorme o debate sobre as vantagens e desvantagens da liberalização comercial para o desenvolvimento das nações e dos indivíduos, sendo diversas as posições sobre o assunto.

É bem verdade que essas opiniões variam bastante, exatamente porque os fatos e a experiência demonstram que a liberalização pode ser mais ou menos vantajosa ao desenvolvimento, dependendo do entendimento que se tem sobre o conteúdo deste último conceito.

Assim, é fato que, segundo dados e análises compilados a partir de indicadores objetivos de renda e participação no comércio internacional, os países que apresentam uma maior participação do comércio exterior na formação do PIB, ou que ostentam, de maneira geral, um maior grau de abertura econômica (fluxos de capitais, investimentos diretos etc.), apresentam uma renda média superior a 23 mil dólares, ao passo que aqueles países caracterizados por uma economia mais fechada aos intercâmbios globais, exibem 3.800 dólares como renda per capita ${ }^{14}$.

De fato, o comércio internacional possui inúmeros benefícios: "os países menos integrados à economia global restringem as opções de consumo da população, possuem um parque

\footnotetext{
${ }^{13}$ Sato, 2004, p. 56.

${ }^{14}$ De Almeida, 2004, p. 21.
} 
industrial completamente estagnado, não dispõem de recursos para investir em tecnologia nem escala para produzir bens de maior valor agregado" $"$.

Da mesma forma, Joseph Stiglitz ${ }^{16}$ explica que:

A abertura comercial internacional ajudou vários países a crescer muito mais rapidamente do que teriam crescido sem essa abertura. O comércio internacional ajuda o desenvolvimento econômico quando as exportações de um país impulsionam seu crescimento econômico. As exportações conduziram a um crescimento que é a peça central da política industrial que enriqueceu grande parte da Ásia e deu a milhões de indivíduos condições de vida muito mais confortáveis. Graças à globalização, a expectativa de vida em todo o mundo aumentou bastante, e o padrão de vida melhorou muito.

Conclui-se, conforme Roberto Di Sena Jr. ${ }^{17}$, que o comércio internacional favorece, de fato, um maior acesso dos consumidores a um número maior de bens, estimula a competitividade, provocando uma melhoria na qualidade dos produtos e uma queda nos seus preços, favorece ainda a melhor alocação de capital e mão-de-obra dentro dos países e elimina distorções de produção e consumo, além de contribuir para a redução das distâncias geográficas e culturais entre os países.

Há, portanto, evidências de que uma maior abertura comercial deve contribuir para o crescimento econômico interno dos países. No entanto, essas evidências não relatam de que forma a renda é distribuída, se há, de fato, uma diminuição da pobreza no país, entre outros aspectos não diretamente relacionados ao crescimento econômico, mas que hoje, são fatores fundamentais para a determinação do nível de desenvolvimento de um país.

Como bem destaca Arvind Panagariya ${ }^{18}$, a abertura comercial promove o crescimento de diversas formas, permitindo maior acesso a novas tecnologias e uma maior especialização dos países naquilo que produzem melhor. No entanto, essa abertura, por si só, não é suficiente para promover o desenvolvimento. É necessário que haja estabilidade política e macroeconômica, bem como outras políticas públicas para garantir que a liberalização, como principal expressão da globalização, gere efetivos benefícios para os Estados.

Percebe-se, portanto, que os efeitos da abertura comercial são dúbios e contraditórios conforme mesmo toda forma de expressão do processo de globalização. Isso porque a

\footnotetext{
${ }^{15}$ Di Sena Jr., 2004, p. 62

${ }^{16}$ Stiglitz, 2002, p.30.

${ }^{17}$ Di Sena Jr., 2004, p. 63.

${ }^{18}$ Panagariya, 2003, p. 1.
} 
liberalização pode trazer benefícios e malefícios simultaneamente, dependendo da variável sobre a qual incidem os seus efeitos.

Dessa forma, para entender as vantagens e desvantagens da liberalização comercial, é fundamental que, inicialmente, se diferencie o significado dos termos "crescimento econômico" e "desenvolvimento", para entendê-los como dois aspectos distintos que sofrem os impactos do comércio internacional ${ }^{19}$.

Para compreender melhor o conceito de crescimento econômico, é relevante entender a sua relação com a noção de ordem econômica internacional, já que o crescimento possui papel fundamental para a sustentação de qualquer ordem econômica que se pretende instituir ou manter no plano internacional.

A idéia de uma ordem econômica internacional parte do princípio de que as relações econômicas internacionais - que englobam uma série de transações distribuídas pelas áreas financeira, monetária e comercial - não são eventos completamente aleatórios e imprevisíveis, mas carregam também, como qualquer fenômeno social, uma dose de articulação e previsibilidade ${ }^{20}$. Essa possibilidade de se prever como as relações econômicas se articulam é que permite estabelecer uma ordem econômica internacional.

Dessa forma,

quando se fala de ordem econômica internacional, tem-se em mente que as transações econômicas levadas a efeito entre agentes situados em diferentes países obedecem a alguma forma de ordenamento social, isto é, essas transações não são neutras e aleatórias, mas atendem a interesses e visões de ganhos que vão além da busca de resultados meramente econômicos. ${ }^{21}$

Assim, é possível dizer que as relações internacionais não são neutras, mas possuem sentido e direção coerentes com e guiados pelas forças presentes e atuantes no cenário internacional. Isso significa dizer que a ordem econômica internacional é, em geral, transitória, vez que os interesses e os objetivos dos atores internacionais costumam mudar diante das alterações nas estruturas sociais, do surgimento de novas tecnologias, das alterações no poder político internacional, entre outros fatores determinantes para a manutenção ou erosão de determinada ordem econômica internacional.

\footnotetext{
${ }^{19}$ Ressalte-se que o termo "desenvolvimento" neste primeiro capítulo será entendido como um conceito diferenciado do crescimento econômico, porém, somente no próximo capítulo este termo será analisado pormenorizadamente para fazer constar diversas concepções que existem sobre seu conteúdo.

${ }^{20}$ Sato, 2004, p. 35.

${ }^{21}$ Sato, 2004, p. 35.
} 
É por este motivo que, “dependendo das características das economias mais poderosas, a ordem econômica internacional tende a estruturar-se de acordo com certas regras $e$ condições" $^{\text {"22 }}$. É fato que são as grandes potências do momento que acabam determinando como a ordem econômica internacional daquele momento deve ser estabelecida, já que são essas potências que arcam com o ônus de sua manutenção. Dessa forma, é natural que exijam em troca, que esta ordem atenda a seus interesses essenciais.

Assim, é fácil afirmar que as alterações no quadro de valores políticos de uma época ou mudanças na estrutura de poder da sociedade internacional quase sempre ensejarão alterações na ordem econômica internacional.

Apresentada a noção de ordem econômica internacional, é possível analisar o papel do crescimento econômico dentro da lógica da sua manutenção.

Apesar das mudanças entre uma ordem econômica internacional e outra, é fato que a busca pelo crescimento econômico é, de certa forma, uma constante. As instituições e políticas de determinada ordem econômica internacional são guiadas pela lógica da estratégia de crescimento econômico.

O crescimento econômico tem ocupado sempre um papel central entre as preocupações dos principais economistas. São vários os fatores para que o crescimento ocupe essa posição, entre eles o simples fato do exponencial crescimento populacional exigir o aumento da oferta de bens e serviços. Mas, além disso, o desejo de ascensão social e a busca por uma maior obtenção de poder entre grupos sociais e nações também são determinantes para que o crescimento econômico seja um objetivo fundamental de uma ordem econômica internacional.

Ademais, o Estado depende, por diversos motivos, do crescimento econômico para o cumprimento de seus fins, "já que tanto os requisitos da segurança quanto as demandas por serviços públicos básicos só podem ser adequadamente atendidos por uma crescente soma de recursos" 23 .

Percebe-se, portanto, que as pressões pelo crescimento econômico são diversas, sendo que, quando não atendidas, podem desestabilizar as instituições políticas e sociais estabelecidas em determinada ordem econômica social.

\footnotetext{
${ }^{22}$ Sato, 2004, p. 41

${ }^{23}$ Sato, 2004, p. 43.
} 
Dessa forma, pode-se dizer que a estratégia de crescimento econômico se reflete nas instituições e práticas vigentes no comércio, no padrão monetário e no regime financeiro que caracterizam a ordem econômica vigente ${ }^{24}$. Assim, o comércio internacional tem como principal objetivo o crescimento econômico e só se pode manter sua estrutura se atendido esse requisito.

Nesta lógica, acaba por criar-se uma relação reflexa entre a ordem econômica vigente e o crescimento econômico, sendo que um existe para sustentar o outro. O objetivo da ordem econômica é alcançar maior crescimento econômico para que possa ser mantida como ordem vigente.

Daí porque se convencionou acreditar que o comércio internacional sempre fora capaz de gerar crescimento econômico (vez que o comércio é um das formas encontradas pela ordem internacional para alcançar o crescimento e, conseqüentemente, manter-se). Ocorre que a própria realização do crescimento gera, inevitavelmente, mudanças tecnológicas, políticas e sociais que demandam novas alterações na ordem econômica internacional. Essas vicissitudes, por sua vez, fazem com que o conceito de crescimento econômico, aos poucos, passe a englobar novas necessidades.

O desejo de ascensão social, a busca por melhores padrões de consumo (incluindo-se aí o acesso a bens e serviços como aqueles relacionados à saúde, à educação, à seguridade social e à cultura) e a demanda por empregos podem assumir inúmeras formas de pressão sobre a ordem econômica: demanda por novos empregos e por melhorias salariais, disputa por mercados por parte de novos produtores, democratização do acesso a bens de consumo, desejo de acesso a símbolos de reconhecimento social, desenvolvimento de novas tecnologias etc ${ }^{25}$.

Assim, o crescimento econômico, entendido como incremento das riquezas de uma nação, não é mais capaz, por si só, de atender a todas as "novas" demandas da sociedade, sendo que, aos poucos, esse conceito seco e mais delimitado passa a ser ampliado, aproximandose, cada vez mais de uma nova concepção, até então entendida como sinônimo do crescimento: o "desenvolvimento" 26 .

\footnotetext{
${ }^{24}$ Sato, 2004, p. 47.

${ }^{25}$ Sen, 2000, p. 17 e 18.

${ }^{26}$ Neste momento, ainda trata-se de desenvolvimento econômico, sem adentrar ainda nas diversas noções do conceito de desenvolvimento, o que será feito adiante.
} 
Passou-se a se considerar que o crescimento permanece como um componente de vital importância no processo de desenvolvimento, porém, reconhece-se ao mesmo tempo, que o desenvolvimento não se esgota no mero crescimento econômico.

No entanto, os efeitos do comércio internacional não deixaram de ser relevantes para o estudo do desenvolvimento. Isso porque, a associação entre a liberalização e o crescimento permaneceu clara, de forma que ainda se entende que a abertura comercial gera crescimento. E o crescimento também permanece como fator relevante do desenvolvimento.

A partir de então, passa-se a avaliar a relação entre o comércio internacional e o desenvolvimento, com vistas não só ao crescimento econômico, mas em atenção a um conceito mais amplo, que avalia ainda outras variáveis, como distribuição de renda, diminuição da pobreza, geração de empregos, etc.

O Professor Calixto Salomão Filho ${ }^{27}$ faz uma breve análise histórica do papel do comércio internacional para os Estados como propulsor do desenvolvimento interno. Nessa avaliação, relembra que desde a Antigüidade, são conhecidas passagens que dão conta da importância estratégica do comércio com as colônias.

Esse tratamento do comércio internacional como questão de Estado, relevante para o bem estar e o desenvolvimento de cada nação, permanece constante na Idade Média, quando o comércio e a produção para o comércio são verdadeiros propulsores do desenvolvimento das Cidades-Estado, chegando-se ao mercantilismo, em que o comércio internacional torna-se a razão de ser do próprio Estado.

O professor ainda ressalta que mesmo a Revolução Industrial, entendida como movimento econômico que vê na mudança do estado da técnica produtiva o principal fator de desenvolvimento econômico, só se estabelece como padrão econômico mundial, quando a Inglaterra se consolida como potência hegemônica no comércio internacional. Este país, a partir de então, passa a se aproveitar da sua vantagem relativa em matéria de evolução das técnicas de produção para obter os maiores ganhos no comércio internacional, o que dá grande impulso ao desenvolvimento interno desta nação.

${ }^{27}$ Salomão Filho, 2003, p. 535. 
Note-se que é justamente o fato de possuir uma vantagem relativa no comércio internacional que permite à Inglaterra manter-se à frente dos demais Estados em termos de desenvolvimento econômico interno.

A partir de então, afirma Calixto Salomão Filho ${ }^{28}$ que:

(...) todos os casos vitoriosos de desenvolvimento econômico derivaram (ao menos no momento inicial) de circunstâncias excepcionais ou da criação de um fortíssimo mercado interno decorrente de circunstâncias históricas específicas (como é o caso dos EUA no final do século XIX) ou de imensas subvenções estatais ou internacionais para o desenvolvimento (como é o caso da Alemanha e do Japão no imediato pós-guerra). Dado o passo inicial, essas nações brevemente se ombrearão à Inglaterra e França na dianteira do desenvolvimento industrial, podendo então também se beneficiar do comércio internacional.

O comércio internacional passa a ser, dessa forma, um instrumento propulsor de desenvolvimento econômico apenas para aquelas nações que possuem vantagens relativas capazes de garantir uma posição privilegiada de seus produtos e serviços no comércio internacional.

A partir de então, o descontentamento dos países em desenvolvimento, insatisfeitos com a ausência de vantagens decorrentes de sua participação no comércio internacional, seguido pela crise da energia dos anos 1970 (que tornou essas insatisfações em verdadeira crise generalizada) e culminando com a crise do endividamento dos países do terceiro mundo dos anos 1980, contribuiu de forma decisiva para alterar a percepção do significado da cooperação internacional para o desenvolvimento contido nas estratégias de ação das instituições de fomento (em especial, o Banco Mundial), que passaram a sofrer alterações relevantes, reorientando suas prioridades para passar a contemplar principalmente projetos voltados para áreas como a promoção da saúde pública, a recuperação e preservação de recursos ambientais e a proteção e promoção de minorias, e tornando evidente que a estratégia de crescimento econômico havia se esgotado.

Ressalte-se que o "surgimento" da globalização realça novamente a importância do comércio internacional, diante da renovada e avançada rede de interdependência a que passam a estar vinculados os Estados.

No entanto, essa necessidade de inter-relação dos Estados torna mais evidente ainda a presença das desigualdades econômicas, sociais e políticas que separam os países, os quais, apesar disso, dependem uns dos outros na lógica da globalização. Essa clareza quanto às 
diferenças no desenvolvimento das nações faz crescer a insatisfação dos países menos desenvolvidos, que buscam cada vez mais espaço nas relações comerciais internacionais para enfrentar as desvantagens trazidas pelo processo de globalização ${ }^{29}$ e, para tanto, exigem novos conceitos e novas regras, que reflitam as mudanças de posicionamento quanto ao conceito de crescimento econômico e de desenvolvimento.

A evolução histórica mostra, portanto, que o comércio internacional sempre foi importante instrumento gerador de desenvolvimento econômico interno. No entanto, as alterações na ordem econômica internacional, as diferenças históricas de evolução dos países e o aumento da importância das relações internacionais levaram alguns países a fortalecer seus mercados internos a ponto de possuírem vantagens comparativas altamente relevantes no comércio internacional.

Essa situação de desigualdades entre os participantes das relações comerciais internacionais tornou fraca a idéia de que o comércio internacional sempre gera automaticamente desenvolvimento econômico, já que a maioria dos países sempre perderá espaço no mercado internacional para os produtos das hegemonias econômicas.

O comércio internacional deixa, então, de ser instrumento de desenvolvimento, ainda que não por sua ineficácia, mas porque diversas nações (EUA, Japão, Alemanha) por circunstâncias históricas diversas, conseguem nele prevalecer. $\mathrm{O}$ comércio internacional torna-se instrumento de desenvolvimento para alguns e de subdesenvolvimento para outro, sendo, portanto, uma fonte importante de desequilíbrios regionais. ${ }^{30}$

Conclui-se, portanto, que, no atual cenário das relações internacionais, a participação no comércio nem sempre acarretará desenvolvimento econômico para uma nação. Dessa forma, a liberalização do comércio (seja ela em qualquer setor) não pode ser realizada sem a imposição de condições que permitam que ela gere desenvolvimento a todos os países participantes do comércio internacional. Deixou-se de entender o comércio como a chave ou o motor capaz de empurrar o crescimento.

Todo este novo cenário, que passa a dificultar a promoção da liberalização irrestrita, coloca também em xeque a importância do crescimento econômico para o desenvolvimento das

\footnotetext{
${ }^{28}$ Salomão Filho, 2003, p. 536.

${ }^{29}$ Ressalte-se que, apesar das desvantagens da globalização, é o aprofundamento deste processo que abre espaço para maior atuação dos países em desenvolvimento no cenário internacional, que, por sua vez, permite que as reivindicações e exigências por maior justiça nas relações internacionais recebam maior atenção da comunidade internacional.

${ }^{30}$ Salomão Filho, 2003, p. 537.
} 
nações. Torna-se mais forte a idéia de que uma liberalização do comércio ainda vinculada prioritariamente à estratégia de crescimento econômico não merece prosperar.

Ainda nessa discussão, o Professor Welber Barral bem atesta que "o comércio internacional pode ser instrumento estratégico para o desenvolvimento. O sucesso de sua utilização, entretanto, dependerá de fatores institucionais e sociais que não são inerentes nem derivados das práticas comerciais" 31 .

Assim, conclui Barral que, para se construir um modelo analítico da relação entre o comércio internacional e o desenvolvimento, é necessário considerar-se a existência de variáveis mínimas que influenciarão essa relação. Além disso, deve-se definir ainda o conceito de desenvolvimento aplicado nesta análise.

Afirma, portanto, o professor que, no mínimo, sete variáveis deverão ser consideradas no processo de análise da relação entre comércio e desenvolvimento, quais sejam:

a) o momento histórico do país analisado e do cenário internacional, que afeta diretamente a relevância que os fluxos comerciais podem obter em relação à economia nacional; b) a localização geográfica, pois, embora a evolução dos transportes o tenha minimizado, este fator ainda é relevante quando se considera a proximidade dos mercados consumidores; c) a dimensão do país em questão e sua capacidade de produção autônoma de recursos necessários ao desenvolvimento econômico; d) a dimensão e equilíbrio do mercado consumidor, que implicará possibilidades de ganhos de escala; e) a infra-estrutura e sua adaptabilidade ao comércio internacional; f) a estrutura institucional e seus custos para o funcionamento da ordem econômica como um todo e para a competitividade do país; g) os interesses políticos relacionados ao comércio, seja em termos de extensão do poder nacional, seja em termos de temor da dependência de uma potência maior. $^{32}$

Além da análise das variáveis, o entendimento sobre o que é "desenvolvimento" também deverá influenciar a avaliação dos impactos do comércio internacional no desenvolvimento ${ }^{33}$.

A doutrina que defende as vantagens da liberalização do comércio obviamente acredita que o comércio internacional é positivo para o desenvolvimento, por entender que desenvolvimento equivale a crescimento econômico. Essa foi a teoria adotada durante

\footnotetext{
${ }^{31}$ Barral, 2006, p. 12.

32 Barral, 2006, p. 13.

${ }^{33}$ Já neste capítulo, fica claro que o conceito de desenvolvimento aplicado neste trabalho não é restrito à concepção de desenvolvimento econômico. Ao contrário, desenvolvimento aqui é entendido como um conceito amplo, que engloba diversos fatores, que deverão ser medidos a fim de se afirmar o grau de desenvolvimento de um país. A evolução histórica deste conceito será analisada no próximo capítulo, em que ficará clara a idéia de um desenvolvimento como direito humano individual e coletivo.
} 
muito tempo, acompanhando historicamente o conceito de desenvolvimento. É somente nos últimos anos que aspectos sociais e humanos vêm sendo inseridos neste conceito.

Dessa forma, passa-se a pressupor que outros elementos, igualmente relevantes ao crescimento econômico, também são relacionados como sofrendo o impacto do comércio internacional, tais como: o desenvolvimento econômico, a redução da pobreza e da discriminação, a evolução institucional, o desenvolvimento social e desenvolvimento sustentável, o que torna a relação entre comércio e desenvolvimento muito mais complexa.

Vê-se, portanto, que a construção de um modelo meramente econométrico, que vise a medir o impacto do comércio no desenvolvimento simplesmente por meio da avaliação dos números relativos ao crescimento econômico do país, não traz um resultado real, ainda que possa tangenciá-lo, pois para avaliar os impactos reais do comércio no desenvolvimento interno de um país, é necessário avaliar as condições das referidas variáveis nesta nação.

A conclusão, novamente, é de que, para um conceito contemporâneo de desenvolvimento, que abrange outros elementos além do crescimento econômico, a liberalização do comércio tem efeitos ambíguos.

Isso porque pode-se afirmar que não há uma correlação direta e inarredável entre comércio e desenvolvimento, ao contrário do que veementemente se repetiu nas décadas passadas. Sabe-se que se a abertura comercial, em determinadas situações particulares, pode ser uma estratégia viável de promoção ao desenvolvimento, esta não é uma premissa que necessariamente possa ser estendida indistintamente a todo o mundo em desenvolvimento.

Dessa forma, a comunidade internacional deve passar a se preocupar sobre a forma pela qual a liberalização comercial se efetiva. O objetivo, portanto, é buscar uma maneira de fazer com que o comércio internacional efetivamente seja um instrumento para um projeto nacional de desenvolvimento. Para tanto, é necessário refutar a visão do comércio como um fim em si mesmo.

Essa idéia de que o comércio internacional pode trazer não só impactos positivos aos países, mas também pode efetivamente prejudicar o desenvolvimento de países mais pobres, fez com que os países em desenvolvimento, preocupados com a dominação dos países ricos na OMC e interessados em fazer de sua participação no comércio internacional 
algo benéfico ao seu desenvolvimento interno, passassem a reivindicar melhorias no sistema multilateral do comércio ${ }^{34}$.

Bem lembra Silvia Menicucci de Oliveira que:

os países em desenvolvimento estavam, desse modo, diante de um sistema econômico internacional organizado por uma minoria, que não refletia as necessidades específicas e baseado na igualdade formal dos atores envolvidos. Logo, reivindicaram mudanças dos fundamentos das relações comerciais internacionais que tornavam necessárias alterações e inovações dos institutos e instrumentos jurídicos pertinentes ao assunto, contestando as regras então vigentes ${ }^{35}$.

Essas reivindicações, resultantes da importância dada à participação no comércio internacional para o desenvolvimento econômico e social, levaram a uma busca dos países em desenvolvimento por um fórum especializado na análise das vantagens e desvantagens do comércio internacional para o desenvolvimento, a fim de pressionar as nações desenvolvidas por meio da comunidade internacional., o que levou à criação da Conferência das Nações Unidas para Comércio e Desenvolvimento, que ficou mais conhecida no Brasil por sua sigla em inglês, UNCTAD (United Nations Conference on Trade and Development).

Foi diante dessa necessidade de se buscar um fórum para aproximar as questões de comércio internacional e de desenvolvimento que a $\mathrm{ONU}^{36}$ decidiu estabelecer a UNCTAD, em dezembro de 1964. A essa época estava vigente o GATT como acordo regulador das relações comerciais internacionais no âmbito multilateral. Ainda não existia a OMC e o GATT (cuja estrutura era de 1947) estava restrito às questões de comércio e tarifa de bens apenas, não permitindo o debate sobre a questão do desenvolvimento e das desigualdades econômicas entre os países contratantes do acordo.

\footnotetext{
34 Fala-se na existência à época do final da segunda Guerra Mundial, de conflitos de concepção em contraposição aos conflitos de interesses, caracterizada pela prevalência de polaridades. Os conflitos de concepção estariam ligados aos valores ideológicos, sobre diferentes visões de como promover interesses ou solucionar problemas. Não são conflitos resolvidos por meio de negociações de interesses. A existência dessa variedade de opiniões contribuiu para o surgimento da idéia do desenvolvimentismo, ou seja, da preocupação com o reflexo do mercado e da economia no social e político dos países. Dessa forma, contribuiu também para o aumento das preocupações com a ligação do comércio internacional e o desenvolvimento. Sobre os conflitos de concepção e de interesse, ver Lafer, 1999.

${ }^{35}$ Oliveira, 2003, pp. 97-98.

${ }^{36}$ Vale lembrar que durante a década de 60, a ONU vivenciou um aumento expressivo no número de Estados membros, com a adesão dos novos Estados independentes, principalmente nos continentes africano e asiático, a partir do movimento de descolonização. Essas novas nações independentes, muito marcadas pela recente condição de colônia, deram à ONU uma nova dimensão e trouxeram a discussão sobre a auto-determinação dos povos e o debate sobre a independência econômica, que também contribuiu para o crescimento do debate sobre o desenvolvimento econômico e a necessidade de sobrevivência dos novos Estados.
} 
O preâmbulo da Resolução da ONU que cria a UNCTAD como órgão subsidiário da Assembléia Geral da organização registra a preocupação com a participação dos países em desenvolvimento no comércio internacional e a importância deste no desenvolvimento interno dos países, reconhecendo também a necessidade de a comunidade internacional buscar esforços para o crescimento econômico dos países em desenvolvimento:

\section{A Assembléia Geral,}

Convencida de que são necessários esforços para elevar os padrões de vida em todos os países e para acelerar o crescimento econômico dos países em desenvolvimento,

Considerando que o comércio internacional é um instrumento importante para o desenvolvimento econômico,

(...)

Cria a Conferência das Nações Unidas para o Comércio e o Desenvolvimento $(\ldots)^{37}$.

Dessa forma, apesar de ter sido criada como órgão da ONU, a UNCTAD surgiu como esperança de transformar-se em uma nova organização internacional que viesse a regular o comércio internacional com vistas à promoção do desenvolvimento econômico, em especial dos países em desenvolvimento.

Não obstante esse desejo dos países em desenvolvimento em tornar a UNCTAD uma nova organização internacional do comércio ${ }^{38}$ e do desenvolvimento, a UNCTAD nunca chegou a se transformar juridicamente em uma organização internacional, cedendo às pressões dos países desenvolvidos. As expectativas de que este órgão viesse a ser a principal organização internacional do comércio foram praticamente exterminadas com a criação da OMC, em 1994.

Importante ainda lembrar que as discussões sobre a necessidade desse novo fórum do comércio e desenvolvimento receberam enorme contribuição dos trabalhos de Raúl Prebisch, responsável pela criação da Comissão Econômica para a América Latina e o Caribe (CEPAL), em 1948, que visava contribuir para o desenvolvimento econômico de forma regionalizada e já atestava a necessidade de aproximação entre os temas do comércio internacional e do desenvolvimento, reconhecendo a importância do comércio

\footnotetext{
${ }^{37}$ Resolução da Assembléia Geral da ONU n. 1995 (XIX). Tradução livre de:

"The General Assembly,

Convinced that sustained efforts are necessary to raise standards of living in all countries and to accelerate the economic growth of the developing countries,

Considering that international trade is an important instrument for economic development, (...)

Establishes the United Nations Conference on Trade and Development (...).”

38 O Preâmbulo da Resolução 1995 (XIX) lembra o desejo geral entre os países em desenvolvimento de se constituir uma organização o mais abrangente possível para o comércio ("the widespread desire among developing countries for a comprehensive trade organization").
} 
para o desenvolvimento econômico e social dos países latino-americanos. Por este motivo, Raul Prebisch assumiu o primeiro mandato de Secretário Geral da UNCTAD, o que registra a importante contribuição do pensamento econômico da América Latina no cenário internacional.

Vê-se que a UNCTAD surgiu como uma resposta positiva às reivindicações dos países em desenvolvimento, em uma época em que os interesses dos países desenvolvidos eram defendidos por uma minoria poderosa, que não pensava em discutir questões que fossem além das leis de mercado quando se tratava de comércio internacional.

Ainda que atualmente os países desenvolvidos continuem a impor seus interesses e a procurar burlar as regras que, em tese, beneficiariam os países em desenvolvimento, a discussão sobre o desenvolvimento, os direitos humanos e a justiça social de forma internacional, permanece constante e presente, não apenas na UNCTAD, mas espalhada por todas as organizações internacionais, não-governamentais e nos próprios governos dos Estados.

A UNCTAD, portanto, teve papel fundamental ao chamar a atenção da comunidade internacional para o problema do desenvolvimento e sua importância na busca pelo ideal de justiça nas relações internacionais, uma vez que se baseou em princípios de igualdade efetiva entre os países, que apresentavam e ainda apresentam tantas especificidades e diferenças uns com os outros.

É inegável, portanto, que o comércio internacional não pode estar afastado das discussões sobre o desenvolvimento e de medidas que diminuam as discrepâncias econômico-sociais entre os países desenvolvidos, os países em desenvolvimento e os de menor desenvolvimento relativo.

Posteriormente, a própria criação da OMC pode ser vista como o início de uma mudança no posicionamento da comunidade internacional quanto aos efeitos do comércio internacional para o desenvolvimento. A criação de uma organização internacional, muito mais abrangente que o GATT, composta de regras novas, que visam a dar maior espaço aos países em desenvolvimento (ainda que, muitas vezes, não sejam respeitadas), por si só, já simboliza o início da mudança.

Apesar de todas as opiniões e dados apresentados acima, a relação entre maior abertura comercial e o desenvolvimento continua a ensejar posicionamentos diversos entre 
estudiosos céticos e liberais ${ }^{39}$. Os primeiros não acreditam que existem quaisquer evidências a comprovar que uma maior liberalização do comércio proporciona maior crescimento econômico ou desenvolvimento. Por outro lado, os liberais crêem que o comércio é a forma mais eficaz de se atingir maiores níveis de desenvolvimento e de reduzir a pobreza.

Por mais controvertida que possa ser a relação entre comércio internacional e desenvolvimento econômico, o fato é que quase todos os países optaram por se vincular a um sistema que busca viabilizar o crescimento econômico por meio da liberalização do comércio. $^{40}$

Ocorre que, como foi visto, a abertura comercial, por si só, não é capaz de trazer benefícios sempre e a todos, quando o objetivo é o desenvolvimento. Pelo contrário, viu-se que, muitas vezes, a liberalização comercial pode acarretar efeitos contrários ao desenvolvimento, contribuindo para maiores desigualdades sociais e econômicas internas e entre os países.

Por este motivo, predomina hoje a idéia de que ao comércio internacional devem ser impostas regras e condições, que procurem assegurar possibilidades de desenvolvimento, especialmente aos países em desenvolvimento e de menor desenvolvimento relativo.

Nesse sentido, afirma o economista Majid ${ }^{41}$, ao tratar sobre os efeitos da globalização sobre a pobreza e as desigualdades, que há tendências positivas de que a abertura comercial pode contribuir para a redução das desigualdades e da pobreza, quando combinada a outras políticas favoráveis ao desenvolvimento, sem as quais, a liberalização não poderá alcançar objetivos maiores que os econômicos.

Hoje, a própria OMC conta com uma agenda voltada para o desenvolvimento, que determina que a busca pelo desenvolvimento deve ser o principal guia das relações comerciais entre os países ocorridas sob a sua égide.

A Carta de Havana, documento que pretendia criar a Organização Internacional do Comércio em 1948, ao fim da Segunda Guerra Mundial, já continha em seus dispositivos fortes expressões de preocupação com o desenvolvimento, acreditando-se já, naquele

\footnotetext{
${ }^{39}$ Entre os céticos, destacam-se Dani Rodrik e Joseph Stiglitz. Jagdish Bagwati, por outro lado, é considerado um renomado liberal.

${ }^{40}$ Prazeres, 2004, p. 144.

${ }^{41}$ Majid, 2003.
} 
momento, que o comércio não só era relevante para garantir o crescimento, mas também poderia contribuir para o alcance e a manutenção da paz.

Como se sabe, a Carta de Havana não nunca chegou a entrar em vigor, sendo que o que se conseguiu alcançar naquele momento foi tão somente o GATT, despido de qualquer natureza institucional e das preocupações com o desenvolvimento, concentrado apenas na redução de tarifas para promover a liberalização comercial e não o desenvolvimento ${ }^{42}$.

Conforme já mencionado anteriormente, antes da criação da $\mathrm{OMC}$ as discussões no plano internacional que surgiram relativas ao impacto do comércio para o desenvolvimento ficaram adstritas à ONU, principalmente por meio da UNCTAD.

Com os esforços dessas instituições, reconheceu-se que o comércio internacional tinha impactos econômicos suficientes para que se incluísse nas negociações multilaterais o debate sobre comércio e desenvolvimento, mesmo antes da criação da OMC.

Mesmo assim, as últimas negociações do GATT (Rodada Uruguai) e o próprio arcabouço jurídico da OMC pareciam garantir que o livre-comércio promoveria o crescimento econômico de todos aqueles que concordassem com os termos dos acordos multilaterais ${ }^{43}$.

No entanto, algum tempo depois da criação da OMC já havia uma percepção entre os países em desenvolvimento de que a liberalização do comércio deixou uma longa lista de promessas não cumpridas, que levaram esses países a reivindicar mudanças no tratamento das normas da OMC.

Assim, em 2001, o documento final aprovado no lançamento da Rodada Doha afirmava que o desenvolvimento seria a preocupação central das novas negociações. A idéia de inclusão do desenvolvimento nas negociações comerciais, porém, acaba restrita à aplicação e aprimoramento das regras de tratamento diferenciado para países em desenvolvimento, que já haviam sido inseridas no GATT, antes mesmo da criação da OMC.

O professor Welber Barral ${ }^{44}$ lembra que as principais regras diferenciadoras em favor dos países em desenvolvimento, desde o GATT, são:

a) o princípio da não-reciprocidade: como exceção genérica, esse princípio permite que vantagens concedidas por países desenvolvidos a países em desenvolvimento

\footnotetext{
${ }^{42}$ Barral, 2004, p. 126.

${ }^{43}$ Barral, 2004, p. 127.

${ }^{44}$ Barral, 2004, p. 132 e 133.
} 
não necessariamente implicarão concessões recíprocas dos países em desenvolvimento beneficiados;

b) "cláusula de habilitação": cláusula pela qual concessões comerciais a países em desenvolvimento não se estendem automaticamente aos demais membros da OMC, o que se tornou uma ressalva à cláusula da nação mais favorecida;

c) concessão de maior prazo para a implementação dos compromissos assumidos nos Acordos;

d) regras que requerem que os membros da OMC observem os interesses dos países em desenvolvimento quando aplicarem medidas que afetem seu comercio, como medidas de defesa comercial ou barreiras técnicas ao comércio.

Ocorre que "há que se atentar que a maioria das regras especiais e diferenciadas constantes no conjunto normativo da OMC tem caráter apenas retórico ou principiológico”, contendo frases vagas, sem qualquer efeito de verdadeira diferenciação no tratamento para países de menor grau de desenvolvimento econômico. Ressalta, ainda, que "mesmo considerando as regras que criam algumas obrigações materiais de diferenciação, elas estão distantes de criar uma relação mais equilibrada entre os membros da OMC".

E, por fim, lembra Barral que "mesmo os mecanismos tradicionais e de diferenciação no comércio internacional, como o princípio da não-reciprocidade, mostram sinais de esgotamento e de ineficácia como instrumentos de equalização econômica entre os membros da OMC".

Assim, duvidosa ainda a atuação da OMC com vistas ao desenvolvimento, vez que muitas de suas normas parecem pragmáticas e pouco efetivas, o que mantém as preocupações dos países em desenvolvimento constantes.

Percebe-se, portanto, que as mudanças no tratamento do desenvolvimento e de sua relação com o comércio foram principalmente devidas à maior participação dos países em desenvolvimento nas relações internacionais, que passaram a reivindicar seus interesses no cenário internacional.

Ao mesmo tempo que crescia o descontentamento dos países em desenvolvimento com os resultados econômicos do comércio internacional para o seu desenvolvimento interno, o direito internacional dos direitos humanos também se desenvolvia a passos rápidos, por meio da elaboração de diversos tratados e declarações de direitos humanos, que ressaltavam cada vez mais, a importância da cooperação e da responsabilidade internacional pela proteção e promoção desses direitos em todas as partes do mundo. 
Assim, do comércio internacional também passa a ser exigido um maior comprometimento para com os direitos humanos, principalmente porque o grau de proteção e promoção dos direitos humanos também serve como forma de mensurar o nível de desenvolvimento de uma nação e da sociedade internacional.

\subsection{COMÉRCIO E DIREITOS HUMANOS}

Além da preocupação com o impacto da liberalização comercial no desenvolvimento econômico, nos últimos anos, são levantadas também muitas questões a respeito do papel do comércio internacional no fortalecimento ou enfraquecimento dos direitos humanos e sobre a possibilidade de os acordos comerciais fazerem mais ou não fazerem nada em prol desses direitos.

Para entender melhor as exigências colocadas sobre o comércio diante das preocupações com a proteção dos direitos humanos, far-se-á, neste momento, uma breve análise histórica das lutas por esses direitos e do surgimento do Direito Internacional dos Direitos Humanos.

Bobbio $^{45}$, ao ser demandado em certa ocasião se, em meio a tantas previsíveis causas de infelicidade no mundo, ainda via algum sinal positivo, respondeu que sim, diante da “crescente importância atribuída, nos debates internacionais, entre homens de cultura e políticos, em seminários de estudo e em conferências governamentais, ao problema do reconhecimento dos direitos humanos".

Esse problema, como destaca o autor:

não nasceu hoje. Pelo menos desde o início da era moderna, através da difusão das doutrinas jusnaturalistas, primeiro, e das Declarações dos Direitos do Homem, incluídas nas Constituições dos Estados liberais, depois, o problema acompanha o nascimento, o desenvolvimento, a afirmação, numa parte cada vez mais ampla do mundo, do Estado de direito. Mas é também verdade que somente depois da Segunda Guerra Mundial é que esse problema passou da esfera nacional para a internacional, envolvendo - pela primeira vez na história - todos os povos.

A tutela dos direitos humanos surge inicialmente nos séculos XVII e XVIII com a finalidade de tentar controlar o pode do Estado. A existência de governos absolutistas que já não mais agradavam a ninguém - levou a uma reação por parte da teoria jusnaturalista, que sustentava a pré-existência de direitos de todos os homens, inatos e, portanto, válidos em qualquer tempo e lugar, independentemente da condição social ou situação geográfica. Sobre esses direitos, o rei ou imperador absoluto não poderia dispor. O 
nascimento dessa tese jusnaturalista, portanto, teve como principal objetivo combater os abusos dos Estados absolutos da época e garantir liberdades individuais a todos.

A partir dessa teoria dos direitos inatos do homem ${ }^{46}$, o tema dos direitos humanos vem se desenvolvendo, e desde a Revolução Francesa, tem passado por um processo marcante de afirmação que se iniciou com a positivação desses direitos nas Constituições liberais do final do século XVIII e começo do século XIX que, inicialmente mantinham essa idéia de buscar proteger a liberdade de ação individual da interferência estatal. Posteriormente, os direitos humanos passaram por processos de generalização, especificação e internacionalização, sobre os quais dar-se-á seguimento.

A divisão da história dos direitoa humanos em processos na sua evolução foi desenvolvida, conforme atesta Bobbio ${ }^{47}$, por Gregório Peces Barba, na "Introdução geral" à antologia de documentos Derecho positivo de los derechos humanos. Segundo Bobbio, Paces Barba apresentou a idéia de que os direitos humanos haviam passado por processos de positivação, generalização e internacionalização. Bobbio analisa esses três processos e ainda acrescenta uma quarta fase dos direitos humanos, que chamou de especificação.

A etapa da conversão dos direitos humanos em direito positivo se inicia, como já mencionado, com a inclusão dos direitos humanos nas Declarações de Direito e nas constituições dos Estados. Conforme atesta Celso Lafer ${ }^{48}$, "a etapa da positivação é indispensável, pois sem ela os direitos humanos não se completam. Seriam valores e ideais que não se realizariam plenamente". Isso porque a positivação permite a tutela jurídica dos valores da dignidade da pessoa humana.

A positivação dos direitos humanos no plano interno dos Estados se deu de modo diferente da evolução dos direitos humanos no plano internacional. Conforme foi dito, a positivação dos direitos humanos internamente se iniciou com a proteção das liberdades e garantias individuais e dos direitos civis e políticos, diante da situação em que se encontravam os súditos dos Estados soberanos, sendo que a idéia era que a lei deixasse de se voltar para o dever dos súditos e passasse a prescrever direitos dos cidadãos ${ }^{49}$.

\footnotetext{
${ }^{45}$ Bobbio, 2004, p. 66.

${ }^{46}$ Ressalte-se que a história dos direitos humanos não se inicia apenas com a teoria jusnaturalista, mas é de onde se parte no presente trabalho. Para uma análise mais acurada do processo histórico dos direitos humanos, ver Comparato, 2008.

${ }^{47}$ Bobbio, 2004, p. 67.

${ }^{48}$ Lafer, 2005, p.37.

${ }^{49}$ Bobbio, 2004, p. 22.
} 
As Declarações que permitiram a positivação dos diretos humanos, entretanto, previam em seus artigos preceitos de igualdade e liberdade para todos, indicando o caráter geral dos direitos humanos. É nessa dimensão de igualdade entre todos os homens como possuidores de direitos humanos que se encontra o processo de generalização, que por sua vez, adquire dimensão internacional com a Declaração Universal dos Direitos do Homem de $1948^{50}$ no âmbito da ONU, que determina em seu artigo $1^{\circ}$, que todos os homens nascem livres $e$ iguais em dignidade e direitos. Além desses princípios de igualdade e liberdade de direitos, também os princípios da não-discriminação e fraternidade que regem a Declaração Universal, podem ser considerados como forte expressão do processo de generalização dos direitos humanos. A característica dessa etapa no processo de afirmação dos direitos humanos, portanto, é a previsão de destinatários genéricos, representados pelos termos “o ser humano" ou "a humanidade", por exemplo.

Esses princípios do processo de generalização foram incorporados às Constituições nacionais também como embasadores dos direitos humanos no plano nacional, tal como ocorre com a Constituição brasileira de $1988^{51}$.

Por sua vez, o processo de especificação dos direitos do homem surgiu diante da impossibilidade de execução da igualdade efetiva (material) entre todos os seres humanos. Isso porque a previsão geral até então atestada na Declaração Universal e nas Constituições dos países apenas garantia uma igualdade formal entre os indivíduos, sendo que a desconsideração das diferenças entre grupos levava a uma prática de desigualdade de direitos. Por este motivo, surge a idéia de se promover direitos específicos a determinados grupos, que podemos chamar de minorias (pelo costume da utilização do termo e não pelo efetivo significado de menor representação). Trata-se, portanto, de uma fase de determinação dos destinatários e não mais de um sujeito abstrato.

Essa especificação “ocorreu com relação seja ao gênero, seja às várias fases da vida, seja à diferença entre estado normal e estados excepcionais na existência humana",52. Dessa forma, foram reconhecidas as diferenças existentes entre a mulher e o homem, as especificidades das crianças e dos idosos, dos doentes e deficientes, entre outros. Com base

\footnotetext{
${ }^{50}$ Lafer, 2005, p. 37.

${ }^{51}$ A Constituição da República Federativa do Brasil de 1988 dispõe, em seu artigo 5, que: "Todos são iguais perante a lei, sem distinção de qualquer natureza, garantindo-se aos brasileiros e aos estrangeiros residentes no País a inviolabilidade do direito à vida, à liberdade, à igualdade, à segurança e à propriedade (...)"

${ }_{52}$ Bobbio, 2004, p. 79.
} 
nessas diferenças reais e impossíveis de serem ignoradas, reconheceu-se a necessidade de conceder a essas "minorias" prerrogativas diferenciais e disposições específicas, que lhes dariam os meios para alcançar a igualdade de fato em relação aos demais, a fim de capacitá-los para o exercício das suas liberdades. Diante disso, foram aprovados documentos que atestam essa especificação, tais como a Declaração dos Direitos da Criança, de 1959, a Declaração sobre a Eliminação da Discriminação à Mulher, de 1967, entre outros.

Por fim, a etapa de internacionalização dos direitos humanos, conforme já mencionado anteriormente, toma verdadeira forma com a Declaração Universal dos Direitos do Homem $^{53}$, criada e assinada sob o consenso dos países membros da ONU. Essa etapa teve um precedente conceitual importante: $\mathrm{Kant}^{54}$, que ao analisar os níveis jurídicos no projeto de paz perpétua, lança a idéia de um direito cosmopolita, regido pelo princípio da hospitalidade universal, que permita uma interdependência dos Estados como integrantes de um Estado Universal.

Kant aponta que uma das características desse direito cosmopolita "será a de uma época da história em que a violação do direito ocorrida num ponto da terra venha a ser sentida em todos os outros" $" 55$.

Essa é a idéia que norteia a fase de internacionalização dos direitos humanos: torná-los todos direito e dever de todo indivíduo e coletividade e responsabilidade de todo Estado. Pode-se dizer, portanto, que a Declaração Universal dos Direitos do Homem é também o marco do reconhecimento do Direito Internacional dos Direitos Humanos.

A proteção dos direitos humanos no plano internacional, como já foi dito, seguiu curso diferente da positivação dos direitos humanos pelo direito interno. Foram outras as fontes que levaram o direito internacional a se preocupar com a proteção dos direitos do homem. Essas fontes possuem raízes no direito internacional humanitário, na tentativa de criação das Nações Unidas, na criação a Organização Internacional do Trabalho (OIT), mas

\footnotetext{
${ }^{53}$ É bem de ver que antes dos avanços do pós-guerra e da Declaração Universal, o caráter internacional dos direitos humanos já era evidenciado pelas normas sobre o direito da guerra e o direito internacional humanitário, pelos direitos dos trabalhadores e a criação da OIT, a proibição da escravidão, entre outros marcos que protegiam os direitos humanos, mas que não estavam ainda consolidados como direitos humanos. ${ }^{54}$ Conforme atesta o Professor Celso Lafer: "Kant, no Projeto de Paz Perpétua, discute os dois tradicionais níveis do jurídico: o jus civitatis do direito interno e o jus gentium do direito internacional público que rege as relações dos estados entre si mas a eles agrega o jus cosmopoliticium - o direito cosmopolita. Este diz respeito aos homens e aos estados em suas relações exteriores e sua interdependência como cidadãos de um Estado Universal da humanidade". (Lafer, apresentação Bobbio, 2004, p.14).
} 
principalmente nos acontecimentos da Segunda Guerra Mundial, quando tornou-se evidente a necessidade de uma verdadeira cooperação internacional para o cumprimento e execução das regras de direitos humanos. O pós Segunda Guerra, portanto, é o momento de maior crescimento do direito internacional dos direitos humanos, momento este em que a preocupação com a proteção e a garantia dos direitos do homem é atestada como um dos principais temas globais da comunidade internacional.

A etapa de internacionalização dos direitos humanos foi muito importante para corrigir a idéia de que a tutela dos direitos humanos deveria ficar adstrita à competência interna dos Estados. Essa idéia de que a proteção dos direitos humanos pertencia ao domínio reservado dos Estados concedia uma grande carga de discricionariedade aos governos, que definiam o alcance e a extensão do domínio reservado, obedecendo à lógica de seus interesses conjunturais. Não havia qualquer critério ou procedimento capaz de conferir rigor a este conceito $^{56}$.

O conseqüente entendimento de que organizações internacionais poderiam tutelar os direitos humanos, subsidiariamente, na inércia ou falha dos Estados, resultou do fato de que os direitos humanos tornaram-se objeto de interesse internacional, extrapolando a competência exclusiva dos Estados.

Assim, a proteção e garantia dos direitos humanos a todos os indivíduos deve ser vista, hoje, como o principal objetivo a ser alcançado e promovido pela comunidade internacional, tratando-se de um interesse coletivo, ou seja, de todos os povos e nações, vez que não escolhe, nem discrimina as diferenças.

Podemos concluir, portanto, que a doutrina dos direitos humanos, como bem nos lembra Bobbio $^{57}$, desde seu primeiro aparecimento no pensamento político dos séculos XVII e XVIII:

já evoluiu muito, ainda que entre contradições, refutações, limitações. Embora a meta final de uma sociedade de livres e iguais, que reproduza na realidade o hipotético estado de natureza, precisamente por ser utópica, não tenha sido alcançada, foram percorridas várias etapas, das quais não se poderá facilmente voltar atrás.

\footnotetext{
${ }^{55}$ Lafer, apresentação Bobbio, 2004, p. 14.

${ }^{56}$ Amaral Jr., 2002, p. 644.

${ }^{57}$ Bobbio, 2004, p. 78.
} 
Portanto, tanto no plano internacional como nos âmbitos nacionais, a proteção aos direitos humanos tem sido apresentada como uma das principais preocupações, sendo que diversas políticas públicas são desenvolvidas, tendo por justificativa a promoção e a garantia dos direitos humanos.

Com o tempo, tornou-se ainda mais claro que qualquer medida nacional ou internacional que se venha a tomar deve sempre contribuir para a efetividade dos direitos humanos, não bastando que apenas deixem de lhes causar prejuízos.

Apesar dessas evidências, ainda como parte do entendimento do processo evolutivo dos direitos humanos, convém traçar breves comentários sobre o a sua concepção contemporânea.

O processo recente de internacionalização dos direitos humanos, que, conforme dito, surge no pós-guerra, como resposta às atrocidades e aos horrores cometidos pelo regime nazista, é que dá origem à chamada concepção contemporânea dos direitos humanos, que foi introduzida com a Declaração Universal dos Direitos do Homem de 1948 e reiterada pela Convenção de Viena sobre direitos humanos, de $1993^{58}$.

O pós-guerra passa a significar a reconstrução dos direitos humanos, que veio para consertar e prevenir uma nova ruptura com estes direitos, como ocorrera durante a Segunda Guerra Mundial.

Assim, a concepção contemporânea dos direitos humanos, introduzida pela Declaração Universal dos Direitos Humanos, é caracterizada pela universalidade e pela indivisibilidade desses direitos. Como bem ressalta Flávia Piovesan ${ }^{59}$ :

Universalidade, porque clama pela extensão universal dos direitos humanos, sob a crença de que a condição de pessoa é o requisito único para a titularidade de direitos, considerando o ser humano como um ser essencialmente moral, dotado de unicidade existencial e dignidade. Indivisibilidade, porque a garantia dos direitos civis e políticos é condição para a observância dos direitos sociais, econômicos e culturais - e vice-versa. Quando um deles é violado, os demais também o são. Os direitos humanos compõem, assim, uma unidade indivisível, interdependente e inter-relacionada, capaz de conjugar o catálogo de direitos civis e políticos ao catálogo de direitos sociais, econômicos e culturais. Consagra-se, desse modo, a visão integral dos direitos humanos.

\footnotetext{
${ }^{58}$ Piovesan, 2004, p.21.
}

${ }^{59}$ Piovesan, 2004, p. 22. 
O direito internacional, portanto, é fundamental para o estabelecimento dessa concepção contemporânea dos direitos humanos como direitos universais e indivisíveis, sendo indissociáveis uns dos outros.

Isso porque essa concepção reforça a idéia de que é necessário que haja uma cooperação internacional no sentido de promover e proteger esses direitos a todos os indivíduos, sem distinção quanto ao local em que se encontram. Assim, um Estado europeu é tão responsável pelos direitos humanos de um indivíduo africano quanto o próprio Estado africano ao qual pertence esse indivíduo ${ }^{60}$.

Dessa forma, evidente que a concepção contemporânea dos direitos humanos carrega a idéia de que esses direitos são de todos os indivíduos, como "nacionais" do mundo, daquele Estado Universal de Kant, sendo, portanto, obrigação de todos promovê-los e defendê-los.

O direito internacional dos direitos humanos pressupõe como legítima e necessária a preocupação de atores estatais e não-estatais a respeito do modo pelo qual os habitantes de outros Estados são tratados. A rede de proteção dos direitos humanos internacionais busca redefinir o que é matéria de exclusiva jurisdição doméstica dos Estados. ${ }^{61}$

Isso significa dizer que "a proteção dos direitos humanos não deve se limitar ao domínio reservado do Estado, isto é, não deve se restringir à competência nacional exclusiva ou à jurisdição doméstica exclusiva, porque revela tema de legítimo interesse internacional"62.

Essa idéia de responsabilização dos Estados pelos direitos humanos de todos os indivíduos já aponta para a necessidade de se observar os impactos das relações internacionais sobre esses direitos. Assim, se as decisões tomadas em âmbito interno e internacional sobre as relações comerciais entre os países podem trazer conseqüências positivas ou negativas aos direitos humanos, essas decisões devem ser cuidadosamente estudadas para que estejam de acordo com a responsabilidade internacional dos Estados por estes direitos.

\footnotetext{
60 Importante ressaltar que a questão da responsabilidade internacional pelos direitos humanos não necessariamente legitima a interferência de um Estado em outro pela defesa dos direitos humanos. Esse debate, bastante rico e extenso, não é objeto do presente trabalho, cabendo apenas essa pequena ressalva. Ademais, cumpre esclarecer ainda que existe também um debate acadêmico sobre a universalidade e o relativismo cultural dos direitos humanos, que também não será discutido no presente trabalho, mas que deve ser levado em conta quando se tratar de ingerências de um Estado em outro.

${ }^{61}$ Sikkink, 1993.

${ }^{62}$ Piovesan, 2004, p. 23.
} 
Ainda, antes de adentrar na análise da relação entre o comércio internacional e os direitos humanos, cumpre esclarecer que os direitos humanos foram didaticamente divididos em gerações, que indicam o momento histórico em que surgiram como principal preocupação.

Essa categorização das gerações dos direitos humanos pela positivação progressiva nos ordenamentos jurídicos nacionais, demonstra, como Bobbio ${ }^{63}$ conclui, que os direitos humanos não nascem todos de uma vez, mas acompanham uma evolução histórica da humanidade e surgem conforme as necessidades do homem se modificam. Direitos humanos não são, portanto, direitos inatos, mas sim históricos.

Assim, conforme já dito anteriormente, os primeiros direitos humanos a serem incorporados aos ordenamentos jurídicos nacionais exaltavam as liberdades e garantias individuais, a fim de impedir a atuação do Estado absoluto sobre a liberdade dos indivíduos, reflexo direto das reivindicações da Revolução Francesa. Esses são os chamados direitos humanos de primeira geração, cuja maior preocupação é proteger a liberdade dos indivíduos.

Posteriormente, com o enriquecimento da burguesia e a formação de uma classe operária explorada pelas gigantes indústrias, nascidas da Revolução Industrial, percebeu-se a necessidade de se inserir o indivíduo como participante do bem-estar social. Dessa forma, passou-se da fase de não intervenção do Estado nas liberdades individuais à necessidade de atuação do Estado para garantir a inclusão social do indivíduo. A segunda geração de direitos humanos, portanto, é composta pelos direitos sociais e econômicos, cujo objetivo é alcançar a igualdade entre os indivíduos.

Por fim, incorporaram-se os direitos de terceira geração, que ainda é considerada uma categoria heterogênea e vaga ${ }^{64}$, mas na qual podem-se incluir, sem dúvidas: o direito a um meio ambiente não poluído, o direito ao desenvolvimento e o direito à paz. Tratam-se, principalmente de direitos de titularidade coletiva, dos povos, cujo valor exaltado é a solidariedade $^{65}$.

\footnotetext{
${ }^{63}$ Bobbio, 2004, p. 26.

${ }^{64}$ Bobbio, 2004, p. 25.

65 Ao tratar do direito ao desenvolvimento, no próximo capítulo, serão apresentadas maiores considerações sobre esta geração de direitos humanos.
} 
Convém mencionar que já se fala em direitos novos que, segundo Bobbio ${ }^{66}$, só se encaixariam em uma quarta geração de direitos, referentes aos direitos ligados à biogenética, surgidos diante das amplas possibilidades de manipulação tecnológica da genética e biologia.

Toda essa divisão didática criada para o entendimento dos direitos humanos fundamenta a idéia de que os direitos humanos têm um caráter predominantemente histórico, ou seja, eles nascem quando devem e podem nascer. Não nascem todos de uma vez e nem de uma vez por todas ${ }^{67}$.

Importante destacar que essa divisão não pode ser utilizada para se dizer que uma geração de direitos é mais importante que a outra, pois, de acordo com a concepção contemporânea dos direitos humanos, predominante atualmente, todos os direitos, de todas as gerações, são igualmente importantes e indispensáveis, não havendo que se falar em hierarquia entre os direitos humanos, que são, ressalte-se novamente, universais e indissociáveis uns dos outros.

Assim, as gerações de direitos se intercomunicam e são dependentes umas das outras, sendo certo, por exemplo, que os direitos de segunda geração surgem a fim de permitir que as liberdades da primeira geração sejam efetivamente garantidas a todos os indivíduos.

Conforme visto no sub-capítulo anterior, fica bastante claro que o comércio internacional possui impactos determinantes no desenvolvimento dos países e, conseqüentemente, na capacidade de todos os seus nacionais terem acesso especialmente aos direitos de segunda geração.

Muitos procuraram, equivocadamente, indicar que essas gerações deve, indicar uma ordem hierárquica entre os direitos humanos, baseando-se no fato de que a legislação e a doutrina sobre direitos humanos esteve classicamente vinculada mais aos direitos políticos, em especial durante o século XIX. Ocorre que, após a Declaração Universal dos Direitos do Homem, ampliou-se o espectro dos direitos fundamentais no plano internacional, passando a equiparar os direitos econômicos, sociais e culturais, nos quais encontram-se o direito à educação, à saúde, à cultura, ao trabalho e a salários justos, entre outros, aos direitos civis e políticos já consolidados.

\footnotetext{
${ }^{66}$ Bobbio, 2004, pp. 25-26.

${ }^{67}$ Bobbio, 2004, p.25.
} 
Essa nova amplitude dos direitos humanos é resultado do entendimento de que a realização dos direitos econômicos, sociais e culturais é indispensável para a dignidade do homem e para o livre desenvolvimento de sua personalidade ${ }^{68}$.

EA Declaração Universal foi posteriormente complementada pelo Pacto Internacional sobre Direitos Econômicos, Sociais e Culturais e pelo Pacto Internacional sobre Direitos Civis e Políticos, ambos de 1966, que, conjuntamente com o primeiro documento formam a chama Carta Internacional de Direitos (Bill of Rights).

Cumpre ressaltar ainda que a Declaração Universal dos Direitos do Homem e os dispositivos dos Pactos Internacionais foram reforçados pela Declaração da Conferência de Viena das Nações Unidas sobre os Direitos Humanos, de 12 de julho de 1993. Essa declaração reafirma a ligação íntima entre todos os direitos humanos, sua interdependência, sua indissociabilidade e seu caráter universal. Ademais, esse documento afirma ainda a interdependência da democracia, do desenvolvimento e dos direitos do homem.

Esses documentos visualizam os problemas específicos da relação entre comércio internacional, desenvolvimento e direitos humanos e se dão conta da complexidade jurídica que envolve a regulamentação dos direitos humanos no âmbito internacional, diante do sistema de produção e de comércio mundial. O desenvolvimento deixa de ser visto como um mero fim econômico ou apenas como um meio para alcançar democracias estáveis, passando a englobar um catálogo de direitos humanos.

Se de um lado, tem-se que o fortalecimento e a segurança dos direitos humanos dependem em grande medida do desenvolvimento econômico. Por outro lado, o desenvolvimento econômico e o processo de globalização causam impactos no âmbito do exercício e proteção dos direitos humanos, vez que criam situações que condizem ou propiciam sua violação pelos Estados, organizações internacionais, empresas transnacionais e outros sujeitos de caráter privado ${ }^{69}$.

Neste momento, já tratamos de um conceito de desenvolvimento mais amplo, que engloba diversos outros aspectos além do desenvolvimento econômico, nos termos da evolução proposta anteriormente. Dessa forma, entende-se que não há que se falar em processo de

${ }_{69}^{68}$ Mastaglia, 2007, p. 122.

${ }^{69}$ Mastaglia, 2007, p. 103. 
desenvolvimento, se este estiver dissociado da preocupação com o respeito e garantia dos direitos humanos, tendo como fim último a pessoa humana, sujeito central de todos os direitos humanos.

A importância do desenvolvimento já era visualizada nestes termos em outros documentos, como a Carta da Organização dos Estados Americanos (OEA), que em seu artigo 33, prevê que: “o desenvolvimento é responsabilidade primordial de cada país e deve constituir um processo integral e contínuo para a criação de uma ordem econômica e social justa que permita e contribua para a plena realização da pessoa humana”. E em seu artigo 30, o documento esclarece que o desenvolvimento integral engloba os campos econômico, social, educacional, cultural, científico e tecnológico.

Ao conceito de um desenvolvimento como processo integral soma-se o conceito de desenvolvimento como direito humano, primeira mostra de que o sistema econômico e o acesso à riqueza que este gera no ideário ocidental se encontram ligados ao sistema de direitos humanos e, em conseqüência, não podem ser considerados como extremos contrapostos.

Dessa forma, deve-se buscar maneiras para fazer com que o comércio contribua de fato para o desenvolvimento e para os direitos humanos. O Professor Rubens Ricupero ${ }^{70}$ acredita nas vantagens da liberalização comercial, mas ressalta quatro aspectos que, a seu ver, são fundamentais para o processo de desenvolvimento e devem sempre pautar as negociações comerciais. São eles:

1. Um Estado eficaz e competente, dotado de quadros capazes de formular e executar um projeto nacional de desenvolvimento;

2. Um projeto de longo prazo, isto é, de caráter estratégico, que não se resume à correta política macroeconômica, mas abrange componente social e estratégia de competitividade tecnológica e exportadora;

3. Preocupação constante e efetiva com o combate á pobreza, o esforço de diminuir a desigualdade e promover melhor distribuição da riqueza e da renda;

4. Prioridade central à educação e à formação de recursos humanos, à promoção da cultura, ciência e tecnologia, como chave para ser bem-sucedido num desenvolvimento que se torna, cada vez mais, intensivo conhecimento.

\footnotetext{
${ }^{70}$ Ricupero, 2001, p. 85 e 86.
} 
Certo é, portanto, que o comércio é incapaz de promover, sozinho, o desenvolvimento e os direitos humanos. Ele é capaz de estimular o crescimento econômico, mas não possui a mesma competência para distribuir riqueza e renda ${ }^{71}$.

Ao mesmo tempo, percebeu-se a importância do desenvolvimento econômico e social dos países no desenvolvimento individual de cada ser humano, sendo que a possibilidade de se desenvolver é imprescindível para a execução e garantia de outros direitos humanos, como direito à saúde, ao trabalho, entre outros. Torna-se fundamental, portanto, a noção de um direito ao desenvolvimento como direito garantidor de uma série de outros direitos fundamentais para o homem.

Dessa forma, a comunidade internacional não mais poderia ignorar as falhas nos modelos econômicos predominantes e deveria exigir mudanças que buscassem de fato o bem estar de todo ser humano por meio da promoção do desenvolvimento de todas os povos e indivíduos.

Ainda que se entenda que a desigualdade é um problema interno de cada Estado e que a este cabe resolvê-lo por meio de políticas públicas nacionais, é fato que o comprometimento dos países com uma maior abertura comercial limita seu poder de elaboração de políticas públicas voltadas ao combate à desigualdade e a outros problemas sociais internos (como as violações de direitos humanos).

Assim, a comunidade internacional não pode se esquivar e não se responsabilizar pelas mazelas sociais e políticas dos Estados, ao exigir destes maiores compromissos pela liberalização do comércio internacional.

Dessa forma, países ricos, países em desenvolvimento e países de menor desenvolvimento relativos, bem como as organizações internacionais são todos responsáveis solidários pela promoção de um comércio justo, cujo objetivo maior é enfrentar os problemas sociais que assolam todas as partes do mundo.

Esta premissa será melhor desenvolvida a seguir e norteará os próximos capítulos deste trabalho. A seguir, discorrer-se-á sobre o nascimento da idéia de um direito ao desenvolvimento e a importância da evolução do conceito de desenvolvimento para esta conquista.

\footnotetext{
${ }^{71}$ Di Sena Jr., 2004, p. 67.
} 


\section{II - O DIREITO AO DESENVOLVIMENTO}

Como apresentado no capítulo anterior, o direito ao desenvolvimento é considerado um direito humano da chamada terceira geração, que são direitos que se consideram necessários para garantir o exercício dos demais (de primeira e segunda geração) ou uma derivação necessária destes ${ }^{72}$.

Esses direitos de terceira geração são aqueles de titularidade também da comunidade e são conhecidos como direitos de solidariedade (em combinação com os direitos de liberdade de primeira geração - com os direitos de igualdade - de segunda geração) ${ }^{73}$.

Como bem destaca o professor André de Carvalho Ramos ${ }^{74}$, os direitos de terceira geração "são frutos da descoberta do homem vinculado ao planeta Terra, com recursos finitos, divisão absolutamente desigual de riquezas em verdadeiros círculos vicioso de miséria e ameaças cada vez mais concretas à sobrevivência da espécie humana”.

Isso quer dizer que esses direitos são aqueles que visam a proteger e garantir o reconhecimento da dignidade humana a todos os indivíduos e povos das gerações presentes e futuras.

Assim, o direito ao desenvolvimento, entendido como um direito de solidariedade, quer acima de tudo, ressaltar a importância da cooperação internacional para a garantia de direitos mínimos essenciais para a manutenção da dignidade humana, imprescindível para a sobrevivência da espécie.

$\mathrm{Na}$ verdade, como se verá ao final das análises contidas neste capítulo, o direito ao desenvolvimento corresponde a um resultado da busca por alternativas aos impactos negativos do neoliberalismo e da globalização, e, como destaca Celso Lafer ${ }^{75}$, "reivindicado pelos países sub-desenvolvidos nas negociações no âmbito do diálogo Norte/Sul, sobre uma nova ordem econômica internacional".

\footnotetext{
${ }^{72}$ Mastaglia, 2007, p. 123.

${ }^{73}$ Outros exemplos de direitos de terceira geração são o direito à autodeterminação dos povos, o direito à paz e o direito a um meio ambiente equilibrado.

${ }^{74}$ Ramos, 2005, p. 85.

${ }^{75}$ Lafer, 1988, p. 131.
} 
Assim, o direito ao desenvolvimento não deixa de ser uma resposta às reivindicações por um sistema econômico mais justo e por regras de comércio internacional mais preocupadas com os impactos negativos da liberalização comercial para os direitos humanos.

Fato é que hoje, o direito ao desenvolvimento é veementemente afirmado com um direito humano que visa garantir aos povos e indivíduos o acesso a diversos outros direitos fundamentais que não podem ser deixados de lado na conceituação do desenvolvimento.

No entanto, a caracterização do direito ao desenvolvimento de forma sólida como um direito humano não ocorreu de forma rápida e incontroversa, sendo resultado de diversos fatores que colaboraram para a sua consolidação, especialmente com a evolução do conceito de desenvolvimento, discussão essa já iniciada no capítulo anterior.

Foi visto que as relações econômicas entre os Estados passaram a assumir um outro papel, que não se refere apenas ao desenvolvimento econômico de cada Estado participante das relações internacionais, mas ao desenvolvimento pessoal de cada indivíduo e dos povos como coletividade, dependente de efetiva proteção de diversos direitos humanos tanto dentro de cada país, como também internacionalmente.

A crescente e cada vez mais atuante preocupação com o problema do desenvolvimento e da influência deste na efetivação de outros direitos fundamentais culminou com o nascimento da teoria da existência do direito ao desenvolvimento. Mais do que isso, nasce a idéia do direito ao desenvolvimento como um direito humano, que deverá, portanto, ser protegido por todos os Estados e indivíduos como fundamental para a dignidade humana. Nesse sentido, a noção de desenvolvimento também não se restringe mais às questões econômicas, mas passa a refletir também outras conotações (social e política, etc) que se inter-relacionam no âmbito global.

Diante dessa nova acepção, o direito ao desenvolvimento passa a ser defendido como uma prerrogativa do ser humano, assim como dos povos, em sua coletividade, de igualdade de oportunidades para se desenvolver. A partir de então, diversos documentos internacionais passaram a elencar o direito ao desenvolvimento como um dos direitos humanos e determinando obrigações e orientações para o cumprimento desse direito nos âmbitos nacional e internacional.

Neste capítulo, dar-se-á continuidade à análise da evolução do conceito de desenvolvimento, iniciada no capítulo anterior, para culminar com o estabelecimento de 
um direito humano ao desenvolvimento, cujo conteúdo também será apresentado neste momento. Para finalizar este capítulo, será feita a inter-relação entre o direito ao desenvolvimento e o direito à educação, que, por sua vez, será objeto de estudo do próximo capítulo.

\subsection{A EVOLUÇÃO DO CONCEITO DE DESENVOLVIMENTO}

Para tratar do tema do direito ao desenvolvimento é importante pensar na evolução do próprio conceito de desenvolvimento, que, conforme já mencionado anteriormente, antes era entendido como puramente econômico e hoje, como bem lembra Cláudia PerroneMoisés $^{76}$, ganha outras conotações, pressupondo uma aproximação integrada (econômica e social) e uma ação global.

Assim, conforme já mencionado anteriormente, a noção de desenvolvimento surge direta e unicamente atrelada à noção de crescimento econômico, visto como o principal objetivo de um Estado em suas relações econômicas internacionais. Posteriormente, novas teorias surgem para agregar ao conceito de desenvolvimento outros valores além do fator econômico, considerados fundamentais para que se possa afirmar a real ocorrência do desenvolvimento.

Como bem ressalta Carolina Pancotto Bohrer Munhoz ${ }^{77}$, a questão do desenvolvimento tem origens tanto teóricas quanto empíricas, estas últimas representadas pelas recorrentes crises econômicas do sistema capitalista. Quanto às teorias, Adam Smith foi o primeiro teórico a tocar diretamente no assunto do desenvolvimento, seguido por diversos autores que passaram a questionar quais eram as causas do desenvolvimento, ou seja, do que uma nação precisava para prosperar.

Principalmente após a Segunda Guerra Mundial, com o processo de descolonização dos países africanos e a afirmação do princípio da autodeterminação dos povos, seguido do despertar dos então chamados países de terceiro mundo, passou-se a se questionar não mais quais as causas do desenvolvimento, mas sim o que levava um país ao subdesenvolvimento.

As discussões sobre o desenvolvimento e o subdesenvolvimento tomam maior força e melhor forma após a década de 1990, com o fim da Guerra Fria e a acentuação dos efeitos

\footnotetext{
${ }^{76}$ Perrone-Moisés, 1998, p. 49.

77 2004, p. 2.
} 
da globalização da economia. Esse período foi marcado por um altíssimo crescimento econômico mundial, principalmente em alguns países em desenvolvimento, possibilitado pela globalização, levando o mundo a acreditar que a nova liberalização teria acabado com os períodos de recessão econômica.

No entanto, ao contrário, o final da década de 1990 foi marcado por outras crises econômicas, que assolaram os países em desenvolvimento, como o Brasil, o México e os Tigres Asiáticos. Essas crises colocaram em xeque a premissa de que a globalização era altamente benéfica aos países, passando-se a discutir seus malefícios também.

Ao mesmo tempo em que cresciam os debates e as opiniões divergentes sobre as vantagens e desvantagens da globalização, constatou-se que, apesar do alto grau de crescimento econômico de alguns países, a vida da maioria da população mundial não apresentava melhorias, pois não se verificava aumentos relevantes na maioria dos indicativos de vida, como acesso à educação e à saúde básicas, índice de mortalidade infantil, entre outros.

Assim, o debate sobre a conceituação do desenvolvimento emergiu rapidamente, trazendo diversas posições sobre o seu conteúdo, impossibilitando uma definição do termo que fosse universalmente aceita.

Pode-se dizer que existem basicamente duas correntes neste debate. A primeira, com ênfase na acumulação de capital, corresponde àquela que entende que desenvolvimento é sinônimo de crescimento econômico, que, por sua vez, é capaz de melhorar os padrões de vida e o desenvolvimento da sociedade, por si só.

A segunda corrente, por outro lado, considera que o crescimento econômico é sim indispensável para o desenvolvimento, porém é insuficiente. Para os defensores dessa vertente, o desenvolvimento implica também mudanças qualitativas não só no modo de vida, mas também nas instituições que compõem a sociedade e em suas estruturas $\operatorname{produtivas}^{78}$.

Conforme já mencionado acima, a preocupação com a questão do desenvolvimento é bastante antiga, podendo ser identificada uma discussão preliminar sobre o tema nos ensinamentos de Adam Smith, em sua obra A riqueza das nações, de 1776.

\footnotetext{
${ }^{78}$ Munhoz, 2004, p. 3.
} 
A tese fundamental de Smith era de que o homem trabalhador não é capaz de produzir tudo aquilo de que precisa para sua sobrevivência. Dessa forma, ele deve se ater a produzir aqueles bens para os quais possui habilidade ou recursos e adquirir de outros aqueles bens que não pode produzir. Assim, o sistema de trocas, com base na especialização do trabalho, seria a premissa inicial do pensamento de $\mathrm{Smith}^{79}$. Para este autor, o elemento essencial do aumento da riqueza nacional é o trabalho produtivo, entendido como aquele trabalho que produz um excedente de valor sobre o seu custo de produção ${ }^{80}$.

Dessa forma, os mercados deveriam ser livres para que as nações pudessem oferecer e adquirir os bens necessários sem obstáculos. E essa liberalização seria capaz de aumentar os lucros e gerar mais empregos, contribuindo para o crescimento econômico da nação. $\mathrm{O}$ desenvolvimento, para Smith, seria impulsionado pelo lucro transformado em novos investimentos, que, por sua vez, possibilita a criação de mais empregos, que aumenta a dimensão do mercado, retornando ao produtor como lucro novamente, reiniciando o processo cumulativo de crescimento.

A teoria clássica de Smith foi ainda aperfeiçoada pelo seu principal discípulo David Ricardo, em 1817, que, em sua obra Princípios de economia política e tributação, buscou tratar não apenas da investigação sobre a formação da riqueza, mas também sobre a forma de sua distribuição entre capitalistas, trabalhadores e proprietários de terra ${ }^{81}$, acreditando que a concentração de renda deveria ocorrer em favor dos capitalistas, pois seriam eles os responsáveis pelo acúmulo de capital, gerador do aumento do nível de emprego, promovendo assim o crescimento econômico ${ }^{82}$.

A verdade é que tanto Smith quanto Ricardo, além de outros teóricos clássicos, como John Stuart Mill, buscavam descobrir as causas do desenvolvimento das nações ricas.

Em contraposição a esta escola, surge o pensamento de Karl Marx, que afirma que, ao contrário de que pregavam os clássicos, a verdadeira causa do crescimento econômico dos capitalistas era o desemprego crescente dos trabalhadores, explorados pelos capitalistas, e a concentração de renda e de riqueza. Afirmava Marx que a lógica capitalista dos clássicos acabava tornando-se contraditória e auto-destrutiva, pois levaria a crises periódicas cada

\footnotetext{
${ }^{79}$ Smith, 1996.

${ }^{80}$ Munhoz, 2004, p.4.

${ }^{81}$ Ricardo, 1978.

${ }^{82}$ Munhoz, 2004, p. 5.
} 
vez mais agudas, geradas pelo empobrecimento da população trabalhadora e pela conseqüente diminuição do ritmo de crescimento do consumo global.

O pensamento de Marx contribuiu, posteriormente, para o surgimento de uma nova escola da teoria econômica, conhecida como neo-clássica, que tenta reafirmar os princípios da escola clássica.

Essa bifurcação no pensamento econômico levou ao surgimento de uma corrente híbrida de pensadores, que passaram a mesclar as teorias apresentadas pela teoria neo-clássica e a marxista. Os principais exemplos dessa corrente híbrida são Joseph Schumpeter ${ }^{83}$ e John Maynard Keynes.

Importante ressaltar que já neste momento, Schumpeter, apesar de basear-se em algumas premissas da escola clássica, diferencia claramente os conceitos de desenvolvimento e crescimento econômico, entendendo que o primeiro consistia nas mudanças da vida econômica que não eram impostas de fora, mas que surgiam de dentro, pela própria iniciativa da nação. O crescimento, por sua vez, não suscita qualquer fenômeno qualitativamente novo ${ }^{84}$.

Keynes vai ainda mais além: suas idéia surgem no momento em que busca-se uma solução para o problema do desenvolvimento, diante das crises econômicas experimentadas pelos países ocidentais a partir de meados do século XIX. O desenvolvimento de alguns países, mais industrializados, passou a contrastar com a falta ou a ausência de desenvolvimento em outros países, levando diversos autores a se preocuparem com a noção de desenvolvimento ligada à questão da distribuição de renda ${ }^{85}$.

A depressão da década de 1930 foi determinante para que Keynes, em sua obra A teoria geral do emprego, do juro e da moeda, de 1936, criticasse os primados da teoria clássica, passando a defender uma atuação mais efetiva do Estado no direcionamento da economia, de forma a suavizar as flutuações econômicas e a complementar a iniciativa privada em relação à realização do investimento.

Após a Segunda Guerra Mundial, há uma mudança da perspectiva do pensamento, com a prolação de uma Nova Ordem Econômica Internacional (NOEI), baseada nos laços de

\footnotetext{
${ }^{83}$ Em 1910, Schumpeter publicou a obra Teoria do desenvolvimento econômico, na qual entende a inovação empresarial como a principal força do processo de crescimento econômico.

${ }^{84}$ Schumpeter, 1982, p.47.

${ }^{85}$ Munhoz, 2004, p. 8.
} 
cooperação entre as Nações, além das conseqüências advindas da descolonização, que introduz um expressivo número de países de Terceiro Mundo ou subdesenvolvidos na Assembléia Geral da ONU.

Conforme mencionado anteriormente, com o despertar dos países subdesenvolvidos, principalmente nas décadas 1960 e 1970, passou-se a reivindicar, no âmbito internacional, uma maior ajuda dos países desenvolvidos ${ }^{86}$. Com isso, as diversas correntes da teoria econômica passaram a centrar suas preocupações não mais nas causas do desenvolvimento, mas sim nas origens e nos termos do subdesenvolvimento.

Neste contexto, cumpre ressaltar a contribuição significativa da América Latina, por meio dos estudos da Comissão Econômica para América Latina e Caribe (CEPAL), que buscavam determinar quais os obstáculos para o desenvolvimento existentes em cada país latino-americano.

Essa nova corrente do pensamento econômico parte da análise das desigualdades entre países desenvolvidos e em desenvolvimento e da vinculação entre esses grupos de países, a partir da lógica da teoria clássica das vantagens comparativas, na qual os países em desenvolvimento não precisariam se industrializar para se desenvolver, devendo ater-se à produção de produtos primários e à importação de produtos industrializados.

O pensamento cepalino, porém, verifica que esse sistema é falho e que a tendência é de que os preços dos produtos primários diminuam enquanto crescem os dos bens industrializados, gerando sempre um déficit aos países em desenvolvimento. Assim, pregava-se a industrialização do Terceiro Mundo como principal meio de se alcançar o desenvolvimento. Seguidamente, os países da América Latina iniciaram intensos processos de industrialização interna.

No entanto, logo percebeu-se que somente o processo de industrialização não estava sendo suficiente para a melhoria nas condições de vida da população latino-americana, tornandose necessária a realização de outras mudanças estruturais de grande abrangência para a região, como por exemplo, a reforma agrária e fiscal, além de programas de políticas sociais.

Este é um momento significativo para a evolução do conceito de desenvolvimento, vez que as orientações da CEPAL contribuíram em muito para a incorporação da análise 
sociológica do desenvolvimento, o que enfatizou a diferenciação entre crescimento econômico e desenvolvimento, sendo que o crescimento foi diretamente vinculado ao desempenho econômico, enquanto o desenvolvimento estava relacionado à distribuição social dos frutos do crescimento econômico ${ }^{87}$.

As constatações e os estudos da CEPAL foram de grande importância para a incorporação da preocupação pelas condições de vida do homem no tema do desenvolvimento, de forma a reformular a sua conceituação, afastando-o da concepção que o considerava sinônimo de crescimento econômico ${ }^{88}$.

Atualmente, portanto, conforme já mencionado no capítulo anterior, prevalecem as correntes que entendem que o desenvolvimento é algo a mais que o crescimento econômico, ainda que deste não possa prescindir.

Assim, ainda na linha dos pensadores econômicos, cumpre ressaltar os ensinamentos de dois grandes estudiosos sobre o conceito de desenvolvimento hoje, quais sejam: Douglas C. North e Amartya Sen.

North é um dos fundadores do chamado novo institucionalismo nos estudos de economia, que busca deixar de lado a análise histórica econômica para debruçar-se sobre estudos mais voltados à evolução de arranjos institucionais. Essa mudança se dá a partir do seu trabalho Sources of Productivity Change in Ocean Shipping, 1600-1850, de 1968, no qual constata que em um determinado período, as evoluções institucionais foram mais importantes que as inovações tecnológicas para o aumento da produtividade da indústria de transporte marítimo.

Assim, North busca entender o papel das instituições na evolução das sociedades, cuja pesquisa culmina na publicação da obra Institutions, Institutional Change and Economic Performance, de 1990, que lhe rendeu o Prêmio Nobel de Economia, em 1993. Neste trabalho, North procura demonstrar como o crescimento de longo prazo, ou a evolução

\footnotetext{
${ }^{86}$ Munhoz, 2004, p. 9.

${ }^{87}$ Munhoz, 2004, p. 10.

${ }^{88}$ Ressalte-se que os trabalhos da CEPAL, cujas teorias foram desenvolvidas por Raúl Prebisch, foram importante impacto não apenas na América Latina, mas no mundo todo, contribuindo para diversas mudanças no pensamento econômico e nas relações internacionais, além de ser determinante para que a voz dos países em desenvolvimento tenha tomado força para reivindicar seus interesses no plano multilateral. Os estudos de Prebisch e da CEPAL foram fundamentais para a criação da UNCTAD, cujo primeiro Secretário Geral foi justamente Raúl Prebisch, em reconhecimento aos seus trabalhos realizados no âmbito da CEPAL.
} 
histórica, de uma sociedade é condicionado pela formação e evolução de suas instituições ${ }^{89}$.

$\mathrm{O}$ autor parte do pressuposto de que as instituições reduzem a incerteza pelo fato de que proporcionam uma estrutura à vida diária, definindo e limitando o conjunto de escolhas dos indivíduos, podendo ser formais, como as leis, ou informais, como aquelas decorrentes dos usos e costumes.

Assim, North acredita que a eficiência das suas instituições é que garantem que determinada sociedade seja também eficiente, ou seja, possa desenvolver-se. Dessa forma, acredita que o subdesenvolvimento dos países de terceiro mundo pode ser explicado em grande parte pela ineficiência de suas instituições ${ }^{90}$. Assim, é a incapacidade das sociedades para estabelecer o cumprimento de contratos de forma eficaz e a baixo custo que constitui o principal motivo da estagnação histórica e do subdesenvolvimento contemporâneo do terceiro mundo ${ }^{91}$.

Carolina P. B. Munhoz ${ }^{92}$, ao analisar o pensamento de North, ressalta que ele:

(...) desenvolve um modelo institucional para procurar demonstrar que as instituições determinam o desempenho das economias, mas não consegue responder de forma definitiva o que cria instituições eficientes. De acordo com o autor, a existência de instituições relativamente produtivas em algumas partes do mundo e informação barata sobre as características resultantes do desenvolvimento dessas instituições constitui um incentivo poderoso para mudar economias de fraco desenvolvimento. Mas essa constatação não impede North de questionar se é possível generalizar as forças que contribuem para tais mudanças e o que deve ser feito para inverter as características crescentes de resultados de uma determinada matriz institucional.

E completa lembrando que essas questões são válidas na medida em que a experiência demonstra que não há uma fórmula única capaz de responder aos problemas dos diversos países em desenvolvimento, sendo que o próprio North coloca que ambientes institucionais diferentes dão respostas diversas ao mesmo estímulo, daí a impossibilidade de generalização.

De qualquer forma, a grande contribuição de North para o conceito de desenvolvimento que se busca adotar no presente trabalho é que ele contribuiu para a humanização do tema, uma vez que admite expressamente que o homem, seja pelas instituições por ele criadas,

\footnotetext{
${ }^{89}$ Munhoz, 2004, p. 11.

${ }^{90}$ North, 2001, p. 155.

${ }^{91}$ North, 2001, p. 76.

92 Munhoz, 2004, p. 14.
} 
seja por seu próprio papel como agente econômico tomador de decisões, influencia de forma direta o processo de desenvolvimento econômico.

O principal autor na nova conceituação de desenvolvimento, cujo pensamento deve nortear este trabalho, é Amatya Sen, Prêmio Nobel de Economia em 1998, que em sua obra Desenvolvimento como liberdade, defende a idéia de que o desenvolvimento não se reduz ao mero crescimento econômico, abrangendo outros valores ${ }^{93}$.

Para Sen, o desenvolvimento é encarado como a eliminação de privações de liberdade que limitam as escolhas e as oportunidades das pessoas de exercerem de forma ponderada sua condição de indivíduo ${ }^{94}$. Por este motivo, defende que as principais origens da privação de liberdade sejam extintas, tais como a pobreza, a tirania, a falta de oportunidades econômicas, a intolerância, entre outros ${ }^{95}$.

O autor estuda os meios para a vida do ser humano, não se restringindo a condições econômicas para qualificar a situação de vida de um indivíduo, sendo que uma boa condição de vida deverá abordar diversos aspectos além do nível de renda, permitindo uma análise bem mais abrangente do desenvolvimento, que passa a englobar questões como acesso à saúde e à educação, inexistência do temor de fomes coletivas, possibilidade de participação efetiva na vida da comunidade ou exercício de direitos civis e políticos, entre outros $^{96}$.

Nesse sentido, a questão do desenvolvimento pressupõe uma análise integrada das atividades econômicas, sociais e políticas. O desenvolvimento, nessa visão, é um processo de transformação de uma sociedade no qual o ser humano desempenha um papel fundamental, e por meio dele são geradas mudanças que vão além da produção econômica, alcançando também as demais relações sociais existentes nessa mesma sociedade. Dessa forma, a nova concepção e análise do desenvolvimento passa a levar em consideração a influência do ser humano e da própria ação humana no desenvolvimento e não mais apenas aspectos econômicos ${ }^{97}$.

Isso porque, para Sen, como bem atesta Carolina P. B. Munhoz ${ }^{98}$ :

\footnotetext{
${ }^{93}$ Munhoz, 2004, p. 11.

${ }^{94}$ Sen, 2000, p. 10.

${ }^{95}$ Sen, 2000, p. 18.

${ }^{96}$ Munhoz, 2004, p. 15.

${ }^{97}$ Munhoz, 2004, p. 15.

${ }^{98}$ Munhoz, 2004, p. 15.
} 
(...) a liberdade individual não apenas faz parte do desenvolvimento, mas também o promove, ou seja, exerce um papel tanto constitutivo como instrumental no desenvolvimento. $\mathrm{O}$ que as pessoas conseguem realizar de fato é influenciado por liberdades políticas, oportunidades econômicas, poderes sociais e também condições que habilitam as pessoas a alcançar seus objetivos, como educação básica e boa saúde. Mas ao mesmo tempo as instituições que proporcionam essas oportunidades são influenciadas pelo exercício das liberdades das pessoas, como, por exemplo, a liberdade de participação nas escolhas sociais e na tomada de decisões públicas que incentivam o progresso dessas oportunidades.

Percebe-se, portanto, que a evolução do conceito de desenvolvimento culmina em posicionamentos que buscam aproximá-lo ao ser humano e à ação humana, que é capaz de influenciar os níveis de desenvolvimento de determinadas nações.

Assim, o reconhecimento do desenvolvimento fica atrelado a uma série de constatações sobre a qualidade de vida dos indivíduos, sem as quais não seria possível se afirmar a presença do desenvolvimento. Essas constatações, por sua vez, aproximam-se em muito dos princípios norteadores dos direitos humanos, com base principalmente na preservação e na garantia da dignidade humana.

Isso significa que os níveis de acesso à educação e à saúde, de participação do cidadão no Estado, de preservação do meio ambiente, de igualdade de distribuição de renda, além de outros fatores determinantes para a definição da qualidade de vida de um ser humano, devem influenciar significativamente a constatação do grau de desenvolvimento de um país.

Como resultado dessa mudança de entendimento sobre o conceito de desenvolvimento, é curioso ressaltar que, até 1990, a matéria referente ao desenvolvimento era objeto exclusivo do Relatório sobre Desenvolvimento Mundial do Banco Mundial, sendo o critério utilizado o do PIB "per capita", que é um critério exclusivamente econômico. Em 1990 foi criado no âmbito da ONU o Índice de Desenvolvimento Humano (IDH), que combina três indicadores: expectativa de vida, grau de escolaridade e alfabetização e nível de renda per capita.

A criação do $\mathrm{IDH}^{99}$, no âmbito do Programa das Nações Unidas para o Desenvolvimento (PNUD), teve a intenção justamente de substituir a utilização do PIB como principal indicador do desenvolvimento de uma nação. Criado por Mahbub ul Haq com a

\footnotetext{
${ }^{99}$ O IDH é a base dos Relatórios de Desenvolvimento Humano, elaborados anualmente pelo PNUD, que levam em conta o conceito de desenvolvimento humano como parte do pressuposto de que para aferir o avanço de uma população não se deve considerar apenas a dimensão econômica, mas também outras características sociais, culturais e políticas que influenciam a qualidade da vida humana.
} 
colaboração de Amartya Sen, "o IDH pretende ser uma medida geral, sintética, do desenvolvimento humano. Não abrange todos os aspectos de desenvolvimento e não é uma representação da 'felicidade' das pessoas, nem indica 'o melhor lugar no mundo para se viver" ${ }^{\prime 100}$, mas aos poucos, tornou-se referência mundial, como melhor indicador para se medir o desenvolvimento nos países, substituindo o PIB nesta tarefa, o qual permanece utilizado, porém, não mais visto como o indicador do desenvolvimento, ou seja, o IDH contribuiu para a inserção de outros fatores, além do econômico, no conceito de desenvolvimento.

Neste sentido são as palavras de Sen, no prefácio ao Relatório de Desenvolvimento Humano de $1998^{101}$ :

Devo reconhecer que não via no início muito mérito no IDH em si, embora tivesse tido o privilégio de ajudar a idealizá-lo. A princípio, demonstrei bastante ceticismo ao criador doRelatório de Desenvolvimento Humano, Mahbub ul Haq, sobre a tentativa de focalizar, em um índice bruto deste tipo - apenas um número -, a realidade complexa do desenvolvimento e da privação humanos. (...) Mas, após a primeira hesitação, Mahbub convenceu-se de que a hegemonia do PIB (índice demasiadamente utilizado e valorizado que ele queria suplantar) não seria quebrada por nenhum conjunto de tabelas. As pessoas olhariam para elas com respeito, disse ele, mas quando chegasse a hora de utilizar uma medida sucinta de desenvolvimento, recorreriam ao pouco atraente PIB, pois apesar de bruto era conveniente. (...) Devo admitir que Mahbub entendeu isso muito bem. E estou muito contente por não termos conseguido desviá-lo de sua busca por uma medida crua. Mediante a utilização habilidosa do poder de atração do IDH, Mahbub conseguiu que os leitores se interessassem pela grande categoria de tabelas sistemáticas e pelas análises críticas detalhadas que fazem parte do Relatório de Desenvolvimento Humano.

De todo o exposto acima, nota-se que a concepção contemporânea de desenvolvimento busca indicar neste termo expressões explícitas de diversos direitos humanos, como o direito à educação e à saúde. Essa aproximação, considerada cada vez mais intrínseca à constatação do desenvolvimento foi fundamental para a concepção de um direito ao desenvolvimento.

Uma vez que o atendimento a direitos humanos básicos caracteriza a presença do desenvolvimento e uma vez que os direitos humanos devem obrigatoriamente ser realizados e protegidos, nada mais lógico que se encarar o desenvolvimento como um

100 PNUD, Desenvolvimento Humano e IDH (página da Internet), disponível em: $<$ http://www.pnud.org.br/idh/>. Acesso em: 05 jan. 2009.

${ }^{101}$ PNUD, 1998, p. 23. Disponível em: <http://hdr.undp.org/en/media/hdr_1999_front.pdf >. Acesso em: 05 jan. 2009. 
direito. E, mais do que um direito qualquer, o desenvolvimento adquire natureza jurídica de direito humano, dada a sua importância para a garantia de diversos outros direitos.

No próximo item, passa-se a analisar o desenvolvimento a partir de uma perspectiva jurídica, como um direito humano. Para tanto, cumpre apresentar o momento em que o desenvolvimento passa a ser visto como direito e de que forma a evolução do conceito de desenvolvimento influenciou os debates sobre o direito ao desenvolvimento no plano internacional.

\subsection{HISTÓRICO DO DIREITO AO DESENVOLVIMENTO}

Conforme mencionado anteriormente, a nova concepção de desenvolvimento contribuiu de forma expressiva para a classificação do direito ao desenvolvimento como um direito humano, pois, conforme exposto, aproximou o tema do desenvolvimento da condição humana e da ação do indivíduo, qualificando-as como medidoras do desenvolvimento, permitindo que o desenvolvimento deixasse de ser encarado como um direito passivo dos Estados de se desenvolver sem interferência para ser visto como um direito que implica uma atividade do ser humano ${ }^{102}$.

Apesar de o conceito de desenvolvimento já apontar, no início do século XX, para uma maior aproximação com os princípios de direitos humanos, o termo "direito ao desenvolvimento" demora um pouco mais a surgir.

É possível dizer que o direito ao desenvolvimento já estava implicitamente previsto, devendo deveria ser universalmente protegido e garantido, na própria Declaração Universal dos Direitos do Homem de 1948, nos artigos que tratam dos direitos econômicos, sociais e culturais ${ }^{103}$.

Similarmente, alguns conceitos, como o princípio da auto-determinação dos povos, previstos no Pacto Internacional sobre Direitos Econômicos, Sociais e Culturais, também já demonstram uma aproximação dos direitos humanos com o desenvolvimento.

\footnotetext{
102 Perrone-Moisés, 1998, p. 50.

${ }^{103}$ Cherem, 2004, p. 96. O artigo 22 da Declaração Universal prevê que: "Todo homem, como membro de sociedade, tem direito à segurança social e à realização, pelo esforço nacional, pela cooperação internacional e de acordo com a organização e recursos de cada Estado, dos direitos econômicos, sociais e culturais indispensáveis à sua dignidade e ao livre desenvolvimento de sua personalidade." O artigo 28 deste documento, por sua vez, atesta que: "Todo homem tem direito a uma ordem social e internacional em que os direitos e liberdades estabelecidas na presente Declaração possam ser plenamente realizados”.
} 
No entanto, a expressão somente é utilizada pela primeira vez pelo oficial senegalês Keba M'Baye, na conferência inaugural do Instituto de Direitos Humanos de Estrasburgo, em $1971^{104}$. Nesta ocasião, M'Baye argumentou que o desenvolvimento era um direito de todos os seres humanos e que cada indivíduo teria o direito à vida, mas também o direito de longevidade.

No mesmo período, Karel Vasak, diretor do já mencionado instituto, apresentou sua teria sobre a terceira geração de direitos humanos que, conforme exposto anteriormente, seguiram os direitos civis e políticos (primeira geração) e econômicos, sociais e culturais (segunda geração $)^{105}$. Esse "novo" grupo de direitos humanos seriam direitos coletivos, também chamados de direitos de solidariedade e englobava o direito ao desenvolvimento, o direito a um meio ambiente saudável e ecologicamente balanceado, o direito à paz e o direito à propriedade do patrimônio comum da humanidade ${ }^{106}$.

A partir de então, a Assembléia Geral da ONU, bem como a Comissão de Direitos Humanos passam a enfatizar o direito ao desenvolvimento como um direito humano, atestando-se a necessidade de uma cooperação internacional de países desenvolvidos e em desenvolvimento para a implementação desse direito, uma vez que, na qualidade de direito humano, é do interesse de todos que ele seja implementado para todas as nações e indivíduos.

Foi a Comissão de Direitos Humanos da ONU que mencionou pela primeira vez de forma oficial a existência de um direito ao desenvolvimento, quando adotou a Resolução 4 (XXXIII) de 1977, requisitando que o ECOSOC convidasse o Secretário Geral da ONU, em colaboração com a UNESCO e demais agências especializadas das Nações Unidas, para elaborar um estudo sobre as dimensões internacionais do direito ao desenvolvimento.

No início de 1979, esse estudo foi publicado na forma de um relatório analítico sobre as fontes e o conteúdo do direito ao desenvolvimento ${ }^{107}$, que serviu de base para que a Comissão de Direitos Humanos reiterasse, na sua Resolução 5 (XXXV), de 2 de março de 1979, que o direito ao desenvolvimento era um direito humano e que a igualdade de

\footnotetext{
${ }^{104}$ M' Baye, 1972, p. 502.

${ }^{105}$ Malhotra, 2005, p. 130.

106 Alston, 1987, p. 813.

${ }^{107}$ O relatório, de janeiro de 1979, foi intitulado de "The international dimensions of the right to development as a human right in relation with other human rights based on international cooperation, including the right to peace, taking into account the requirements of the New International Economic Order and the fundamental human needs, report of the Secretary-General" (Doc. ONU: E/CN.4/1334).
} 
oportunidades era uma prerrogativa tanto das nações como dos indivíduos que constituem as nações ${ }^{108}$. Ao final daquele ano, a Assembléia Geral da ONU reconhecia o direito ao desenvolvimento como direito humano pela primeira vez ${ }^{109}$.

Em atenção às recomendações do mencionado relatório quanto à necessidade de se dar continuidade aos estudos sobre o tema para que fosse possível determinar o conteúdo preciso do direito ao desenvolvimento, a Comissão de Direitos Humanos instituiu o primeiro grupo de trabalho governamental de peritos ${ }^{110}$, cuja tarefa era a de estudar os objetivos e o conteúdo do direito ao desenvolvimento, bem como os meios mais efetivos de se garantir a realização dos direitos econômicos, sociais e culturais em todos os países, com particular atenção aos obstáculos encontrados pelos países em desenvolvimento para garantir e proteger os direitos humanos.

Este primeiro grupo de trabalho foi também responsável pela elaboração de um projeto da Declaração sobre o Direito ao Desenvolvimento ${ }^{111}$, que foi submetida a diversas deliberações para, em 1986, ser adotada pela Assembléia Geral da ONU, por 146 votos contra 1 voto contrário (EUA) e 8 abstenções $^{112}$, concedendo de modo inquestionável, assim, o status de direito humano ao direito ao desenvolvimento.

\subsubsection{A Declaração sobre o direito ao desenvolvimento}

São vários os aspectos da Declaração sobre o direito ao desenvolvimento que contribuíram para que esse direito fosse aceito como direito humano por toda a comunidade internacional e para o Direito Internacional dos Direitos Humanos.

Por exemplo, em seu artigo $1^{\circ}$, o documento proclama que:

\section{Artigo 1}

1. O direito ao desenvolvimento é um direito humano inalienável em virtude do qual toda pessoa humana e todos os povos estão habilitados a participar do desenvolvimento econômico, social, cultural e político, a ele contribuir e dele desfrutar, no qual todos os direitos humanos e liberdades fundamentais possam ser plenamente realizados.

\footnotetext{
${ }^{108}$ Oliveira, 2005, p. 513 e 514.

${ }^{109}$ Resolução 34/46, de 23 de novembro de 1979.

${ }^{110}$ Este primeiro grupo de trabalho foi constituído nos termos da Resolução 36 (XXXVII) da Comissão de Direitos Humanos, em 11 de março de 1981, aprovada pela decisão do ECOSOC 1981/149, de 08 de março de 1981.

111 A Declaração sobre o Direito ao Desenvolvimento foi adotada pela Resolução 41/128, da Assembléia Geral da ONU, em 4 de dezembro de 1986.

112 Os oito países que se abstiveram de votar sobre a adoção da Declaração sobre o direito ao desenvolvimento foram: Dinamarca, República Federal da Alemanha, Reino Unido, Finlândia, Islândia, Suécia, Japão e Israel.
} 
2. O direito humano ao desenvolvimento também implica a plena realização do direito dos povos de autodeterminação que inclui, sujeito às disposições relevantes de ambos os Pactos Internacionais sobre Direitos Humanos, o exercício de seu direito inalienável de soberania plena sobre todas as suas riquezas e recursos naturais.

Este conceito amplo de desenvolvimento como avanços econômicos, sociais, culturais e políticos, direcionados à completa realização de todos os direitos humanos e liberdades fundamentais, transforma o direito ao desenvolvimento de uma mera reivindicação por uma ordem econômica internacional colaboradora, nascida no período de descolonização, em um direito humano multifacetado.

Nesse sentido, ressalte-se um relatório do Secretário Geral da ONU para a Comissão de Direitos Humanos sobre a realização dos direitos econômicos, sociais e culturais, ao comentar a noção de desenvolvimento presente na Declaração sobre direito ao desenvolvimento, no qual consta que:

A Declaração sobre o Direito ao Desenvolvimento envolve o desenvolvimento em termos amplos e completo, como um processo global e multidimensional que engloba as esferas econômica, social, cultural e política que são interdependentes e complementares. A Declaração destaca uma série de princípios importantes sobre os quais o desenvolvimento deve se basear, incluindo o princípio da igualdade, não-discriminação, solidariedade, confiança e da justiça social. Esses princípios não podem ser desrespeitados mesmo que no curto prazo. O progresso que se busca alcançar não é apenas relacionado ao crescimento econômico, à eficiência financeira e a melhorias nos indicadores macroeconômicos, mas é aquele que pode ser mensurado em termos de justiça social, igualdade, qualidade de vida e respeito pela dignidade fundamental de todos os indivíduos, grupos e povos ${ }^{113}$.

Assim, Rajeev Malhotra entende que a primeira contribuição da Declaração sobre o Direito ao Desenvolvimento foi inserir em um instrumento jurídico um novo conceito de desenvolvimento, garantido como direito humano ${ }^{114}$.

Além disso, a definição desse direito na Declaração formalizou definitivamente a noção da indivisibilidade dos direitos humanos, declarando que a realização do direito ao

113 ONU. E/CN.4/Sub.2/1996/12. "The realization of economic, social and cultural rights", 2 jul. 1996. Tradução livre de "the Declaration on the Right to Development approaches development in broad and comprehensive terms, as a multidimentional and global process encompassing the economic, social, cultural, civil and political spheres which are interdependent and complementary. It underlines a number of important principles on which development must be based including equality, non-discrimination, solidarity, selfreliance and social justice. Respect for these principles cannot be waived even in the short-term. The progress sought is not just economic, and financial efficiency and as improvement in the macroeconomic indicators but one can be measured in terms of social justice, equality, well-being and respect for the fundamental dignity of all individuals, groups and peoples".

${ }^{114}$ Malhotra, 2005, p. 132. 
desenvolvimento envolve simultaneamente a realização dos direitos políticos e civis, e dos direitos econômicos, sociais e culturais.

Outra importante característica desta declaração é que ela não enfatiza apenas os resultados do processo de desenvolvimento, que poderiam ser identificados como a realização total de outros direitos humanos, mas ressalta também a importância do próprio processo de realização desses direitos, definindo o direito ao desenvolvimento como um direito de participar, contribuir e gozar dos frutos do desenvolvimento multifacetado.

Por fim, Malhotra ressalta a importante contribuição da Declaração para o Direito Internacional dos Direitos Humanos por trazer como característica do direito ao desenvolvimento dois aspectos: um individual e outro coletivo. Assim, ao identificar o ser humano e os povos como beneficiários desse direito, agregam-se elementos tanto dos direitos individuais como dos direitos coletivos. E, ainda, ao colocar os Estados como o principal detentor do dever de realizar o direito ao desenvolvimento, a Declaração enfatiza a importância da cooperação internacional ${ }^{115}$.

Os professores Antonio Carlos Wolkmer e Maria de Fátima S. Wolkmer ressaltam que a importância da Declaração sobre Direito ao Desenvolvimento em aspectos centrais nos quais se baseia a Declaração: i) a relevância da participação; ii) o fato de ser concebida no contexto das necessidades básicas de Justiça Social; iii) o fato de enfatizar tanto a necessidade de adoção de programas e políticas nacionais como a de cooperação internacional. Além disso, proclama que a pessoa humana é o sujeito central de desenvolvimento e deve ser participante beneficiária deste direito ${ }^{116}$.

Apesar de suas valiosas contribuições ao dar os principais contornos do direito ao desenvolvimento, a Declaração sobre o Direito ao Desenvolvimento está ainda repleta de ambigüidades, resultantes dos esforços de se acomodarem os diferentes posicionamentos dos países desenvolvidos e em desenvolvimento, mantendo, portanto, a necessidade de maior esclarecimento sobre o conteúdo e o quadro operacional para a realização do direito ao desenvolvimento.

\subsubsection{A construção do direito ao desenvolvimento como direito humano: os próximos grupos de trabalho e a Declaração de Viena}

\footnotetext{
${ }^{115}$ Malhotra, 2005, p. 133.

${ }^{116}$ Wolkmer e Wolkmer, 2005, p. 71.
} 
De 1986 a 1989, em três sessões anuais, o grupo de trabalho sobre o direito ao desenvolvimento não conseguiu elaborar recomendações concretas para esclarecer o conteúdo desse direito e suas implicações. Assim, em março de 1989, a Comissão de Direitos Humanos ${ }^{117}$ solicitou ao Secretário-Geral da ONU que organizasse uma consulta global sobre a realização do direito ao desenvolvimento, envolvendo especialistas na área, representantes das instituições do sistema das Nações Unidas, de organizações regionais inter-governamentais e ONGs interessadas. O propósito da consulta seria focar-se nos principais problemas enfrentados na implementação da Declaração, no critério utilizado para identificar o progresso e o mecanismo para estimular esse progresso.

A Consulta Global sobre a Realização do Direito ao Desenvolvimento ocorreu entre os dias 08 e 12 de janeiro de 1990, em Genebra e trouxe alguns resultados positivos para a o debate sobre o tema. Além de reconhecer que o direito ao desenvolvimento como direito humano estava relacionado com outras áreas da atividade humana de uma forma complexa e interdependente e que essas inter-relações estavam aos poucos sendo compreendidas, as consultas chegaram a algumas conclusões sobre o conteúdo do direito ao desenvolvimento, os obstáculos enfrentados para sua implementação e os critérios para medição do progresso $^{118}$.

Em síntese, as consultas permitiram reafirmar a importância da justiça social e da realização dos direitos humanos nas estratégias nacionais e internacionais de desenvolvimento, impossibilitando, portanto, o enfoque único no crescimento econômico.

Em 1993, a Comissão de Direitos Humanos decidiu estabelecer um novo grupo de trabalho sobre o direito ao desenvolvimento pelo período de $3 \operatorname{anos}^{119}$, com o objetivo de identificar os principais obstáculos à implementação da Declaração sobre o Direito ao Desenvolvimento com base nas informações fornecidas pelos Estados Membros e outras fontes a fim de recomendar caminhos e formas para a realização deste direito por todos os países.

Neste mesmo ano, em junho, foi realizada a Conferência Mundial de Direitos Humanos da ONU, em Viena. Tanto em seus debates preparatórios como em seu documento final, o direito ao desenvolvimento ocupou um lugar de destaque.

\footnotetext{
${ }^{117}$ Resolução 1989/45, de 06 de março de 1989.

118 Para maiores detalhes sobre os resultados da Consulta Global sobre a Realização do Direito ao Desenvolvimento, ver Malhotra, 2005, pp. 133-136.

${ }^{119}$ Resolução 1993/22 da Comissão de Direitos Humanos.
} 
Como já afirmado anteriormente, o sistema de direitos humanos não engloba tão somente os direitos políticos e civis, mas também os direitos econômicos, sociais e culturais e seu cumprimento está intimamente ligado ao desenvolvimento e à democracia. A ONU tem reafirmado essa relação até o ponto de que esta forma em que estão relacionados também foi um dos temas centrais da Conferência Mundial de Direitos Humanos.

A Declaração e Programa de Ação de Viena ${ }^{120}$, além de consagrar a interdependência entre democracia, desenvolvimento e respeito aos direitos humanos e às liberdades fundamentais ${ }^{121}$, estabeleceu no início do seu parágrafo 10 que:

A Conferência Mundial de Direitos Humanos reafirma o direito ao desenvolvimento, conforme estabelecido na Declaração sobre o Direito ao Desenvolvimento, como um direito universal e inalienável e parte dos direitos humanos fundamentais.

Como afirma a Declaração sobre o Direito ao Desenvolvimento, a pessoa humana é o sujeito central do desenvolvimento.

Assim, tanto na Declaração sobre o Direito ao desenvolvimento, como na Declaração de Viena, afirmou-se que o direito ao desenvolvimento é um direito universal e inalienável que integra os direitos humanos fundamentais, sendo que a pessoa humana é o sujeito central deste direito.

Importante ressaltar que a Declaração de Viena também estabeleceu que os Estados devem cooperar mutuamente para alcançar o desenvolvimento e eliminar os obstáculos ao desenvolvimento, assim como a comunidade internacional deve propiciar uma cooperação internacional eficaz para a realização do direito ao desenvolvimento e para a eliminação dos obstáculos para o seu alcance, por meio de políticas eficientes de desenvolvimento no plano nacional, assim como por meio de relações econômicas igualitárias e um cenário econômico favorável no plano internacional.

Cumpre esclarecer, ainda, que a Declaração de Viena teve um papel de grande significância para o direito ao desenvolvimento, considerada hoje como um marco para o seu reconhecimento como direito humano. Isso porque esta declaração foi adotada por consenso, sendo a primeira vez que o direito ao desenvolvimento foi aceito como direito

${ }^{120}$ ONU. A/CONF.157/23, de 12 de julho de 1993.
${ }^{121}$ Oliveira, 2005, p. 516. 
humano, nos termos da Declaração de 1986, por todos os Estados Membros da ONU, sem ressalvas $^{122}$.

É bem verdade que, como observa o professor Celso Lafer ${ }^{123}$, "o consenso de Viena é ainda um consenso frágil. É, diria, uma 'invariante axiológica' que requer uma dedicada obra de adensamento". No entanto, como bem lembra Silvia Menicucci de Oliveira ${ }^{124}$, o consenso de Viena "permite inferir que o direito ao desenvolvimento passou a ter maior apoio político em decorrência da conquista do alcance de um consenso internacional".

Apesar do sucesso considerável da Conferência de Viena, o segundo grupo de trabalho sobre o direito ao desenvolvimento não conseguiu aproveitar-se do consenso presente por aquela ocasião para discutir os temas propostos no momento de sua constituição. Ao contrário, os debates foram marcados pela divergência de opiniões, com modestas contribuições para o esclarecimento e implementação do direito ao desenvolvimento ${ }^{125}$.

Ao final do mandato do segundo grupo de trabalho, em 1996, a Comissão de Direitos Humanos logo decidiu instituir um novo grupo inter-governamental de peritos ${ }^{126}$, cujo o objetivo seria elaborar uma estratégia para a implementação e promoção do direito ao desenvolvimento nos termos da Declaração de 1986.

Como resultado dos trabalhos deste terceiro grupo, apresentou-se uma estratégia global pela promoção e implementação do direito ao desenvolvimento com recomendações específicas para o escritório do Alto Comissário para Direitos Humanos e para os Estados parte. As recomendações incentivam a integração de uma série de indicadores de direitos humanos na área dos direitos civis, culturais, econômicos, políticos e sociais, resultantes do trabalho entre as agências do sistema das Nações Unidas.

Além disso, foram feitas sugestões para lidar com o problema da dívida externa dos países em desenvolvimento, sobre cooperação técnica, questões relacionadas ao comércio, investimentos e recursos aos países em desenvolvimento, afirmando a necessidade de

\footnotetext{
${ }^{122}$ Lembre-se que a Declaração sobre o Direito ao Desenvolvimento obteve 1 voto contra dos EUA e 8 abstenções. Ainda, em 1992, a Declaração do Rio, fruto da Conferência das Nações Unidas sobre Meio Ambiente e Desenvolvimento, também proclamou o direito ao desenvolvimento, vinculado à proteção do meio ambiente, implicando que aquele direito deve ser um direito sustentável. No entanto, observe-se que os EUA, apesar de aceitarem a Declaração do Rio, deixaram claro que mantinham sua posição de objeção ao direito ao desenvolvimento, o qual entendiam como uma meta e não como um direito.

${ }^{123}$ Lafer, 1997, p. 6.

${ }^{124}$ Oliveira, 2005, p. 517.

${ }^{125}$ Malhotra, 2005, p. 137.

${ }^{126}$ Resolução 1996/15 da Comissão de Direitos Humanos, de 11 de abril de 1996.
} 
diálogo entre as instituições internacionais de desenvolvimento, finanças e comércio. Também ressaltou a importância das mudanças na legislação interna dos países para tornar possível que as disposições nos tratados internacionais tenham aplicação direta no ordenamento jurídico interno dos países.

Por fim, ressaltou as prováveis contribuições da criação de um mecanismo de acompanhamento (follow-up) sobre a implementação do direito ao desenvolvimento. Em resposta a essas recomendações, em $1998^{127}$, foi criado o quatro grupo de trabalho, cujo enfoque seria esse mecanismo de acompanhamento do progresso na realização do direito ao desenvolvimento.

Este grupo deveria ser assistido por um perito independente, Arjun Sengupta, designado pelo presidente da Comissão de Direitos Humanos, com base no critério de elevada competência no campo do direito ao desenvolvimento.

O grupo de trabalho tem a função de monitorar e revisar o progresso alcançado na promoção e implementação do direito ao desenvolvimento nas esferas nacional e internacional, apresentar recomendações e análises profundas para a completa realização deste direito. O trabalho do perito independente, por sua vez, era apresentar estudos anuais sobre determinados aspectos, a fim de direcionar o grupo a uma discussão centrada em assuntos específicos.

Até o momento, o Sengupta já apresentou oito relatórios e o grupo de trabalho já se reuniu em cinco sessões ${ }^{128}$. Percebe-se que, já é passado o período de afirmação do direito ao desenvolvimento como direito humano, questão essa já consolidada e afirmada constantemente pela comunidade internacional. Os trabalhos da Comissão de Direitos Humanos, no momento, têm se centrado na busca de mecanismos de implementação desse direito em todos os Estados, a fim de garanti-lo a todos os seres humanos.

Não é o objetivo do presente estudo, porém, aprofundar-se nas propostas e atividades que têm sido realizadas para alcançar a realização total do direito ao desenvolvimento, cabendo apenas apresentar a evolução do reconhecimento deste direito no cenário internacional.

\subsection{O CONTEÚDO DO DIREITO AO DESENVOLVIMENTO}

\footnotetext{
${ }^{127}$ Resolução 1998/62 da Comissão de Direitos Humanos, de 22 de abril de 1998.

${ }^{128}$ Os documentos resultantes dos estudos do perito independente e do atual grupo de trabalho sobre direito ao desenvolvimento encontram-se disponíveis em: < http://www.unhchr.ch/development/right-03.html >. Acesso em: 02 jan. 2009.
} 
Como já mencionado, restou evidente que o desenvolvimento, aqui considerado, não é sinônimo de crescimento econômico, apresentando um conteúdo múltiplo e complexo que implica progresso social, econômico, cultural e político como fins justificáveis e a interação harmônica desses elementos ${ }^{129}$.

Pode-se dizer, portanto, que o conceito de desenvolvimento é relativo e dinâmico, não existindo um modelo único de desenvolvimento, pois esse depende de situações particulares e dos diferentes desafios de cada época ${ }^{130}$.

Não obstante, o conteúdo do direito ao desenvolvimento possui alguns parâmetros que não podem ser ignorados, centrados nas noções de equidade e justiça. Dessa forma, apesar de possuir um conteúdo amplo e variável, os contornos principais do direito ao desenvolvimento foram determinados pela Declaração de 1986, que identifica a presença de todos os demais direitos humanos.

Assim, a Declaração sobre o Direito ao Desenvolvimento define este direito de forma ampla, englobando diversos aspectos econômicos, sociais, culturais, políticos e civis, vinculado à realização de todos os direitos humanos e liberdades fundamentais, estando o indivíduo na posição de sujeito central desse direito.

Nesse sentido, Agostinho dos Reis Monteiro ${ }^{131}$ bem define o direito ao desenvolvimento:

O direito ao desenvolvimento tem uma natureza mista, complexa, plural e dialética. É um direito dos indivíduos e dos povos (que os Estados representam), mas é, antes de mais, um “direito do homem”. É um direito a um desenvolvimento global, responsável e solidário com toda a humanidade, no espaço e no tempo, fundado no respeito da dignidade dos seres humanos e na sua participação, para melhorar a sua qualidade de vida, sobretudo dos mais pobres e vulneráveis, por meio da produção sustentável e justa distribuição dos "bens públicos globais" necessários a uma vida digna, saudável, longa e criadora.

Segundo o autor, todos os direitos humanos, depois do direito à vida, se resumem num meta-direito ao desenvolvimento como direito a uma vida com o maior nível de dignidade humana possível. É, portanto, direito a um processo de desenvolvimento que respeite e favoreça a realização de todos os direitos.

\footnotetext{
${ }^{129}$ Oliveira, 2005, p. 547.

${ }^{130}$ Espiell, 1981, pp. 200-203.

${ }^{131}$ Monteiro, 2003, p. 776.
} 
A partir da concepção de Amartya $\operatorname{Sen}^{132}$ de que a liberdade não só é o objetivo primeiro do desenvolvimento, como também é seu principal meio, Mohammed Bedjaoui ${ }^{133}$ entende o direito ao desenvolvimento como o alfa e o ômega dos direitos humanos, o primeiro e o último direito humano, o princípio e o fim, o meio e o objetivo dos direitos humanos, numa palavra, é o direito nuclear do qual derivam todos os outros.

Assim, conclui-se, como bem lembra a professora Cláudia Perrone Moisés ${ }^{134}$, que o direito ao desenvolvimento é considerado um direito - individual, mas cujo exercício é coletivo que possibilita a realização de todos os demais direitos humanos já consagrados. Em outras palavras "o direito ao desenvolvimento pode ser considerado não como um direito à parte, mas como o direito que proporcionará os meios necessários para que se realizem os demais" $" 135$.

O direito ao desenvolvimento, portanto, não deixa de ser uma síntese de todos os direitos humanos, que tem como objetivo tornar concreto o artigo 28, da Declaração Universal dos Direitos do Homem, segundo o qual todo homem tem direito a uma ordem social e internacional em que todos os direitos e liberdades possam ser plenamente realizados.

Esse tratamento do direito ao desenvolvimento como um direito síntese dos direitos civis, políticos, econômicos, sociais e culturais existentes concede dinamismo ao conceito de direitos humanos por meio de um consenso crescente sobre os objetivos de desenvolvimento.

Assim, o direito ao desenvolvimento faria parte do conjunto de direitos humanos e seus objetivos principais seriam o de promover e proteger esse conjunto, tanto em âmbito nacional como internacional, a fim de fortalecer e aprofundar a indivisibilidade e interdependência de todos os direitos humanos.

Muitos países desenvolvidos se utilizaram dessa teoria do direito ao desenvolvimento como direito síntese para refutar a sua existência, alegando que os direitos humanos abarcados pelo direito ao desenvolvimento já se encontravam protegidos de forma suficiente pelos instrumentos internacionais de promoção e proteção dos direitos humanos.

\footnotetext{
132 Sen, 2000, p. 18.

${ }^{133}$ Apud Steiner e Alston, 2000, p. 1321.

${ }^{134}$ Perrone Moisés, 2005, p. 247.

${ }^{135}$ Perrone Moisés, 1999, p. 192.
} 
No entanto, esses posicionamentos não levam em consideração a contribuição do direito ao desenvolvimento como direito humano quanto à constatação de que o desenvolvimento não pode prescindir da realização de todos os demais direitos humanos. Assim, o direito ao desenvolvimento ressalta a importância de se garantir a efetividade de todos os direitos humanos conjuntamente e não apenas os destaca individualmente. Por este motivo, o direito ao desenvolvimento teria grande importância e utilidade jurídica, por contribuir para a afirmação de que não existe hierarquia entre os direitos humanos e que cada um desses direitos deve ser implementado conjuntamente e sem prejudicar a realizabilidade dos demais.

Por outro lado, parte da doutrina, com especial contribuição dos ensinamentos do perito independente para o direito ao desenvolvimento, Arjun Sengupta, entende este direito como um novo direito humano que emergiu na comunidade internacional como uma resposta consensual a novos problemas e percepções, que ultrapassa a idéia de um conglomerado de direitos humanos ${ }^{136}$. Essa corrente, a fim de combater as críticas apresentadas à teoria do direito síntese, passa a entender o direito ao desenvolvimento como um direito a um processo de desenvolvimento.

Assim, com base nos elementos essenciais do conceito de direito ao desenvolvimento determinado pelo parágrafo $1^{\circ}$, do artigo $1^{\circ}$, da Declaração de 1986, Silvia Menicucci de Oliveira $^{137}$ afere que:

(i) há um direito humano chamado direito ao desenvolvimento que é inalienável; (ii) há um processo particular de desenvolvimento econômico, social, cultural e político, no qual todos os direitos humanos e liberdades fundamentais possam ser realizados; e (iii) o direito ao desenvolvimento é um direito humano em virtude do qual toda pessoa humana e todos os povos estão intitulados a participar no, contribuir para e gozar daquele processo particular de desenvolvimento.

Com isso, conclui que o direito ao desenvolvimento é um direito a um processo de desenvolvimento no qual todos os direitos humanos e liberdades possam ser plenamente realizados e deve ser exercido de maneira que assegure:

(i) que os indivíduos envolvidos participem efetiva e plenamente em todos os estágios do processo de decisão; (ii) que os indivíduos tenham igual oportunidade de acesso aos recursos; (iii) que eles sejam intitulados a uma justa distribuição dos benefícios do desenvolvimento e de renda; (iv) que os Estados tenham responsabilidades que permitam que o processo de desenvolvimento se materialize por meio de políticas de desenvolvimento nacionais e internacionais; (v) que haja

\footnotetext{
${ }^{136}$ Alston, 1987, p. 814.

${ }^{137}$ Oliveira, 2005, p. 554.
} 
cooperação internacional entre Estados e instituições internacionais para facilitar a realização desse direito; e (vi) que todas as atividades sejam desempenhadas, com pleno respeito aos direitos civis, políticos, econômicos, sociais e culturais, em razão das interdependência e da indivisibilidade.

Deve-se esclarecer que, a parte deste processo de desenvolvimento previsto na Declaração sobre o Direito ao Desenvolvimento, existem outras diversas formas pelas quais um país pode se desenvolver, seja pelo simples aumento do seu PIB ou pela industrialização interna, entre outras. No entanto, ressalta Sengupta ${ }^{138}$ que esses processos só poderão ser encarados como um processo de desenvolvimento no qual se requer a realização dos direitos humanos, se forem acompanhados de um processo em que haja igualdade de oportunidades. Neste processo de desenvolvimento, a busca pelo crescimento econômico não poderá gerar desigualdades ou aumento da concentração de riquezas e poder econômico, bem como não poderá contribuir para a piora nos indicadores de desenvolvimento social, educação, saúde, proteção ambiental, etc. Mais do que isso as estratégias de crescimento e desenvolvimento econômico deverão obrigatoriamente contribuir para melhorias nesses indicadores, respeitando os padrões de direitos humanos e sem qualquer tipo de violação aos direitos políticos e civis.

Assim, o direito ao desenvolvimento não seria apenas um sumário de todos os direitos humanos, mas mais do que isso é um direito que expande as capacidades ou liberdades dos indivíduos de melhorar seu bem-estar e de realizar o que eles valorizam ${ }^{139}$.

Diante de todo o exposto, pode-se concluir que o direito ao desenvolvimento é um direito humano que engloba a implementação de todos os demais direitos humanos, mas que pode se caracterizar, na prática, como um direito a um processo especial de desenvolvimento, em que todos os direitos humanos devem ser realizados conjuntamente, de maneira que levem em conta seus efeitos uns sobre os outros, de forma a possibilitar o exercício por todos os indivíduos e povos de suas liberdades e capacidades.

\subsubsection{Fundamentos e fontes do direito ao desenvolvimento}

Falar nos fundamentos do direito ao desenvolvimento significa explicar os motivos para a sua criação e sustentação. Ao longo do capítulo anterior e nos itens acima referentes a este capítulo, já foram apresentadas as constatações que levaram à elaboração de um direito humano ao desenvolvimento.

\footnotetext{
${ }^{138}$ Sengupta, 2005, p. 68.

${ }^{139}$ Oliveira, 2005, p. 555.
} 
Apenas por fins didáticos, cumpre neste momento apontá-los de forma conjunta e organizada, como os fundamentos do direito ao desenvolvimento. $\mathrm{Na}$ verdade, esses fundamentos constituem os argumentos e discussões que precederam a redação da Declaração sobre o Direito ao Desenvolvimento.

São diversas as justificativas para o surgimento de um direito ao desenvolvimento. Como bem ressalta Silvia Menicucci de Oliveira ${ }^{140}$, os fundamentos são ecléticos e "abrangem alguns com caráter pragmático e outros emanados da filosofia, da ética, da moral e da religião".

Inicialmente, pode-se dizer que a formação de um direito humano internacional ao desenvolvimento baseou-se em algumas constatações doutrinárias e experimentais e em princípios e normas sólidas do Direito Internacional Público.

Isso porque é evidente que a evolução doutrinária do conceito de desenvolvimento e os acontecimentos históricos ligados ao desenvolvimento da sociedade e da humanidade, como já visto anteriormente, foram fundamentais para o fortalecimento da idéia de um direito humano ao desenvolvimento.

A partir das constatações realizadas com base nos critérios acima, extraíram-se alguns fundamentos do direito ao desenvolvimento, tais como: (i) o crescimento econômico não é suficiente para contribuir para o desenvolvimento, tido como um processo global, que abarca aspectos sociais, culturais e políticos, além de econômicos; (ii) o processo de globalização aproximou as fronteiras e tornou evidente a interdependência entre os países; (iii) as atividades de um Estado no plano internacional interferem nas atividades dos demais países internamente; (iv) existe uma grande desigualdade entre os Estados, (v) a ausência de desenvolvimento pode resultar em violações de direitos humanos.

Conforme já apresentado anteriormente essas constatações incitaram estudiosos, governos e organizações internacionais a buscar alternativas para o conceito de desenvolvimento até então vigente, a fim de que novas regras fossem formuladas para regulamentar as relações internacionais, visando à eliminação das desigualdades evidenciadas e à incorporação de novas e importantes preocupações com o futuro da humanidade. Serviram, ainda, como fundamento para a elaboração da própria Declaração sobre o Direito ao Desenvolvimento, que, em seu preâmbulo, considera que o desenvolvimento é um processo econômico,

\footnotetext{
${ }^{140}$ Oliveira, 2005, p. 518.
} 
social, cultural e político, que busca a constante melhoria do bem-estar de todas as populações e de todos os indivíduos ${ }^{141}$.

Além dessas fontes empíricas e históricas, o direito ao desenvolvimento também possui fundamentos importantes baseados em instrumentos jurídicos previamente existentes no Direito Internacional Público.

Assim, as determinações previstas nos tratados internacionais de direitos humanos, bem como os acordos constitutivos das organizações internacionais, além de regras dos usos e costumes e princípios de direito internacional são fontes jurídicas para a formação de um direito humano ao desenvolvimento.

E isto se pode verificar novamente no preâmbulo da Declaração sobre o Direito ao Desenvolvimento, que relembra os propósitos e princípios da Carta das Nações Unidas relativos à necessidade de cooperação internacional para resolver os problemas internacionais de caráter econômico, social, cultural ou humanitário e para promover e encorajar o respeito aos direitos humanos e às liberdades fundamentais a todos, sem distinção de raça, sexo, língua ou religião, ressaltando-se, ainda, a previsão, neste documento, da obrigação dos Estados de promover o respeito e a observância universais aos direitos humanos e às liberdades fundamentais para todos ${ }^{142}$.

Além disso, faz referência a diversas previsões da Declaração Universal de Direitos do Homem e dos pactos internacionais de direitos humanos, segundo as quais todos têm

\footnotetext{
141 Tradução livre de "Recognizing that development is a comprehensive economic, social, cultural and political process, which aims at the constant improvement of the well-being of the entire population and of all individuals on the basis of their active, free and meaningful participation in development and in the fair distribution of benefits resulting therefrom". Preâmbulo da Declaração sobre o Direito ao Desenvolvimento, 1986.

142 "Bearing in mind the purposes and principles of the Charter of the United Nations relating to the achievement of international co-operation in solving international problems of an economic, social, cultural or humanitarian nature, and in promoting and encouraging respect for human rights and fundamental freedoms for all without distinction as to race, sex, language or religion (...)

Mindful of the obligation of States under the Charter to promote universal respect for and observance of human rights and fundamental freedoms for all without distinction of any kind such as race, colour, sex, language, religion, political or other opinion, national or social origin, property, birth or other status (...) Recognizing that the creation of conditions favourable to the development of peoples and individuals is the primary responsibility of their States (...)". Preâmbulo da Declaração sobre o Direito ao Desenvolvimento, 1986.
} 
direito a uma ordem social e internacional em que os direitos e as liberdades consagradas na Declaração Universal possam ser plenamente realizados ${ }^{143}$.

Ainda, recorda a existência de acordos, convenções, resoluções, recomendações e outros instrumentos da ONU e de suas agências especializadas relativos ao desenvolvimento integral do ser humano, ao progresso econômico e social e ao desenvolvimento de todos os povos, inclusive instrumentos relativos à descolonização (autodeterminação), proibição de discriminação, respeito e observância dos direitos humanos e liberdades fundamentais e manutenção da paz e segurança internacionais ${ }^{144}$.

Assim, pode-se considerar que o direito ao desenvolvimento é uma conseqüência de princípios implícitos e explícitos do Direito Internacional positivo, caracterizando-se como uma norma jurídica dedutível de numerosos instrumentos internacionais, que reflete princípios e valores reconhecidos pela comunidade internacional.

\subsubsection{O Direito do Desenvolvimento}

Ainda no que tange ao conteúdo e origens do direito ao desenvolvimento, convém esclarecer o significado do "direito do desenvolvimento", a fim de sanar possíveis confusões entre os termos.

De certa forma, pode-se dizer que o direito do desenvolvimento faz parte dos antecedentes do direito ao desenvolvimento, contribuindo para o estabelecimento deste direito como direito humano. Isso porque o direito do desenvolvimento é resultado das discussões

\footnotetext{
143 "Considering that under the provisions of the Universal Declaration of Human Rights everyone is entitled to a social and international order in which the rights and freedoms set forth in that Declaration can be fully realized,

Recalling the provisions of the International Covenant on Economic, Social and Cultural Rights and of the International Covenant on Civil and Political Rights (...)". Preâmbulo da Declaração sobre o Direito ao Desenvolvimento, 1986.

144 "Recalling further the relevant agreements, conventions, resolutions, recommendations and other instruments of the United Nations and its specialized agencies concerning the integral development of the human being, economic and social progress and development of all peoples, including those instruments concerning decolonization, the prevention of discrimination, respect for and observance of, human rights and fundamental freedoms, the maintenance of international peace and security and the further promotion of friendly relations and co-operation among States in accordance with the Charter,

Recalling the right of peoples to self-determination, by virtue of which they have the right freely to determine their political status and to pursue their economic, social and cultural development (...)

Considering that the elimination of the massive and flagrant violations of the human rights of the peoples and individuals affected by situations such as those resulting from colonialism, neo-colonialism, apartheid, all forms of racism and racial discrimination, foreign domination and occupation, aggression and threats against national sovereignty, national unity and territorial integrity and threats of war would contribute to the establishment of circumstances propitious to the development of a great part of mankind (...)". Preâmbulo da Declaração sobre o Direito ao Desenvolvimento, 1986.
} 
acerca do conceito de desenvolvimento e das implicações do subdesenvolvimento aos Estados e seus nacionais.

É sabido que o tema do desenvolvimento passa ser enfatizado entre as preocupações da ONU a partir do movimento de descolonização vivenciado nos anos 60 , quando surge uma ideologia do desenvolvimento, resultante da necessidade que passaram a enfrentar os novos países por desenvolvimento econômico e social.

A UNCTAD, conforme já mencionado anteriormente é criada neste período, como resultado da consciência que adquirem os países em desenvolvimento sobre a sua situação de subdesenvolvimento e sobre as condições estruturais internacionais, passando a exigir da comunidade internacional, em especial dos países desenvolvidos, maior atenção aos seus problemas. A UNCTAD serviu, portanto, de quadro institucional para as reivindicações ligadas ao desenvolvimento.

No âmbito dos debates realizados pela UNCTAD, foi criado um regime de exceção para compensar as desigualdades econômicas existentes entre as nações, que passou a ser conhecido pela doutrina como Direito Internacional do Desenvolvimento ${ }^{145}$.

Assim, o Direito do Desenvolvimento é concebido como um ramo do Direito Internacional, voltado a solucionar os problemas singulares dos países em desenvolvimento e a veicular as demandas referentes ao estabelecimento de uma nova ordem econômica internacional ${ }^{146}$. Este novo ramo, na verdade, é uma expressão da necessidade de um tratamento desigual para países em situações distintas a fim de eliminar as desigualdades existentes entre eles ${ }^{147}$.

Neste sentido, afirma Antônio Augusto Cançado Trindade ${ }^{148}$ que o direito do desenvolvimento quer regularizar as relações entre Estados juridicamente iguais, mas economicamente desiguais, almejando, assim, a transformação dessas relações, por meio

\footnotetext{
${ }^{145}$ Perrone-Moisés, 1998, p. 48.

146 Oliveira, 2005, p. 510.

${ }^{147} \mathrm{O}$ direito do desenvolvimento é, portanto, resultado do enfraquecimento do princípio da igualdade formal como norteador da justiça. Assim, diante da nova regra, que ressalta a necessidade de tratamento desigual aos desiguais, só se considera justa uma ordem econômica internacional que respeite a desigualdade entre os países, concedendo maiores prerrogativas aos Estados que se encontram em um grau mais baixo de desenvolvimento. Assim, pode-se dizer que o direito do desenvolvimento é o fundamento da criação do Sistema Geral de Preferências do GATT, por exemplo, que confere a possibilidade de tratamento diferenciado aos países em desenvolvimento, como exceção ao princípio da cláusula da nação favorecida, que será estudado posteriormente no presente trabalho.

${ }^{148}$ Trindade, 1993, p. 176.
} 
da cooperação internacional. Assim, segundo o autor, o direito do desenvolvimento englobaria diversas condições, tais como: (i) o direito a autodeterminação econômica; (ii) a soberania permanente sobre as riquezas e os recursos naturais; (iii) o princípio do tratamento não-recíproco e preferencial para os países em desenvolvimento; e (iv) o princípio da igualdade participatória dos países em desenvolvimento nas relações econômicas internacionais e nos benefícios da ciência e da tecnologia.

Vale dizer, portanto, que o direito do desenvolvimento surge também como uma crítica ao modelo de Direito Internacional vigente à época, sendo que alguns autores o encaram não como um ramo do Direito Internacional, mas como a sua renovação ${ }^{149}$.

De qualquer forma, o direito do desenvolvimento deu maior ênfase à necessidade dos Estados menos desenvolvidos de se desenvolverem economicamente para que pudessem solucionar seus problemas internos, exigindo-se assim que lhes fosse permitido pelos países desenvolvidos possuir maior participação nas relações econômicas internacionais.

Note-se, porém, que o direito do desenvolvimento não logrou colocar o desenvolvimento como principal objetivo e preocupação da comunidade internacional, vez que buscava seu enfoque era dado ao direito dos Estados subdesenvolvidos de verem suas reivindicações atendidas, ou seja, visava à conceder maior legitimidade às exigências governamentais.

Já o direito ao desenvolvimento vem romper com este enfoque nos Estados, como resultado dos esforços pela aproximação entre a questão do desenvolvimento e os direitos humanos, complementando, assim, os objetivos perseguidos pelo direito do desenvolvimento.

Assim, como bem lembra Cláudia Perrone Moisés ${ }^{150}$ :

Enquanto a questão do desenvolvimento vai perdendo força nos anos 80, com o esvaecimento das discussões interestatais, em torno dos conflitos Norte-Sul; o trabalho em torno de sua concretização se desenvolve no foro dos direitos humanos, onde a questão do desenvolvimento já havia sido inserida como herança da Nova Ordem Econômica Internacional.

149 Para Celso D. de Albuquerque Mello, por exemplo, entende que o Direito Internacional do Desenvolvimento é uma crítica ao Direito Internacional efetuada pelos internacionalistas e tem como objetivo substituir o Direito Internacional clássico por meio de seus próprios instrumentos (1993, p. 10). Na mesma linha, Mohamed Bennouna considera o Direito Internacional do Desenvolvimento como uma forma de interpelação ou de questionamento (1983, p. 17-19). 
Assim, enquanto o direito do desenvolvimento era concebido para ser fundamentalmente interestatal, o direito ao desenvolvimento, sendo um direito humano de titularidade coletiva contempla nações, povos e indivíduos.

\subsubsection{A natureza jurídica do direito ao desenvolvimento}

A natureza jurídica do direito ao desenvolvimento em muito reflete as considerações feitas acima sobre seus fundamentos. Isso porque representa, em verdade, a sua situação normativa dentro do Direito Internacional, o que quer dizer que a sua natureza jurídica é resultado do seu grau de normatividade jurídico-internacional como um direito humano.

E assim como os demais aspectos do direito ao desenvolvimento, determinar a situação jurídica em que se encontra esse direito no plano internacional não poderia deixar de ser um ponto controvertido.

Conforme já apresentado anteriormente, o estabelecimento do direito ao desenvolvimento como direito humano não foi uma batalha fácil e rápida, tendo exigido grandes esforços de seus defensores no plano internacional para que finalmente se possa dizer hoje que sua natureza como direito encontra-se aceita pela comunidade internacional ${ }^{151}$.

Apesar disso, ainda é bastante controvertida a discussão atualmente sobre a força normativa do direito ao desenvolvimento como direito humano. Isso porque este direito não está previsto de modo expresso em nenhum tratado internacional ${ }^{152}$, restringindo-se a instrumentos internacionais que, em regra, não são aceitos como detentores de força vinculante, como as resoluções da Assembléia Geral e da Comissão de Direitos Humanos da ONU.

\footnotetext{
${ }^{150}$ Perrone-Moisés, 1999, p. 186.

151 Lembre-se o consenso da Declaração de Viena, de 1993, que reafirmou o direito ao desenvolvimento como direito humano.

${ }^{152}$ Existe uma única exceção em âmbito regional, que consiste na expressa menção ao direito ao desenvolvimento na Carta Africana de Direitos Humanos e dos Povos (Carta de Banjul, aprovada pela Conferência Ministerial da Organização da Unidade Africana (OUA) em Banjul, Gâmbia, em janeiro de 1981, e adotada pela XVIII Assembléia dos Chefes de Estado e Governo da OUA em Nairóbi, Quênia, em 27 de julho de 1981). O preâmbulo da Carta de Banjul dispõe que estão: "Convencidos de que, para o futuro, é essencial dedicar uma particular atenção ao direito ao desenvolvimento (...)", enquanto o seu artigo 22 determina:

"1.Todos os povos têm direito ao seu desenvolvimento econômico, social e cultural, no estrito respeito da sua liberdade e da sua identidade, e ao gozo igual do patrimônio comum da humanidade. 2.Os Estados têm o dever, separadamente ou em cooperação, de assegurar o exercício do direito ao desenvolvimento". Texto em português disponível em: <http://www.dhnet.org.br/direitos/sip/africa/banjul.htm>. Acesso em: 04 jan. 2009.
} 
Segundo Silvia Menicucci de Oliveira ${ }^{153}$, esse contexto permite identificar duas correntes gerais sobre a situação jurídica do direito ao desenvolvimento: (i) a primeira entendendo que o seu status de direito deriva dos instrumentos nos quais constam seus possíveis fundamentos, cuja força vinculante é transferida ao direito ao desenvolvimento; (ii) a segunda, por sua vez, parte da afirmação do direito ao desenvolvimento per se e considerao independentemente de instrumentos normativos nos quais são identificados seus fundamentos, o que contribuiria com o aumento da eficácia das resoluções da Assembléia Geral e da Comissão de Direitos Humanos das Nações Unidas.

A primeira linha, portanto, reconhece que os instrumentos internacionais que reconhecem o direito ao desenvolvimento carecem de força vinculante, porém os fundamentos que embasam a sua caracterização como direito humano estão previstos em tratados internacionais de caráter convencional, como a Carta das Nações Unidas, a Declaração Universal dos Direitos do Homem e os pactos internacionais de direitos humanos.

Nesta linha, encontram-se também aqueles doutrinadores que entendem que as normas internacionais de direitos humanos são regras do ius cogens, ou seja, são normas jurídicas que não admitem derrogação e só podem ser modificadas por nova norma de Direito Internacional geral da mesma natureza ${ }^{154}$.

Quanto ao posicionamento da segunda corrente, cumpre ressaltar que trata-se de uma vertente doutrinária que questiona a regra internacional tradicional no que tange à força vinculante dos instrumentos jurídicos internacionais. Assim, conforme o entendimento adotado sobre a formação do Direito Internacional, pode-se conceder maior ou menos grau de normatividade ao direito ao desenvolvimento.

De acordo com este entendimento, o Direito Internacional não se restringiria ao processo tradicional de formação das normas jurídicas, mas vai além e busca técnicas alternativas, tais como as resoluções das organizações internacionais. Isso porque uma vez que os Estados Membros de uma organização internacional ratificam sua condição de membro pela assinatura e incorporação do tratado constitutivo em seus ordenamentos internos, deve-se pressupor que a soberania e a vontade desses Estados também é representada pelas decisões proferidas no âmbito da organização internacional da qual fazer parte.

\footnotetext{
${ }^{153}$ Oliveira, 2005, pp. 525-534.

${ }^{154}$ Sobre a relação entre o direito ao desenvolvimento e o Ius Cogens, ver Bedjaoui, 1985, p. 48-55.
} 
Assim, como bem ressalta Georges Abi-Saab ${ }^{155}$, apesar da situação formal das resoluções da Assembléia Geral ser de mera recomendação, situação esta atribuída pela Carta das Nações Unidas, há alguns indícios práticos de que podem lhes atribuir um caráter jurídico mandatório, dependendo do valor social sobre o qual deliberam. Assim, o grau de consenso obtido no corpo político sobre o valor social em questão, o grau de operacionalidade do conteúdo desse valor social e a existência de um mecanismo de acompanhamento de sua observância podem conferir maior efetividade às resoluções.

E ainda convém ressaltar os ensinamentos do professor Fábio Konder Comparato ${ }^{156}$, para quem o caráter não vinculante das recomendações, como as resoluções da Assembléia Geral da ONU "significa tão-só a ausência de sanções internacionais contra os Estados que descumprem tais recomendações. Mas estas expressam, inequivocamente, a consciência jurídica internacional a respeito das matérias nela tratadas, contribuindo, portanto, como já foi observado, para a formação do direito costumeiro internacional".

Assim, segundo esta corrente, a tendência é admitir o direito ao desenvolvimento com algum status jurídico no Direito Internacional contemporâneo, relacionada à capacidade legislativa ou quase legislativa da Assembléia Geral da ONU. Assim, a Declaração sobre o Direito ao Desenvolvimento seria considerada uma nova fonte de Direito Internacional e teria força normativa suficiente para ser "transformada" em direito costumeiro ou tratado internacional ou para evidenciar princípios gerais de direito ${ }^{157}$.

Apesar de todos esses esforços, há ainda uma tendência a admitir o direito ao desenvolvimento apenas como uma obrigação moral e não jurídica, tratando-se seu conteúdo apenas de recomendações aos Estados, que deverão inspirar a formulação de disposições efetivamente jurídicas. Deve-se, no entanto, ater-se aos princípios de um Direito Internacional de cooperação, no qual às normas flexíveis (Soft Law) também deve ser atribuída força normativa vinculante.

Por fim, cumpre ainda observar uma abordagem alternativa a que faz referência Silvia Menicucci de Oliveira ${ }^{158}$, na qual passa-se a debater não a situação jurídica do direito ao

\footnotetext{
${ }^{155}$ Abi-Saab, 1979, p. 160-162.

${ }^{156}$ Comparato, 1998, p.647.

157 Oliveira, 2005, p. 530.

${ }^{158}$ Oliveira, 2005, p. 532-534.
} 
desenvolvimento, mais sim seus efeitos jurídicos, segundo a metodologia de Obiora Okafor $^{159}$.

De acordo com essa nova metodologia, apesar do status formalmente não obrigatório da Declaração sobre o Direito ao Desenvolvimento e de outras resoluções, os efeitos por elas gerados nas relações normativas entre os Estados é bastante significativo, atribuindo-lhes enorme importância. Isso porque o direito ao desenvolvimento, conforme previsto, nesses instrumentos, pode inspirar a elaboração e a codificação do Direito Internacional em diversas áreas.

Assim, identificam-se três principais efeitos jurídicos possíveis do direito ao desenvolvimento. $\mathrm{O}$ primeiro deles diz respeito à possibilidade de o direito ao desenvolvimento gerar direito, já que pode resultar em um tratado ou se tornar princípio geral de Direito. Além disso, as disposições da Declaração sobre o Direito ao Desenvolvimento e demais resoluções sobre o tema podem contribuir para a incorporação de regras novas a tratados já existentes, como é o caso do princípio do tratamento diferenciado aos países em desenvolvimento.

$\mathrm{O}$ segundo possível efeito refere-se à capacidade desses instrumentos de regular e estabelecer parâmetros para a criação do Direito. Isso significa que as resoluções sobre direito ao desenvolvimento possuem extrema importância porque limitam o que deve ou não se tornar Direito e definem como as normas existentes e as futuras deverão ser interpretadas.

Por fim, o terceiro efeito diz respeito à capacidade das normas sobre direito ao desenvolvimento de legitimar e deslegitimar o Direito. Inicialmente, convém esclarecer que, para Okafor, a legitimidade refere-se à sua capacidade de ser aceita e efetiva, ou seja, de ser colocada em prática, de forma mais voluntária do que forçada, ou seja, sem depender tanto dos instrumentos de coerção que as normas jurídicas carregam em geral.

Dessa forma, uma determinação não mandatória teria maior capacidade de legitimar o Direito quando por seu conteúdo facilitasse a aceitação de regras jurídicas vinculantes préexistentes ou emergentes. Como exemplo, pode-se dizer que as disposições sobre o direito ao desenvolvimento legitimam os demais direitos humanos, como o direito à educação.

${ }^{159}$ Okafor, 1995 , p. $865-867$ e $881-885$. 
Por outro lado, diz-se que os dispositivos sobre o direito ao desenvolvimento possuem um papel deslegitimador no que se refere à sua capacidade de afastar a aplicação prática de uma norma. Assim, a incorporação do princípio do tratamento diferenciado aos países em desenvolvimento seria uma expressão da deslegitimação das normas fundadas na igualdade formal de todos os Estados.

Percebe-se, portanto, que, apesar de controvérsia no que tange à natureza ou situação jurídica das disposições sobre o direito ao desenvolvimento, é evidente que: (i) suas fontes e fundamentos estão consolidados no Direito Internacional; (ii) a evolução do Direito Internacional contemporâneo contribui para uma maior efetividade às normas consideradas tradicionalmente não vinculantes; e (iii) elas certamente causam efeitos nas normas e princípios mandatórios de Direito Internacional. Não há dúvidas, portanto, da importância jurídica do reconhecimento do direito ao desenvolvimento no plano internacional.

\subsubsection{Os sujeitos do direito ao desenvolvimento}

O caráter de direito humano do direito ao desenvolvimento já permite pressupor que seu sujeito central é o próprio indivíduo, vez que essa é uma das características intrínsecas dos direitos humanos: garantir algo e protegê-lo a todos os indivíduos, com vistas a uma vida digna.

Assim, uma vez que o direito ao desenvolvimento já foi reconhecido como direito humano, não há dúvidas de que todos os seres humanos são titulares deste direito. No entanto, a Declaração sobre o Direito ao Desenvolvimento reconhece ainda neste direito uma dimensão coletiva, afirmando tratar-se de um direito dos povos, como coletividade. Além disso, a Declaração também reconheceu a importância do direito de auto-determinação dos povos, afirmando que este direito implica o exercício do direito inalienável de ter soberania sobre suas riquezas e recursos naturais ${ }^{160}$.

$\mathrm{Na}$ verdade, desde as primeiras manifestações da ONU que reconheceram o direito ao desenvolvimento como direito humano, já se verifica uma dimensão coletiva atribuída a este direito, uma vez que afirma-se que a igualdade de oportunidade para o desenvolvimento é uma prerrogativa tanto das nações como dos indivíduos que compõem as nações.

\footnotetext{
${ }^{160}$ Artigo $1^{\circ}$, da Declaração sobre o Direito ao Desenvolvimento.
} 
Esse reconhecimento do direito ao desenvolvimento também como um direito coletivo é bastante controverso, sendo que diversos países (desenvolvidos, na maioria) e estudiosos negaram a existência de uma dimensão coletiva no direito ao desenvolvimento, especialmente por não reconhecer a existência de direitos humanos coletivos em geral.

No entanto, conforme os ensinamentos de Arjun Sengupta, é perfeitamente lógica que haja uma pressão pela consideração dos direitos humanos como direitos coletivos, ainda que seja necessária cautela para definir corretamente o que são direitos humanos coletivos, que não se opõem aos direitos individuais. Esses direitos não devem ser vistos como superiores aos direitos individuais ${ }^{161}$.

Isso porque, há que se ter em mente que o sujeito central do direito humano ao desenvolvimento é o indivíduo, que deve ser participante ativo e beneficiário deste direito, conforme atesta a Declaração sobre o Direito ao Desenvolvimento ${ }^{162}$. Dessa forma, o desenvolvimento do ser humano deve ser o principal objetivo de se garantir e proteger o direito ao desenvolvimento.

A diferença entre os direitos humanos individuais e os coletivos estaria basicamente nos detentores do direito e não nos seus beneficiários. Assim, enquanto no caso dos direitos individuais, o titular do direito é também o próprio beneficiário do seu exercício, nos direitos coletivos, o titular do direito pode ser pode ser uma coletividade, como uma nação, mas o beneficiário do exercício deste direito deve sempre ser o ser humano ${ }^{163}$.

Como ressalta o professor Fábio Konder Comparato ${ }^{164}$, “deparamo-nos aí com a figura jurídica que as correntes privatistas e processualistas denominam substituição: alguém é autorizado pela ordem jurídica a exercer, em seu próprio nome, direitos e pretensões pertencentes a outrem".

O reconhecimento de um caráter coletivo ao direito ao desenvolvimento, portanto, deve manter ainda o desenvolvimento dos indivíduos como resultado final a ser alcançado. Assim, o aspecto coletivo do direito ao desenvolvimento nada mais é, em última instância, do que mais uma garantia - e uma garantia necessária - para a realização do direito individual ao desenvolvimento.

\footnotetext{
${ }^{161}$ Sengupta, 2005, p. 79.

${ }^{162}$ Artigo $2^{\circ}$, da Declaração sobre o Direito ao Desenvolvimento.

163 Sengupta, 2005, p. 79-80.

${ }^{164}$ Comparato, 1998, p. 651.
} 
Como bem ressalta Silvia Menicucci de Oliveira ${ }^{165}$ :

Por um lado, um direito ao desenvolvimento considerado como direito dos povos, que não levasse em conta sua dimensão individual, não refletiria o conceito dado ao desenvolvimento pela Declaração. Por outro lado, um direito ao desenvolvimento concebido exclusivamente como um direito individual suporia desconhecer que determinado direitos humanos individuais são ilusórios em uma estrutura internacional que perpetua condições desfavoráveis ao desenvolvimento dos povos.

O próprio Direito Internacional dos Direitos Humanos, como observa Keba M'Baye ${ }^{166}$, também concedeu direito a grupos de indivíduos. Os grupos são povos e nações. Em geral, são os Estados, como representantes daquelas entidades, difíceis de serem identificadas, que exercem os direitos pertencentes a eles.

Conclui-se, portanto, perfeitamente possível tratar-se do direito ao desenvolvimento como um direito de dimensões individual e coletiva, como um direito de indivíduos e de coletividades.

Uma vez que os direitos humanos visam a dar condições indispensáveis para que o indivíduo tenha uma vida plenamente digna, pode ocorrer que tais condições incluam a necessidade de se atender a interesses de uma coletividade de seres humanos, como é o caso do direito ao desenvolvimento.

De fato, em muitos casos, direitos individuais somente podem ser satisfeitos em um contexto coletivo, e o direito de um Estado ou nação se desenvolver torna-se condição necessária para o cumprimento dos direitos e para a realização do desenvolvimeto dos indivíduos ${ }^{167}$.

Ressalte-se, mais uma vez, que a Declaração sobre o Direito ao Desenvolvimento menciona diversas vezes as "os povos" como sujeitos de direitos, além de utilizar termos como "nações", "grupos” e "populações".

O Estado, por sua vez, consiste em uma forma de organização de uma nação ou dos povos e, ainda que não seja mencionado explicitamente na Declaração como sujeito do direito ao desenvolvimento, esta reconhece aos Estados o direito e o dever de adotar políticas

\footnotetext{
165 Oliveira, 2005, p. 535.

${ }^{166}$ M'Baye, 1991, p. 1049.

${ }^{167}$ Sengupta, 2005, p. 80.
} 
públicas de desenvolvimento que permitam a realização das capacidades de todo indivíduo e do bem-estar de todas as populações ${ }^{168}$.

Segundo Maria Magdalena Kenig Witkowska ${ }^{169}$, apesar da ausência de clareza na Declaração sobre o Direito ao Desenvolvimento, quanto ao papel dos Estados no que tange ao direito ao desenvolvimento, uma análise aprofundada dos seus trabalhos preparatórios na ONU permite aferir, sem dúvidas, que o Estado é sujeito do direito ao desenvolvimento na sua dimensão coletiva.

No entanto, este debate permanece polêmico, não havendo posicionamento dominante na comunidade internacional que determine se os Estados são ou não sujeitos do direito ao desenvolvimento.

A Declaração sobre o Direito ao Desenvolvimento reconhece, porém, que o Estado é uma "estrutura política necessária na mediação entre a sociedade internacional de um lado e os povos e indivíduos do outro" $" 170$.

Neste sentido, destaca Comparato ${ }^{171}$, "O Estado nada mais é do que o status de um povo, unificado politicamente. O verdadeiro titular do interesse, nas relações protagonizadas pelos Estados, ou seja, a parte em sentido material, é, portanto, sempre o povo".

No entanto, como bem lembra Bedjaoui ${ }^{172}$, o direito ao desenvolvimento é proclamado em um sistema que opera entre Estados, ou seja, um sistema no qual a prática interestatal é, por enquanto, inevitável, uma vez que é tipicamente reconhecida como a principal prática do Direito Internacional e de suas instituições.

Dessa forma, considerar somente a dimensão individual do direito ao desenvolvimento torna-o limitado ao âmbito nacional em razão da lógica do atual sistema internacional. Uma vez que os problemas nacionais possuem uma dimensão internacional, se um Estado procurasse garantir a realização do direito ao desenvolvimento em seu território, encontraria diversos obstáculos no ambiente internacional que dificultariam ou tornariam inúteis seus esforços.

\footnotetext{
${ }^{168}$ Artigo $2^{\circ}$, parágrafo $3^{\circ}$, da Declaração sobre o Direito ao Desenvolvimento.

${ }^{169}$ Witkowska, 1988, p. 382.

${ }^{170}$ Oliveira, 2005, p. 538.

${ }^{171}$ Comparato, 1998, p. 652.

172 Bedjaoui, 1985, p. 45-47.
} 
Assim, fica evidente que as dimensões coletiva e individual do direito ao desenvolvimento são indissociáveis, já que em uma ordem econômica não favorável, torna-se extremamente difícil fornecer as prestações e serviços requeridos pelos direitos humanos na sua dimensão individual, ou seja, a estrutura atual do Direito Internacional, baseada na soberania estatal, retira qualquer possível efetividade do direito ao desenvolvimento, se desconsiderada sua dimensão coletiva.

A própria Declaração sobre Direito ao Desenvolvimento prevê que a promoção e proteção dos direitos humanos só serão alcançadas diante de uma ordem econômica, política e social no âmbito internacional que busque e permita o desenvolvimento dos países ${ }^{173}$.

De qualquer forma, ainda que não se entenda o Estado como titular do direito ao desenvolvimento, o fato é que terá legitimidade para pleitear mudanças na ordem econômica internacional vigente a fim de obter maior participação e assim, poder garantir o exercício de um direito humano.

Somente o reconhecimento da dimensão coletiva do direito ao desenvolvimento permitirá que, na prática, possa se exigir do Estado suas responsabilidades pela realização do direito ao desenvolvimento, conforme será explicitado no item seguinte.

Deve-se ressaltar, por fim, que as disposições da Declaração sobre o Direito ao Desenvolvimento não pretendem desconsiderar a primazia dos direitos individuais, mas buscam complementá-los com os direitos coletivos a fim de dar maior efetividade aos direitos humanos.

\subsubsection{A responsabilidade do Estado e o papel da cooperação internacional}

Restou evidente, como bem coloca a professora Cláudia Perrone Moisés, que, no tocante ao direito ao desenvolvimento em sua dimensão internacional, estão presentes as seguintes premissas:

\footnotetext{
${ }^{173} \mathrm{O}$ artigo 2, itens 2 e 3 da Declaração sobre o Direito ao Desenvolvimento dispõem que:

"2. All human beings have a responsibility for development, individually and collectively, taking into account the need for full respect for their human rights and fundamental freedoms as well as their duties to the community, which alone can ensure the free and complete fulfillment of the human being, and they should therefore promote and protect an appropriate political, social and economic order for development. 3. States have the right and the duty to formulate appropriate national development policies that aim at the constant improvement of the well-being of the entire population and of all individuals, on the basis of their active, free and meaningful participation in development and in the fair distribution of the benefits resulting therefrom". Nesse mesmo sentido, o artigo 3 também ressalta a importância de uma nova ordem econômica internacional e determina o dever dos Estados e da sociedade internacional de promover o direito ao desenvolvimento pela implantação de um sistema econômico apropriado para a concretização desses objetivos.
} 
a) o desenvolvimento de qualquer país depende hoje, mais do que nunca, do plano internacional; b) o crescente reconhecimento da interdependência das sociedades, devido a contatos transnacionais, leva à necessidade de uma aproximação global dos problemas ligados ao desenvolvimento; e c) o desenvolvimento global enfrenta problemas transnacionais econômicos que se expressam por meio de modelos de dominação e dependência, em relações comerciais desvantajosas e na concentração do poder dos operadores econômicos transnacionais privados.

Dessa forma, torna-se imperativo que tanto os Estados como a própria comunidade internacional tenham responsabilidades determinadas na busca pela realização do direito ao desenvolvimento, lembrando-se que "os direitos humanos, em razão de sua universalidade nos planos tanto normativo como operacional, acarretam obrigações erga omnes" ${ }^{" 174}$.

É bem de ver que a Declaração sobre o Direito ao Desenvolvimento ${ }^{175}$ estabelece que os Estados têm a responsabilidade primária pela criação das condições nacionais e internacionais favoráveis à realização do direito ao desenvolvimento, sendo essencial que busquem elaborar, adotar e implementar políticas públicas de desenvolvimento.

Silvia Menicucci de Oliveira ${ }^{176}$ destaca ainda outras responsabilidades dos Estados previstas na Declaração de 1986, fundamentais à realização do direito ao desenvolvimento:

Os Estados devem assegurar, inter alia, igualdade de oportunidade para todos no acesso aos recursos básicos, educação, serviços de saúde, alimentação, habitação, emprego e distribuição equitativa de renda. Medidas efetivas também devem ser tomadas para assegurar que as mulheres tenham um papel ativo no processo de desenvolvimento, e reformas econômicas e sociais apropriadas devem ser efetuadas com vistas à erradicação de todas as injustiças sociais. Além disso, na redação do artigo $8^{\circ}$, os Estados devem encorajar a participação popular em todas as esferas como um fator importante no desenvolvimento e na plena realização de todos os direitos humanos.

Apesar de reconhecer a responsabilidade primária dos Estados pelo direito ao desenvolvimento, a Declaração sobre o Direito ao Desenvolvimento também ressalta que a comunidade internacional tem o dever de cooperar para permitir que os Estados cumpram com suas obrigações.

Um momento significativo para o fortalecimento do princípio da cooperação pelo desenvolvimento é a criação do PNUD - Programa das Nações Unidas para o Desenvolvimento, em 1961, que reconheceu o desenvolvimento como problema global, que só poderia ser solucionado por meio da solidariedade internacional.

\footnotetext{
174 Trindade, 1994, p. 184.

175 Artigos $3^{\circ}$ e 10 da Declaração sobre o Direito ao Desenvolvimento.

176 Oliveira, 2005, p. 544.
} 
Já em 1970, a Assembléia Geral da ONU deu novo impulso ao princípio da cooperação, estabelecido na Carta das Nações Unidas, ao adotar a Declaração dos Princípios de Direito Internacional referentes às Relações de Amizade e de Cooperação entre os Estados, por meio da Resolução 2625 (XXV) ${ }^{177}$. Nesta ocasião, reafirmou-se a obrigação dos Estados de cooperar entre si nas esferas econômica, social e cultural, além do dever de todos os Estados de promover o crescimento econômico em todo o mundo, particularmente nos países em desenvolvimento ${ }^{178}$.

Tornava-se evidente, desde então, que as questões relacionadas ao desenvolvimento levantam uma série de problemas e desafios à comunidade internacional. Dessa forma, essas questões só podem ser tratadas por meio da solidariedade internacional para que se possa alcançar resultados positivos no que tange à realização e à implementação do direito ao desenvolvimento nos planos interno e internacional.

Não há dúvidas, portanto, de que a cooperação internacional exerce papel fundamental no direito ao desenvolvimento. Isso porque já é sabido que a atuação de um Estado no cenário internacional, em especial, no tocante às suas relações econômicas e comerciais internacionais, é fundamental para o seu desenvolvimento interno e, é mais clara ainda a noção de que para que um indivíduo possa se desenvolver é necessário que sua nação se desenvolva simultaneamente.

Assim, os Estados devem cooperar uns com os outros para assegurar o desenvolvimento e eliminar os obstáculos à realização do direito ao desenvolvimento. A Declaração de Viena $^{179}$ de 1993 destacou a importância da cooperação entre os Estados pelo desenvolvimento e ressaltou que a comunidade internacional deve promover uma cooperação internacional eficaz, visando à realização do direito ao desenvolvimento. $\mathrm{O}$ progresso duradouro necessário à realização do direito ao desenvolvimento exige políticas eficazes de desenvolvimento em nível nacional, bem como relações econômicas equitativas e um ambiente econômico favorável em nível internacional.

Dessa forma, pode-se dizer que a comunidade internacional, por meio dos instrumentos que prevêem o direito internacional como direito humano, reconheceu que o grau de participação de um país nas relações internacionais, em particular para o presente estudo,

\footnotetext{
${ }^{177}$ A Resolução 2625 (XXV), da Assembléia Geral da ONU foi adotada em 24 de outubro de 1970.

${ }^{178}$ Oliveira, 2005, p. 511.

${ }^{179}$ Parágrafo 10, da Declaração de Viena.
} 
nas relações comerciais, pode representar maior ou menor condição de promoção e implementação do direito ao desenvolvimento aos seus nacionais. Por esse motivo, as regras do comércio internacional devem ser definidas e estudadas em atenção à busca pela implementação do direito ao desenvolvimento em todos os países. Isso significa que as leis de livre mercado, sem qualquer preocupação com o desenvolvimento, não hão de ser regras promotoras do direito ao desenvolvimento como direito humano e, portanto, não devem ser mantidas.

A UNCTAD, conforme mencionado no capítulo anterior, serviu fortemente ao reconhecimento da necessidade de cooperação internacional nas relações econômicas internacionais, fundamentando-se especialmente na responsabilidade da comunidade internacional pelo desenvolvimento. Ainda que não tenha obtido resultados práticos mais recentemente e que não tenha alcançado os objetivos ambiciosos que buscava quando de sua criação, contribuiu e vem contribuindo com o direito ao desenvolvimento por meio de seus estudos, recomendações e servindo como aliada ao discurso de que a busca pelo direito ao desenvolvimento é uma obrigação de todos os Estados e da comunidade internacional.

Diante deste cenário, conclui-se que somente a busca por regras de comércio que levem em consideração as diferenças econômico-sociais entre os países participantes do comércio internacional, corresponderá aos objetivos da Declaração sobre Direito ao Desenvolvimento e do próprio tratado constitutivo da ONU. E, somente um comércio internacional que respeite e promova o direito ao desenvolvimento como direito humano poderá ser considerado um comércio justo e, portanto, aceitável.

Assim, qualquer relacionamento entre os países deverá pressupor métodos de alcance desse objetivo desenvolvimentista para que se possa dizer que tratam-se de relações justas. A ausência de medidas garantidoras ou fomentadoras do direito ao desenvolvimento só pode ser encarada como injustiça nas relações internacionais.

\subsection{A EDUCAÇÃO E O DIREITO AO DESENVOLVIMENTO}

Para finalizar este capítulo, mister uma breve análise da relação entre a educação e o direito ao desenvolvimento como direito humano.

A própria Declaração sobre o Direito ao Desenvolvimento dispõe sobre as medidas necessárias para a realização do direito ao desenvolvimento e, entre elas, afirma a 
obrigatoriedade dos Estados de assegurar a igualdade de oportunidade para todos quanto ao acesso à educação, reconhecendo, assim, que a realização do direito ao desenvolvimento depende do estado em que se encontra a implementação dos princípios educacionais internacionais.

Conscientes disso, aos oito de setembro de 2000, os chefes de Estado e de governo dos Estados membros da ONU proclamaram a Declaração do Milênio e estabeleceram oito objetivos os quais se comprometeram a concretizar até 2015 para que o direito ao desenvolvimento fosse realizado no mundo.

A Declaração do Milênio nada mais é do que uma histórica reafirmação dos propósitos e princípios da Carta das Nações Unidas de 1948, que se mostraram atemporais e universais e da conseqüente obrigação de promover a democracia e fortalecer o império dos direitos humanos e liberdade fundamentais internacionalmente reconhecidos, incluindo o direito ao desenvolvimento. ${ }^{180}$

Entre os objetivos para o desenvolvimento do milênio, o segundo refere-se à garantia da educação primária para todos. Dessa forma, a comunidade e o direito internacional reafirmam as disposições da Declaração sobre o Direito ao Desenvolvimento e reconhecem a importância da educação para o desenvolvimento.

Neste sentido, Agostinho dos Reis Monteiro afirma que ${ }^{181}$ :

se o sentido do direito ao desenvolvimento deve ser o desenvolvimento da pessoa humana, a chave do desenvolvimento, na sua dimensão individual e coletiva, cultural, política, econômica, ecológica, está no direito à educação. É o mais fundamental dos direitos para uma vida humana, tanto para as gerações presentes como para as gerações futuras.

Portanto, resta evidente que o direito ao desenvolvimento, entendido tanto como direito síntese, como direito a um processo particular de desenvolvimento, não pode prescindir de altos índices no acesso e na qualidade da educação para que se possa falar na implementação e cumprimento deste direito.

Isso porque ao longo deste capítulo, notou-se que o direito ao desenvolvimento engloba a proteção e garantia do direito à educação, como um dos direitos humanos fundamentais para a realização do direito ao desenvolvimento.

\footnotetext{
${ }^{180}$ Parágrafos 3 e 24 da Declaração do Milênio.

${ }^{181}$ Monteiro, 2003, p. 785 e 786.
} 
Assim, para um melhor entendimento do impacto do comércio internacional de serviços educacionais para o direito ao desenvolvimento, é fundamental estudar a realidade do direito à educação, objeto do próximo capítulo. 


\section{III - O DIREITO À EDUCAÇÃO}

Visto que o direito ao desenvolvimento é um direito que engloba diversos outros direitos humanos, entre eles o direito à educação, foi possível afirmar que a verdadeira realização do direito ao desenvolvimento só pode ser alcançada com avanços significativos na proteção e garantia do direito à educação como um direito humano.

O presente capítulo objetiva apresentar, portanto, o que é a educação, a sua evolução no direito internacional dos direitos humanos, a sua importância para o desenvolvimento e o seu tratamento no Brasil, com especial ênfase na educação superior, visto que este é o setor educacional "negociado" atualmente na OMC.

\subsection{A EDUCAÇÃO COMO DIREITO: CAMINHOS PARA O DESENVOLVIMENTO}

Inicialmente, cumpre esclarecer que a conceituação da educação no presente trabalho volta-se predominantemente para o seu tratamento jurídico.

É evidente que a ciência da educação é bastante complexa e perpassa diversos aspectos que adentram outras ciências, como o direito, a filosofia, a sociologia, a antropologia, a ciência política, a economia, entre outras, que dão à educação um caráter multidisciplinar indispensável para a verdadeira compreensão de sua importância para os indivíduos, sociedades, Estados e para a humanidade.

Dessa forma, a busca por um conceito de educação torna-se bastante difícil, para não dizer impossível, quando se tem em vista uma denominação que englobe todos estes fatores. Por este motivo, para o presente feito, tratar-se-á de um conceito jurídico de educação, com vistas, portanto, à realização do direito à educação como um direito humano, antes de mais nada.

Essa delimitação em sua conceituação não quer excluir deste trabalho a preocupação com a educação em todas as suas dimensões, ou seja, o fato de conceituar-se a educação juridicamente não altera o fato de que este trabalho quer demonstrar a preocupação com o direito a uma educação completa, que contribua ao desenvolvimento social, político, econômico, antropológico, filosófico do homem ${ }^{182}$.

\footnotetext{
${ }^{182}$ Neste sentido, Agostinho dos Reis Monteiro afirma que a importância da educação se dá nos âmbitos: (i) antropológico, pois o ser humano não nasce adulto, tendo real necessidade da educação para o seu
} 
Assim, Edivaldo M Boaventura ${ }^{183}$ entende que as relações entre a educação e o direito podem ser vistas pelo menos em três direções:

a) educação como prerrogativa concedida ao aluno para o desenvolvimento de suas potencialidades; a educação como direito público subjetivo transforma-se em educação como direito-norma.

b) educação como norma, que estabelece comportamentos, e é nesse sentido que a educação vem sendo regulamentada por um complexo de normas, que prevêem a estrutura, o funcionamento dos serviços educacionais e definem os direitos e deveres de alunos, professores e escolas.

c) educação vista como direito educacional, englobando tanto a educação como direito subjetivo dos alunos, como legislação do ensino, que envolve a normatização de toda a estrutura educacional.

No Direito brasileiro, há uma corrente que acredita na existência de um novo ramo específico e especial do direito denominado Direito Educacional ${ }^{184}$, conforme esta terceira direção da relação entre o direito e a educação no olhar de Boaventura. Não cabe, porém, a este trabalho, analisar o conteúdo e o contexto deste posicionamento, sendo que para o presente momento, é a primeira direção de Boaventura que interessa à análise, ou seja, a visualização da educação como direito subjetivo.

A educação é, portanto, um direito humano, decorrente da simples existência do ser humano, que têm início com o seu nascimento e apenas termina com a sua morte. Como afirma César P. da S. Machado Jr.:

Esse direito não se refere tão somente a uma liberdade de aprendizagem (liberdade de pensamento, de expressão e de acesso à informação), mas se caracteriza como direito social, pois todos podem exigir do estado a criação de serviços públicos para atendê-lo, tendo características de direito absoluto, intransmissível, irrenunciável e inextinguível.

Assim, a educação, no aspecto jurídico que importa ao presente estudo, é entendida como um direito fundamental do ser humano, correspondendo, portanto a um dever do Estado, da comunidade internacional e dos indivíduos, bem como a um direito de todos os seres humanos. Carrega consigo, portanto, todas as características especiais dos direitos humanos, fundamentais para a realização de uma vida digna.

crescimento, uma vez que a educação é que dá ao ser humano a possibilidade de poder-ser; (ii) psicológico, porque o indivíduo é o que fez dele mesmo, mas antes, é o que a educação faz de si, o ser humano inicia-se esculpido pela sua educação; (iii) moral, porque é a educação que dá ao indivíduo o seu sentido de moralidade; (iv) econômico, vez que a educação cada vez mais é considerada como um dos melhores investimentos; (v) político, no sentido aristotélico, já que só a educação permite que o indivíduo entre e participe da polis; e (vi) jurídico, pois reconhecido como direito humano, capacitador do indivíduo. (2003, p.764-765).

${ }_{183}^{184}$ Apud Machado Jr., 2003, p. 18.

${ }^{184}$ Sobre o direito educacional no direito brasileiro, ver a obra pioneira de Renato Alberto Teodoro Di Dio, intitulada "Contribuição à sistematização do direito educacional”, 1981. 
No entanto, o reconhecimento da educação como direito humano também passou por um processo de polêmica e debate, no quadro da aceitação dos direito econômicos, sociais e culturais como direitos humanos tão importantes quanto os direitos civis e políticos.

Isso porque a educação é entendida como um direito social, deste grupo, chamado didaticamente de direitos de segunda geração, cuja implementação deve ocorrer simultaneamente e de forma complementar a dos direitos de primeira geração (civis e políticos), em atenção aos princípios da universalidade, interdependência e unicidade dos direitos humanos.

Assim, para entender o atual status da educação como direito humano, convém apresentar um breve histórico sobre o seu reconhecimento no âmbito do processo de aceitação dos direitos sociais, econômicos e culturais como direitos humanos universais e atemporais.

\subsubsection{O reconhecimento internacional do direito à educação}

Os chamados direitos de segunda geração surgem, conforme mencionado no primeiro capítulo, da constatação de que o reconhecimento da liberdade e da igualdade formal não é suficiente para o exercício dos direitos humanos por todos os indivíduos.

Assim, a quebra do regime absolutista e o surgimento das sociedades liberais contribuíram para a afirmação de que o indivíduo deve ser livre para exercer suas capacidades, sem que o Estado possa interferir na realização de seus objetivos, com exceção daquilo que está previsto na lei. O Estado, portanto, deve reconhecer que os seres humanos possuem direito sobre suas liberdades e que todos são iguais.

Ocorre que rapidamente notou-se que essa suposta igualdade tornava-se inútil a determinadas camadas da sociedade, já que outros atores, que não os Estados, passaram a restringir as liberdades de alguns indivíduos pelo exercício de um poder de hierarquia, sendo que os empregadores exerciam um poder quase monarca absoluto sobre os trabalhadores, tratados com igualdade pela lei.

Essa situação só poderia resultar, como ressalta o Professor Fábio Konder Comparato ${ }^{185}$, na "brutal pauperização das massas proletárias", o que provocou a organização da classe trabalhadora, a fim de reivindicar a igualdade efetiva. Essa organização e a constante reivindicação por melhores condições permitiram a afirmação de algumas exigências

${ }^{185}$ Comparato, 2008, p. 54. 
sociais e econômicas como direitos humanos, o que veio a ocorrer no plano internacional, no início do século XX, com a Constituição de Weimar, de 1919.

Assim, reconhece-se que o exercício efetivo das liberdades fundamentais, aclamadas desde a Revolução Francesa, por todos os seres humanos somente poderia ocorrer a partir do estabelecimento de condições especiais que buscariam a eliminação das desigualdades sociais e econômicas entre os indivíduos.

Conforme apresentado anteriormente, no plano internacional, o reconhecimento dos direitos econômicos, sociais e culturais como direitos humanos universais ganha força a partir da constatação de que a situação econômica social e política de um país possui reflexos no plano internacional e que a sua participação nas relações internacionais influencia sua capacidade de desenvolver-se e de garantir a proteção dos direitos humanos internamente.

Assim, notou-se que os direitos econômicos, sociais e culturais somente poderiam ser efetivamente garantidos dentro de uma ordem econômica internacional que possibilitasse o desenvolvimento de todos os Estados e indivíduos. Isso porque, como lembra Flávia Piovesan ${ }^{186}$, ao contrário dos direitos civis e políticos, que são auto-aplicáveis, os direitos econômicos, sociais e culturais são programáticos, demandando a intervenção dos Estados. Assim, dependem de um mínimo de recursos econômicos disponível, um padrão mínimo técnico-econômico, um mínimo de cooperação econômica internacional e prioridade na agenda política internacional. Percebeu-se, portanto, que reconhecer determinados direitos como direitos humanos somente faria sentido dentro de um sistema de cooperação e responsabilidade internacional.

Essa percepção não foi aceita facilmente por todos os Estados, vez que dentro desta lógica, os interesses dos países menos favorecidos têm prioridade, desde que voltados a melhorar a situação dos seus nacionais que se encontram em situação limite, na qual não podem exercer efetivamente seus direitos e liberdade fundamentais.

Assim, como demonstrado no capítulo anterior durante o estudo do processo de reconhecimento do direito ao desenvolvimento como direito humano, a idéia de um direito internacional de cooperação vem ganhando espaço aos poucos, enfrentando a relutância dos países desenvolvidos e as suas exigências por contra-prestações. Mesmo assim, a

${ }^{186}$ Piovesan, 1997, p. 195. 
lógica da cooperação internacional econômica e social, prevista já na Carta da ONU e na Declaração Universal dos Direitos do Homem, é aceita atualmente como válida no discurso e na prática da defesa dos direitos humanos, em especial para os direitos econômicos, sociais e culturais, que mais dependem desta cooperação.

Pode-se dizer, portanto, que o direito à educação, dentro do rol de direitos econômicos, sociais e culturais, foi proclamado como um direito humano universal no plano internacional somente após a Segunda Guerra Mundial $^{187}$, com a criação da ONU e de sua agência especializada, a UNESCO ${ }^{188}$.

É bem verdade, porém, que a preocupação dos Estados com a garantia do acesso à educação não é tão recente quanto sua positivação e aceitação como direito humano no plano internacional. Assim, a educação sempre foi vista como importante fator para o desenvolvimento humano, sendo que obrigação dos pais prover a educação das crianças a fim de torná-los capazes de aproveitar devidamente e de forma completa suas liberdades e possibilidades.

Assim, as tendências e teorias jusnaturalistas já apontavam para a concepção de que a educação é um dos direitos que decorrem tão-somente da vida do homem, independentemente de seu reconhecimento ou não por normas jurídicas.

As Revoluções Francesa e Americana também já determinavam a promoção da educação (ao menos para a maioria dos cidadãos) como uma função pública do Estado, afirmando que a educação pública era necessária para alcançar os ideais de igualdade dessas revoluções, não devendo ser exclusiva de uma classe social em particular $^{189}$.

\footnotetext{
${ }^{187}$ Conforme já mencionado anteriormente, os acontecimentos da Segunda Guerra colocaram os direitos humanos no centro das preocupações internacionais, levando à criação das Nações Unidas, como organização internacional voltada para a manutenção da paz e da segurança internacionais, por meio da proteção, promoção e garantia dos direitos humanos.

${ }^{188}$ A Organização das Nações Unidas para a Educação, Ciência e Cultura (UNESCO, sigla em inglês) foi criada como agência especializada da ONU, de acordo com o artigo 57, da Carta das Nações Unidas. Assim, apesar de estar sujeita à autoridade da ONU, goza de relativa autonomia, pois constitui uma organização internacional com personalidade jurídica própria, criada por acordo inter-governamental. A Carta de Constituição da UNESCO foi assinada em 1945 e entrou em vigor em 1946. Atualmente, possui 193 Estados Membros e 6 membros associados. Dados disponíveis em: <http://www.brasilia.unesco.org/unesco >. Acesso em: 05 jan. 2009.

${ }^{189}$ Hodgson, 1996, p. 239.
} 
Posteriormente, outras nações incorporaram a educação primária universal e gratuita com parte dos seus objetivos em suas constituições nacionais ${ }^{190}$, antes ainda que o direito à educação fosse declarado internacionalmente.

Não há dúvidas, porém, que a partir de 1945, a ONU e a UNESCO passaram a encabeçar os debates sobre a importância do reconhecimento da educação como direito humano social a ser positivado nos planos internacional e interno. Assim, a Carta das Nações Unidas já indica a necessidade de cooperação para solucionar os problemas de caráter educacional. E, em atenção às determinações da Carta, a Constituição da UNESCO também aponta a necessidade da educação para a promoção da paz ${ }^{191}$.

Desde então, a educação vem sendo reconhecida especificamente como direito humano por diversos instrumentos internacionais. A Declaração Universal dos Direitos do Homem, de 1948, foi a primeira a reconhecer direta e especificamente um direito geral à educação, atestando, em seu artigo 26, parágrafo $1^{\circ}$, que: "Toda pessoa tem direito à educação. A educação será gratuita, pelo menos nos graus elementares e fundamentais. A educação elementar será obrigatória. A instrução técnico-profissional será acessível a todos, bem como a educação superior, esta baseada no mérito".

Posteriormente, as disposições sobre o direito à educação da Declaração Universal foram reafirmadas por outros instrumentos internacionais da própria $\mathrm{ONU}$, que tratam de temas ou grupos específicos.

No âmbito da UNESCO, em 14 de dezembro de 1960, foi adotada a Convenção contra a Discriminação na Educação, que afirma novamente o direito à educação como direito humano e aponta os primeiros padrões internacionais da educação pública, cuja base é a erradicação da discriminação, de modo que esse direito possa ser exercido por todos os indivíduos.

Em 1966, a adoção do Pacto Internacional sobre os Direitos Econômicos, Sociais e Culturais expande o conteúdo do direito à educação previsto na Declaração Universal, sendo que seu artigo 13 consiste até hoje o maior e mais detalhado dispositivo jurídico

\footnotetext{
${ }^{190}$ Neste sentido, a Constituição Federal brasileira de 1824 já previa que a instrução primária deveria ser gratuita a todos (artigo 179, inciso XXXII). Ainda que, concretamente, essa educação gratuita nunca tenha existido durante o império, sua simples referência no texto constitucional já demonstra a que a preocupação com a educação é antiga e bastante difundida.

${ }^{191}$ Artigo 55, "b", da Carta das Nações Unidas e Artigo $1^{\circ}$ (1), da Constituição da UNESCO.
} 
internacional sobre o direito à educação, atestando-o como um direito humano de natureza social.

Além destes, vários outros instrumentos internacionais continuaram a reforçar a importância da proteção e garantia do direito à educação como direito humano universal, tais como a Convenção sobre os Direitos das Crianças (artigo 29, parágrafo $1^{\circ}$ ), de 1989; a Declaração Mundial sobre Educação para Todos (Declaração de Jomtien), de 1990; a Convenção de Viena (Parte I, parágrafo 33 e Parte II, parágrafo 80), de 1993, entre outros $^{192}$.

\subsubsection{Direito à educação e desenvolvimento ${ }^{193}$}

O artigo 26, da Declaração Universal dos Direitos do Homem, consagra a principal finalidade do direito à educação como sendo possibilitar o pleno desenvolvimento da personalidade humana, um fim que resume todos os outros. Isso significa dizer que o direito à educação é o direito a todo aprendizado necessário e indispensável ao desenvolvimento de todas as dimensões da personalidade humana.

A educação é, portanto, um direito de todos para obter-se o pleno desenvolvimento da pessoa, para que a vida seja com qualidade e aptidão para o exercício da cidadania ${ }^{194}$.

Assim como o direito ao desenvolvimento, o direito à educação, além de ser um direito humano per se, também é indispensável para a realização de diversos outros direitos humanos, em especial as liberdades civis e políticas do indivíduo.

Dessa forma, pode-se dizer que o direito à educação é um direito de "empoderamento"195, que se caracteriza como o principal veículo pelo qual indivíduos marginalizados

\footnotetext{
${ }^{192}$ Além dos instrumentos jurídicos em âmbito global, o direito à educação também está previsto em diversos documentos regionais, como a Carta Africana sobre Direitos Humanos e dos Povos (Artigo 17, parágrafo 1), de 1981; a Convenção Européia pela Proteção dos Direitos Humanos e Liberdades Fundamentais, de 1950; e a Carta da Organização dos Estados Americanos (artigos 47 e 48), de 1948, seguida da Declaração Americana de Direitos e Deveres do Homem (artigo 12).

193 Ainda neste capítulo, no item que se refere especificamente à educação superior, tratar-se-á com maior profundidade da importância da deste setor educacional para o desenvolvimento, sendo que neste momento, cabem apenas algumas considerações gerais acerca desta relação, que já fora inicialmente apresentada no final do capítulo anterior.

${ }^{194}$ Machado Jr., 2003, p. 15. Daí, portanto, a importância do direito à educação como parte dos direitos humanos protegidos pelo direito humano ao desenvolvimento.

$195 \mathrm{O}$ reconhecimento do direito à educação como um direito de "empoderamento" (empowerment right) concede-lhe a característica de um direito que garante ao individuo o controle sobre o curso de sua própria vida. É um direito que capacita o ser humano a experimentar todos os benefícios dos outros direitos. Assim, os direitos civis e políticos, tais como a liberdade de expressão e de associação ou de participação política somente ganham substância e significado quando o indivíduo é instruído. (Coomans, 1995, p. 1).
} 
econômica e socialmente podem participar de forma completa nas suas comunidades. Assim, a educação permite que as mulheres alcancem maior espaço na sociedade e que as crianças não estejam sujeitas a trabalhos abusivos e exploradas sexualmente, além de contribuir para a promoção dos direitos humanos e da democracia, da proteção do meio ambiente e do controle do crescimento populacional ${ }^{196}$.

Como bem salientou Renato Alberto Teodoro Di Dio ${ }^{197}$ :

(...) quando se preserva a vida, procura-se protegê-la para que seja uma vida digna, plena, produtiva e feliz. Se assim é, a educação apresenta-se como condição dessa dignidade, plenitude, produtividade e felicidade. Preservarse a vida sem que, ao mesmo tempo, se criem condições para que o indivíduo desenvolva e atualiza as suas potencialidades, mais do que um absurdo lógico, é uma claudicação moral. Manter-se o individuo vivo sem que se lhe garantam as possibilidades de realizar seus anseios naturais é assegurar uma expectativa de antemão frustrada. Mesmo porque o direito à vida não se cinge à preservação biológica, mas se estende aos valores psicológicos, sociais, político e morais, que, sem um mínimo de educação, não chegarão a existir para o ser humano.

Por estes motivos, entre outros muitos, a educação só pode ser vista como um ótimo investimento do Estado - o melhor, em verdade - já que cidadãos instruídos, com a mente ativa, capazes de pensar por si próprios e exercer seus direitos, só podem contribuir para o desenvolvimento geral de um país, já que constituem uma força de trabalho e um eleitorado qualificado ${ }^{198}$.

A educação ainda aumenta as chances de mobilidade social, podendo ajudar o indivíduo a escapar da discriminação baseada nos status social. Também promove a realização de outros direitos econômicos e sociais, como o direito ao trabalho, o direito à alimentação e o direito à saúde, já que um ser humano instruído terá maiores chances de conseguir um emprego, estará melhor equipado para assegurar seu próprio fornecimento de alimentos e estará mais consciente dos perigos de saúde pública ${ }^{199}$.

Importante ressaltar que o estudo do direito à educação torna-se ainda mais importante em vista da evolução da sociedade, já que a complexidade do mundo atual exige mais e maiores esforços para uma educação mais compatível com as suas necessidades. Além

\footnotetext{
${ }^{196}$ Observação Geral no 13 do Comitê sobre Direitos Econômicos, Sociais e Culturais (E/C.12/1999/10, parágrafo 1).

${ }^{197}$ Di Dio, 1981, p. 88.

198 Tomasevski, 2005, p. 715.

${ }^{199}$ Coomans, 1995, p. 2.
} 
disso, é fato que o exercício pleno da cidadania é condição essencial para que o processo de civilização seja usufruído e compartilhado por todos ${ }^{200}$.

Konrad Hesse, em seus estudos sobre direito constitucional, reforça a relação existente entre educação e democracia ao afirmar que esta depende de cidadãos emancipados, informados e não de uma massa de ignorantes, apática e que se deixa dirigir por emoções. Ou seja, democracia e educação guardam uma forte relação, pois o legítimo poder democrático depende de uma participação ativa dos cidadãos. ${ }^{201}$

Koichiro Matsuura, Diretor-Geral da UNESCO, ressalta que, na verdade, a educação, em qualquer nível, deixou de ser apenas um direito fundamental consagrado na Declaração Universal dos Direitos dos Homens a que todo ser humano pode aspirar, legitimamente, para a sua realização pessoal. Ela passou a ser precondição essencial para qualquer tipo de desenvolvimento, para a redução da taxa de desemprego e da pobreza, para o progresso social e cultural, para a promoção de valores democráticos e para o estabelecimento de uma paz duradoura. ${ }^{202}$

No âmbito da OMC, também se reconhece, sem margens para dúvidas, que a educação desempenha um papel crucial para favorecer o crescimento econômico e o desenvolvimento pessoal e social e para reduzir as desigualdades ${ }^{203}$.

Dessa forma, evidente que a educação não apenas traz impactos para o ser humano na sua individualidade, mas também pode aprimorar a qualidade de vida do indivíduo em coletividades. Assim, se por um lado, a educação pode facilitar o aumento da consciência dos indivíduos, além de contribuir para o desenvolvimento pessoal de formação da integridade e identidade do ser humano, por outro, pode também ser um meio de melhorar a sua vida na esfera coletiva, já que pode assegurar bons empregos, bons salários, status social, mobilidade social e desenvolvimento nacional. A educação transmite conhecimento e habilidades que serão utilizados na vida em família e em comunidade. ${ }^{204}$

\footnotetext{
${ }^{200}$ Machado Jr., 2003, p. 15.

${ }^{201}$ Hesse, 1998, p. 133.

202 Discurso proferido por ocasião da sessão interativa temática sobre educação para todos nos países de menor desenvolvimento relativo, ocorrida em Bruxelas, em 16 de maio de 2001. Disponível em: $<$ http://unesdoc.unesco.org/images/0012/001225/122570e.pdf\#xml=http://unesdoc.unesco.org/ulis/cgibin/ulis.pl?database $=$ dgsp\&set=3C42944F_3_35\&hits_rec=7\&hits_lng=eng $>$.

${ }^{203}$ Background Note do Secretariado da OMC sobre serviços educacionais, 1998, parágrafo 6 (S/C/W/49).

${ }^{204}$ Halvorsen, 1991, p. 343.
} 
Ressalte-se, ainda, que a educação tem papel fundamental na medição do Índice De Desenvolvimento Humano (IDH) de uma nação, que leva em consideração o grau de analfabetismo e o número de matrículas em todos os níveis da educação, além dos números do Produto Interno Bruto e (PIB) e de longevidade (expectativa de vida ao nascer).

Assim, muitos relacionam a ausência da educação como uma das grandes e principais causas do atraso e do subdesenvolvimento de um país, ainda que pouco se possa afirmar concretamente sobre uma relação direta entre a falta de escolarização e a ausência ou retrocesso no desenvolvimento ${ }^{205}$.

Ainda que não evidenciada concreta e empiricamente, essa relação entre educação e desenvolvimento não deixa de refletir uma preocupação genuína com o problema do acesso e da qualidade de ensino nos países em desenvolvimento e de menor desenvolvimento relativo. Afinal, é curioso que exatamente nesses países é que se encontram os menores índices de escolaridade do mundo. A dúvida que permanece (e que permeia todas as possíveis conseqüências e causas do desenvolvimento) é se é o desfalque na educação que contribui para o subdesenvolvimento ou o inverso.

Dessa forma, não se pode de todo descartar a idéia de que:

A ignorância, se instalada endemicamente, assume proporções de verdadeira calamidade pública. É ela que reduz nosso homem a meio homem, a um quarto de homem, e a nossa população à metade ou quarto da realidade; ela e só ela, é a responsável pelo relativo atraso de nossa Pátria, que não pode sofrer o confronto com as outras ${ }^{206}$.

Percebe-se, diante do exposto, que o objetivo último do direito à educação é o desenvolvimento em sentido amplo, que capacita e faz crescer o ser humano, para torná-lo sujeito efetivo dos direitos humanos que pode - e deve - ter um papel ativo na sociedade.

Reafirmada a premissa de que o direito à educação é fundamental para o desenvolvimento como direito humano, mister se faz avaliar o seu conteúdo jurídico, com base nos dispositivos internacionais que prevêem a educação como um direito humano universal.

\subsection{O CONTEÚDO DO DIREITO À EDUCAÇÃO}

Segundo Agostinho dos Reis Monteiro, o conteúdo jurídico de um direito é determinado pela identificação da sua titularidade, objeto e oponibilidade, importando saber de que

\footnotetext{
${ }^{205}$ Ribeiro, 2005, p. 325.

206 Paiva, 1987.
} 
meios de proteção esse direito dispõe. Assim, analisar o conteúdo jurídico do direito à educação significa identificar quais os seus sujeitos ativos (a quem se destina o direito) e passivos (por quem é devido o direito) e como pode ser reclamado em caso de violação ${ }^{207}$.

Conforme já mencionado acima, as normas relativas ao direito à educação estão dispersas por diversos instrumentos jurídicos internacionais e regionais, de natureza convencional ou declaratória, com efeito vinculante e não vinculante, de conteúdo geral, específico e categorial.

Pode-se dizer, porém, que as principais disposições referentes a este direito são: (i) o artigo 26, da Declaração Universal dos Direitos do Homem; (ii) os artigos 13 e 14, do Pacto Internacional sobre os Direitos Econômicos, Sociais e Culturais; e (iii) artigos 28 e 29, da Convenção sobre os Direitos da Criança ${ }^{208}$.

Ressalte-se que as provisões da Declaração Mundial sobre Educação para Todos ${ }^{209}$ reafirmam as determinações previstas nos instrumentos principais, buscando complementálas e esclarecê-las, abordando os conceitos apresentados por estes instrumentos de forma mais profunda.

Os artigos do Pacto Internacional de 1996, porém, conforme já mencionado, é que são considerados os mais abrangentes e completos no que tange à proteção e à promoção do direito à educação. Além disso, este instrumento jurídico internacional é um acordo internacional, possuindo, portanto, força vinculante sobre seus Estados parte. Assim, são esses dispositivos que servirão de base principal para a análise do conteúdo jurídico deste direito a que se dá seguimento nos itens seguintes do presente trabalho.

\subsubsection{O objeto do direito à educação}

Conforme visto anteriormente, das disposições internacionais sobre o direito à educação, é possível afirmar que trata-se de um direito humano de todo ser humano, cuja finalidade máxima é possibilitar o pleno desenvolvimento da personalidade humana, em todas as suas dimensões.

\footnotetext{
${ }^{207}$ Monteiro, 2003, p. 767.

${ }^{208}$ Monteiro, 2003, p. 767-768.

${ }^{209}$ A Declaração Mundial sobre Educação para Todos foi adotada por ocasião da Conferencia Mundial sobre Educação para Todos, realizada em Jomtien, Tailândia, entre os dias 5 e 9 de março de 1990.
} 
Pode-se dizer, portanto, que o objeto das normas internacionais, que afirmam o direito à educação como direito humano é dar as bases e os padrões mínimos para que este direito humano alcance seu objetivo principal. Assim, o conteúdo dos instrumentos jurídicos sobre o direito à educação, além de determinar seus sujeitos passivo e ativo, volta-se a elencar quais as premissas básicas, que deverão ser observadas por todos, para que o direito à educação, de fato, permita o desenvolvimento da personalidade humana.

Neste sentido, o artigo 13 do Pacto Internacional sobre os Direitos Econômicos, Sociais e Culturais, prevê algumas determinações fundamentais sobre a educação: i) a educação primária é compulsória e deve estar disponível gratuitamente a todos; ii) a educação secundária deverá ser generalizada, a fim de que todos possam obtê-la e deverá tornar-se acessível a todos, por meio da implementação progressiva do ensino gratuito; iii) a educação em nível superior também deverá tornar-se acessível a todos, com base na capacidade de cada um e por meio da implementação progressiva do ensino gratuito; iv) deve-se fomentar e intensificar a oferta da educação de base para todos aqueles que não receberam educação primária ou não a concluíra; e v) é necessário sempre aprimorar a rede escolar em todos os níveis de ensino.

Percebe-se, portanto, que a busca pelo direito à educação com vistas ao desenvolvimento pleno da personalidade humana só pode ser alcançando quando atendidas as determinações elencadas acima, com especial atenção para o fato de que o direito à educação não engloba apenas a educação primária, mas carrega objetivos e obrigações quanto aos demais níveis.

A Declaração Mundial sobre Educação para Todos complementa as disposições do Pacto Internacional sobre a educação primária e reforça que a esta deve ser universal, devendo garantir que as necessidades básicas de aprendizagem de todas as crianças sejam satisfeitas, assim como deve levar em consideração a cultura, as necessidades e as oportunidades da comunidade (artigo $5^{\circ}$, da Declaração).

Juntamente com a educação secundária, a educação infantil constitui a chamada educação básica, sendo considerada a sua parte mais importante $e^{210}$.

${ }^{210}$ Comentário Geral $n^{\circ} 13$, do Comitê de Direitos Econômicos, Sociais e Culturais, 1999, parágrafo 9 (E/C.12/1999/10). 
A educação secundária é muito importante para o desenvolvimento humano, pois compõe a educação básica, complementando a educação primária, de forma a preparar os estudantes para as oportunidades da educação vocacional e superior.

Neste nível, o artigo 13 do Pacto Internacional reconhece implicitamente que seu conteúdo é variável e flexível, dependendo da legislação interna que regulamenta o setor em determinado país. Assim, entende que essa flexibilidade é fundamental para que sejam atendidas as necessidades dos estudantes e das comunidades em situações sociais e culturais diversas.

Essas considerações também se aplicam à educação em nível superior ${ }^{211}$, que também deve atender as necessidades de estudantes em condições sociais e culturais diversas. A particularidade deste setor educacional é o fato de que deverá ser igualmente acessível a todos, mas com base na capacidade pessoal de cada indivíduo.

Por fim, cumpre ressaltar apenas que na educação secundária e superior, ao contrário da educação primária, o ensino gratuito não é visto como uma obrigatoriedade imediata, sendo que o seu oferecimento aos indivíduos de forma gratuita deve ocorrer progressivamente ${ }^{212}$.

\subsubsection{O sujeito ativo do direito à educação}

O direito à educação, conforme previsão do artigo 13 do Pacto Internacional sobre Direitos Econômicos, Sociais e Culturais, é um direito universal, ou seja, garantido a todas as pessoas, independentemente de idade, língua, origem étnica ou social ou qualquer outro status.

Ao contrário do que alguns podem pensar, o direito à educação não é um direito exclusivo das crianças, mas

é um direito de "toda pessoa", sem discriminação alguma e sem limites de tempo ou espaços exclusivos para o seu exercício. É direito da criança e do adulto, da mulher e do homem, seja qual for a sua capacidade física e mental, a sua condição e situação. É direito dos brancos, dos pretos, dos mestiços e dos amarelos, dos pobres e dos ricos, dos emigrantes, dos

${ }^{211}$ Comentário Geral no ${ }^{13}$, do Comitê de Direitos Econômicos, Sociais e Culturais, 1999, parágrafo 18 (E/C.12/1999/10).

${ }^{212}$ Ainda neste capítulo, serão estudados os princípios norteadores do direito à educação, entre os quais será tratado o tema da progressividade do ensino gratuito. 
refugiados, dos presos etc. é direito das populações indígenas e de todas as minorias. $^{213}$

No entanto, como bem denota Agostinho dos Reis Monteiro ${ }^{214}$, podem-se ressaltar algumas prioridades:

A prioridade da criança, que é o ser-educando por excelência, dada a intensidade da sua educabilidade e a ressonância pessoal e social da educação da infância, principalmente da primeira infância.

A prioridade das meninas, pelas discriminações de que continuam a ser vítimas e pela repercussão que a educação das mães tem nos filhos e na sociedade em geral.

A prioridade das pessoas iletradas, diminuídas na sua capacidade de "ser gente" (...).

De qualquer maneira, os sujeitos ativos do direito à educação são os indivíduos, como principais titulares dos direitos humanos. A ética do direito à educação é uma ética do interesse superior do educando, que não pode ser tratado e instrumentalizado como objeto da educação, mas deve ser considerado e respeitado sempre como sujeito do seu direito à educação. $\mathrm{O}$ direito à educação não é um direito dos pais sobre os filhos, nem do Estado sobre os cidadãos, mas sim um direito dos filhos e dos cidadãos às responsabilidades dos pais e do Estado para com o seu direito à educação.

Cabe ressaltar que o direito à educação, como o direito ao desenvolvimento, também carrega uma dimensão coletiva, de modo que pode ser entendido como o direito de coletividades a garantir aos seus membros o acesso a uma educação de qualidade.

Neste sentido, Kate Halvoresen ${ }^{215}$ reforça a idéia de que é um erro afirmar que os direitos humanos são direitos apenas de indivíduos, pois essa concepção contradiz a ação coletiva e social. Isso porque os direitos humanos são direitos de indivíduos, mas o indivíduo é um indivíduo social inserido em diversas coletividades. Além disso, como esses direitos se destinam a todos os indivíduos, sua implementação implica na realização de ações coletivas e sociais. Os seres humanos agem, portanto, tanto como indivíduos como coletividades, de forma moral e instrumental, sendo que direitos individuais implicam o reconhecimento de direitos coletivos e vice versa.

\subsubsection{Os sujeitos passivos: deveres decorrentes do direito humano à educação}

\footnotetext{
${ }^{213}$ Monteiro, 2003, p. 769.

${ }^{214}$ Monteiro, 2003, p. 769.

${ }^{215}$ Halvorsen, 1990, p. 347.
} 
Os instrumentos internacionais sobre o direito à educação não trazem apenas dispositivos sobre os seus beneficiários e titulares, mas prescrevem também obrigações a alguns sujeitos detentores dos deveres e obrigações relacionadas à proteção e à promoção do direito à educação como direito humano.

Assim, quando os Estados parte de um acordo internacional reconhecem a necessidade de garantir a realização do direito à educação, comprometem-se automaticamente a fazê-lo nos seus respectivos territórios, o que os caracteriza desde logo como agentes com obrigações e responsabilidades quanto a esse direito.

Mas o direito à educação não obriga apenas os Estados, tratando também os pais e a comunidade internacional como responsáveis pela efetividade deste direito. Os pais são naturalmente os primeiros responsáveis pelo direito à educação dos filhos, mas o Estado é o principal responsável pela satisfação do direito à educação ${ }^{216}$.

Isso porque, apesar do dever da família de buscar a educação de seus filhos, é fato que muitas, sobretudo as mais pobres, não possuem os recursos necessários para criar todas as possibilidades de satisfação do direito à educação, sendo que cabe ao Estado garantir o acesso à educação gratuita de qualidade a todos os seus indivíduos.

Pode-se dizer que o dever dos pais também se refere à defesa do direito à educação dos seus filhos perante o próprio Estado, devendo exigir deste a prestação dos serviços educacionais da forma como comprometeu-se a oferecer.

O Estado é que tem a capacidade e a prerrogativa de formular as normas e adotar medidas necessárias para satisfazer o direito à educação e é o Estado que assume os compromissos de fazê-lo na esfera internacional e também nacional, a partir da inclusão das determinações sobre o direito à educação como direito humano nos ordenamentos nacionais.

Da mesma forma que o direito ao desenvolvimento enseja responsabilidades à comunidade internacional, esta também possui um papel importante para o direito à educação como responsável pela sua realização. Assim, cabe mencionar mais uma vez os artigos 22 e 28, da Declaração Universal dos Direitos do Homem, que reforçam a importância da cooperação internacional para a promoção e proteção dos direitos humanos, em especial dos direitos econômicos, sociais e culturais, grupo do qual faz parte o direito à educação. 
Vê-se, portanto, novamente que o direito ao desenvolvimento deve ser encarado como uma obrigação de todos os Estados, dentro da idéia de cooperação e solidariedade internacional e de relações internacionais econômicas justas, a fim de que o direito à educação, como parte do processo de desenvolvimento humano, seja assegurado e satisfeito a todos os indivíduos.

Neste sentido, a Declaração de Jomtien ${ }^{217}$ também ressalta a importância da responsabilidade da comunidade internacional: "Satisfazer as necessidades educativas fundamentais constitui uma responsabilidade comum e universal da humanidade, que exige a solidariedade internacional e relações econômicas equitativas e justas, a fim de corrigir as disparidades econômicas existentes".

Por fim, cumpre destacar o dever dos próprios indivíduos para com o seu direito à educação, como meio de garantir a sua dignidade e o aproveitamento pleno de suas capacidades $^{218}$.

\subsection{OS PRINCÍPIOS INTERNACIONAIS DO DIREITO À EDUCAÇÃO}

O direito à educação, na forma como é previsto pelos instrumentos internacionais já mencionados anteriormente, rege-se especialmente por alguns princípios, que deverão ser sempre observados para a sua efetiva realização.

Assim, da análise dos artigos 26, da Declaração Universal dos Direitos do Homem e 13, do Pacto Internacional sobre Direitos Econômicos, Sociais e Culturais, pode-se aferir a presença de três princípios base do direito à educação, quais sejam: (i) a universalidade; (ii) a gratuidade; e (iii) a progressividade.

Senão, vejamos:

Artigo 26

1. Toda a pessoa tem direito à educação. A educação deve ser gratuita, pelo menos a correspondente ao ensino elementar fundamental. O ensino elementar é obrigatório. O ensino técnico e profissional deve ser generalizado; o acesso aos estudos superiores deve estar aberto a todos em plena igualdade, em função do seu mérito.

\footnotetext{
${ }^{216}$ Monteiro, 2003, p. 770.

${ }^{217}$ Artigo $10^{\circ}$, parágrafo $1^{\circ}$, da Declaração Mundial sobre Educação para Todos.

${ }^{218}$ Como exemplo dessa obrigação, cite-se o artigo 31, da Declaração Americana de Direitos e Deveres do Homem, de 1948, que dispõe que: "Toda pessoa tem o dever de adquirir, pelo menos, a instrução primária".
} 
2. A educação deve visar á plena expansão da personalidade humana e ao reforço dos direitos do homem e das liberalidades fundamentais e deve favorecer a compreensão, a tolerância e a amizade entre todas as nações e todos os grupos raciais ou religiosos, bem como o desenvolvimento das atividades das Nações Unidas para a manutenção da paz.

3. aos pais pertence a prioridade do direito de escolher o gênero de educação a dar aos filhos.

Artigo 13

2. Os Estados-partes no presente Pacto reconhecem que, com o objetivo de assegurar o pleno exercício desse direito:

a) A educação primária deverá ser obrigatória e acessível gratuitamente a todos.

b) A educação secundária em suas diferentes formas, inclusive a educação secundária técnica e profissional, deverá ser generalizada e tornar-se acessível a todos, por todos os meios apropriados e, principalmente, pela implementação progressiva do ensino gratuito.

c) A educação de nível superior deverá igualmente tornar-se acessível a todos, com base na capacidade de cada um, por todos os meios apropriados e, principalmente, pela implementação progressiva do ensino gratuito.

Assim, pode-se aferir das expressões "toda pessoa tem direito à educação" e "a educação primária deverá ser obrigatória e acessível gratuitamente a todos", que o direito à educação carrega consigo o princípio da universalidade, que o dá a característica de direito humano. Como já foi visto anteriormente, o direito à educação é um direito de todos os indivíduos e , portanto, universal.

No que tange ao princípio da gratuidade, este é extraído da expressão "a educação deverá ser gratuita, pelo menos a correspondente ao ensino elementar fundamental". Assim, é possível afirmar que o ensino gratuito é um dos objetivos do direito à educação. Apesar de reconhecer que, nos níveis secundário e superior, esta gratuidade não é obrigatória, os dispositivos acima transcritos apontam para a importância de se buscar a gratuidade da educação em todos os seus níveis.

Não há como negar, portanto, que a gratuidade é um princípio constante no conteúdo do direito à educação, sendo que os responsáveis pela satisfação deste direito e todos aqueles que possuem qualquer responsabilidade com a sua realização deverão observar este princípio e esforçar-se para que o ensino gratuito torne-se cada vez mais acessível a todos os indivíduos que a desejarem e/ou não puderem arcar com os custos do ensino privado. 
Por fim, no eu diz respeito ao princípio da progressividade, deve-se ressaltar que trata-se de uma característica comum a todos os direitos econômicos, sociais e culturais. Isso porque, como foi visto, a realização plena desses direitos depende de diversos fatores, como a existência de recursos econômicos suficientes. Além disso, o conteúdo desses direitos é bastante dinâmico e sofre alterações para incluir novas exigências e novas preocupações relacionadas ao seu pleno cumprimento.

O conceito de progressividade, portanto, indica que a plena realização dos direitos econômicos, sociais e culturais, de modo geral, não poderá ser atingida em um curto período de tempo ${ }^{219}$, devendo, por este motivo, ser alcançada gradativamente, conforme as peculiaridades e capacidades de cada Estado.

Deve-se ressaltar, porém, que essa progressividade não deve ser interpretada como uma forma de esvaziar a obrigação de realizar plenamente o direito à educação, mas consiste apenas em uma forma de levar em conta a realidade do mundo concreto e as dificuldades envolvidas no que concerne a esta tarefa.

Ao contrário, a progressividade é a forma justa e possível que se encontrou para que se possa exigir de todos os responsáveis pelo direito à educação que o realizem de forma plena, ainda que em tempo mais longo. Assim, a progressividade impõe ao Estado o dever de tomar medidas concretas e específicas em direção às obrigações assumidas, em prazos previamente determinados no âmbito do Pacto Internacional sobre os Direitos Econômicos, Sociais e Culturais.

A progressividade, portanto, impede o retrocesso da política social do Estado que, tendo alcançado um certo nível de proteção do direito à educação, não pode retroceder e baixar o padrão de vida da comunidade, já que este direito está protegido pela cláusula de proibição do retrocesso social ${ }^{220}$.

Neste sentido, ensina Flávia Piovesan que:

(...) da obrigação da progressividade na implementação dos direitos econômicos, sociais e culturais decorre a chamada cláusula de proibição do retrocesso social, na medida em que é vedado aos Estados retrocederem no campo de implementação desses direitos. Vale dizer, a progressividade dos direitos econômicos, sociais e culturais proíbe o retrocesso ou a redução de políticas públicas voltadas à garantia desses direitos.

\footnotetext{
${ }^{219}$ Duarte, 2007, p. 699.
}

${ }^{220}$ Duarte, 2007, p. 700. 
Assim, uma vez previstos os princípios acima, seus efeitos intrínsecos ao direito à educação permitem afirmar que dos países signatários dos referidos instrumentos internacional sobre o direito à educação pode-se exigir total atenção a esses princípios, de forma que a prestação dos serviços educacionais nestes países deverá atendê-los.

\subsection{ELEMENTOS ESSENCIAIS DA PRESTAÇÃO DOS SERVIÇOS EDUCACIONAIS: OBRIGAÇÕES DECORRENTES DO DIREITO HUMANO À EDUCAÇÃO}

Pode-se considerar que o direito de receber uma educação, conforme as disposições do Pacto Internacional sobre os Direitos Econômicos, Sociais e Culturais, possui algumas características essenciais interdependentes, que devem ser observadas na prestação dos serviços educacionais.

Assim, a ex-relatora especial das Nações Unidas para o direito à educação, Katarina Tomasevski $^{221}$ desenvolveu quatro conceitos que devem nortear a prestação dos serviços educacionais a fim de que sejam expressões do direito humano à educação. São eles: (i) disponibilidade; (ii) acessibilidade; (iii) aceitação; (iv) adaptabilidade.

Importante esclarecer desde já que esses conceitos, tidos como exigências do direito à educação, não correspondem completamente ao conteúdo dos instrumentos internacionais que embasam esse direito, e, portanto, não são atendidos em sua plenitude pela maioria dos países. No entanto, indicam o caminho a ser seguido em busca da plena realização do direito à educação, devendo ser encarados como verdadeiras obrigações.

A disponibilidade pressupõe que a educação seja de fato oferecida a todos, devendo ser financiada pelo Estado, que também deverá garantir a infra-estrutura adequada e professores treinados capazes garantir o fornecimento da educação a todos. Assim, deve haver instituições de ensino e programas educacionais disponíveis o suficiente dentro de um Estado.

\footnotetext{
${ }^{221}$ Os conceitos desenvolvidos por Tomasevski foram apresentados ao longo de seus relatórios anuais enquanto relatora especial das Nações Unidas para o direito à educação, no período de 1998 a 2004 . Esses conceitos têm servido de base para grande parte dos estudos sobre a implementação do direito à educação e para o desenvolvimento de trabalhos acadêmicos sobre direitos humanos e educação e são conhecidos como os quatro A's (availability, accessibility, acceptability e adaptability). Os estudos dos relatores especiais para o direito à podem ser encontrados emãa $<$ http://www2.ohchr.org/english/issues/education/rapporteur/annual.htm>. Atualmente o relator especial da ONU para o direito à educação é Vernor Muñoz Villalobos.
} 
Evidente que esta obrigação refere-se especialmente ao fornecimento da educação primária, já que não há previsão expressa em instrumentos internacionais de que os demais níveis devam ser compulsórios e gratuitos. Mas não se deve esquecer que essas exigências devem ser incorporadas aos demais níveis da educação progressivamente. Portanto, podese dizer que, no que tange à disponibilidade dos níveis secundário e superior, os Estados têm obrigação de buscar cada vez mais meios de garanti-los a todos gratuitamente, de forma que a oferta desses serviços seja suficiente para atender a todos.

A preocupação com a acessibilidade (acesso) da educação refere-se à necessidade de que a o acesso à educação seja garantido a todos, sem discriminação. Pode-se dizer que esta obrigação possui três dimensões ${ }^{222}$. A primeira diz respeito ao princípio da nãodiscriminação, sendo que a educação deve ser fornecida a todos os indivíduos, independentemente de raça, cor, sexo ou situação econômica e social. Ao contrário, este elemento essencial ao direito à educação obriga os Estados a buscarem medidas positivas para a inclusão dos mais marginalizados, a fim de que estes também possam ter satisfeito seu direito humano à educação.

Uma segunda dimensão do acesso à educação refere-se ao aspecto físico da localização da instituição de ensino. Assim, o Estado deve garantir que todos os indivíduos possam ter acesso à educação ao seu alcance físico, de forma que possam buscá-la de maneira segura à sua saúde física.

Por fim, a terceira dimensão desta obrigação está relacionada à questão econômica. Isso significa que a educação deverá ser acessível economicamente a todos e tem intrínseca relação com o princípio da gratuidade, assim como a disponibilidade. Conforme já mencionado anteriormente, a gratuidade da educação primária é obrigatória para que se possa falar em uma educação acessível a todos. Quanto aos demais níveis, a gratuidade deve ser progressivamente inserida.

O conceito de aceitação, por sua vez, tem a ver com a forma e a substância da educação, incluindo a grade curricular e os métodos didáticos, que deverão ser aceitáveis pelos estudantes e pelos pais, no caso da educação primária. Assim, com base nas finalidades da educação - determinados pelo parágrafo $1^{\circ}$, do artigo 13 do Pacto Internacional sobre os

${ }^{222}$ Comentário Geral no 13 do Comitê de Direitos Econômicos, Sociais e Culturais da ONU, 1999, parágrafo 6(b) (E/CN.12/1999/10). 
Direitos Econômicos, Sociais e Culturais - o conteúdo do ensino deverá ser relevante, culturalmente apropriado e de boa qualidade ${ }^{223}$.

O Estado deverá, portanto, estabelecer um conteúdo educacional com padrões mínimos de qualidade pré-determinados para cada nível da educação, que deverão ser observados em todas as instituições de ensino. Caberá ao Estado supervisionar e fiscalizar para que todas atendam este mínimo exigido, sendo que a presença de instituições com conteúdo abaixo destes padrões será considerada violação ao direito à educação.

Por fim, a adaptabilidade da educação diz respeito à sua capacidade de ser flexível para adaptar-se às necessidades das sociedades e comunidades em constante mudança, correspondendo também às necessidades dos estudantes em seus diferentes níveis sociais e culturais.

Assim, o conteúdo da grade curricular, bem como a forma de organização do processo de aprendizagem deverão ser sempre revistos a fim de acompanhar a diversidade de culturas e as constantes mudanças sociais ${ }^{224}$.

Ressalte-se que essas exigências referentes ao oferecimento da educação são apresentadas no plano internacional primordialmente como obrigações do Estado. No entanto, cabe destacar que, ainda que o Estado possa delegar a prestação dos serviços educacionais a terceiros, ele permanece como responsável pela satisfação do direito à educação. Isso significa que, ainda que não seja o prestador direto da educação, deverá tomar as cautelas devidas para que os elementos essenciais à prestação da educação como direito humano sejam observados em qualquer situação.

\subsection{A EDUCAÇÃO COMO BEM PÚBLICO}

As comunidades humanas sempre tiveram necessidade de bens públicos, entendidos como recursos, bens e serviços que beneficiam cada indivíduo e todos os membros de uma comunidade, mas que ninguém pode ou quer produzir isoladamente.

A teoria econômica dos bens públicos tem origem nos anos 1950, definidos por oposição aos bens privados ${ }^{225}$. Naquele momento, os economistas ${ }^{226}$ definiram que os bens públicos

\footnotetext{
${ }^{223}$ Comentário Geral no 13 do Comitê de Direitos Econômicos, Sociais e Culturais da ONU, 1999, parágrafo 6(c) (E/CN.12/1999/10).

${ }^{224}$ Relatório preliminar da relatora especial para o direito à educação, Katarina Tomasevski, 13 de janeiro de 1999, parágrafo 70 (E/CN.4/1999/49).
} 
possuem duas características principais: (i) são não-excludentes (non-excludable); e (ii) não-rivais (non-rivalrous). Isso significa que não se pode excluir qualquer pessoa do consumo desses bens e que o seu consumo por alguns não impede, nem dificulta que outros o façam, ou seja, não diminui a possibilidade do consumo desses bens pelos demais.

Em outras palavras, os bens públicos enquanto não-rivais implicam que ninguém deve ser excluído da sua fruição, pois o custo marginal do aproveitamento dos seus benefícios por outros é zero. Por outro lado, o requisito da não-exclusividade para que um bem seja considerado público, afirma que ninguém pode ser excluído ${ }^{227}$.

Dessa forma, uma importante implicação dos bens públicos é que sua produção deve ser financiada pelo Estado de diversas formas, sem necessariamente depender de contraprestações dos usuários, como o pagamento de taxas. Por este motivo, os mecanismos de mercado individualmente não poderiam prover os bens públicos de forma eficiente e nem garantir níveis ótimos de produção, já que estes bens devem estar acessíveis a todos e não se sujeitam à concorrência. Os bens privados, por outro lado, não estão disponíveis a todos e estão sujeitos aos princípios e leis de mercado ${ }^{228}$.

Assim, os bens públicos são reconhecidos como aqueles cujos benefícios não podem ficar adstritos a um único "comprador" ou um grupo específico de "compradores". Além disso, a partir do momento em que um bem público é fornecido, ainda que consumido apenas por uma determinada pessoa, vários outros podem aproveitá-lo sem custo adicional.

Nesse sentido, a educação só pode ser entendida como um bem público, já que atende ambos os requisitos determinantes dos bens públicos. Isso porque, apesar de beneficiar o indivíduo que está sendo educado, não se pode evitar as externalidades que a educação deste indivíduo provocará nos demais e na sociedade. Assim, a sociedade como um todo se beneficiará com a possibilidade de participação de um indivíduo instruído no processo democrático ou mesmo em conseqüência de sua melhor formação como profissional. Essas externalidades é que diferenciam os bens públicos dos bens privados, que geram benefícios apenas para aquele que o consome ou apenas para um restrito grupo ${ }^{229}$.

\footnotetext{
${ }^{225}$ Monteiro, 2003, p. 776.

${ }^{226}$ Entre os exemplos de economistas que trataram da teoria dos bens públicos, ver: Samuelson, 1954 e Musgrave, 1959.

227 Stiglitz, 1999.

228 Tilak, 2005, p. 7.

${ }^{229}$ Kaul, Grunberg e Stern, 1999, sumário executivo.
} 
Considera-se que se as externalidades de um bem público estão limitadas a uma determinada região geográfica, ele será um bem público local ou regional, ao contrário dos bens públicos globais ou internacionais, cujos benefícios podem ser aproveitados por todo o mundo. São globais porque extravasam o quadro nacional, pela sua natureza ou pelas suas características técnicas ${ }^{230}$.

A noção de bens públicos globais ou internacionais ${ }^{231}$ é finalmente delimitada, fortalecendo-se como uma teoria relevante na comunidade internacional, com uma publicação do PNUD, em 1999, intitulada "Global public goods: international cooperation in the 21 st Century”.

O crescimento do debate sobre bens públicos globais se deve principalmente ao fato de que, com a globalização, as externalidades (tanto positivas quanto negativas, ou seja, tanto seus benefícios, quanto seus custos) desses bens alcançavam pessoas em outros países. Assim, questões que tradicionalmente eram tidas como exclusivamente nacionais, agora são temas globais, pois afetam toda a comunidade internacional.

Por este motivo, a aplicação do conceito de bens públicos globais é cabível aqueles bens cujos benefícios ultrapassam as fronteiras, as gerações e grupos de populações, como é o caso da educação.

Ocorre que, tanto na esfera nacional ou regional, quanto em âmbito global, os bens públicos tendem a sofrer de sub-fornecimento ${ }^{232}$, pois nem sempre conseguem produzir os benefícios a que se destinam, diante da pouca atenção que recebem. É o caso da educação, que, apesar do reconhecimento internacional como direito humano e bem público global, não apresenta melhorias significativas no plano interno dos Estados. E, no caso dos bens públicos internacionais, essa situação se agrava pelo fato de que as externalidades desses bens - que se referem tanto aos benefícios do seu amplo fornecimento, quanto aos custos

\footnotetext{
${ }^{230}$ Monteiro, 2003, p. 776.

${ }^{231}$ A aplicação do conceito de bens públicos ao âmbito internacional e aos desafios globais iniciou-se no final dos anos 1960, especialmente com as obras de Garrett Hardin (The tragedy of the commons, 1968), seguido de Bruce Russett e John Sullivan (Collective goods and international organization, 1971). Mais tarde, Charles Kindleberger (The world in depression 1929-1939, 1986) atribuiu a crise econômica dos anos 1930 ao fracasso no fornecimento de bens públicos chaves, como um sistema comercial aberto. Outras contribuições recentes foram Ruben Mendez (International public finance, 1992) e Todd Sandler (Global challenges: an approuch to environmental, political and economic problems, 1997). Assim, apesar de já existirem estudos sobre os bens públicos globais, até a publicação dos estudos do PNUD, pouco se falou sobre o que são de fato bens públicos e como se classificam (Kaul, Grunberg e Stern, 1999, sumário executivo).

${ }^{232}$ Kaul, Grunberg e Stern, 1999, sumário executivo.
} 
do seu sub-fornecimento - alcançam espaço cada vez maior no plano internacional, mas permanecem vinculadas à elaboração de políticas nacionais.

Dessa forma, os estudos do PNUD concluem que a melhor solução pata o fortalecimento dos bens públicos globais é o aprimoramento da cooperação internacional, já que isto aumentaria a capacidade dos governos nacionais para alcançar seus objetivos de políticas nacionais, vez que a cooperação internacional permite que os governos tenham algum controle sobre as forças transnacionais que afetam seu território e seus nacionais. Somente assim, pode-se alcançar os objetivos dos bens públicos internacionais, como a educação, a proteção do meio ambiente, a saúde pública, entre outros ${ }^{233}$.

\subsection{O ENSINO SUPERIOR: UM DIREITO À EDUCAÇÃO}

Existem muitos documentos internacionais que se preocupam com a educação e o direito à educação, em todos os seus níveis: infantil, fundamental, médio, superior, de adultos, etc. Apesar da importância de todos esses níveis para o desenvolvimento do ser humano e dos Estados, o presente trabalho estará a partir de agora, predominantemente voltado para a educação superior.

Isso porque, como será visto no capítulo seguinte, nas negociações comerciais internacionais, a ênfase é sempre dada para a liberalização do nível superior, diante da maior liberdade que possuem os países para tratar comercialmente deste subsetor no plano internacional. No próximo capítulo, essa escolha ficará mais clara, quando forem apresentados os objetivos da liberalização do comércio internacional de serviços em geral e suas exceções.

Mas, além do enfoque dado a este setor nas negociações comerciais, objetiva-se ainda demonstrar o papel importante exercido pela educação superior na sociedade, em especial para o direito ao desenvolvimento e, assim, ressaltar as obrigações do Estado e da comunidade internacional para com a defesa e a garantia do ensino superior como o direito humano que é.

Segundo dados da UNESCO, a educação superior passa por um processo de expansão sem precedentes de matrículas: a partir da segunda metade do século passado, o número de

\footnotetext{
${ }^{233}$ Stiglitz elenca cinco bens públicos globais fundamentais: (i) estabilidade econômica internacional; (ii) segurança internacional (estabilidade política); (iii) meio ambiente internacional; (iv) assistência humanitária internacional; e (v) conhecimento (1999).
} 
matrículas de estudantes no ensino superior aumentou em mais de seis vezes; de 13 milhões em 1960 para 85 milhões em $1995^{234}$.

Assim, evidente que os debates sobre a educação superior devem crescer juntamente com o setor, levados a diversas áreas: pedagógica, filosófica, psicológica e jurídica. Neste momento, a educação superior é analisada a partir de uma ótica jurídica, em especial sobre o seu tratamento do Direito Internacional dos Direitos Humanos e no Direito do Comércio Internacional.

\subsubsection{Reafirmando a educação superior como direito humano}

Visto anteriormente, durante a análise dos instrumentos internacionais sobre o direito à educação, que o ensino superior está previsto como parte integrante do direito humano à educação, devendo atender, assim, aos princípios internacionais determinados na Declaração Universal dos Direitos do Homem e no Pacto Internacional sobre Direitos Econômicos, Sociais e Culturais. Além disso, o fornecimento da educação superior também deverá apresentar os elementos essenciais da educação como direito humano, formulados pela ex-relatora especial das Nações Unidas para o direito à educação e utilizados pelos órgãos e organizações internacionais como paradigma para a medição da implementação deste direito no mundo.

Neste sentido, relembre-se que a Declaração Universal dispõe que o acesso aos estudos superiores deve estar aberto a todos em plena igualdade, em função do seu mérito ${ }^{235}$. Já no Pacto Internacional ${ }^{236}$, aprofunda-se o disposto na Declaração: "A educação de nível superior deverá igualmente tornar-se acessível a todos, com base na capacidade de cada um, por todos os meios apropriados e, principalmente, pela implementação progressiva do ensino gratuito".

Assim, evidente o tratamento do ensino superior como parte integrante de direito humano, o que lhe confere todas as características intrínsecas a esses direitos, como a universalidade, a não-discriminação e a irrenunciabilidade. Além disso, à educação

\footnotetext{
${ }^{234}$ UNESCO, Declaração Mundial sobre Educação Superior no Século XXI, 1998, Preâmbulo.

${ }^{235}$ Artigo 26, parágrafo $1^{\circ}$.

${ }^{236}$ Artigo 13, parágrafo $2^{\circ}$, alínea "c".
} 
superior também são aplicáveis os requisitos de disponibilidade, acessibilidade, aceitação e $\operatorname{adaptabilidade}^{237}$.

A grande diferença com relação aos demais níveis, é que o acesso à educação superior depende da capacidade individual de cada um, sendo isto verificado em função dos conhecimentos e experiência dos indivíduos. Além disso, ressalte-se a previsão de que o ensino superior deverá tornar-se progressivamente gratuito, ou seja, o Estado tem a obrigação de, gradativamente, tomar medidas para que todos aqueles que quiserem tenham acesso à educação superior gratuita.

A UNESCO reconhece e reafirma o ensino superior como parte integrante e componente fundamental do direito humano à educação, especialmente por meio de dois instrumentos: A Declaração Mundial sobre a Educação Superior para o Século XXI: Visão e Ação (World Declaration on Higher Education for the Twenty-First Century: Vision and Action) e o Marco Referencial de Ação Prioritária para a Mudança e o Desenvolvimento da Educação Superior (Framework for Priority Action for Change and Development in Higher Education) $)^{238}$.

A Declaração Mundial sobre a Educação Superior relembra que a educação é um direito de todos e destaca o papel da educação superior como fator de desenvolvimento dos países e na diminuição das desigualdades mundiais ${ }^{239}$.

Assim, evidente que a educação superior é componente indispensável do direito humano à educação, devendo ser protegida e promovida nos âmbitos interno e internacional. O desrespeito às disposições internacionais que dizem respeito à educação superior faz com que o direito à educação não seja plenamente realizado e aplicado. Por este motivo, qualquer estudo dedicado ao ensino superior deverá ter em mente a atenção aos princípios

${ }^{237}$ Observação Geral no 13 do Comitê de Direitos Econômicos, Sociais e Culturais, 1999, parágrafo 20 (14) (E/C.12/1999/10).

${ }^{238}$ Ambos os instrumentos foram adotados em 1998, por ocasião da Conferência Mundial sobre Ensino Superior (CMES): Visão e Ação, realizada em Paris.

${ }^{239}$ Recalling also the Universal Declaration of Human Rights which states in Article 26, paragraph 1, that 'Everyone has the right to education' and that 'higher education shall be equally accessible to all on the basis of merit', and endorsing the basic principles of the Convention against Discrimination in Education (1960), which, by Article 4, commits the States Parties to it to 'make higher education equally accessible to all on the basis of individual capacity'(...).

(...) Without adequate higher education and research institutions providing a critical mass of skilled and educated people, no country can ensure genuine endogenous and sustainable development and, in particular, developing countries and least developed countries cannot reduce the gap separating them from the industrially developed ones. Sharing knowledge, international co-operation and new technologies can offer 
e regras internacionais do Direito Internacional dos Direitos Humanos, sob pena de prejudicar o direito humano à educação, além de contribuir para que os violadores deste direito possuam mais argumentos na tentativa de justificar suas violações.

A seguir, será analisada a relação entre a educação superior e o desenvolvimento em todos os seus aspectos. $\mathrm{O}$ resultado desta análise visa reafirmar o direito à educação superior como parte fundamental do direito ao desenvolvimento, ou seja, quer-se concluir que os impactos sobre a força e a efetividade da educação superior como componente do direito humano à educação afetam incontestavelmente a realizabilidade do direito ao desenvolvimento.

\subsubsection{Educação superior e desenvolvimento}

O crescimento do setor educacional superior demonstra a relevância dos estudos que se preocupem com a qualidade e o acesso desse nível de educação aos indivíduos. Ainda mais, quando é possível evidenciar uma relação direta entre o direito humano à educação superior e o desenvolvimento.

Apesar disso, por mais paradoxal que possa parecer, demonstrar essa relação é uma tarefa que possui ao mesmo tempo certo grau de obviedade e complexidade ${ }^{240}$.

Tradicionalmente, costuma-se relacionar a educação ao desenvolvimento com enfoque principal dado ao papel da educação básica, o que faz com que todos os dispositivos internacionais e nacionais vigentes até o momento priorizem o ensino básico, como principal componente do direito à educação, indispensável ao desenvolvimento. Assim, diversas instituições internacionais, como o Banco Mundial, sempre indicaram que os países direcionassem seus investimentos prioritariamente para a educação básica, na busca pelo desenvolvimento, visando erradicar o analfabetismo ${ }^{241}$.

Essa preferência dada ao ensino básico fazia com que muitos acreditassem que priorizar a educação básica significava excluir a educação superior, uma vez que ao determinar o

new opportunities to reduce this gap. Preâmbulo, Declaração Mundial sobre Educação Superior no Século XXI, 1998.

${ }^{240}$ Ribeiro, 2005, p. 325.

${ }^{241}$ Banco Mundial, 1986. 
direcionamento dos recursos disponíveis, a educação básica sempre estaria em primeiro lugar, quando comparada à educação superior ${ }^{242}$.

Segundo Gustavo Ribeiro ${ }^{243}$, “a idéia de ser a educação básica a prioridade principal dos Estados, baseia-se, entretanto, em modelos puramente econométricos". Ocorre que atualmente a relação entre a educação superior e o desenvolvimento é um pouco mais óbvia por outros motivos, especialmente pelas próprias características da sociedade contemporânea, que deposita na ciência e na tecnologia papel fundamental, a ponto de contribuir para que ela seja chamada de "era do conhecimento", "sociedade de rede", "era da informação", entre outras.

Nesse sentido, se na sociedade atual, a ciência e a tecnologia são fundamentais para o desenvolvimento, e é na educação superior que se encontra a maior parte da produção científica, é inegável a relação intrínseca entre estes elementos ${ }^{244}$.

Importante ressaltar que essas evidências da relevância e do crescimento da educação superior, além de diversos estudos que ressaltam a importância da do ensino superior para o desenvolvimento da sociedade atual, fizeram com que a premissa de que o ensino básico deveria ser prioritário na ordem dos investimentos e financiamentos não fosse mais tão absoluta, como se a boa realização de um desses níveis fosse excludente da outra.

Gustavo Ribeiro discorre sobre a relação entre a educação superior e o desenvolvimento econômico, o desenvolvimento regional e o desenvolvimento pessoal, com o objetivo de reforçar a idéia de que é importante investir no setor ${ }^{245}$.

Neste sentido, lembra as palavras de Manuel Castells, que menciona a necessidade de se enxergar na educação superior como forma de política desenvolvimento, corroborando o entendimento sobre a importância da educação superior como fonte geradora de tecnologia, capaz de contribuir para o crescimento econômico e o desenvolvimento dos Estados.

Mas, tão ou mais importante que as contribuições da educação superior para o crescimento e desenvolvimento dos Estados é a sua relação com o fortalecimento e a qualificação da

\footnotetext{
${ }^{242}$ Robert Smith ilustra esta situação como uma "escolha de Sofia", vez que diante da escassez de recursos governamentais, o enfoque dado à universalização da educação básica e erradicação do analfabetismo não permitiria o financiamento da educação superior. (2003, p. 95-99).

${ }^{243}$ Ribeiro, 2005, p. 327.

${ }^{244}$ Ribeiro, 2005, p. 326.
} 
capacidade do homem de exigir e exercer suas liberdades individuais, já que a aquisição de novos conhecimentos leva à capacitação pessoal do indivíduo e ao aumento das suas possibilidades de escolhas.

$\mathrm{Na}$ verdade, educação superior é que torna possível que o ser humano se beneficie plenamente das vantagens que uma sociedade internacional interdependente e globalizada pode lhe oferecer.

Assim, a educação superior possui um papel fundamental para a concepção mais abrangente do desenvolvimento, que o encara como direito humano fundamental à dignidade humana.

Retome-se ainda o debate sobre os bens públicos internacionais. Visto que a educação é entendida como um bem público internacional, pois projeta externalidades de interesse público para toda a comunidade internacional. E esta constatação não é diferente para o setor específico da educação superior.

Alguns contestam o reconhecimento da educação superior como um bem público, por entender que este nível da educação não atende os requisitos característicos desses bens. Isso porque, o ingresso nas instituições de ensino superior poderiam ser restritas a alguns, excluindo outros e, como as vagas disponíveis são limitadas, o "consumo" por uma pessoa importaria na redução do "consumo" por outros. No entanto, esse entendimento é muito estreito, pois não reconhece que uma vez que o conhecimento torna-se disponível para uma pessoa, é impossível evitar que outros se aproveitem deste conhecimento mediante nenhum custo.

Tome-se, por exemplo, um médico, certamente formado em um curso superior. Não se pode evitar que o conhecimento adquirido por ele durante sua formação beneficie outras pessoas, como seus pacientes, que usufruem de sua capacidade técnica e perícia. Nada o impede de escrever um livro com o que aprendeu, o qual estará disponível para qualquer um.

Assim, se o enfoque é dado aos benefícios que o ensino superior pode trazer, e não ao serviço em si (ser admitido em um curso superior), a educação superior satisfaz os dois requisitos essenciais dos bens públicos ${ }^{246}$. Ainda que seja possível reduzir o número de

${ }^{245}$ Ribeiro, 2005, pp. 328 a 333.

246 Tilak, 2005, p. 8. 
vagas em universidades, não é possível impedir a distribuição dos benefícios que decorrem da educação superior fornecida aos poucos que conseguiram as vagas.

Jandhyala Tilak ${ }^{247}$ explica que o reconhecimento da educação superior como bem público fica mais clara ao se analisar as externalidades que ela produz, ou seja, os benefícios públicos $^{248}$ que ela traz, como por exemplo: (i) a educação superior contribui, por meio do ensino e da pesquisa, para a criação, o aprimoramento, a absorção e a disseminação do conhecimento; (ii) contribui ainda para a rápida industrialização da economia, pelo aprimoramento da força humana, desenvolvendo habilidades técnicas, profissionais e administrativas; (iii) também são fundamentais para a construção do caráter e da moral dos indivíduos; (iv) colabora para a formação de um Estado forte, pela produção de melhores cidadãos, que podem participar ativamente das atividades sociais, econômicas, civis, políticas e culturais da sociedade, além de ajudar a entender, interpretar, promover, preservar e disseminar culturas históricas nacionais, regionais e internacionais, em um contexto de pluralismo e diversidade cultural; (v) contribui para o desenvolvimento e aprimoramento da educação em todos os níveis.

Como todas essas externalidades são de interesse público, sejam elas benefícios para o ser humano em sua individualidade ou para a sociedade, a educação superior é um serviço público. E, como tal, gera diversos benefícios sociais, políticos, econômicos e culturais, que são também verdadeiros bens públicos por si só, como, por exemplo, a redução da taxa de criminalidade, a coesão social e apreciação da diversidade, melhores condições de saúde, cidadãos bem informados e críticos, maior participação pública, força de trabalho qualificada, crescimento dos níveis de consumo, entre outros.

Assim, evidente que a educação superior traz benefícios relacionados à saúde, ao crescimento populacional, à democracia, aos direitos humanos, à estabilidade social, à pobreza, à desigualdade, ao meio ambiente, ao crime, além do crescimento econômico ${ }^{249}$, ou seja, a educação superior, como bem público internacional de grande valor e importância que é, traz benefícios a todos os aspectos do desenvolvimento entendido como direito humano. Mais do que isso, o direito humano à educação superior como bem público

\footnotetext{
${ }^{247}$ Tilak, 2005, p. 9-14.

${ }^{248}$ Ressalte-se que a educação como bem público não traz apenas benefícios públicos, mas gera benefícios privados também, ao contrário dos bens privados que produzem exclusivamente benefícios privados.

${ }^{249}$ Ressalte-se que, como bem lembra Tilak, as externalidades ou benefícios públicos da educação superior em geral, não são mensuráveis, ou seja, não podem ser quantificadas, mas não há dúvidas de que elas existem e, portanto, não podem ser encaradas como um discurso utópico (2005, p. 13).
} 
não é apenas um meio para o direito ao desenvolvimento, como constitui em si o próprio desenvolvimento.

Por fim, cumpre relembrar que a educação superior também exerce papel fundamental para a aferição do IDH, já que, conforme mencionado anteriormente, a educação é uma das bases de cálculo deste índice, sendo que a análise do nível educacional de um país é feita com base no grau de analfabetismo e no número de matrículas feitas em todos os níveis da educação, incluindo, portanto, as matrículas no ensino superior.

O problema do direito à educação superior, porém, assim como o direito à educação em qualquer outro nível e o próprio direito ao desenvolvimento, é que sua efetividade fica bastante comprometida em razão da situação política, econômica e social dos Estados. Assim, ressalta-se, mais uma vez, que a cooperação internacional em uma sociedade solidária, que busca promover e proteger os direitos humanos de forma plena em todos os espaços, é mais do que necessária, é urgente. Somente dentro de uma ordem internacional mais justa é que a educação superior poderá exercer seu papel de forma mais efetiva para o desenvolvimento como direito humano.

Por este motivo, o tratamento deste setor em qualquer tipo de organização internacional seja em organizações internacionais voltadas para a defesa dos direitos humanos, ou para a paz ou para o comércio internacional - deve levar em consideração o seu peso na implementação do direito ao desenvolvimento.

Além disso, as instituições de ensino superior devem sempre buscar exercer suas funções com vistas aos objetivos do desenvolvimento como direito humano. Daí a importância de se analisar o papel do Estado, no caso, do brasileiro, e do setor privado no ensino superior, o que se passa a fazer adiante.

\subsection{A EDUCAÇÃO COMO DIREITO HUMANO NO BRASIL}

Já dizia Bobbio ${ }^{250}$ que os direitos humanos nascem como direitos naturais universais e desenvolvem-se como direitos positivos particulares (quando cada constituição incorpora declarações de direitos), para finalmente encontrarem sua plena realização como direitos positivos universais.

${ }^{250}$ Bobbio, 2004, p. 48-49. 
Dessa forma, percebe-se que é fundamental para a realização plena dos direitos humanos, que estes sejam incorporados pelos países signatários das declarações internacionais de direitos humanos, sendo inseridos como normas cogentes do ordenamento jurídico interno desses Estados.

No Brasil, assim como na maioria dos países democráticos, essa positivação interna dos direitos humanos se dá por meio da previsão da garantia, promoção e proteção desses direitos em suas Constituições.

A Constituição brasileira de 1988 prevê já no "caput" do seu artigo $1^{\circ}$, que o Brasil é um Estado democrático de direitos, sendo que um dos seus pilares é a garantia dos direitos humanos, sendo impossível que qualquer lei reduza os direitos humanos previstos na Carta Magna.

O direito à educação é previsto, na Constituição Federal, em seu artigo $6^{0^{251}}$, como um direito fundamental de natureza social. Sua proteção tem, portanto, uma dimensão que ultrapassa a consideração de interesses meramente individuais. Assim, o direito brasileiro reconhece a educação como um bem público comum ${ }^{252}$.

Os artigos 205 e 214 regulamentam a atividade da educação, estabelecendo princípios e regras que devem guiar o Estado, os prestadores de serviços educacionais e os indivíduos quando envolvidos na atividade educacional. Neste sentido, o artigo 205 dispõe que o poder público, como titular do dever jurídico correlato ao direito à educação, deverá organizar-se para fornecer os serviços educacionais a todos, de acordo com os princípios estatuídos na Constituição Federal, sempre no sentido de ampliar cada vez mais as possibilidades de todos que venham a exercer igualmente este direito.

O artigo 206, por sua vez, consagra os princípios da igualdade de condições para o acesso e permanência na escola, a gratuidade do ensino em estabelecimentos oficiais, a valorização dos profissionais do ensino público e a garantia do padrão de qualidade ${ }^{253}$.

\footnotetext{
${ }^{251} \mathrm{O}$ art. $6^{\circ}$, da Constituição Federal prevê que: "São direitos sociais a educação, a saúde, o trabalho, a moradia, o lazer, a segurança, a previdência social, a proteção à maternidade e à infância, a assistência aos desamparados, na forma desta Constituição".

${ }^{252}$ Duarte, 2007, p. 697.

${ }^{253}$ Estes princípios são reafirmados na Lei de Diretrizes e Bases do Ensino Nacional em seu artigo $3^{\circ}$, que dispõe: "O ensino será ministrado com base nos seguintes princípios: I - igualdade de condições para o acesso e permanência na escola; II - liberdade de aprender, ensinar, pesquisar e divulgar a cultura, o pensamento, a arte e o saber; III - pluralismo de idéias e de concepções pedagógicas; IV - respeito à liberdade e apreço à tolerância; V - coexistência de instituições públicas e privadas de ensino; VI -
} 
No que tange especificamente à educação superior, a Constituição Federal determina que o dever do Estado com a educação será efetivado com a garantia de acesso aos níveis mais elevados do ensino, da pesquisa e da criação artística (artigo 208, inciso V).

Por sua vez, o artigo 43, da Lei de Diretrizes e Bases da Educação Nacional determina que a educação superior tem por finalidade:

I - estimular a criação cultural e o desenvolvimento do espírito científico e do pensamento reflexivo;

II - formar diplomados nas diferentes áreas de conhecimento, aptos para a inserção em setores profissionais e para a participação no desenvolvimento da sociedade brasileira, e colaborar na sua formação contínua;

III - incentivar o trabalho de pesquisa e investigação científica, visando o desenvolvimento da ciência e da tecnologia e da criação e difusão da cultura, e, desse modo, desenvolver o entendimento do homem e do meio em que vive;

IV - promover a divulgação de conhecimentos culturais, científicos e técnicos que constituem patrimônio da humanidade e comunicar o saber através do ensino, de publicações ou de outras formas de comunicação;

$\mathrm{V}$ - suscitar o desejo permanente de aperfeiçoamento cultural e profissional e possibilitar a correspondente concretização, integrando os conhecimentos que vão sendo adquiridos numa estrutura intelectual sistematizadora do conhecimento de cada geração;

VI - estimular o conhecimento dos problemas do mundo presente, em particular os nacionais e regionais, prestar serviços especializados à comunidade e estabelecer com esta uma relação de reciprocidade;

VII - promover a extensão, aberta à participação da população, visando à difusão das conquistas e benefícios resultantes da criação cultural e da pesquisa científica e tecnológica geradas na instituição.

Também é importante relembrar que o Brasil ratificou o Pacto Internacional sobre Direitos Econômicos, Sociais e Culturais, de 1966, sendo que este documento foi incorporado na legislação brasileira como Decreto Legislativo $n^{\circ} 592$, promulgado em 06 de dezembro de 1992. Isso significa que, se não bastasse o fato de o Brasil estar comprometido internacionalmente pelo simples fato de se Estado Membro da ONU e de ter participado da promulgação das declarações internacionais sobre o direito à educação, o ordenamento jurídico brasileiro incorporou os princípios internacionais corroborados no Pacto Internacional, colocando-os em equivalência às obrigações internas do Estado.

gratuidade do ensino público em estabelecimentos oficiais; VII - valorização do profissional da educação escolar; VIII - gestão democrática do ensino público, na forma desta Lei e da legislação dos sistemas de ensino; IX - garantia de padrão de qualidade; X-valorização da experiência extra-escolar; XI - vinculação entre a educação escolar, o trabalho e as práticas sociais". 
Assim, verifica-se que a Constituição Federal, em seus artigos sobre a educação como direito fundamental de natureza social, corrobora os compromissos assumidos pelo Brasil internacionalmente sobre o direito humano à educação, incorporando seus princípios da universalidade, gratuidade ${ }^{254}$ e progressividade.

Além disso, outras legislações infraconstitucionais também regulamentam a educação no Brasil e a almejam a proteção e a promoção do direito ao desenvolvimento, em especial, a Lei de Diretrizes e Bases da Educação Nacional (Lei $n^{\circ}$ 9394/96), que especifica as normas e princípios dispostos na Constituição. E ainda, contam-se com as resoluções do Conselho Nacional da Educação e os conselhos estaduais e municipais.

Dessa forma, evidente que os princípios e observações internacionais pelo direito à educação como direito humano e bem público, inclusive quanto à educação superior, devem ser observadas no território brasileiro. Mas, como bem destaca César Pereira da Silva Machado $\mathrm{Jr}^{255}$ : “um simples olhar para a realidade brasileira é suficiente para compreendermos quão distante nos encontramos da efetivação da educação como direito de todos".

Isso porque não adianta esperar os resultados do reconhecimento do direito à educação como direito humano na legislação brasileira e da implementação de políticas públicas no setor educacional, se não forem oferecidas as condições necessárias para a fruição desse direito. Assim, "a satisfação do direito à educação não se esgota na realização do seu aspecto meramente individual (garantia de uma vaga na escola, por exemplo), mas abrange a realização de prestação positivas de natureza diversa por parte do poder público, num processo que se sucede no tempo",256.

Dessa forma, nas conclusões de Clarice Seixas Duarte ${ }^{257}$, a educação, reconhecida como direito fundamental de natureza social pelo ordenamento jurídico brasileiro:

a) ocupa papel de destaque no ordenamento jurídico, servindo mesmo como razão de ser de toda a ordem jurídica, juntamente com os demais direitos fundamentais; b) tem aplicabilidade imediata, embora sua realização integral só possa se dar de forma progressiva; c) não pode ser suprimida do ordenamento jurídico por meio de emenda constitucional; d) pertence a todos, mas deve priorizar categorias de pessoas que se encontram numa mesma posição de carência ou vulnerabilidade; e)

\footnotetext{
${ }^{254}$ O Artigo 205, em seu $§ 2^{\circ}$, prevê inclusive uma sanção ao Estado pelo descumprimento da obrigação de oferecer a educação primária gratuita a todos.

${ }^{255}$ Machado Jr., 2003, p.17.

${ }^{256}$ Duarte, 2007, p. 710.

${ }^{257}$ Duarte, 2007, p. 710-711.
} 
tem como sujeito passivo o Estado; e) realiza-se por meio de políticas públicas ou programas de ação governamental; g) vincula todos os poderes públicos (Executivo, Legislativo e Judiciário), que devem adotar medidas - legislativas, técnicas e financeiras - até o máximo dos recursos disponíveis, para a satisfação daquilo que foi eleito como prioritário (núcleo mínimo obrigatório), reconhecendo o direito à educação como um verdadeiro direito.

Assim, uma vez evidenciado que o direito à educação está amplamente previsto no ordenamento jurídico brasileiro como um direito humano, quais as implicações desse tratamento para a sociedade, para os fornecedores de serviços educacionais e para o Estado? O que se pode exigir desses atores pela promoção e garantia desse direito humano?

\subsection{A PARTICIPAÇÃO PRIVADA NA EDUCAÇÃO E O PAPEL DO ESTADO}

O Direito Internacional dos Direitos Humanos não vai contra nem a favor da privatização da prestação de serviços públicos, como a educação em todos os seus níveis. Isso porque os próprios dispositivos dos instrumentos internacionais que prevêem o direito à educação como direito humano já reconhecem que, com exceção do nível primário, a educação poderá não ser gratuita.

Isso devido ao caráter progressivo e contextual dos direitos econômicos, sociais e culturais, que devem ser garantidos gradativamente e que, de certa forma, dependem das condições atuais do Estado, para que possam ser efetivamente implementados ${ }^{258}$.

No entanto, esses mesmos dispositivos também ressaltam que, uma vez que trata-se de um bem e um serviço público, o Estado é o principal responsável pela promoção e proteção da educação, devendo garantir o seu fornecimento em todos os níveis à sua população. Por isso, mesmo em caso de delegação ou privatização da prestação dos serviços educacionais, o Estado permanece com a obrigação de avaliar as incidências financeiras e econômicas sobre o direito à educação, devendo fiscalizar as instituições públicas e privadas no exercício dessa função pública. O Estado deve regulamentar e controlar a prestação dos serviços educacionais, exigindo atenção aos patamares mínimos, a fim de que o direito à educação como direito humano seja respeitado e que seja possível a realização de seus objetivos pelo desenvolvimento, principalmente quando os serviços são prestados por entidades com fins lucrativos.

\footnotetext{
${ }^{258}$ Ressalte-se, mais uma vez, porém, que o status econômico e social desprivilegiado de um país, por si só, não pode servir de desculpa para que não empregue esforços para a realização dos direitos humanos.
} 
Isso significa que, apesar de poderem delegar e privatizar o fornecimento da educação, de modo que os serviços educacionais possam ser prestados por entidades privadas, os Estados nunca podem privatizar as suas obrigações quanto ao direito humano à educação $^{259}$.

A Declaração Mundial sobre Educação Superior no Século XXI, por sua vez, dispõe que:

Artigo 14 - Financiamento da educação superior como serviço público

$\mathrm{O}$ financiamento da educação superior demanda tanto recursos públicos como privados. O papel do Estado permanece essencial neste particular.

(a) A diversificação dos recursos de financiamento reflete o apoio que a sociedade fornece à educação superior e deve ser fortalecido para garantir que o desenvolvimento da educação superior, para aumentar sua eficiência e para manter sua qualidade e relevância. $\mathrm{O}$ apoio público à educação superior e à pesquisa permanece essencial para garantir o alcance equilibrado dos objetivos sociais e educacionais.

(b) A sociedade como um todo deve apoiar a educação em todos os níveis, incluindo a educação superior, dado o seu papel na promoção do desenvolvimento sustentável social, cultural e econômico. A mobilização para este propósito depende da consciência pública e do envolvimento dos setores público e privado da economia, parlamentos, a mídia, organizações governamentais e nãogovernamentais, estudantes e instituições, famílias e todos os atores sociais envolvidos com a educação superior ${ }^{260}$.

Evidente, portanto, que a Declaração reconhece a importância do setor privado para o cumprimento dos objetivos sociais, humanos e de desenvolvimento da educação superior, mas reafirma que o Estado permanece exercendo papel essencial para a realização da educação superior como direito humano.

No ordenamento jurídico brasileiro, não há qualquer restrição à prestação dos serviços educacionais pela iniciativa privada ${ }^{261}$, que deverá cumprir apenas às exigências impostas a

\footnotetext{
${ }^{259}$ Monteiro, 2003, p. 779

260 Tradução livre de:

"Article 14 - Financing of higher education as a public service
}

The funding of higher education requires both public and private resources. The role of the state remains essential in this regard.

(a) The diversification of funding sources reflects the support that society provides to higher education and must be further strengthened to ensure the development of higher education, increase its efficiency and maintain its quality and relevance. Public support for higher education and research remains essential to ensure a balanced achievement of educational and social missions.

(b) Society as a whole must support education at all levels, including higher education, given its role in promoting sustainable economic, social and cultural development. Mobilization for this purpose depends on public awareness and involvement of the public and private sectors of the economy, parliaments, the media, governmental and non-governmental organizations, students as well as institutions, families and all the social actors involved with higher education". Declaração Mundial sobre Educação Superior no Século XXI, 1998, artigo 14.

${ }^{261}$ A Lei de Diretrizes e Bases da Educação Nacional especifica o que são instituições privadas de ensino, em seu artigo 20, separando-as em particulares em sentido estrito, comunitárias, confessionais e filantrópicas. "Art. 20. As instituições privadas de ensino se enquadrarão nas seguintes categorias: I - particulares em sentido estrito, assim entendidas as que são instituídas e mantidas por uma ou mais pessoas físicas ou 
todas as instituições de ensino no Brasil ${ }^{262}$. Neste sentido, o artigo 209 da Constituição Federal dispõe que: "O ensino é livre à iniciativa privada, atendidas às seguintes condições: I - cumprimento das normas gerais da educação nacional; II - autorização e avaliação de qualidade pelo Poder Público"263.

Ressalte-se, no entanto, que a participação do Estado, como financiador da educação no Brasil, é obrigatória no sentido de que há um mínimo de recursos que deverão ser direcionados ao ensino ${ }^{264}$.

Além disso, por ter incorporado ${ }^{265}$ as disposições do Pacto Internacional sobre os Direitos Econômicos, Sociais e Culturais, o Brasil também reconhece a necessidade de implementar progressivamente a educação superior gratuita a todos. Evidente, portanto, que o ordenamento jurídico do Brasil mantém a educação como direito público, que deverá sempre contar com a participação Estatal.

Mesmo assim, segundo dados do Instituto Nacional de Estudos e Pesquisas Educacionais Anísio Teixeira (INEP), em 2004, o número total de instituições de ensino superior no Brasil era de 2013, sendo que $224(11,1 \%)$ são públicas (entre federais, estaduais e municipais), $1401(69,6 \%)$ são particulares e 388 (19,3\%) são comunitárias ${ }^{266}$.

jurídicas de direito privado que não apresentem as características dos incisos abaixo; II - comunitárias, assim entendidas as que são instituídas por grupos de pessoas físicas ou por uma ou mais pessoas jurídicas, inclusive cooperativas de pais, professores e alunos, que incluam em sua entidade mantenedora representantes da comunidade; III - confessionais, assim entendidas as que são instituídas por grupos de pessoas físicas ou por uma ou mais pessoas jurídicas que atendem a orientação confessional e ideologia específicas e ao disposto no inciso anterior; IV - filantrópicas, na forma da lei."

${ }^{262}$ Essas exigências referem-se aos parâmetros mínimos determinados pelo Estado, aos requisitos para a abertura de instituições de ensino ou de empresas (direito comercial) no Brasil, entre outras.

${ }^{263} \mathrm{O}$ artigo $7^{\circ}$, da Lei de Diretrizes e Bases da Educação Nacional insere ainda mais uma condição: "capacidade de autofinanciamento, ressalvado o previsto no art. 213 da Constituição Federal".

264 Artigo 212, da Constituição Federal: "A União aplicará, anualmente, nunca menos de dezoito, e os Estados, o Distrito Federal e os Municípios vinte e cinco por cento, no mínimo, da receita resultante de impostos, compreendida a proveniente de transferências, na manutenção e desenvolvimento do ensino.

${ }^{265}$ Ressalte-se que, a partir da Emenda Constitucional $\mathrm{n}^{\circ} 45$, de 2004, os tratados internacionais de direitos humanos passam a ter um novo status no ordenamento jurídico brasileiro, passando a ser reconhecidos como normas constitucionais, quando aprovados pelo mesmo processo legislativo das emendas constitucionais. Há um debate na doutrina e na jurisprudência sobre a situação dos tratados internacionais de direitos humanos aprovados anteriormente à EC 45, como é o caso do Pacto Internacional sobre os Direitos Econômicos, Sociais e Culturais, que foge aos objetivos do presente trabalho. No entanto, acredita-se, na opinião desta autora, que a intenção da EC 45/04 era conceder maior grau de efetividade aos direitos humanos, buscando cumprir com seus compromissos de proteção e promoção destes direitos. Assim, uma vez que os direitos humanos são indissociáveis, interdependentes e universais, não há sentido em tratá-los como nada menos do que normas constitucionais no ordenamento jurídico brasileiro, independentemente da época em que foram incorporados, já que são normas mais benéficas aos indivíduos, sujeito principal dos direitos humanos.

266 INEP, Sistema de Estatísticas Educacionais, 2004. Disponível em: $<$ http://www.edudatabrasil.inep.gov.br/index.htm>. 
Essa predominância da iniciativa privada no ensino superior é resultado da adoção pelo governo brasileiro da política de focalização dos recursos públicos no ensino fundamental, em concordância com as orientações do Banco Mundial, que atendem duplamente às necessidades do mercado. De um lado, permite que a população mais pobre tenha acesso a um mínimo de conhecimento para se inserir no mercado de trabalho ${ }^{267}$ e, de outro, deixa um vasto campo (mercado) a ser explorado pela iniciativa privada, nos ensinos técnico e superior $^{268}$.

Assim, a política educacional no Brasil, que é a mesma de quase todos os países do mundo, logrou criar um mercado extremamente atraente para a iniciativa privada no setor do ensino superior.

Estudos $^{269}$ indicam que, a educação em geral movimenta cerca de US\$ 2,2 trilhões por ano, e, em 2001, empregava cerca de 5\% da mão-de-obra mundial. Além disso, acredita-se que a demanda mundial pelo ensino superior deve chegar a 160 milhões de pessoas em 2025, sendo que, em 2004, esse número era de 84 milhões. A grande maioria dessa demanda encontra-se concentrada nos países em desenvolvimento ${ }^{270}$.

Nos últimos cinqüenta anos, a educação superior cresceu catorze vezes, enquanto o gasto público com o setor tem-se mantido estável ou até mesmo decresceu, o que confirma o grande espaço ocupado pela iniciativa privada.

Outro estudo destaca que, em 2001, a iniciativa privada movimentava, em todo o mundo, $20 \%$ do mercado da educação, em torno de US\$ 400 bilhões, sendo que Brasil, China e Índia seriam os mercados mais prósperos para investimentos no ensino superior, em virtude de seu grande contingente populacional, aliado à insuficiência de recursos públicos nacionais para o setor ${ }^{271}$.

\footnotetext{
${ }^{267}$ Ressalte-se que esta política nem sempre produz os efeitos almejados, qual seja, de inserir a população mais pobre no mercado de trabalho, pois há pouco ou nenhum crescimento ou oferta de empregos.

${ }^{268}$ Haddad e Graciano, 2004, p. 68.

${ }^{269}$ Essas informações foram tiradas do estudo da consultoria Merryl Linch, intitulado Stimulating Investment in Global Education.

${ }^{270} \mathrm{O}$ estudo da Merryl Linch mostra que, em 2004, o maior índice de privatização da educação superior pertence às Filipinas, onde $94 \%$ das matrículas em instituições de ensino superior ficam a cargo da iniciativa privada. O Brasil ficou em terceiro lugar, com $70 \%$ das matrículas em instituições privadas, perdendo apenas para a Coréia (78\%), além das Filipinas, e seguido da Indonésia (63\%), Colômbia (61\%), Índia (60,5\%), Nicarágua (42\%), Peru (33\%), Chile (28\%), Nepal (24\%), Guatemala (18\%), Tailândia (17\%), México (16\%), Argentina (15\%) e Malásia (12\%).

${ }^{271}$ Haddad e Graciano, 2004, p. 69.
} 
No Brasil, o setor do ensino superior movimentou cerca de R \$20,5 bilhões no ano de 2008 e cresceu em média $157 \%$ na última década, graças ao sistema de educação privada, que aumentou o número de vagas e instituições. Estima-se que, entre o final da década de 1990 até 2002, a cada semana, foram abertas, em média, três instituições de ensino superior particulares no Brasil $^{272}$.

É bem verdade que o crescimento da participação da iniciativa privado no ensino superior brasileiro não necessariamente precisaria ser algo ruim. Como visto, a iniciativa privada é reconhecida tanto no âmbito interno como no internacional como importante fator para manter a diversidade do ensino e atender ao princípio da liberdade de escolha dos indivíduos quanto ao tipo de educação superior que queiram cursar.

No entanto, a visualização do ensino superior como mercado atraente no Brasil, cuja margem de lucro é estimada em $25 \%^{273}$, já aponta para o desvirtuamento dos princípios e normas nacionais e internacionais da educação superior. Isso porque muitas dessas instituições privadas não têm atendido aos requisitos mínimos determinados pela legislação brasileira, porém permanecem exercendo a função pública de prestadores de serviços educacionais.

É o que ocorre, por exemplo, com as universidades privadas. Segundo dados do Censo da Educação Superior 2006 (mais recente ${ }^{274}$ ), apenas 37 das 86 universidades privadas cumprem a exigência legal de ter um terço dos docentes trabalhando em regime integral, exigência esta prevista na Lei de Diretrizes e Bases da Educação Nacional, cujo objetivo é incentiva a pesquisa, requisito obrigatório nas universidades (ao contrário das faculdades e centros universitários, a quem não são feitas tais exigências).

O não cumprimento desta determinação pode reduzir em até $40 \%$ a folha de pagamentos da instituição $^{275}$, mas pode fazer com que percam o título de universidade, caso não se

\footnotetext{
${ }^{272}$ Há uma enorme concentração do mercado: menos de 5\% das grandes instituições de ensino privadas agregam quase metade das matrículas efetuadas no setor privado, enquanto as $50 \%$ menores instituições detêm apenas $5 \%$ do total de matriculas. As dez maiores universidades particulares têm mais de 440 mil alunos matriculados $(18,1 \%$ do total) e a somatória de seus faturamentos gira em torno de $21 \%$ do mercado (Monteiro e Braga, 2003).

${ }^{273}$ Pajara, 2003 e Studart, 2002.

${ }^{274}$ O Censo da Educação Superior 2007 está na fase final de elaboração. Segundo informações do site do INEP, a divulgação da sinopse estatística do documento estava prevista para final de novembro de 2008, porém até o momento esses dados não foram divulgados. Disponível em: $<$ http://www.inep.gov.br/superior/censosuperior/>. Acesso em: 17 jan. 2009.

${ }^{275}$ Studart, 2002.
} 
adéqüem às determinações. No entanto, até o momento, o Ministério da Educação e Cultura (MEC) não reavaliou ou descredenciou nenhuma instituição ${ }^{276}$.

Por outro lado, nas 90 universidades públicas do censo, apenas seis não cumprem a lei.

Parece óbvio afirmar que o descumprimento dessa determinação pelas instituições privadas é altamente prejudicial aos estudantes e, conseqüentemente, à sociedade como um todo, vez que prejudica o bom desempenho dos alunos. Mas, para comprovar tal afirmação, os resultados do Enade (exame aplicado aos alunos pelo governo federal) demonstram que nas dez instituições com menor proporção de docentes em tempo integral, as médias dos alunos de cada universidade variaram entre 2,5 e 3,3 (em uma escala de 0 a 5). Já nas instituições com maior número de docentes em tempo integral, a variação foi de 3,5 a $4,4^{277}$.

É evidente, portanto, que a concessão do serviço público da educação superior às instituições privadas nem sempre pode contribuir para o bom desempenho da educação e para o seu reconhecimento e a sua afirmação como direito humano, cujo objetivo final é permitir o pleno desenvolvimento dos indivíduos. Ao contrário, pode prejudicar e violar o direito humano à educação.

Por este motivo, a educação deve continuar a ser considerada uma responsabilidade das autoridades e como um serviço público pela esmagadora maioria dos governos do planeta. Além disso, as propostas que vão no sentido de uma maior liberalização limitam-se geralmente ao ensino pós-obrigatório e acentuam o fato de o ensino dispensado pelo setor privado dever complementar, e não substituir, o ensino público.

Como bem ressalta a relatora especial sobre o direito à educação para o Comitê dos Direitos do Homem, quando se comercializa, a educação rege-se pelo Direito Privado. Porém, os direitos humanos pertencem intrinsecamente aos seres humanos e regem-se pelo Direito Público, não pelo privado. E tanto no plano interno como no plano internacional, a preocupação com a educação como serviço público acentuou a necessidade de reafirmar e reforçar a educação como direito humano. ${ }^{278}$

\footnotetext{
${ }^{276}$ Folha de São Paulo, 12 mai. 2008.

${ }^{277}$ Folha de São Paulo, 12 mai. 2008.

${ }^{278}$ E/CN.4/2002/60, par. 20, 21, 36.
} 
Daí a necessidade de o Estado tornar-se mais ativo e efetivo no controle dessas instituições e manter-se livre para instituir outras políticas públicas e normas para fazer valer o direito humano à educação superior. O que ocorreria, então, se o Brasil passasse a assumir maiores compromissos no âmbito da OMC? É o que se pretende discutir no próximo capítulo.

\subsection{EDUCAÇÃO E COMÉRCIO INTERNACIONAL: UMA INTRODUÇÃO À CONTRADIÇÃO}

Antes de iniciar o a análise e o debate sobre o comércio internacional de serviços educacionais no âmbito da OMC, convém traçar algumas primeiras constatações sobre a atual relação entre o comércio internacional e a educação.

Foi visto que o direito à educação é um direito de todos. Da mesma forma, somos todos responsáveis pelo direito à educação e, portanto, estamos obrigados a protegê-lo e realizálo.

Percebe-se, portanto, que a comunidade internacional, nela inserida a OMC e seus países membros, e as relações de comércio internacional em geral, devem guiar-se pela proteção e garantia do direito à educação, sendo que todos são solidariamente responsáveis pelos baixos níveis de escolaridade nos países em desenvolvimento e de menor desenvolvimento relativo, devendo buscar maneiras de contribuir para a melhoria desses números, pela promoção de relações internacionais mais justas.

Ocorre que os altos valores envolvidos na prestação de serviços educacionais pela iniciativa privada, em especial, no nível superior, tem atraído cada vez mais a atenção de verdadeira empresas multinacionais que se especializaram no setor educacional como prestadoras do ensino superior em diversas partes do mundo.

O grupo estadunidense Apollo International, por exemplo, é um dos maiores conglomerados de educação no mundo e vem comprando diversas instituições de ensino superior no mundo todo, inclusive no Brasil ${ }^{279}$, onde se associou à Faculdade Pitágoras, de Minas Gerais. Além disso, o grupo atua no México, na Holanda, na Alemanha e na Índia.

\footnotetext{
${ }^{279}$ Em 2008, o grupo fez uma oferta de aproximadamente R \$ 2,5 bilhões pelo grupo Objetivo, maior empresa de educação no Brasil, dono do colégio Objetivo e da Universidade Paulista (UNIP), contando com mais de 130.000 alunos, 27 campi e 700 escolas. (Portal Exame, 18 jun. 2008).
} 
Nos EUA, o Apollo é dono de universidades e escolas em quarenta estados e teve em 2007, um faturamento de US\$2,7 bilhões ${ }^{280}$.

Conforme mencionado anteriormente, os países em desenvolvimento e de menor desenvolvimento relativo são os mais almejados, vez que possuem alta demanda pelos serviços educacionais e pouca oferta pelo setor público.

O "mercado" promissor em que se constitui o ensino superior brasileiro já foi descoberto e está sendo explorado pelo capital internacional, associado ao nacional. O mercado brasileiro de ensino superior oferece ainda a possibilidade de serem constituídos centros universitários $^{281}$ que, diferentemente das universidades, não precisam desenvolver atividades de pesquisa, o que pode reduzir a folha de pagamentos da instituição em até $40 \%$, conforme já mencionado anteriormente.

Ressalte-se que, não há no ordenamento jurídico brasileiro qualquer dispositivo legal que vede que instituições estrangeiras de ensino superior venham a prestar seus serviços no Brasil. Da mesma forma, não há ainda qualquer limitação à participação estrangeira no capital das instituições de ensino superior sediadas no Brasil ${ }^{282}$.

Já existem, pelo menos, seis instituições no território brasileiro com grande parte do capital na mão de empresas e grupos estrangeiros, sem contar as faculdades e escolas menores que as instituições maiores vêm comprando com o aporte de recursos estrangeiros ${ }^{283}$. Uma delas é a Anhembi Morumbi que, em 2005, teve 51\% de sua participação comprada pelo grupo Laureate (EUA).

Outras instituições obtiveram participação estrangeira em seu capital por meio da venda de ações na bolsa de valores. É o caso da Anhanguera ${ }^{284}$ (primeira instituição de ensino superior do país a abrir o capital na bolsa de valores de São Paulo) e da Estácio de Sá, segunda maior instituição de ensino superior privado no país.

\footnotetext{
${ }^{280}$ Portal Exame, 18 jun. 2008.

${ }^{281}$ Os centros universitários estão previstos na Lei de Diretrizes e Bases da Educação Nacional e no Decreto $n^{\circ} 2.207$, de 15 de abril de 1997, que, em seu artigo $4^{\circ}$, dispõe sobre a organização acadêmica das instituições de ensino superior e, em seu artigo $6^{\circ}$ define o que são centros universitários.

${ }^{282}$ Já existe, porém, um projeto de reforma universitária no Ministério da Educação e Cultura, em trâmite no Congresso Nacional desde 2006, para limitar a participação estrangeira a 30\% do capital volante das instituições de ensino superior em território brasileiro, mas está parado na Câmara (para maiores informações sobre a reforma universitária, ver <http://mecsrv04.mec.gov.br/reforma/default.asp $>$. Outra proposta proibiria qualquer capital internacional em instituições de ensino superior no Brasil.

${ }^{283}$ Folha de São Paulo, 27 jul. 2008.

${ }^{284}$ As ações da Anhanguera já cresceram mais de 50\% e há previsões de que o seu faturamento para 2008 , seja de R $\$ 600$ milhões.
} 
Outra questão importante e relativamente recente que envolve o setor do ensino superior é o seu "mercado online", representado pelo crescimento do ensino à distância no mundo, que, em 2000, movimentou, pelas vias virtuais, US\$ 49,4 bilhões.

A educação à distância por meios virtuais (e-learning) tem obtido bastante sucesso no mundo por envolver baixo custo na prestação dos serviços, já que se utiliza de estruturas e conteúdos já existentes, que podem ser disseminados para qualquer outro lugar do mundo, por meio da Internet.

O e-learning tem sido utilizado para vários tipos de educação - especialmente a capacitação de funcionários -, mas ressalte-se, para o presente trabalho, seu crescimento nas universidades virtuais. A Universidade das Nações Unidas (UNU) ${ }^{285}$ estimou que o custo para o estabelecimento de uma universidade totalmente online, para cerca de 2 mil estudantes, é de US\$ 15 milhões, incluindo pessoal, computadores e localização. O valor unitário dos cursos varia de US\$ 50 mil a US\$ 500 mil, com uso de sistemas mais avançados. Já o retorno desses investimentos pode ser mensurado pela Univerity of Phoenix, que, em 2002, teve lucro de US\$ 23,6 milhões.

No entanto, Paul Delany ${ }^{286}$ demonstra preocupação com a disseminação do ensino à distância pelos meios virtuais. Segundo o autor, algumas instituições de ensino superior freqüentadas pelas elites econômicas dos países ricos utilizam seu nome, como instituições de qualidade pelo mundo - verdadeira "marca" - para disponibilizarem parcialmente e com baixa qualidade, seus serviços para estudantes dos países pobres. É o que ele chama de "the Brand-Name University".

Percebe-se, portanto, que o setor do ensino superior já encontra-se bastante aberto à iniciativa privada estrangeira, contando com investimentos de empresas multinacionais e com instituições com o capital dominado por empresas estrangeiras. Esta é também a exata situação do Brasil, importante alvo dos grandes conglomerados empresariais no setor educacional.

Não há, porém, qualquer registro de que essas aquisições tenham contribuído para o desenvolvimento do ensino superior no Brasil. Ao contrário, conforme os dados do último Censo, há no setor verdadeiro descumprimento às normas e exigências brasileiras por

\footnotetext{
285 Barret, 2003.

${ }^{286}$ Delany, 1996.
} 
diversas universidades. Entre as instituições que não cumprem o determinado, encontra-se a Universidade Estácio de Sá, cotada na bolsa de valores, mas com apenas $23 \%$ dos docentes em tempo integral (menos do que as exigências legais).

Além disso, há preocupações no sentido de que existem ainda vagas ociosas nas instituições de ensino superior privadas (cerca de 37\%, segundo dados do INEP), o que alerta para a possibilidade de total desnacionalização das instituições de ensino superior privadas. Além disso, a baixa transparência na gestão dessas instituições também merece atenção já que a fiscalização, o controle e a regulamentação do setor pelo poder público depende em muito das informações apresentadas pelas próprias instituições de ensino. Essas constatações, por si só, já justificam uma preocupação com o processo de liberalização do setor educacional.

No próximo capítulo, portanto, serão avaliadas as possíveis consequiências que os países enfrentariam se tornassem oficial o compromisso com a liberalização do setor, além de analisar os princípios e as normas do comércio internacional de serviços na OMC e as particularidades dos serviços educacionais para esta organização. 


\section{IV - O COMÉRCIO INTERNACIONAL DE SERVIÇOS EDUCACIONAIS}

Conforme apresentado no capítulo anterior, o reconhecimento da educação como direito humano e como bem público acarreta a necessidade de se tratar o Estado como o principal responsável pela sua promoção e proteção. Assim, o Estado sempre estará obrigado à prestação dos serviços educacionais em todos os seus níveis, a fim de manter os objetivos do direito à educação como propósito central da realização desses serviços. No entanto, a característica do direito à educação como um direito humano econômico, social e cultural, faz com que sua realização dependa de muito mais do que a simples vontade de atuação dos Estados, motivo pelo qual a educação é atualmente oferecida em todos os níveis também pelo setor privado.

Ocorre que, apoiando-se nessa possibilidade de delegar a função pública da prestação de serviços educacionais, os Estados permitiram que a iniciativa privada passasse a representar a maior parte do setor educacional, restando ao Estado o papel indelegável de fiscalizar e regulamentar a prestação dos serviços educacionais. O espaço concedido à iniciativa privada, no entanto, fez que o que o setor movimentasse valores altíssimos, chamando mais ainda a atenção das empresas privadas que passaram a enxergar na educação uma fonte bastante rentável.

O crescimento da iniciativa privada no setor educacional, por sua vez, juntamente com a aceleração do processo de globalização e o desenvolvimento do próprio setor de serviços no plano internacional, atraiu a atenção dos mercados internacionais, que passaram a enxergar na educação, tradicionalmente vista como um serviço público, a possibilidade de tratá-la como mais uma "mercadoria" no comércio internacional.

Já foi visto, porém, que esse tratamento não tem gerado benefícios para a realização do direito à educação como direito humano e bem público. Assim, é necessário olhar com atenção para as negociações internacionais sobre o setor a fim de visualizar seus verdadeiros interesses e as reais vantagens e desvantagens dessa colocação para o direito ao desenvolvimento como objetivo primordial da comunidade internacional.

Para este fim, cumpre, antes de mais nada, analisar o desenvolvimento do comércio internacional de serviços, especificando-se o tratamento dos serviços educacionais nestas negociações, que serão objetos de análise neste capítulo. 


\subsection{O PROCESSO DE REGULAMENTAÇÃO MULTILATERAL DO COMÉRCIO DE SERVIÇOS}

O comércio internacional de serviços não surgiu há pouco, evidentemente. Assim, como o setor de produtos agrícolas e industrializados, o setor terciário já possuía características inter-estatais muito antes de ser objeto de regulamentações internacionais ou regionais. No entanto, nas últimas décadas, o comércio internacional em todos os setores ganhou maior impulso e, conseqüentemente, maior atenção, especialmente devido à criação e à atuação da OMC.

Sabe-se que as negociações internacionais sobre a liberalização do comércio de bens desenvolveram-se muito ao longo da vigência do GATT, assinado em 1947, ocasião em que a intenção de criar uma Organização Internacional do Comércio (OIC) falhou. A proposta de criação da OIC era bastante ambiciosa e previa disposições sobre diversos outros temas além do comércio de bens. Entre esses temas, a Carta de Havana (instrumento constitutivo da OIC) já dispunha sobre a liberalização do comércio de serviços. Conforme já relembrado, a OIC não vingou e o tema de serviços acabou abafado nos anos seguintes de vigência do GATT.

A década de 70, porém, trouxe um novo cenário e abalou as estruturas do comércio internacional tal como previsto no GATT. A economia mundial da época foi marcada por um baixo crescimento econômico, desemprego na Europa, dificuldades na balança de pagamento dos EUA e instabilidade do mercado mobiliário, o que levou os governos dos países desenvolvidos a adotar políticas comerciais mais protecionistas, que, por sua vez, afetava a eficácia do GATT $^{287}$.

Esse protecionismo, marcado principalmente por barreiras não-tarifárias ao comércio como, por exemplo, a concessão de subsídios à produção agrícola interna -, impactava especialmente nos países subdesenvolvidos, cujos produtos de exportação eram os mais prejudicados pelas medidas de proteção dos países desenvolvidos.

Ao mesmo tempo, o tema serviços vincula-se às profundas mudanças operadas nas economias nacionais como resultado da crescente especialização de atividades, associadas à expansão e diversificação dos mercados com reflexos na economia mundial, bem como avanços tecnológicos no setor de bancos, de comunicações, de transmissão eletrônica de dados etc. 
Percebeu-se ainda o importante papel do setor terciário na composição do PIB dos países, sendo que a UNCTAD ${ }^{288}$ constatou que, em 1979, os serviços representavam 64\% do PIB mundial, 67\% do PIB dos países desenvolvidos e 51\% do PIB dos países em desenvolvimento.

A importância dos serviços, portanto, passa a ser estratégica, pois a quantidade e a qualidade dos serviços são fatores determinantes para a definição do nível de desenvolvimento econômico dos Estados. A ausência de serviços educacionais, de saúde, financeiros, de comunicação, entre outros, impede a participação produtiva e efetiva de amplos setores da população na construção de uma economia mais forte ${ }^{289}$.

Diante desse cenário de recessão econômica mundial, medo do protecionismo, incapacidade do sistema multilateral de comércio em lidar com áreas crescentemente relevantes, como serviços e propriedade intelectual, a insatisfação dos EUA com os acordos em vigor, e o crescente déficit na balança de pagamentos dos EUA em relação aos países em desenvolvimento, a idéia de iniciar uma nova rodada de negociações multilaterais pareceu o mais indicado. Nesse sentido, a Rodada Uruguai deve ser entendida antes de tudo como um mecanismo para contornar a crise econômica da década de setenta $^{290}$.

Os preparativos para a Rodada Uruguai levaram quatro anos, de 1982 a 1986. As negociações da rodada duraram sete, de 1986 a 1994, três a mais que o previsto inicialmente, após inúmeras ameaças de fracasso. A idéia de uma nova rodada de negociações surgiu em 1981 e os preparativos iniciaram-se no ano seguinte, em Genebra, na Reunião Ministerial do GATT.

Durante os trabalhos preparatórios da nova rodada, a iniciativa de inclusão do tema “comércio de serviços" nas negociações multilaterais do GATT foi dos EUA. Os países desenvolvidos percebiam as vantagens comparativas que possuíam no setor terciário e acreditavam na inclusão do tema no GATT. A partir de então começava a surgir entre os então países da Organização para a Cooperação e Desenvolvimento Econômico (OCDE) consenso de que a havia necessidade de eliminação das barreiras ao comércio internacional de serviços, especialmente para os japoneses.

\footnotetext{
${ }^{287}$ Cunha, 2005, p.21.

${ }^{288}$ Relatório do Secretariado da UNCTAD, 1985, p. 13.

${ }^{289}$ Mercadante, 1999, p. 414.

${ }^{290}$ Cunha, 2005, p. 23.
} 
Por sua vez, os países em desenvolvimento colocaram-se contra a inclusão dos novos temas, especialmente serviços, no temário do GATT, desde sua proposta inicial, com receio - bastante fundamentado - de que tais assuntos ofuscassem aqueles temas de seu maior interesse. Passaram a adotar uma postura mais ativa nas negociações multilaterais pela inclusão dos temas pendentes nas rodadas anteriores, especialmente o comércio de bens agrícolas e têxteis, nos quais tinham claras vantagens comparativas. A inquietação dos países em desenvolvimento tinha seus motivos: primeiramente, o medo de que os princípios básicos do GATT, que eram aplicados ao comércio de bens, disciplinassem também o comércio de serviços, o que acarretaria em concessões e retaliações cruzadas entre os dois setores. Também tinham ciência de que o setor terciário estadunidense detinha grande parte das vantagens comparativas no mercado internacional e dominaria o setor naturalmente, se não fosse barrado pelas medidas protecionistas dos outros países. Além disso, a forma de liberalização do comércio de bens não fazia sentido se aplicado ao comércio de serviços ainda sem regras e regulamentação internacionais.

A introdução da temática serviços na Rodada Uruguai acabou prevalecendo em virtude da importância do comércio internacional de serviços, apesar da divergência entre países desenvolvidos e em desenvolvimento.

No entanto, concordou-se em não inserir o novo tema no âmbito do GATT, admitindo-se a necessidade de um acordo único para regular o comércio internacional de serviços. Foi estabelecido, portanto, um Grupo de Negociações sobre Serviços, no nível ministerial, juridicamente distinto dos demais grupos negociadores. Além disso, acordou-se que os temas pendentes da rodada anterior, de interesse dos países em desenvolvimento, fossem mantidos e renegociados na Rodada Uruguai.

A inclusão do tema "serviços" nas negociações multilaterais se dá, portanto, a partir da Rodada Uruguai, coma elaboração de um acordo internacional específico para o setor. Ao final da rodada, é criada a OMC, englobando o antigo GATT e o GATS, além de outros acordos.

A elaboração do GATS durou os sete anos da Rodada Uruguai e seus dispositivos foram exaustivamente negociados. Pode-se considerar que a criação do GATS foi uma das maiores conquistas da rodada. Nele, encontram-se os princípios e regras acordadas no 
plano multilateral e juridicamente obrigatórias que regem de modo flexível o comércio internacional de serviços, tendo por finalidade sua liberalização progressiva ${ }^{291}$.

Atualmente o setor de serviços perfaz uma grande e crescente parcela do produto mundial bruto, correspondente a cerca de dois terços. Além disso, o setor terciário tem se situado entre os setores de maior crescimento do comércio mundial nas últimas décadas. A análise do percentual do crescimento anual do setor é baseada nas balanças de pagamentos, o que exclui os serviços prestados no modo 3 do GATS, correspondente ao serviços prestados com presença comercial, que será explicado posteriormente. Isso significa que os números, já elevados, estão ainda subestimados.

Mesmo os países de menor renda têm nos serviços, geralmente, mais de um terço de seu produto interno bruto; nos de renda média, mais da metade; e nos mais ricos, como os Estados Unidos da América (EUA), o percentual sobe para $70 \%$ ou mais.

No Brasil, a percentagem do PIB devida aos serviços foi, em 2001, de 56\%, tendo chegado anteriormente, em 1999, a 65\%. Ainda, o setor de serviços tem recebido cerca de $60 \%$ do total de investimentos estrangeiros diretos que chegam ao Brasil e 92\% dos investimentos brasileiros no exterior ${ }^{292}$.

É evidente, portanto, o crescimento da importância do setor de serviços nas economias de todos os países e, conseqüentemente, não causa espanto que o setor venha se tornando cada vez mais significativo e prioritário nas negociações do sistema multilateral de comércio.

A seguir serão analisadas as peculiaridades do setor de serviços no plano internacional para, em seguida, analisar-se os dispositivos do GATS e, posteriormente aplicá-los às especificidades do setor educacional.

\subsection{AS PARTICULARIDADES DA PRESTAÇÃO INTERNACIONAL DOS SERVIÇOS}

O comércio de serviços possui algumas peculiaridades relevantes que o tornam bastante específico e que justificam um tratamento diferenciado deste setor em comparação ao comércio de bens na OMC.

A primeira dificuldade do setor refere-se à conceituação do termo "serviços". Sob tal denominação agrupam-se inúmeras atividades com pouco em comum. Na verdade, essas diversas atividades muitas vezes apenas se assemelham pelo fato de serem diferentes da

\footnotetext{
${ }^{291}$ Mercadante, 1999, p. 417.

${ }^{292}$ Cunha, 2005, p. 19.
} 
agropecuária, do extrativismo, das empresas de utilidade pública e da indústria. Isso caracteriza o caráter residual dos serviços, que, pode-se dizer, guardam entre si, talvez algumas características como a invisibilidade e a intangibilidade.

Neste sentido, a professora Vera Thorstensen ${ }^{293}$ explica que "bens são tangíveis e visíveis, ao passo que serviços são, na maioria das vezes, intangíveis e invisíveis, além de não poderem ser estocáveis".

Por sua vez, a professora Araminta de Azevedo Mercadante ${ }^{294}$ assinalou que, para os economistas, o conceito de serviços contém duas acepções básicas:

(...) para uns a noção de serviços encontra-se ligada à contribuição dos diferentes fatores ao processo de produção e para outros a ênfase deve ser dada a todos os elementos que permitem distinguir os serviços dos bens materiais. Para a primeira corrente, toda atividade econômica é o resultado do emprego dos fatores de produção; só esses geram o valor agregado e até eles se orienta a corrente de retribuição pela referida criação de riqueza. Nesse sentido, pode-se dizer que o salário é o pagamento pelos serviços do trabalho ou que o lucro representa a remuneração do capital. Para a segunda acepção, o conceito de serviços consiste em destacar a natureza intangível ou invisível da produção de serviços, em contraposição aos bens, tangíveis, móveis e corpóreos. Desse modo, todas as atividades econômicas que geram valor e cujo produto final não seja um objeto material deveriam ser classificados como serviços.

Mercadante afirma ainda que o problema da conceituação dos serviços vai mais além e polemiza o próprio conceito do comércio internacional de serviços, já que torna muito tênue a diferenciação entre o comércio de serviços e o investimento internacional no setor de serviços. Isso porque os fluxos internacionais de serviços estão predominantemente associados a fluxos de investimento, pois o investimento direto no exterior pode ser uma condição necessária para o comércio internacional de serviços ${ }^{295}$.

Dominique Carreau e Patrick Juillard ${ }^{296}$, por sua vez, entendem o comércio internacional de serviços como uma operação complexa, que, ao contrário do comércio de bens, não é autônoma, sendo que a livre prestação dos serviços depende necessariamente da presença concomitante de outras liberdades econômicas. Assim, o fornecimento de serviços deve ser analisado em atenção a um conjunto de operações complementares relevantes de diversos setores, como a mobilidade e o estabelecimento de pessoas, os investimentos estrangeiros, a conversão monetária etc, os quais buscam o mesmo fim: oferecer e garantir um serviço a

\footnotetext{
293 Thorstensen, 2003, p. 195.

294 Mercadante, 1999, p. 418.

${ }^{295}$ Mercadante, 1999, p. 419. Por fim, conceitua o comércio internacional de serviços como "o conjunto de atividades econômicas em que há movimento transfronteira de invisíveis ou de pessoas que os executam, sem envolver mercadorias. Abrange, pois, o movimento de serviços, de consumidores e de fatores de produção através das fronteiras, quando tal movimento for essencial aos fornecedores e consumidores".
} 
um público estrangeiro determinado. Isso significa, portanto, que a concretização do comércio internacional de serviços está diretamente ligada à livre circulação de pessoas, à liberdade dos pagamentos internacional e à liberdade de investimentos.

Além do problema da conceituação, outra dificuldade enfrentada pelo comércio internacional de serviços é o fato de que as barreiras ao comércio não são tarifárias, o que torna mais difícil a sua identificação e transposição. De fato, as barreiras de acesso a prestadores de serviços derivam de normas jurídicas, como leis, regulamentos, atos administrativos, etc., que impedem o fluxo comercial de serviços internacional. É de se imaginar que essas características das barreiras ao comércio de serviços dificultam o andamento das negociações multilaterais no setor, vez que são de difícil identificação, o que torna as negociações menos transparentes.

Assim, liberalizar na área de serviços não é uma questão de reduzir ou eliminar tarifas. Ao contrário, na maior parte dos casos, se relaciona com direitos de cidadania, valores culturais, histórias de povos, e outros elementos mais profundos e complexos para a totalidade dos países envolvidos nessa negociação ${ }^{297}$. Isso significa que as negociações no setor de serviços são muito mais delicadas do que as negociações sobre bens.

Thorstensen indica ainda outra peculiaridade do setor de serviços que é a grande lacuna de dados estatísticos, assim como a falta de uma metodologia que possa tornar os dados comparáveis $^{298}$. Dessa forma, o estudo sobre os números exatos do setor torna-se bastante impreciso.

Essa lacuna de dados tem se tornado ainda maior com o advento de serviços virtuais, ou seja, prestados por meio da Internet, como é o caso dos serviços de e-learning, já introduzidos no capítulo anterior.

\subsection{O ACORDO GERAL SOBRE COMÉRCIO DE SERVIÇOS (GATS)}

O GATS faz parte do quadro jurídico da OMC e é administrado pelo Conselho para o Comércio de Serviços, que, por sua vez, está vinculado ao Conselho Geral da OMC.

O Acordo foi negociado em quatro partes distintas. A primeira estabelece um quadro de regras para regulamentar o setor de serviços, contendo princípios gerais e obrigações a todos os Estados parte, além de conceitos gerais aplicados ao comércio do setor. A segunda, por sua vez, é composta dos anexos que determinam princípios e regras para

\footnotetext{
${ }^{296}$ Carreau e Juillard, 1998, p. 316-317.
}

${ }^{297}$ Rebrip, 2006, p. 13 
setores específicos. São quatro anexos: (i) sobre movimento de pessoas físicas; (ii) sobre serviços financeiros; (iii) sobre telecomunicações; e (iv) sobre serviços de transporte aéreo. A terceira parte contém os compromissos de liberalização assumidos por cada membro do Acordo para cada setor, sejam eles compromissos de acesso a mercado ou de tratamento nacional nas áreas de comércio e investimento ${ }^{299}$. Esta terceira parte do Acordo é que contém, portanto, as chamadas listas nacionais de cada Membro (listas com os compromissos assumidos em cada setor). Por fim, a quarta sessão do Acordo contém as chamadas listas de exceção ao princípio da cláusula da nação mais favorecida, que proíbe a discriminação entre os países. Estas listas indicam quais os setores em que os membros não precisam temporariamente aplicar este princípio $^{300}$.

Ressalte-se, portanto, que a negociação no setor de serviços ocorre de uma forma fundamentalmente distinta do comércio de bens. Enquanto no setor de bens são negociadas regras gerais que se aplicam a todos os segmentos, no setor de serviços, a liberalização se dá de forma progressiva, por meio de listas positivas, que indicam exata e especificamente os compromissos assumidos ${ }^{301}$.

Por estes motivos, as negociações comerciais sobre serviços não podem ser tratadas da mesma forma que o comércio de bens, de acordo com as regras e princípios GATT.

O GATS é composto de 29 artigos aplicáveis a todos os setores de serviços, o correspondente à metade da extensão do GATT. Seus artigos são divididos em seis partes. Nesse sentido, Karla Cristina Martins Borges ${ }^{302}$ explica que:

Na parte I do GATS são apresentados seu escopo e definição, assim como os critérios que norteiam a liberalização comercial. Nesta parte são categorizadas as quatro modalidades de prestação dos serviços no comércio internacional (...). A Parte II trata das obrigações gerais e disciplinas, como os princípios (...). As Partes III e IV tratam dos compromissos específicos e do sistema para a liberalização progressiva (...). A Parte $\mathrm{V}$ traz provisões quanto à estrutura institucional referente a consultas e solução de constrovérsias, ao conselho do comércio de serviços, cooperação técnica e, por fim, a Parte VI apresenta as definições dos termos do GATS.

O preâmbulo do Acordo destaca os objetivos do GATS por meio de três considerações principais:

\footnotetext{
298 Thorstensen, 2003, p. 195.

${ }^{299}$ A seguir serão explicados os termos aqui empregados.

300 Thorstensen, 2003, p. 196.

301 As negociações do comércio de bens são conhecidas como de "cima para baixo" (top down), enquanto no setor de serviços, as negociações são chamadas de "baixo para cima" (bottom up).

302 Borges, 2008, p. 22-23.
} 
(i) o acordo multilateral de princípios e regras para a abertura progressiva do comércio de serviços deve proporcionar a expansão mundial do desenvolvimento econômico;

(ii) todos os Membros da OMC, e em particular os países em desenvolvimento, deverão exercer uma regulação do comércio de serviços tendo em vista suas políticas nacionais; e

(iii) os países em desenvolvimento devem ser auxiliados para que tenham uma maior participação no mercado de prestação de serviços. A promoção do crescimento econômico e o desenvolvimento dos países de menor desenvolvimento relativo terão como base a transparência e a liberalização progressiva ${ }^{303}$.

O Acordo reconhece ainda que a liberalização do setor de serviços deverá ser realizada através de sucessivas rodadas multilaterais de negociação, visando promover os interesses de todos os participantes de forma mutuamente vantajosa, assegurando um equilíbrio entre direitos e obrigações, com especial atenção para que se mantenha espaço para a formulação e realização das políticas públicas nacionais ${ }^{304}$.

$\mathrm{Na}$ verdade, como bem afirma Gustavo Ribeiro ${ }^{305}$, quando o GATS foi instituído, ainda não estava claro de que forma este conjunto de regras, à regular o comércio internacional de serviços, iria operar e nem quais setores seriam abrangidos pelo acordo. Em 1999, porém, o Secretariado da OMC adotou uma lista ${ }^{306}$ de 12 grandes setores de serviços, divididos em 155 subsetores, que estariam sujeitos às regras do GATS.

Assim, estão sob a regulamentação do GATS os seguintes setores: (i) serviços profissionais e de consultoria (médico, jurídico, engenharia, contábil, pesquisa e desenvolvimento, computação, imobiliário, propaganda e vendas; (ii) serviços de comunicação; (iii) serviços de construção e de engenharia; (iv) serviços de distribuição; (v) serviços educacionais; (vi) serviços ambientais; (vii) serviços financeiros e de seguros; (viii) serviços de turismo e viagens; (ix) serviços de saúde; (x) serviços de recreação, cultural e de esporte; (xi) serviços de transporte; e (xii) serviços gerais (outros serviços, de cunho genérico).

\subsubsection{Os modos de prestação dos serviços}

O Artigo I do GATS define o comércio de serviços em quatro modos de prestação dos serviços, quais sejam: (i) do território de um Membro ao território de qualquer outro Membro (Modo 1); (ii) no território de um Membro aos consumidores de serviços de qualquer outro Membro (Modo 2); (iii) pelo prestador de serviços de um Membro, por

\footnotetext{
${ }^{303}$ Pupo, 2005, p. 44.

${ }^{304}$ Artigo XIX, parágrafos 1e 2.

${ }^{305}$ Ribeiro, 2006, p. 5.

${ }^{306}$ A lista de setores e subsetores do GATS foi elaborada com base na Central Product Classification (CPC), sistema de classificações mantido pela Divisão de Estatística das Nações Unidas (GNS/W/120).
} 
intermédio da presença comercial, no território de qualquer outro Membro (Modo 3); e (iv) pelo prestador de serviços de um Membro, por intermédio da presença de pessoas naturais de um Membro no território de qualquer outro Membro (Modo 4).

O Modo 1 também chamado de prestação transfronteiriça de serviços (cross-border supply) consiste na situação em que somente o produto ou serviço cruza a fronteira do país para ser utilizado por um consumidor em outro Estado. Inexiste, nesta modalidade, a transposição de qualquer profissional prestador do serviço. É o caso dos serviços de telecomunicações, de projetos de engenharia, mercadorias enviadas para reparo ou processamento, contratação de pareceres jurídicos, entre outros. É o caso também da educação à distância, em que o aluno em um país recebe o serviço educacional advindo de uma instituição em outro país.

O Modo 2 é composto pelos serviços consumidos no exterior (consumption abroad), envolvendo o deslocamento do consumidor de serviços de um país para outro, onde está localizado o prestador dos serviços que o primeiro deseja consumir. Como exemplo, cite-se os serviços de turismo, tipicamente consumidos no exterior. Também os setores de serviços educacionais e médicos são freqüentemente realizados nesta modalidade de prestação. No caso dos educacionais, fala-se em consumo no exterior para as situações em que os alunos se deslocam para estudar em instituições de ensino situadas em países estrangeiros.

O Modo 3, por sua vez, baseia-se na presença comercial (commercial presence) do prestador de serviços, "nacional" de um país, no território de um outro país, por meio da abertura de uma filial. É a modalidade mais demandada pelos países em desenvolvimento, cujas empresas prestadoras de serviços desejam expandir sua atuação para outras regiões do mundo. No entanto, esta modalidade possui as barreiras ao comércio mais difíceis de se transpor, já que se referem à regulamentação interna sobre o estabelecimento de empresas estrangeiras no território nacional. Assim, a abertura de filiais e agências de bancos estrangeiros é um bom exemplo da prestação de serviços pelo Modo 3.

Para os países em desenvolvimento, a modalidade da presença comercial pode ser interessante, pois atrai investimentos estrangeiros e fomenta a circulação econômica dentro do país. No entanto, outros efeitos - nem um pouco positivos - podem surgir, como a desnacionalização do setor, já que a presença de empresas estrangeiras fortes em determinado setor poderá desbancar de forma avassaladora as prestadoras de serviços nacionais. Além disso, muitas vezes o lucro obtido com o estabelecimento da empresa no 
país não é reinvestido no país, mas enviado ao país de origem da empresa. Por este motivo, a regulamentação interna sobre este modo de prestação de serviços é bastante importante, a fim de assegurar os seus benefícios, como a atração dos investimentos de forma regular, a transferência de tecnologia e know-how etc.

No caso dos serviços educacionais, o Modo 3 pode ser visualizado quando o provedor da educação se estabelece comercialmente em outro país para prestar seus serviços em uma sede local ou em campus-satélite, instituições gêmeas ou ainda, acordos de franquias com instituições locais.

Por fim, o Modo 4, também conhecido como presença de pessoas físicas (presence of natural persons), refere-se à admissão de estrangeiros que venham prestar seus serviços pessoalmente no território diverso do de sua nacionalidade. É o caso mais comuns na prestação de serviços por músicos, consultores, jogadores, entre outros.

Esta modalidade é bastante demandada pelos países em desenvolvimento, mas enfrenta sérias restrições dos países desenvolvidos, que costumam fechar seus mercados de trabalho aos estrangeiros. De qualquer forma, ainda que venham a assumir compromissos nesta modalidade de prestação, os países podem ainda determinar regras e exigências para a entrada e a permanência dos prestadores de serviços estrangeiros em seus territórios.

No caso dos serviços educacionais, enquadram-se no Modo 4, os profissionais que viajam para outros países diversos do de sua nacionalidade para prestar seus serviços, como professores e pesquisadores.

Ressalte-se que os setores de serviços previstos no GATS poderão ser prestados em mais de uma das modalidades acima, como é o caso dos serviços educacionais. Os compromissos que cada Estado assume no âmbito da OMC referem-se especificamente a cada um dessas modalidades, sendo que um país poderá se comprometer a abrir o mercado de serviços educacionais para o Modo 3, mas não para o Modo 4, por exemplo.

\subsubsection{Princípios e obrigações do comércio de serviços}

As principais regras e obrigações previstas no GATS são a aplicação efetiva de alguns princípios do comércio internacional. Alguns desses princípios já estavam previstos pelo GATT anteriormente e outros são específicos do comércio de serviços.

Pode-se dizer que, da análise dos artigos da segunda parte do GATS, tem-se que os Estados deverão atender às seguintes determinações pela liberalização do setor de serviços: 
a) Cláusula da nação mais favorecida

O princípio da cláusula da nação mais favorecida é também como base a impossibilidade de discriminação entre os países e é conhecido como a regra geral básica do GATS e da OMC como um todo, ou seja, é um princípio também previsto do GATT.

Assim, de acordo com o artigo II do GATS, todos os países Membros da OMC estão obrigados a conceder, imediata e incondicionalmente, aos serviços e prestadores de serviços de qualquer outro Membro tratamento igual, não menos favorável do que aquele concedido a serviços e prestadores de serviços similares de qualquer outro país.

Isso significa que qualquer benefício em termos de liberalização do comércio de serviços concedido aos serviços e prestadores de serviços de um determinado país, ainda que este não seja Membro da OMC, deverá ser imediatamente concedido a todos os demais países signatários do GATS.

Apesar de ser a regra fundamental, que sustenta a política toda da $\mathrm{OMC}$, o parágrafo 2, do artigo II permite que um país mantenha uma medida incompatível com o princípio da cláusula da nação mais favorecida, desde que ela esteja lista no Anexo II ao GATS (lista de exceções à cláusula da nação mais favorecida) e que satisfaça as determinações definidas na lista. Trata-se, porém, de uma exclusão temporária, que deverá gradativamente ser eliminada de forma a buscar o pleno cumprimento deste princípio geral.

Ainda, deve-se ressaltar que este artigo não se aplica às medidas tomadas pelos países que concedam vantagens aos serviços consumidos e produzidos em Estados limítrofes, a fim de facilitar o comércio em zonas de fronteira contígua. Esta exceção relaciona-se com a regra do GATS específica para o processo de integração regional, que será estudado abaixo.

b) Transparência

Prevista no artigo III do GATS, esta regra determina que todas as medidas adotadas por algum Membro que, de alguma forma, possam influenciar as relações de comércio reguladas pelo Acordo, deverão tornar-se público prontamente. Assim, a celebração de acordos internacionais fora do âmbito da OMC, a aprovação de novas legislações, regulamentos ou normas administrativas referentes ao comércio de serviços ou que tratem de requisitos gerais sobre a prestação dos serviços previstos no GATS no território nacional, bem como qualquer alteração feita às regras internas já existentes, deverão ser informadas ao Conselho sobre o Comércio de Serviços. 
Além disso, os países deverão manter centros direcionados a fornecer informações sobre essas matérias aos demais Membros. O verdadeiro objetivo desta obrigação é dar transparência às medidas que influenciam o funcionamento do GATS ${ }^{307}$.

c) Participação de países em desenvolvimento

As provisões do artigo IV, por sua vez, buscam uma maior participação ativa dos países em desenvolvimento ou de menor desenvolvimento relativo. Assim, dispõe sobre a necessidade celebração de compromissos específicos para: (i) o fortalecimento da capacidade desses países no comércio de serviços, sua eficiência e competitividade, por exemplo, por meio de acesso à tecnologia de base comercial; (ii) melhoria no acesso aos canais de distribuição e redes de informação; e (iii) a liberalização de acesso a mercados de setores e modos de prestação de interesse dos países em desenvolvimento, levando em consideração suas exportações.

d) Integração econômica

$\mathrm{O}$ artigo $\mathrm{V}$ do GATS permite que os Membros celebrem acordo regionais em matéria de liberalização do comércio de serviços, desde que referidos acordos tenham cobertura setorial substancial, ou seja, abranjam considerável número de setores, volume de comércio e modos de prestação de serviços, além de preverem a eliminação em termos substanciais de todo tipo de discriminação entre as partes do acordo regional celebrado nos setores cobertos.

O GATS ressalva, porém, que o acordo regional deve facilitar o comércio entre as parte, mas não deve aumentar o nível geral de barreiras ao comércio de serviços para Membros da OMC que não sejam partes do acordo, comparativamente à situação anterior à sua celebração.

Além dessas disposições, o artigo V bis, do GATS, prevê que os Membros também poderão celebrar acordos regionais para promover a integração de seus mercados de trabalho $^{308}$, desde que o acordo em questão seja notificado ao Conselho sobre o Comércio de Serviços da OMC e isente os cidadãos dos seus Estados partes quanto à obtenção dos vistos de residência e de trabalho.

e) Regulamentação doméstica

\footnotetext{
${ }^{307}$ Pupo, 2005, p. 52.

${ }^{308}$ Essa integração dos mercados de trabalho, em geral, proporciona aos cidadãos das partes envolvidas um direito de livre admissão nos mercados de trabalho das partes e inclui a concessão de benefícios sociais e determinações sobre as condições de pagamento dos trabalhadores.
} 
No que tange à regulamentação interna dos Estados Membros, o GATS determina que, nos setores, em que forem assumidos compromissos específicos, os países cuidem para que as suas regras e medidas de aplicação interna que afetem o comércio de serviços de alguma forma, sejam administradas de forma razoável, objetiva e imparcial (artigo VI).

Isso porque os procedimentos e normas técnicas, os requisitos de qualificação e de licenciamento, adotadas por um Membros nos setores em que este tenha assumido compromissos específicos, não poderão constituir forma de barreira, restrição ou distorção do comércio de serviços. "A intenção é evitar que esses procedimentos e normas, embora devidamente justificáveis e necessários, não disfarcem algum tipo de barreira de fato à entrada ou permanência da prestação de serviços em setores que o Membro se comprometa formalmente a liberalizar, ${ }^{, 309}$.

Lembre-se que, pelo princípio da transparência, todas essas medidas que regulamentam a prestação dos serviços abrangidos pelo GATS deverão ser apresentadas ou notificadas ao Conselho sobre o Comércio de Serviços.

f) Reconhecimento

$\mathrm{O}$ artigo VII do GATS diz respeito às normas e critérios para autorização, licença ou certificação de prestadores de serviços. Neste sentido, referido dispositivo prevê que, para cumprir com as exigências de padrões e critérios internos, um país Membro poderá reconhecer a formação e a experiência obtidas ou as licenças e certificações concedidas por outro determinado país.

Esse reconhecimento, em geral, se dar por meio: (i) da harmonização das normas, exigências e critérios nas legislações internas dos países interessados no reconhecimento mútuo; ou (ii) de acordo ou convenio entre os países.

Ressalte-se que, conforme determinado pelo GATS, este reconhecimento não poderá ocasionar qualquer tipo de discriminação entre os Membros do Acordo e deverá conceder oportunidades para que os demais Membros possam também aderir aos acordos, convênios ou políticas de harmonização.

Neste caso, ao contrário do que ocorre com os acordos de integração econômica, o GATS exige a possibilidade de extensão dos benefícios relativos ao reconhecimento aos demais países Membros da OMC que queiram se adequar às exigências internas.

g) Monopólios e os prestadores exclusivos 
O GATS exige que cada Membro assegure que cada prestador que goze de monopólio ${ }^{310}$ sobre determinado serviço em seu território não aja de maneira incompatível com as obrigações daquele Estado (artigo VIII).

Além disso, o artigo IX repreende quaisquer práticas de prestadores de serviços que possam limitar a concorrência no setor e, dessa forma, restringir o comércio de serviços.

h) Medidas de salvaguarda de emergência

O GATS não disciplina a questão das medidas de salvaguarda, mas dispões em seu artigo $\mathrm{X}$, que os Membros deveriam negociar sobre a sua aplicação de forma que os resultados dessas negociações produzissem efeitos no mais tardar, após três anos da data de entrada em vigor do Acordo Constitutivo da $\mathrm{OMC}^{311}$, ou seja, até 2002. A única exigência feita pelo GATS é que a aplicação dessas medidas esteja de acordo com o princípio da nãodiscriminação.

No entanto, o prazo estabelecido pelo GATS tem sido continuamente prorrogado, sendo que até o momento, mais de dez anos após o início da vigência do Acordo Constitutivo da OMC, não existe qualquer entendimento geral sobre a aplicação das medidas de salvaguarda emergenciais para o comércio de serviços, que continuam gerando controvérsias entre países desenvolvidos, em desenvolvimento e de menor desenvolvimento relativo ${ }^{312}$.

Ressalte-se apenas que as medidas de salvaguarda têm por objetivo "aumentar, temporariamente, a proteção a um prestador de serviços doméstico que esteja sofrendo prejuízo grave ou ameaça de prejuízo grave decorrente da prestação de serviços estrangeiros". Assim, durante o período de vigência dessas medidas, a indústria doméstica pode se ajustar, aumentando sua competitividade ${ }^{313}$.

i) Pagamentos e transferências

\footnotetext{
${ }^{309}$ Pupo, 2005, p. 55.

${ }^{310}$ O artigo XXVIII, alínea "h", do GATS, define o conceito de prestador de serviços monopolista como qualquer pessoa pública ou privada que, no correspondente mercado do território de um Membro, tenha sido autorizada ou tenha se estabelecido, legalmente ou de fato, por aquele Membro, como único prestador daquele serviço.

311 O Acordo Constitutivo da OMC contém regras e princípios gerais aplicáveis ao comércio internacional em geral e dispõe sobre a forma das negociações, a estrutura, a administração, regras para acessão de novos Membros, entre outros temas globais e relativos ao seu funcionamento prático. Os acordos específicos, como o GATS, são incorporados ao Acordo Constitutivo como seus anexos. Todos os países Membros da OMC, portanto, são também partes no GATS. O GATT 1947 também foi incorporado ao sistema de norma da OMC.

312 Borges, 2008, p. 146. Neste artigo é possível encontrar maiores informações sobre as negociações envolvendo as medidas de salvaguarda emergenciais e sua relação com este mecanismo no âmbito do GATT.
} 
$\mathrm{O}$ artigo XI do GATS determina que os Membros não poderão aplicar restrições sobre os pagamentos e transferências internacionais de transações correntes relacionadas aos compromissos específicos.

Por sua vez, o artigo XII estabelece exceções à estas proibições, que se referem aos casos de sérias dificuldades financeiras externas, de balança de pagamentos, ou por solicitação do FMI, pois reconhece que em processos de desenvolvimento e em economias de transição, um Membro poda precisar impor restrições para assegurar a manutenção do nível de suas reservas financeiras. Mas, estas medidas devem evitar danos desnecessários aos interesses comerciais, econômicos e financeiros de outro Membro, nem devem exceder o necessário para resolver a circunstancia e devem ser temporárias.

\section{j) Compras governamentais}

$\mathrm{O}$ artigo XIII determina que as compras governamentais no tocante ao comércio de serviços, entendidas como as contratações de serviços realizadas pelo governo para fins de uso público e oficial e não destinados à revenda, não se sujeitam ao princípio da cláusula da nação mais favorecida, acesso a mercados ou tratamento nacional, ou seja, estão fora dos compromissos assumidos no GATS.

\section{k) Exceções gerais}

A primeira parte do GATS, contendo os princípios e obrigações aos Membros, ainda traz algumas exceções gerais, que poderão ser adotadas pelos Membros, desde que não constituam mecanismo de discriminação arbitrária entre os países com condições similares ou, na verdade, mascarem uma verdadeira restrição ao comércio.

Assim, os países poderão adotar medidas que não estejam de acordo com todas as regras do GATS, apenas nas seguintes condições: (i) quando forem necessárias para proteger os bons costumes ou para manter a ordem pública; (ii) quando necessárias para a proteção da vida e da saúde das pessoas e animais e para a preservação do meio ambiente; (iii) quando necessárias para garantir a observância das disposições legislativas e regulamentares que não sejam incompatíveis com o disposto no Acordo, como, por exemplo, medidas de prevenção de práticas dolosas ou fraudulentas, proteção da privacidade dos indivíduos em relação ao processamento e disseminação de dados pessoas; (iv) quando forem medidas incompatíveis com o tratamento nacional, desde que com o objetivo de cobrar impostos em relação a serviços ou prestadores de serviços de outros Membros; (v) quando forem 
medidas incompatíveis com a cláusula da nação mais favorecida, desde que a diferença de tratamento resulte de acordos internacionais para evitar a bitributação (artigo XIV).

O GATS ainda prevê exceções no sentido de não exigir que os países adotem medidas contrárias aos seus interesses de segurança nacional ou incompatíveis com a Carta das Nações Unidas (artigo XIV bis).

1) Subsídios

Por fim, a primeira parte do GATS traz dispositivos sobre a possibilidade de concessão de subsídios que, no setor de serviços, possuem as seguintes características básicas:

(i) contribuição financeira de um governo ou órgão público dentro do território de um Membro;

(ii) o benefício, ou vantagem conferida ao prestador, deve ser efetivamente conferido em condições mais vantajosas que a prática comercial do mercado; e, por fim,

(iii) o subsídio deve ser acionável ou proibido ${ }^{314}$ e específico ${ }^{315}$.

$\mathrm{O}$ artigo XV do GATS reconhece que os subsídios no setor de serviços poderão causar distorções ao comércio e, portanto, ressaltam a importância de se realizarem negociações entre os Membros para elaborar as disciplinas multilaterais necessárias para evitá-las, levando sempre em consideração que, em alguns casos, os subsídios podem servir como mecanismo de promoção do desenvolvimento de países em desenvolvimento e de menor desenvolvimento relativo.

\subsubsection{Compromissos específicos}

A segunda parte do Acordo GATS, conforme já mencionado anteriormente, é composta pelas regras sobre os compromissos específicos, correspondentes aos artigos XVI ao XVIII. Assim, estes dispositivos determinam de que forma os países devem assumir seus compromissos específicos.

O GATS prevê, portanto, que os países deverão assumir compromissos de liberalização no setor de serviços quando ao acesso ao mercado e quanto ao tratamento nacional. Isso significa dizer que, quando um Membro se compromete e abrir um setor específico de serviços na OMC, permitirá que os serviços e prestadores de serviços neste setor dos demais Membros ingresse no seu mercado interno, na forma como se comprometeu, além de conferir-lhes tratamento não menos favorável ao concedido aos serviços ou prestadores de serviços similares nacionais.

${ }^{314}$ Respectivamente conhecidos também por subsídios amarelos e vermelhos. Os subsídios verdes são os não acionáveis, pois não prejudicam e nem ameaçam a indústria doméstica. 
Ressalte-se que os países poderão determinar compromissos quantos às obrigações de acesso a mercado e tratamento nacional para cada setor especificamente (compromissos por setor), bem como para o setor de serviços como um todo (compromissos horizontais), em cada um dos modos de prestação de serviços.

Ao assumirem compromissos em relação a acesso a mercados, os Membros já deverão fazer constar de suas listas de compromissos as exceções, limitações e condições que pretendam impor, não podendo fazê-lo posteriormente, quando, então, não poderão adotar medidas definidas como:

(i) limitações sobre o número de prestadores de serviços, seja em forma de quotas, monopólios, exclusividade ou exigências de testes de necessidades econômicas; (ii) limitações sobre o valor total das transações de serviços ou ativos em forma de quotas numéricas ou exigências de necessidade econômica; (iii) limitações sobre o número total de operações de serviço, ou na quantidade total do fornecimento do serviço, expresso em termos de unidades numéricas; (iv) limitações sobre o número total de pessoas físicas que possam ser empregadas em um setor de serviço particular, ou que um prestador possa empregas e que seja necessário para a prestação do serviço; (v) medidas que restrinjam ou exijam um tipo específico de pessoa jurídica ou joint venture, através do qual um prestador de serviço possa prestar seu serviço; (vi) limitações sobre a participação de capital estrangeiro, em termos de máxima porcentagem ou participação acionária, ou sobre o valor total do investimento estrangeiro individual ou agregado ${ }^{316}$.

Ao contrário dos compromissos em acesso a mercados, o GATS não traz nenhum exemplo de medidas que poderão ser enquadradas como violações a este princípio. Os Estados que assumirem compromissos sobre determinado setor de serviços estarão sujeitos automaticamente à disciplina do tratamento nacional (artigo XVII). Poderão, no entanto, estabelecer em suas listas nacionais as exceções, limitações ou condições a esta obrigação.

Por fim, caso entendam necessário, os países poderão fazer constar de suas listas de compromissos, a sua decisão de assumir compromissos adicionais, diferentes das obrigações de acesso a mercados e tratamento nacional (artigo XVIII). Se, por exemplo, um país quiser assumir o compromisso de reduzir ou eliminar a exigência de qualificações específicas para um determinado setor de serviços, este será um compromisso adicional.

Os compromissos adicionais, por óbvio, não são obrigatórios.

4.3.3.1. Como analisar as listas nacionais?

${ }^{315}$ Pupo, 2005, p. 61.

316 Thorstensen, 2003, p. 202-203, sobre o artigo XVI. 
Em atenção às regras estabelecidas nesta terceira parte do GATS, as listas nacionais, contendo os compromissos específicos assumidos pelos Membros da OMC possuem a seguinte estrutura:

\begin{tabular}{|c|c|c|c|}
\hline \multicolumn{4}{|c|}{ Compromissos Horizontais } \\
\hline $\begin{array}{l}\text { Setores ou } \\
\text { Subsetores }\end{array}$ & $\begin{array}{c}\text { Art. XVI (Acesso a } \\
\text { Mercados) }\end{array}$ & $\begin{array}{c}\text { Art. XVII (Tratamento } \\
\text { Nacional) }\end{array}$ & $\begin{array}{c}\text { Compromissos } \\
\text { Adicionais }\end{array}$ \\
\hline \multirow{4}{*}{ Todos os setores } & Modo 1 & Modo 1 & Modo 1 \\
\hline & Modo 2 & Modo 2 & Modo 2 \\
\hline & Modo 3 & Modo 3 & Modo 3 \\
\hline & Modo 4 & Modo 4 & Modo 4 \\
\hline \multicolumn{4}{|c|}{ Compromissos por Setor } \\
\hline $\begin{array}{l}\text { Setores ou } \\
\text { Subsetores }\end{array}$ & $\begin{array}{c}\text { Art. XVI (Acesso a } \\
\text { Mercados) }\end{array}$ & $\begin{array}{c}\text { Art. XVII (Tratamento } \\
\text { Nacional) }\end{array}$ & $\begin{array}{c}\text { Compromissos } \\
\text { Adicionais }\end{array}$ \\
\hline \multirow{4}{*}{$\left(\mathrm{CPC} \mathrm{n}^{\mathrm{o}} \ldots\right)$} & Modo 1 & Modo 1 & Modo 1 \\
\hline & Modo 2 & Modo 2 & Modo 2 \\
\hline & Modo 3 & Modo 3 & Modo 3 \\
\hline & Modo 4 & Modo 4 & Modo 4 \\
\hline
\end{tabular}

Assim, os compromissos assumidos pelos Estados no GATS serão sempre divididos por modo de prestação de serviços em cada um dos tipos de compromissos assumidos.

Para a determinação do alcance do compromisso assumido pelo país Membro em cada setor, subsetor, por coluna (acesso a mercado, tratamento nacional e compromissos adicionais) e por modo de prestação de serviços, é utilizada uma terminologia própria do GATS, com as expressões: “none” (nenhuma) e "unbound” (não consolidado).

O termo "none" é utilizado quando um país assume compromissos, indicando a ausência de restrições ou limitações. Quando estiver inserido na lista de compromissos horizontais (seja em acesso a mercados ou tratamento nacional), significa que não existem quaisquer restrições ou limitações quanto à prestação de serviços em geral. No entanto, se previsto em um setor ou subsetor específico, a ausência de restrições para acesso ao mercado e 
tratamento nacional neste setor está condicionada aos compromissos assumidos na tabela de compromissos horizontais.

Por sua vez, o termo "unbound" ${ }^{317}$ deverá aparecer quando inexistir qualquer compromisso daquele país - seja no tocante ao setor de serviços como um todo, seja por setor ou subsetor determinado, por modo de prestação de serviço e em relação a cada uma das obrigações: acesso a mercado e tratamento nacional. Assim, quando um Estado Membro deseja manter restrições quanto ao acesso ao mercado ou tratamento nacional de um determinado serviço, em um ou mais modos de prestação de serviços, diz-se que ele não está consolidado (unbound).

Ressalte-se, porém, que para verificar o verdadeiro grau de abertura comercial no setor de serviços de um determinado país, é necessário consultar, além de sua lista nacional, contendo os compromissos por ele assumidos, a lista de exceções ao princípio da cláusula da nação mais favorecida ${ }^{318}$.

\subsubsection{Liberalização progressiva}

A quarta parte do GATS refere-se à prática de liberalização no setor de $\operatorname{serviços~}^{319}$. De acordo com as disposições do Acordo, a liberalização do comércio de serviços deve ser entendida como um processo.

Assim, as negociações deverão ocorrer em rodadas sucessivas para aumentar progressivamente os compromissos de liberalização do setor de serviços. Isso porque o processo de liberalização deve atentar para os objetivos de política nacional e para os níveis de desenvolvimento dos Estados Membros, devendo haver flexibilidade apropriada para os países em desenvolvimento.

O processo de liberalização pode avançar em cada rodada de negociação, ou por maio de negociações bilaterais, plurilaterais ou multilaterais, em direção ao aumento do nível geral de compromissos assumidos pelos Membros.

A liberalização progressiva do setor de serviços se dá, portanto, por meio da expansão dos compromissos assumidos pelos países em suas listas nacionais positivas, lembrando-se que

317 O termo "unbound" poderá ser utilizado ainda quando o comércio de um setor ou subsetor de serviços específico em determinados modos de prestação não é realizável, pois impossível, como a prestação de serviços de construção de edifícios no modo de prestação transfronteiriça.

${ }^{318}$ A lista de isenções à cláusula da nação mais favorecida está prevista em um anexo ao GATS, que permite que os países listem algumas medidas entendidas como incompatíveis com a cláusula da nação mais favorecida temporariamente. As isenções deverão ser revistas de cinco em cinco anos e devem ter duração máxima de 10 anos.

${ }^{319}$ Pupo, 2005, 64. 
estas listas indicam que apenas o que está contido nelas é negociável, sendo que da ausência de determinações sobre um setor de serviços, subentende-se que o país não assumiu qualquer compromisso neste assunto.

\subsection{AS NEGOCIAÇÕES DE SERVIÇOS E A RODADA DOHA}

Em razão da determinação do artigo XIX do GATS, que dispõe que os Membros da OMC se comprometem a recolocar as negociações sobre o comércio de serviços no prazo máximo de cinco anos depois da entrada em vigor do Acordo, ao longo do ano de 1999, os diversos Membros do GATS enviaram suas propostas para discussão. A análise dessas propostas torna claro que, ainda que a maioria dos países esteja de acordo com a liberalização progressiva e a gradativa ampliação dos setores, os Membros divergem no modo pelo qual essa liberalização deve ser efetuada, contrapondo países em desenvolvimento aos países desenvolvidos, cada qual priorizando seus interesses próprios $^{320}$.

Entre os destaques das propostas, ressalte-se o entendimento de diversos países sobre a necessidade de melhor conceituação e delimitação do conceito de serviços e dos setores e subsetores previstos no GATS. Além disso, destacam-se as diversas referências à necessidade de maior atenção à condição dos países em desenvolvimento, que deverão ter tratamento diferenciado no atendimento às regras do comércio internacional de serviços.

Além disso, vale ressaltar a sugestão de alguns países desenvolvidos quanto à necessidade de se promover o estabelecimento de compromissos horizontais, que envolvam, portanto, todos os setores e subsetores de serviços de uma única vez.

Por outro lado, é bastante forte o posicionamento dos países em desenvolvimento em relação à necessidade de avanços significativos no comércio de bens agrícolas e não agrícolas, antes de se falar na liberalização do comércio de serviços.

Esses posicionamentos conflitantes entre países em desenvolvimento e países desenvolvidos mantêm-se até hoje. A relutância dos países em desenvolvimento em negociar qualquer novidade no setor de serviços enquanto não forem dirimidos os impasses nas negociações de bens tem impedido qualquer avanço nas negociações no âmbito do GATS durante a lenta e entravada Rodada Doha.

Em contrapartida, alguns países desenvolvidos continuam insistindo na necessidade de compromissos mais amplos e significativos no setor de serviços, sugerindo inclusive a 
adoção de compromissos obrigatórios mínimos (chamados benchmarks) ${ }^{321} \mathrm{em}$ todos os setores e subsetores para que a liberalização do comércio de serviços seja de fato efetiva. Essas propostas, no entanto, estão em total desacordo com os princípios do GATS, que explicitamente reconhece o direito dos países de liberalizar progressivamente conforme suas situações individuais de desenvolvimento.

De qualquer forma, as negociações no setor de serviços, ainda bastante atreladas aos acontecimentos nas mesas de negociação do comércio de bens agrícolas e não agrícolas, estão paradas, não tendo apresentado qualquer mudança significativa.

Assim como as todas as negociações no âmbito da OMC, os debates sobre a liberalização do comércio de serviços estão cada vez mais atrelados ao problema do desenvolvimento. Isso porque o setor de serviços no comércio internacional é, assim como o comércio de bens, bastante marcado por desigualdades entre os Estados participantes.

Além disso, evidente que o comércio internacional de serviços é fundamental para a economia dos países, vez que o setor de serviços representa hoje cerca de dois terços do produto mundial bruto e tem demonstrado o maior crescimento no comércio internacional $^{322}$. E, ainda, o setor de serviços é bastante relevante no que tange à proteção e garantia dos direitos humanos, diante da gama de serviços básicos (educacionais, de saúde, de infraestrutura, ambientais, entre outros) que são fundamentais para o efetivo exercício desses direitos, em especial do direito ao desenvolvimento.

O acesso e a qualidade dos serviços básicos, como a educação, deve, portanto, estar sempre presente como prioridade nas discussões sobre o futuro e os métodos aplicados ao comércio de serviços, uma vez que as disposições do GATS prevêem que as negociações no setor deverão buscar a realização do desenvolvimento. E desenvolvimento, neste caso, só poderia ser entendido de forma ampla, como direito humano fundamental, que obriga toda a comunidade internacional, incluindo, por óbvio, os países em suas relações no âmbito da OMC.

\footnotetext{
${ }^{320}$ Proner, 2003, p. 73.

${ }^{321}$ A proposta de negociações de benchmarks suplementariam a atual abordagem nas negociações comerciais em serviços, que são regidas pelo método de pedidos e ofertas. Nesta lógica, os países apresentam propostas contendo suas ofertas (quais compromissos aceitam assumir) e pedidos (quais suas demandas de abertura para os demais Membros) e recebem o mesmo dos outros países. O método de negociações em serviços por pedidos e ofertas foi estabelecido pela OMC, por meio do documento "Linhas Mestras e Procedimentos de Negociação" (Diretrizes, S/L/93).

${ }^{322}$ Cunha, 2005, p. 18.
} 
Assim, no próximo item, será analisado especificamente o setor de serviços educacionais dentro do comércio internacional e as conseqüências das determinações do GATS para o seu reconhecimento como bem público e direito humano.

\subsection{OS SERVIÇOS DE EDUCAÇÃO E AS REGRAS DE LIBERALIZAÇÃo COMERCIAL: APESAR DA CONTRADIÇÃO}

Conforme já mencionado anteriormente, o GATS não logrou definir o conceito de serviços, que permanece como um conceito residual. No entanto, deve-se ressaltar que o seu artigo I, parágrafo $3^{\circ}$, alínea " $b$ " esclarece que o termo serviços inclui qualquer serviço em qualquer setor, exceto aqueles prestados no exercício da autoridade governamental, sendo que estes são classificados no GATS como qualquer serviço que não seja prestado em uma base comercial, ou em concorrência com um ou mais prestadores de serviços.

Em outras palavras, O GATS prevê a liberalização progressiva de todos os setores previstos em seu texto, com exceção daqueles serviços que são de fornecimento exclusivo das autoridades públicas nacionais e que não concorrem com qualquer entidade privada na prestação do serviço.

Por este motivo, durante o período de 1995 a 1999, enquanto ainda não estavam definidos os setores sobre os quais o GATS se aplicaria, esperava-se que os serviços educacionais não fossem incluídos no rol de setores sujeitos às regras do Acordo. No entanto, o reconhecimento da possibilidade da prestação dos serviços educacionais pela iniciativa privada nacional abriu as portas para que a educação não fosse enquadrada entre os serviços prestados no exercício da autoridade governamental. Afinal, uma vez que o setor está aberto para a iniciativa privada nacional, tornou-se mais fácil defender na OMC a idéia de que deveria ser permitida a prestação destes serviços também por empresas estrangeiras.

Assim, o setor de serviços educacionais foi incluído no âmbito do GATS como um dos setores de serviços a ser objeto de compromissos de liberalização pelos países Membros da OMC. Isso significa que todos os países Membros do GATS estão comprometidos com a liberalização (ainda que progressiva) do setor educacional.

Mais do que isso, se um país assumir compromissos neste setor em suas listas positivas, todas as regras, princípios e, em especial as obrigações dos Estados, definidas no GATS, passam a ser aplicadas ao comércio internacional de serviços educacionais, com o objetivo de alcançar a liberalização progressiva do setor. 
Os objetivos de liberalização comercial no setor de serviços educacionais implicam tratar da educação de acordo com as regras do direito do comércio internacional, ou seja, como mercado ou mercadoria. Esta condição entra em conflito com a proteção dada pelo Direito Internacional dos Direitos Humanos ao direito à educação e ao direito ao desenvolvimento.

Grande parte dos países membros da OMC já ratificou alguma das convenções internacionais de proteção ao direito à educação, nas quais este é entendido como um direito fundamental da pessoa humana. Portanto, é importante atentar para os verdadeiros efeitos de uma liberalização e seus impactos sociais no setor educacional. Isso porque, se a inclusão de compromissos no GATS sobre este setor prejudicar a realização do direito à educação e do direito ao desenvolvimento de alguma forma, os Estados estarão incorrendo em violações de direitos humanos, que deverão ser combatidas pela comunidade internacional em prol do livre e efetivo desenvolvimento dos seres humanos.

De qualquer forma, o setor de serviços educacionais já está inserido no GATS e a sua exclusão é muito pouco considerada pelos representas governamentais dos Estados Membros da OMC. Mesmo os mais céticos quanto aos benefícios do comércio internacional admitem que a retirada do tema das negociações no GATS parece bastante utópica.

Diante desta situação, deve-se, antes de avaliar os reflexos dessa inclusão para a educação como bem publico e direito humano universal, apresentar de que forma o setor educacional encontra-se definido e delimitado no âmbito da OMC, quais as propostas apresentadas para o setor, quais os compromissos já assumidos e quais as perspectivas para as negociações futuras.

\subsubsection{Definição e classificação dos serviços educacionais no GATS}

O setor educacional é dividido no GATS em cinco sub-setores, quais sejam:

1) Educação primária: engloba a pré-escola e outros serviços de educação primária ${ }^{323}$;

2) Educação secundária: refere-se ao ensino secundário, seja ele técnico ou regular ${ }^{324}$;

\footnotetext{
323 "PRIMARY EDUCATION SERVICES (CPC 921), which comprises Preschool Education Services (CPC 92110) and Other Primary Education Services (CPC 92190). These categories do not include child-care services (considered as social services in CPC 93321) and services related to literary programmes for adults, which are part of the sub-category Adult Education Services (CPC 92400)”. (MTN.GNS/W/120). 324 "SECONDARY EDUCATION SERVICES (CPC 922), which comprises General Secondary Education Services (CPC 92210), Higher Secondary Education Services (CPC 2220), Technical and Vocational Secondary Education Services (CPC 92230), and Technical and Vocational Secondary Education Services for handicapped students (CPC 92240)". (MTN.GNS/W/120).
} 
3) Educação superior: é o ensino pós-secundário técnico ou regular, além da educação vocacional e outros serviços de educação superior que levem à obtenção de um diploma universitário ou equivalente ${ }^{325}$;

4) Educação para adultos: cobre o ensino a adultos que esteja fora do sistema educacional regular ${ }^{326}$;

5) Outros serviços relacionados à educação: demais serviços educacionais que não estejam previstos nas categorias anteriores ${ }^{327}$.

A definição do conceito de serviços educacionais para a OMC se dá, portanto, com base no conteúdo de cada um dos seus sub-setores. A classificação dos serviços educacionais em 5 sub-grupos foi elaborada pela Services Sectoral Classification List, desenvolvida durante a Rodada Uruguai e baseada na lista da CPC, da ONU. As atividades inseridas na Services Sectoral Classification List foram, portanto, definidas em referência aos códigos da CPC.

Essa classificação não é pacificamente aceita por todos os Membros da $\mathrm{OMC}$, sendo que alguns países têm assumido compromissos de acordo com classificações diferentes. Em geral, apesar de não serem as mesmas classificações, as categorias a que se referem são parecidas, não havendo, até o momento, confusão acerca da utilização de metodologias diversas. No entanto, isso ainda poderia ocorrer, motivo pelo qual os países têm debatido a uniformização das listas, porém sem sucesso até então.

Assim, os compromissos assumidos pelos países membros da OMC são feitos separadamente em cada um dos subsetores da educação e ainda, de acordo com os quatro modos de prestação de serviços comuns às negociações em todos os setores de serviços, visto já que os serviços educacionais podem ser prestados em qualquer das modalidades de prestação $^{328}$.

\subsubsection{As negociações comerciais dos serviços educacionais: propostas e compromissos}

325 "HIGHER EDUCATION SERVICES (CPC 923) including Post-Secondary Technical and Vocational Education Services (CPC 92310) and Other Higher Education Services (CPC 92390). The former refers to sub-degree technical and vocational education, while the latter refers to education leading to a university degree or equivalent". (MTN.GNS/W/120).

326 "ADULT EDUCATION (CPC 924) covering education for adults outside the regular education system". (MTN.GNS/W/120).

327 "OTHER EDUCATION SERVICES (CPC 929), covering all other education services not elsewhere classified, and excluding education services regarding recreation matters, for example, those provided by sport and game schools, which fall under sporting and other recreation services (CPC 964). For complete definitions see (Table 9)". (MTN.GNS/W/120).

${ }^{328}$ Ver os exemplos específicos para o comércio de serviços educacionais no item supra V.3.1. 
As propostas e compromissos no setor de serviços educacionais são poucas. Até o momento apenas cinco dos $153^{329}$ Estados Membros da OMC apresentaram propostas nas quais dispõem sobre a forma de tratamento dos serviços educacionais na OMC e sugerem alterações.

A proposta apresentada pelos $\mathrm{EUA}^{330}$ tem por objetivo estreitar os objetivos das possíveis negociações dos serviços educacionais sob o GATS. Para tanto, refere-se exclusiva e unicamente ao setor da educação terciária privada, sendo que suas sugestões não se aplicam à educação primária e secundária.

O governo estadunidense esclarece ainda que a educação superior engloba todas as formas de educação terciária, de educação de adultos e de serviços de treinamento, sendo que a primeira sugestão deste país é a inclusão de outro tipo de serviço como parte do conceito de educação: os serviços de testes educacionais (educational testing services).

O objetivo da proposta estadunidense é criar condições favoráveis aos fornecedores de serviços de educação superior, educação de adultos e de treinamento, por meio da remoção e redução dos obstáculos impostos a estes serviços na prestação transfronteira por meios eletrônicos ou físicos, bem como dos obstáculos ao estabelecimento ou operação de escolas, salas de aulas e escritórios, que prestarão os serviços aos estudantes tanto em seu território como no estrangeiro.

Assim, recomenda que os países Membros da OMC assumam compromissos de acesso a mercados e tratamento nacional nas categorias de educação superior, educação de adultos e de serviços de treinamento, com vistas a eliminar barreiras à liberalização comercial do setor, identificadas pelo governo dos EUA ${ }^{331}$.

Mesmo assim, a proposta dos EUA afirma reconhecer: (i) a importância dos Estados manterem o seu direito de regular os objetivos de sua política doméstica; (ii) que a educação é um direito fundamental, de garantia governamental; (iii) que os serviços relacionados à educação pública poderiam ser complementados pela iniciativa privada, desde que respeitadas as regras de cada país sobre o fornecimento de educação pública a seus cidadãos; (iv) a importância da não intervenção na área fiscal; (v) que a concessão de

\footnotetext{
${ }^{329}$ Número total de países Membros da OMC em janeiro de 2009. Informações disponíveis no site da OMC: $<$ www.wto.org >. Acesso em 15 jan. 2009.

${ }^{330}$ S/CSS/W23, de dezembro de 2000.

${ }^{331}$ Exemplo de barreira identificada na proposta são os impedimentos para a obtenção de autorização para instalar instituições de ensino no território de outros Membros, restrições quanto ao reconhecimento de diplomas, requerimento de contratação mínima de pessoal nacional, entre outros.
} 
subsídios à educação superior nacional não precisa ser estendida, em igualdade, aos prestadores estrangeiros; e (vi) o direito dos países de manterem reservas quanto ao sistema educacional público.

A proposta da Nova Zelândia ${ }^{332}$, por sua vez, tem o escopo de sugerir que os compromissos estejam sempre contemplados em setores que são menos sensíveis às divergências entre políticas públicas e atividade comercial. Para identificar esses setores mais relevantes ao comércio internacional, a Nova Zelândia propõe melhorias à classificação dos serviços educacionais.

Assim, sugere que nas categorias de educação superior, de adulto e demais serviços educacionais (residual) sejam elencadas de forma não exaustiva, mas sim ilustrativa, alguns exemplos que refletiriam melhor a realidade dos serviços prestados naquelas categorias. Propõe ainda a inclusão de novos conceitos, como os EUA.

Todas essas recomendações devem ser vistas com atenção à preocupação do governo neozelandês quanto à necessidade de se estabelecer um equilíbrio entre as prioridades educacionais domésticas e as formas de liberalização do comércio de serviços educacionais.

A proposta da Austrália ${ }^{333}$ não possui um escopo especificamente definido, mas se volta à identificação das barreiras e impedimentos ao comércio de serviços educacionais. Assim, identifica as principais barreiras encontradas em cada modo de prestação dos serviços educacionais.

No Modo 1, os impedimentos estariam nas barreiras governamentais no fornecimento de serviços educacionais pela Internet. No Modo 2 e 4, as principais barreiras diriam respeito às dificuldades de obtenção de vistos, bem como as divergências quanto ao reconhecimento de diplomas estrangeiros. Por fim, no Modo 3, as limitações à participação do capital estrangeiro deveriam ser combatidas.

Ressalta ainda a necessidade de as negociações serem conduzidas com respeito aos princípios relacionados à política doméstica, como o acesso aos serviços educacionais de melhor qualidade aos consumidores, a impossibilidade de se proibir o Estado de estabelecer seus próprios objetivos de política educacionais, inclusive quanto ao direcionamento de recursos públicos para a educação nacional, entre outros.

\footnotetext{
${ }^{332}$ S/CSS/W/93, de junho de 2001.

${ }^{333}$ S/CSS/W/110, de outubro de 2001.
} 
O Japão ${ }^{334}$ foi o quarto país a apresentar propostas sobre o comércio de serviços educacionais. O objetivo da proposta japonesa é encorajar a liberalização por meio de maior acesso a mercados, segurança do tratamento nacional e desregulamentação das regras internas contendo empecilhos ao comércio do setor.

Ao mesmo tempo, reconhece que as medidas de liberalização deverão ser voltadas ao interesse da melhoria na qualidade dos serviços, levando em consideração aspectos dos objetivos da política governamental. Ressalta ainda, que devido a programas sociais distintos e aos diferentes níveis de evolução do sistema educacional entre os Membros da OMC, a estrutura do sistema de ensino em cada país varia bastante, assim como o papel atribuído ao Estado.

A preocupação com a qualidade do ensino faz com que a proposta japonesa questione o fornecimento dos serviços educacionais pelo Modo 1, ou seja, pelo ensino à distância, por se tratar de uma maneira muito diferente estruturalmente de prestar os serviços educacionais.

Por fim, a proposta mais recente apresentada aos Membros da OMC foi a comunicação da Suíça ${ }^{335}$, que na apresenta objetivos específicos, mas apenas relata como é regulamentado o setor internamente, sugerindo a sua experiência como exemplo para os demais Membros. No sistema educacional suíço há uma coexistência entre o ensino público e o privado e apresenta dados que indicam o país como o segundo país com o maior número de estudantes estrangeiros em comparação ao número de estudantes nacionais. A Suíça assumiu compromissos específicos nos subsetores da educação primária, secundária e superior, defendendo a abertura do setor educacional à entrada de instituições estrangeiras.

Da breve análise feita acima, é possível identificar que todas as propostas apresentadas até o momento apontam, em menor ou maior grau, para a necessidade de liberalização dos serviços educacionais, identificando as principais barreiras à livre circulação de prestadores de serviços educacionais estrangeiros.

Apesar disso, todas as propostas atentam - ao menos no discurso - para o importante papel do Estado, a quem deve ser assegurado o direito de regulamentar a educação conforme suas regras e princípios internos. Nenhuma das propostas, porém, consegue determinar de que forma essas duas linhas podem atuar juntamente.

\footnotetext{
${ }^{334}$ S/CSS/W/137, de março de 2002.

$335 \mathrm{TN} / \mathrm{S} / \mathrm{W} / 39$, de abril de 2005.
} 
Além disso, as propostas também demonstram um enfoque maior nos serviços de educação superior, sendo que a educação primária e secundária permanece como um tema bastante delicado, especialmente a primeira, diante da obrigação da gratuidade do ensino primário a todos, prevista nos instrumentos internacionais de direitos humanos e nos ordenamentos internos dos países, como é o caso do Brasil.

Conforme demonstrado anteriormente, a educação superior tem sofrido maiores pressões em termos de liberalização comercial, visto a predominante presença da iniciativa privada no fornecimento desses serviços. Além disso, a caracterização da educação superior como direito humano e bem público internacional sofre mais críticas e apresenta maior número de opiniões em contrário, o que facilita o avanço das negociações sobre o setor na OMC, já que é menos espantoso para alguns tratar-se da educação superior como um negócio lucrativo ou um mercado em expansão.

Daí a relevância de se estudar a educação superior como o direito humano que é e como peça fundamental para o direito ao desenvolvimento. A facilidade e a naturalidade com que se têm tratado do setor nas negociações comerciais é, de certa forma, espantosa, já que restou evidente no capítulo anterior, que a educação superior possui aspectos sociais, políticos, filosóficos, psicológicos e culturais extremamente relevantes para o indivíduo e para a sociedade, sendo qualquer discussão sobre a sua comercialização deve ser tratada com as devidas cautelas para que tais aspectos possam produzir frutos para os seres humanos, para a sociedade e para o desenvolvimento de ambos.

O presente estudo, portanto, ao analisar a relação entre a educação superior e o direito ao desenvolvimento, bem como sua inclusão nas negociações da OMC, quer apresentar a necessidade de se tratar a educação superior com o mesmo receio e cuidado que se trata da educação primária entre os representantes governamentais dos países na Organização.

Assim, ainda que os temas abaixo sejam tratados com vistas às negociações sobre serviços educacionais como um todo (em qualquer nível), deve-se considerar que os argumentos empregados aplicam-se necessariamente à educação superior. Portanto, ao analisar as considerações levantadas no presente trabalho, deve-se sempre ter em mente a atenção especial dada explicita ou implicitamente à educação superior, a fim de combater a maior fragilidade do seu reconhecimento como direito humano e bem público entre os Membros da OMC. 
Antes de se passar à análise das conseqüências do tratamento da educação como bem de mercado, deve-se ressaltar que, no tocante à presença do setor nas listas positivas dos países, apenas 47 Membros da OMC assumiram algum compromisso específico sobre serviços educacionais. No subsetor de serviços de educação superior, há 39 países com compromissos assumidos $^{336}$, com o maior número de compromissos entre os demais níveis da educação.

\subsubsection{A educação e os serviços prestados no exercício da autoridade governamental}

Conforme mencionado anteriormente, antes da determinação dos setores de serviços que estariam sujeitos às normas do GATS, esperava-se que os serviços educacionais não fossem inseridos no âmbito do Acordo, por constituírem obrigações e funções do Estado. Acreditava-se, portanto, que os serviços educacionais fossem enquadrados no artigo I, parágrafo $3^{\circ}$, alínea "c", do GATS, que prevê que os serviços prestados no exercício de autoridade governamental, que não estão sujeitos às normas do GATS, caracterizam-se como aqueles não prestados em uma "base comercial" e nem "em concorrência" com outros fornecedores.

Por serviços prestados em uma base comercial, deve-se entender, em princípio, que tratamse de atividades lucrativas. O problema dessa definição é que quase todos os serviços, ainda que público, podem ser prestados em bases comerciais. Assim, uma universidade pública brasileira, apesar de oferecer o ensino gratuito aos estudantes, pode prestar serviços cobrados ao mercado.

Da mesma forma, a idéia de estar em concorrência é muito amplo, não havendo limites para o seu alcance. Assim, uma universidade pública que utiliza os tradicionais métodos de aulas expositivas presenciais teria como concorrentes os prestadores estrangeiros de educação virtual com o intuito lucrativo ${ }^{337}$. Portanto, sempre que o Poder Público delegasse a sua função de exercer serviços educacionais à iniciativa privada, estará necessariamente em concorrência com os prestadores privados.

\footnotetext{
${ }^{336}$ Para os demais subsetores, os números são ainda menores, ainda que não muito diferentes. Para a educação primária, existem 32 países com compromissos assumidos; para a secundária, são 38 , o mesmo número para a educação de adultos. Para o subsetor residual "outros serviços educacionais", são apenas 22 Membros com compromissos assumidos. Dados disponíveis no site da OMC: <www.wto.org >. Acesso em: 15 jan. 2009.

${ }^{337}$ Knight, 2002, p. 9.
} 
Conclui-se, assim, que os termos que definem o que são serviços prestados no exercício de autoridade pública são muito amplos e englobam diversas situações, de modo que é quase impossível que algum serviço educacional prestado pelo Estado seja excluído do GATS.

Por isso, os serviços educacionais acabaram por ser inseridos na OMC como sujeitos ao GATS, diante da possibilidade da prestação dos serviços educacionais pela iniciativa privada, já que entendeu-se que os serviços prestados por entidades privadas, em base comercial, já que visam ao lucro, competem entre si. Portanto, já que as "empresas" nacionais de ensino competem entre elas, nada impede que passem a competir com "empresas" de educação estrangeiras.

Ocorre que esse entendimento não leva em consideração que a natureza dos serviços prestados é a mesma, seja quando fornecidos pelos Estados ou quando prestados por instituições privadas, ou seja, a educação é sempre um direito humano e um bem público, não importando se fornecida pelo Estado ou por instituições privadas, se confere lucro ou não, se possui concorrentes ou não.

Felizmente, o reconhecimento dos serviços educacionais como um setor sensível política e socialmente às negociações multilaterais de comércio é bastante difundido, sendo que a maioria dos países e das organizações internacionais ainda tende a ver esses serviços como uma função primordialmente pública, de responsabilidade do Estado.

A disseminação deste entendimento é bastante clara quando se vem a saber que a grande maioria dos países Membros da OMC tem agido com alguma cautela e prudência no que tange ao estabelecimento de compromissos de liberalização no âmbito do GATS para serviços educacionais $^{338}$. Assim, nenhum país ousou assumir compromissos no setor sem determinar algum tipo de restrição ou limitação.

E essa constatação é ainda mais evidente ao verificar-se que, apesar da educação primária e secundária estarem previstas como categorias liberalizáveis no GATS, quase todos os países rejeitam, até o momento, tratar de medidas para abertura do setor nestes níveis, por reconhecê-los como direitos humanos universais.

O mesmo, porém, não ocorre com os serviços de educação superior, onde reside a maior parte das propostas apresentadas e dos compromissos assumidos dentro de serviços educacionais no âmbito do GATS.

${ }^{338}$ Primo, 2005, p. 297. 
Não haveria motivos, porém, para a exclusão da educação superior do tratamento como direito humano. Isso porque evidente, conforme demonstrado e reafirmado, que a educação superior exerce papel fundamental para o desenvolvimento humano e para o crescimento da sociedade, sendo parte essencial do direito à educação em plenitude e peça chave na realização do direito ao desenvolvimento.

Isso porque o fato da educação superior ser fornecida em grande escala pela iniciativa privada não lhe descaracteriza como serviço público. O próprio Secretariado da OMC, em estudo publicado em 2002, já ressaltou que:

(...) é perfeitamente possível que os serviços governamentais coexistam na mesma jurisdição com os serviços privados. No caso dos setores da saúde e educação isto é tão comum, se não é propriamente a regra. Embora não tenha nunca havido uma disputa ou outra ocasião demandando pela interpretação do artigo I:3, parece claro que a existência de serviços de saúde privado, por exemplo, em paralelo com os públicos, não invalida o status do último como serviços governamentais ainda mais pelo seu significado. Este dispositivo foi de importância política para todos os Membros na negociação e não há razão em acreditar que eles concordariam em comprometê-lo ou distorcê-lo agora ${ }^{339}$.

Assim, haveria motivos suficientes para que os serviços educacionais, inclusive os de educação superior, fossem enquadrados nas exceções do GATS aos serviços realizados no exercício da autoridade governamental, nos termos do seu artigo I, parágrafo 3, alínea "b", que dispõe expressamente que "o termo 'serviços' abrange serviços em todos os setores, com exceção dos serviços prestados no exercício da autoridade do Estado".

Ainda assim, o fato é que os serviços de educação e, em especial, os de educação superior, estão inseridos nas negociações de liberalização do comércio na OMC, que, afirma reconhecer a importância dos serviços educacionais e sua tênue separação com os serviços públicos, respeitando o papel do Estado como principal responsável e garantidor da educação como direito humano. No entanto, é possível dizer que a inserção desses serviços na $\mathrm{OMC}$ e as conseqüentes obrigações que os Estados devem cumprir pela liberalização contribuem para a efetividade desta prerrogativa?

\subsubsection{Os impactos dos compromissos de liberalização comercial sobre a educação}

Conforme já mencionado anteriormente, o simples fato de serem Membros da OMC e, conseqüentemente, partes do GATS, já impõe aos Estados uma primeira obrigação: a de

${ }^{339}$ OMC, 2001, p.124. 
promover a liberalização progressiva de todos os setores de serviços ${ }^{340}$ incluídos no Acordo, entre eles, os educacionais.

Ainda mais atrelados estarão os países que assumirem compromissos específicos sobre serviços educacionais, ficando sujeitos às obrigações do GATS sobre acesso a mercados e tratamento nacional neste setor. Além disso, determinações, como a eliminação de empecilhos internos ao provimento dos serviços educacionais e a impossibilidade de elaboração de novas regras que dificultem a entrada de prestadores de serviços educacionais estrangeiros, também obrigam aqueles que assumam compromissos específicos no setor.

Pode-se dizer, portanto, que, a partir do momento em que o setor de serviços educacionais encontra-se previsto nos objetivos de liberalização da OMC, os países estarão diretamente comprometidos a eliminar "barreiras" à livre circulação dos serviços educacionais estrangeiros.

De acordo com Gustavo Ferreira Ribeiro ${ }^{341}$, essas barreiras ao comércio, no setor educacional, poderiam ser identificadas por cada modo de prestação dos serviços. Assim, no Modo 1 (serviços transfronteiriços), restrições à transmissão eletrônica de materiais, impossibilidade de reconhecimento ou credenciamento da instituição estrangeira, carga excessiva de impostos ou taxas para a licença ou pagamento de royalties, seriam medidas combatidas pelos países fornecedores de serviços educacionais. Os países demandados, portanto, seriam pressionados a modificar tais medidas, em cumprimento aos compromissos que porventura tenham assumido.

O mesmo ocorreria com as medidas consideradas barreiras ao comércio de serviços educacionais no Modo 2 (consumo no exterior), tais como exigência de visto, exigência de câmbio de moeda, exigência de qualificação prévia de outros países e restrições de trabalho ao estudante estrangeiro.

No Modo 3 (presença comercial), as principais "barreiras" combatidas seriam a impossibilidade de obter licença nacional para reconhecer os diplomas dos estudantes, limitação nos investimentos diretos pelos prestadores de serviço, exigência de nacionalidade, monopólios governamentais e o elevado grau de subsídio ao prestador nacional.

\footnotetext{
${ }^{340}$ Trata-se dos 12 setores aos quais se aplicam os dispositivos do GATS. Ver item IV.3.

${ }^{341}$ Ribeiro, 2006, p. 6.
} 
Por fim, no Modo 4 (presença de pessoas físicas), Ribeiro destaca que exigências de imigração, requerimentos de nacionalidade, testes, quotas no número de funcionários temporários, entre outras medidas, seriam consideradas barreiras ao comércio de serviços educacionais, que devem ser combatidas por todos os Membros da OMC, em especial por aqueles que tenham assumido compromissos específicos pela liberalização do comércio de serviços educacionais.

Assim, a inclusão de compromissos no setor educacional trará, de início, obrigações ao Estado, decorrentes do princípio da cláusula da nação mais favorecida, do princípio do tratamento nacional, sobre as regras de reconhecimento e, em especial, sobre a adequação da regulamentação doméstica do setor pelo Estado.

Sobre as obrigações decorrentes do princípio da cláusula da nação mais favorecida, Ribeiro $^{342}$ destaca que os poucos estudos que analisam essa relação indicam que, uma vez assumidos compromissos no setor de serviços de educação superior, os Estados que concederem autorizações ou credenciarem determinada instituição, deverão estendê-las aos demais.

Apesar de a concessão da autorização ou credenciamento às demais instituições estar adstrita ao cumprimento dos mesmos requisitos, o surgimento de outros fatores determinantes para a concessão desses "benefícios" não importará, sendo que novas exigências não poderão ser impostas.

Dessa forma, ocorreria um efeito cascata decorrente da aplicação da cláusula da nação mais favorecida, pois uma vez obtido o acesso ao mercado de serviços educacionais por um Membro, os demais poderiam dele se beneficiar.

Outras obrigações a que os Estados estariam automaticamente atrelados ao assumir compromissos específicos para os serviços educacionais na OMC decorreriam do princípio do tratamento nacional.

Ribeiro $^{343}$ analisa esses impactos na prestação dos serviços no Modo 3 e no Modo 2, diante de um cenário em que um Estado assume um compromisso de liberalização dos serviços educacionais e não coloca restrições ou limitações como exceções ao tratamento nacional.

\footnotetext{
${ }^{342}$ Ribeiro, 2004, p. 78.

${ }^{343}$ Ribeiro, 2004, p. 79.
} 
No Modo 3, que deveria permitir o estabelecimento de instituições de ensino estrangeiras em paridade com as instituições nacionais, indaga se haveria conflito entre a obrigação decorrente do princípio do tratamento nacional e a política de financiamento educacional (subsídios) de cada Membro, preocupando-se, portanto, com a possibilidade de o financiamento da educação superior ser afetado em razão deste princípio.

Já no Modo 2, pergunta-se se os estudantes estrangeiros deveriam receber tratamento igual em relação aos estudantes nacionais de um Membro.

As implicações do estabelecimento de compromissos no GATS relativas às obrigações de reconhecimento, no caso da educação superior, possuem duas dimensões principais, que se encontram tradicionalmente sob forte regulamentação estatal: (i) o credenciamento de cursos e instituições de ensino superior; e (ii) a revalidação de diplomas.

Assim, teme-se que as regras do GATS acabem por forçar mudanças nas legislações nacionais para o amplo e mais fácil reconhecimento dos diplomas estrangeiros. Da mesma forma, a inserção de compromissos específicos no setor, ainda que com restrições e limitações, facilitaria que países interessados na abertura deste mercado pressionassem os demais países por mudanças legislativas quanto ao credenciamento das instituições de ensino estrangeiras, fazendo com os países acabem decidindo como regulamentar o setor com base nas suas preocupações com seu status nas relações comerciais internacionais.

O problema do reconhecimento, portanto, toca a capacidade do Estado de promover alterações em sua legislação interna, mesmo aquelas que venham a refletir políticas públicas de cunho social adotadas pelo Estado.

Lembre-se que, apesar de haver dispositivos no GATS que reconhecem a importância do papel do Estado e lhe dão, ao menos em tese, o direito de regulamentar os setores de serviços em consonância com suas regras e políticas internas, o Acordo também determina que todas as medidas governamentais - editadas na forma de lei, regulamento, regra, procedimento ou decisão administrativa, entre outras - estão sujeitas às regras de liberalização progressiva do $\operatorname{GATS}^{344}$. Isso significa que os países Membros da OMC estão obrigados a adequar suas legislações internas aos princípios e regras do $\operatorname{GATS}^{345}$.

\footnotetext{
${ }^{344}$ Celli Jr., 2008(b), p. 5.

345 Sobre as relações entre o espaço para políticas públicas, no tocante à regulamentação doméstica dos Estados, e os compromissos assumidos no GATS e a necessidade de se permitir que os países em desenvolvimento se utilizem da flexibilidade do GATS para garantir políticas de desenvolvimento, ver a tese de livre docência do professor Umberto Celli Jr., 2008(a).
} 
Ressalte-se, por fim, que ao assumir compromissos específicos no GATS para o setor educacional, os países estarão sujeitos à jurisdição do Órgão de Solução de Controvérsias da OMC, sendo que se um país Membro entender que os compromissos assumidos por outro não estão sendo cumpridos, poderá levá-lo aos "juízes” da OMC, que poderão decidir a favor do reclamante, gerando a ele um direito de reparação e obrigações ainda maiores para o país demandado.

\subsection{A POSIÇÃO BRASILEIRA E O DIREITO CONSTITUCIONAL À EDUCAÇÃO}

Atualmente, o Brasil não possui qualquer compromisso assumido no setor de serviços educacionais, em qualquer dos seus níveis e até o momento, o governo brasileiro manifestou pouco interesse na inclusão do setor em sua lista positiva de compromissos.

O governo brasileiro tem adotado uma postura constante na OMC de utilizar a grande demanda interna por serviços e bens industrializados como moeda de troca por avanços nas negociações do setor agrícola, o que, como é de conhecimento geral, tem travado as negociações da atual Rodada Doha, que parece não conseguir escapar do impasse resultante dos conflitos entre países desenvolvidos e em desenvolvimento sobre o comércio de bens.

Recentemente, porém, em pedido plurilateral formulado por alguns países demandantes em serviços educacionais - China-Taiwan, Malásia, EUA e Nova Zelândia -, o Brasil e a Argentina foral solicitados a apresentar ofertas de acesso ao mercado de ensino técnico e profissional pós-segundo grau e de serviços de ensino destinados à obtenção de título universitário ou equivalente ${ }^{346}$.

No entanto, ao contrário da posição receosa do Brasil na OMC, o "mercado educacional" brasileiro permanece aberto, sendo que a presença da iniciativa privada estrangeira nos serviços de educação, principalmente no ensino superior, continua a crescer a passos rápidos.

É bem verdade que o fornecimento dos serviços educacionais por qualquer entidade privada, nacional ou estrangeira, deverá estar adstrita à regulamentação interna sobre o setor, devendo obedecer aos requisitos mínimos e determinações do MEC e da Lei de Diretrizes e Bases, como submeter seus alunos à avaliação geral dos cursos (o Enade ou "Provão").

\footnotetext{
${ }^{346}$ Celli Jr., 2008(b), p. 5.
} 
Ressalte-se o disposto no artigo 209, da Constituição Federal, que determina que a atividade econômica educacional, realizada por instituições privadas, deve atender aos seguintes requisitos e condições: (i) o cumprimento de normas gerais da educação nacional; (ii) autorização; e (iii) avaliação de qualidade pelo Poder Público.

Ainda assim, à medida que o número de instituições de ensino privadas, estrangeiras e nacionais, aumenta no território brasileiro, surgem indícios da queda na qualidade geral do ensino no país. É o que verificou a Coordenação de Aperfeiçoamento de Pessoal de Nível Superior (CAPES), que chegou a receber até dez denúncias de cursos irregulares no país, após verificar-se uma invasão de cursos de mestrados e doutorado ministrados por instituições estrangeiras ${ }^{347}$.

Diante desta constatação, em 2001, o Conselho Nacional da Educação (CNE) ${ }^{348}$ editou a Resolução $\mathrm{n}^{\mathrm{o}} 2^{349}$, proibindo a admissão de novos alunos em cursos de mestrado estrangeiros. Ressalte-se que, se o Brasil, tivesse assumido compromissos específicos no setor educacional perante o GATS, esta medida poderia ser interpretada como clara violação às obrigações e princípios da $\mathrm{OMC}$, colocando o país em situação bastante complexa: defender a qualidade de ensino no país, como medida de desenvolvimento social e humano ou manter estáveis as relações comerciais com os demais países?

É bem verdade que a culpa pelo problema da qualidade da educação no Brasil não é das instituições privadas, nacionais ou estrangeiras, já que trata-se, em verdade, de um problema social histórico da nação, que não quer-se analisar no presente estudo.

No entanto, há fortes indícios de que a comercialização do setor pode não servir aos objetivos da educação como direito humano. Mais do que isso, a liberalização desregulada dos serviços educacionais pode ainda prejudicar o alcance dos objetivos do direito ao desenvolvimento.

Neste sentido, bem lembra Nina Beatriz Stocco Ranieri ${ }^{350}$ que "a comercialização de serviços educacionais, sobretudo, tende a aprofundar as diferenças de oportunidades educacionais existentes no País, pelo critério econômico, acentuando problemas

\footnotetext{
${ }^{347}$ Primo, 2005, p. 302.

${ }^{348}$ O Conselho Nacional da Educação é um dos órgãos do Ministério da Educação e Cultura (MEC), criado pela Lei n ${ }^{\circ}$ 9.131/1995 e responsável por elaborar e acompanhar a execução do Plano Nacional da Educação (PNE); manifestar-se sobre questões que abranjam mais de um nível ou modalidade de ensino; emitir pareceres sobre assuntos educacionais, entre outras funções.

${ }^{349}$ A Resolução n ${ }^{\circ}$ 02/2001 foi editada pelo CNE, por meio de sua Câmara de Educação Superior. Disponível em: <http://portal.mec.gov.br/cne/index.php?option=content\&task=view\&id=393\&Itemid=441>. Acesso em: 15 jan. 2009.
} 
recorrentes da educação nacional, como equidade, qualidade e eficiência, e o chamado gap tecnológico". E conclui que:

(...) a educação fica submetida ao investimento especulativo e aos interesses mercantis que orientam as iniciativas dos investidores. Ou seja, compromete-se a qualidade da educação (pautada pela relação custo/benefício), a segurança do aluno e dos profissionais de educação (considerando a possibilidade de se encerrarem as atividades das instituições de ensino, devido à falta de rentabilidade do capital) e das próprias instituições de ensino nacionais, diante da competitividade externa. Estes não são problemas triviais, tanto do ponto de vista do desenvolvimento, como do direito à educação e da proteção aos profissionais do setor.

Perceba-se que manter a defesa da presença da iniciativa privada como forma de substituição da responsabilidade do Estado, especialmente nas áreas sociais, contradiz a própria noção de direito universal inscrita na Constituição Federal. No caso da educação, Dalmo Dallari ressalta que a jurisprudência brasileira considera os serviços, mesmo quando prestados por particulares, como atividade de natureza pública, portanto delegada pelo Estado, o que, em princípio, eliminaria a possibilidade da participação de estrangeiros nesse setor ${ }^{351}$.

Lembre-se que a Constituição Federal brasileira e legislações infraconstitucionais promovem o direito humano à educação, obrigando o Estado a tomar todas as medidas necessárias para a sua implementação como direito fundamental. Note-se, porém, que a inserção do setor educacional nas negociações da OMC parece se afastar, em princípio, das preocupações com a realização dos direito humanos e do desenvolvimento, para priorizar os interesses econômicos e financeiros das empresas privadas internacionais.

As prioridades da OMC, entretanto, não poderiam exercer tamanha pressão na legislação brasileira se entrarem em choque com as disposições constitucionais sobre a proteção, promoção e garantia do direito à educação, que, como direito humano fundamental, não pode ter seu espectro reduzido em hipótese alguma.

Ressalte-se que, apesar de todas as instituições estrangeiras estarem obrigadas a atender os requisitos e condições para a prestação dos serviços educacionais, previstos na legislação brasileira, tais determinações legais são, em geral, bastante vagas em relação a autorização e controle, permitindo a proliferação ilimitada de normas regulamentares fluidas e voláteis, que não tem favorecido o controle de qualidade, ensejando, ao contrário, questionamentos acerca da legalidade e legitimidade do controle que exercem ${ }^{352}$.

\footnotetext{
${ }^{350}$ Ranieri, 2005, p. 62.

${ }^{351}$ Dallari, 2003.

${ }^{352}$ Ranieri, 2005, p. 66.
} 
Assim, percebe-se que a liberalização do setor educacional, ainda que já seja uma realidade brasileira, na qual a participação de instituições estrangeiras é crescente, toma rumos ainda mais delicados quando se fala em assumir compromissos oficiais no âmbito da OMC, já que eventuais mudanças legislativas sobre a regulamentação da educação vinculam-se inevitavelmente aos interesses econômicos que regem as negociações comerciais internacionais.

Além disso, a prática da "moeda de troca", utilizada com frequiência nos discursos brasileiros nas negociações na OMC, aplicada ao setor educacional, seria verdadeira irresponsabilidade do país para com o direito humano à educação, já que sequer estaria preocupada com as vantagens econômicas do setor. Ao contrário, esta prática prioriza apenas os interesses econômicos do setor agrícola, passando longe de qualquer preocupação com os direitos humanos, em especial com a plenitude do direito ao desenvolvimento.

Dessa forma, não restam dúvidas de que o Brasil, assim como o resto do mundo, está obrigado a priorizar a promoção da educação como direito humano em qualquer aspecto das suas relações internacionais. Só assim, o Brasil estará voltado a promover e garantir a plenitude do direito ao desenvolvimento.

\section{7. "MERCADO EDUCACIONAL" VERSUS DIREITO AO DESENVOLVIMENTO}

Apesar das contradições, o setor educacional já está definitivamente inserido no GATS, permitindo, com isso, que as empresas internacionais fornecedoras de serviços educacionais pressionem seus governos para uma maior liberalização do setor, o que, já de início, pode ser considerado um grande prejuízo à educação, que fica relacionada diretamente aos interesses meramente econômicos das grandes empresas privadas. Isso porque, dentro da OMC, a educação sempre é primordialmente vista como um setor lucrativo, que deve ser liberalizado.

Não há dúvidas de que a iniciativa privada possui hoje uma forte presença no setor educacional, porém, não é possível desvencilhar o setor da carga de importância pública que ele carrega. Afinal, foi demonstrado nos capítulos anteriores que, além de serem fundamentais para o desenvolvimento e crescimento econômico de um país, o maior acesso à educação e a melhoria na qualidade do ensino também contribuem para o desenvolvimento pessoal do indivíduo e refletem diretamente na garantia e proteção dos 
direitos humanos, em especial o direto à educação - que engloba exatamente a previsão de um maior acesso à educação para todos e a qualidade do ensino.

Dessa forma, a proteção e a garantia do direito à educação, além de contribuírem para o desenvolvimento entendido do ponto de vista meramente econômico (já que o grau de educação dos habitantes de um país influi no crescimento econômico da nação), contribuem também e principalmente para um sentido mais amplo de desenvolvimento, visto como um direito humano, que corresponde ao conceito abrangente (econômico, social, político e cultural) do direito ao desenvolvimento. Assim, o nível educacional de um país é, mais do que tudo, um redutor do seu déficit social.

Não há dúvidas, portanto, de que assegurar a realização do direito à educação é medida fundamental para a implementação plena do direito ao desenvolvimento. Assim, é imprescindível que as medidas relativas ao direito à educação, em todos os seus níveis, levem sempre em conta, antes de qualquer outro interesse, os objetivos do direito ao desenvolvimento, quais sejam, o de promover o desenvolvimento dos seres humanos, para que possam exercer efetivamente suas liberdades individuais e direitos econômicos, sociais e culturais e, assim, participar ativamente da sociedade de forma a contribuir para melhorias globais nas esferas política, econômica, social e cultural.

É bem verdade que a participação dos prestadores de serviços estrangeiros também pode trazer benefícios ao Estado e ao direito humano à educação. O aporte de investimentos estrangeiros contribui para o crescimento do setor no plano nacional e ainda estimula a concorrência, o que pode levar a uma busca pela elevação da qualidade do ensino oferecido nas diversas instituições privadas. Os investimentos estrangeiros também podem aprimorar a infraestrutura nacional, trazer novas tecnologias e fornecer melhores oportunidades de trabalho ${ }^{353}$.

Além disso, o fato de os grupos estrangeiros possuírem universidades em vários continentes facilita o intercâmbio de estudantes e professores, a quem podem ser oferecidas oportunidades de estudo fora de seu país ${ }^{354}$, promovendo a diversidade cultural e as trocas de conhecimento.

A liberalização do fornecimento de serviços educacionais no Modo 1, por sua vez, pode contribuir para o maior acesso à educação, vez que permite que indivíduos em locais com

${ }^{353}$ E/CN.4/Sub.2/2002/9, p.3. 
pouca infraestrutura física educacional possam buscar esses serviços por meio do ensino por correspondência, ou até mesmo pela Internet ${ }^{355}$.

Dessa forma, o entendimento geral é de que a liberalização dos serviços educacionais de uma forma eficiente (no sentido do livre comércio), pode promover o crescimento econômico e o desenvolvimento, fornecendo os meios econômicos necessários para a realização dos direitos humanos. Mas quase nunca essa tendência, guiada pelos objetivos do livre comércio, poderá fornecer os meios humanos, sociais, políticos e culturais necessários para a verdadeira realização dos direitos humanos.

Ressalte-se, ainda que todas essas vantagens advindas da liberalização do setor educacional pressupõem a participação ativa do Estado para que não venham a gerar, ao contrário do desejado, verdadeiras barreiras ao direito ao desenvolvimento. Isso porque, sem a participação ativa do Estado como regulamentador do setor, a concorrência entre as instituições de ensino privadas, que pode beneficiar o aumento da qualidade da educação, pode também contribuir para ressaltar as desigualdades sociais de um país ao aumentar as distâncias entre uma parcela rica e estudada da população que se favorece dos serviços estrangeiros, e uma parcela pobre e pouco instruída que deverá buscar a educação de baixa qualidade, sucateada pela concorrência privada.

Além disso, sem os necessários incentivos, os profissionais mais qualificados tendem a se aproximar das instituições privadas que oferecem remuneração mais alta, afastando-os do serviço público para contribuir para os interesses privados de verdadeiras empresas.

A ausência de regulamentação pelo Estado, portanto, permite que o enfoque sobre os objetivos comerciais das instituições privadas prevaleça sobre os princípios e regras de qualidade e acesso universal da educação.

Assim, as obrigações dos Estados e da comunidade internacional para com a promoção e garantia dos direitos humanos resultam na inevitável necessidade de realização de medidas para garantir a distribuição dos benefícios e a divisão das responsabilidades sociais advindas das negociações comerciais.

${ }^{354}$ Celli, 2008(b), p. 6.

${ }^{355}$ Ressalte-se, porém, que a prestação dos serviços educacionais pela Internet exige que referidos locais tenham a necessária infraestrutura para tanto, o que acaba sendo raro, tornando este modo de prestação de serviços educacionais não muito eficiente para esses casos. 
Ocorre que, uma vez inserida na lógica de mercado da OMC, a educação tem sido cobiçada, antes de tudo, como "mercadoria" altamente lucrativa, voltada, portanto, para satisfazer os interesses econômicos dos prestadores privados de serviços educacionais. Constata-se, assim, que, nesta perspectiva, é a esfera financeira que comanda o tipo de educação do qual a sociedade deve se apropriar e não os interesses humanos e sociais. Com essas políticas, o enfoque dado à educação passa a voltar-se para o comércio, sendo que em toda parte do mundo se comercializa o conhecimento como se comercializa qualquer outro produto ou objeto.

Assim, como Maria Arleth Pereira ${ }^{356}$ bem ressalta que "a educação vai se tornando mais utilitarista e mais instrumental, produzindo um conhecimento do momento que para nada servirá, a não ser para fabricar mercadorias e alimentar o processo de consumo enquanto valor de mercado". E ainda complementa, ao concluir que:

Nessa perspectiva, o conhecimento pautado nos valores humanos, tão necessários à sociedade, para orientar o cidadão a esclarecer seu pensamento e suas ações sobre as questões fundamentais da vida, infelizmente, passa a ter um valor de uso como produto utilitarista e fragmentado e pouco valorizado. É por essa e outras razões que as instituições educativas têm excluído dos currículos de curso a filosofia, a sociologia e a cultura geral e, com isso, a aprendizagem deixa de constituir um processo social de pensamento crítico de confrontação e análise, e passa a assumir um caráter técnico instrumental de duração rápida e descartável, que pode ser desenvolvida por qualquer empresa do ramo educacional.

Ressalte-se que os valores humanos de que trata Pereira são aqueles a que se refere quando se invoca o direito ao desenvolvimento. Assim, percebe-se que, em princípio, a mercantilização do setor educacional coloca em segundo plano valores fundamentais para a realização daquele direito humano.

Dessa forma, pode-se dizer que a inclusão dos serviços educacionais no âmbito dos compromissos comerciais assumidos no GATS certamente tem enfraquecido a idéia de que as instituições de ensino devem servir a um bem público maior, que é como deve-se enxergar o direito humano à educação. Essa constatação vai totalmente de encontro com os princípios e objetivos do direito ao desenvolvimento, aos quais todos os países e a comunidade internacional estão obrigados. Assim, os Estados possuem a responsabilidade de considerar como os compromissos assumidos internacionalmente podem afetar a realização do direito ao desenvolvimento a todos os indivíduos ${ }^{357}$.

\footnotetext{
${ }^{356}$ Pereira, 2007, p. 5.

${ }^{357}$ E/CN.4/Sub.2/2002/9, p.10.
} 
No entanto, em conseqüência deste enfraquecimento da educação como bem público e direito humano, o comprometimento dos Estados e da comunidade internacional, bem como das empresas privadas prestadoras dos serviços educacionais, também perderia força executória, sendo que os Estados perderiam espaço para realização de políticas públicas pelo aprimoramento da educação em prol do direito ao desenvolvimento, diante das pressões externas da iniciativa privada por maiores resultados lucrativos no setor ${ }^{358}$.

Em um relatório sobre as relações entre o comércio e os direitos humanos, o Alto Comissariado de Direitos Humanos da ONU ressaltou que existe uma tendência global de redução do papel do Estado, acreditando-se que as forças do mercado conseguirão resolver os problemas relativos ao bem-estar dos seres humanos, por meio da atração de investimentos de empresas multinacionais, por exemplo ${ }^{359}$.

Essa tendência desconsidera, entretanto, que o Estado tem obrigações específicas decorrentes dos direitos humanos e, em especial, no que tange aos direitos econômicos, sociais e culturais, como o direito à educação, o Estado tem um dever ativo, ou seja, é responsável pela implementação desses direitos não só como ator passivo, que apenas não interfere no gozo desses direitos pelos indivíduos, mas deve também tomar as medidas legislativas, administrativas, orçamentárias, judiciais, entre outras - necessárias para a sua plena realização.

Assim, evidente que esse esvaziamento do papel do Estado na realização dos direitos humanos não pode ser agravado pelo processo de liberalização do comércio da serviços educacionais, pois, dessa forma, os dispositivos do GATS consistiriam verdadeiras violações de direitos humanos.

Em atenção a esses impactos, o professor Umberto Celli Jr. ${ }^{360}$ destaca que:

Não há dúvidas de que o investimento na educação seja o maior instrumento de inclusão social e de desenvolvimento econômico de um país. Não pode, pois, o Estado eximir-se da responsabilidade de garantir o acesso universal à educação

\footnotetext{
${ }^{358}$ Pode-se dizer que dentro desta lógica, prevalecem os termos e práticas comerciais e da área dos negócios. Neste sentido, "Privatisation, commercialisation,bonnes pratiques, compétences, étalonnage concurrentiel (benchmarking), les 'PPP' (partenariats public-privé), prise de décision, gestion efficiente de la classe, contrat de réussite, 'bonne pratiques', 'clientèle scolaires', qualité totale, produits, reddition dês comptes, 'imputablité', performance... sont autant de termes que font le quotidien de l'administration scolairs et qui sont tous plus ou moins empruntés au monde de l'entreprise et à celui dês affaires". La lettre de l'EIP, 2006. Disponível em: <http://www.eip-cifedhop.org/lettre/archives/Lettre33/lettre33.html>. Acesso em: 15 jan. 2009.

${ }^{359} \mathrm{E} / \mathrm{CN} .4 / \mathrm{Sub} .2 / 2002 / 9$, parágrafo 10.

${ }^{360}$ Celli Jr., 2008(b), p. 5.
} 
com qualidade - sobretudo à básica - que, no Brasil é formada pela educação infantil, ensino fundamental e ensino médio. Quanto ao ensino superior, cabe ao Estado criar um sistema educacional que assegure igualdade de oportunidades de acesso às universidades públicas e que seja capaz de fomentar a pesquisa e o avanço tecnológico, dentre outros objetivos.

Percebe-se que as obrigações dos Estados e da comunidade internacional devem persistir e prevalecer, ainda que inseridas dentro de uma ordem com objetivos mercantilistas. Isso porque, apesar da existência de um "mercado da educação", o direito à educação não está no mercado ${ }^{361}$. Por isso, os Estados continuariam responsáveis pelo direito à educação, ainda que o setor fosse inteiramente privatizado e liberalizado, pois as obrigações relativas aos direitos humanos estão acima dos interesses privados do mercado, mas estão atreladas a um valor maior, o do direito ao desenvolvimento. 


\section{CONCLUSÃO}

O presente trabalho buscou apresentar as principais implicações da tendente aproximação do direito ao desenvolvimento ao comércio internacional de serviços educacionais. Assim, a partir das análises aqui desenvolvidas, procura-se fornecer um cenário de regras, compromissos e obrigações, tanto no âmbito do Direito Internacional dos Direitos Humanos como no âmbito do Direito do Comércio Internacional, que pode servir de base para o debate presente e futuro sobre os impactos do comércio internacional de serviços educacionais para o direito ao desenvolvimento, de modo a fomentar as discussões e a pesquisa sobre os possíveis caminhos para a progressiva realização do direito à educação e não para a progressiva liberalização dos serviços educacionais.

Para tanto, apresentou-se a construção do direito ao desenvolvimento, bem como a importância da educação para este processo, e o crescimento do setor de serviços educacionais na $\mathrm{OMC}$, inseridos no contexto em que se reconhecem as inter-relações entre os direitos humanos, o desenvolvimento e o comércio internacional.

Assim, verificou-se que a educação, em todos os seus níveis e, em especial para o presente trabalho, a educação superior, exerce importante papel na realização do direito ao desenvolvimento dos indivíduos, seja pelo entendimento de que o direito à educação é parte integrante do direito ao desenvolvimento, seja porque a efetividade do direito à educação é condição essencial para o direito a um processo de desenvolvimento, como um direito per se.

Conclui-se que, para que a educação alcance seus objetivos quanto à realização do direito ao desenvolvimento, o Estado e a comunidade internacional devem atuar em harmonia, de forma que todos os países devem contribuir para a realização desse direito a todos os indivíduos em qualquer lugar do mundo.

Hannah Arendt corrobora este essa necessidade de cooperação e solidariedade internacional, ao destacar sabiamente que a crença de que os problemas de um Estado estão confinados a fronteiras históricas e nacionais é invariavelmente falsa na atualidade. Isso porque "pode-se admitir como regra geral neste século que qualquer coisa que seja 
possível em um país pode, em futuro previsível, ser igualmente possível em praticamente qualquer outro país"362.

A cooperação internacional se justifica, portanto, pelo simples fato de que os problemas sociais, econômicos e políticos de uma nação afetam toda comunidade internacional, sendo que essa cooperação entre os países pelo direito ao desenvolvimento deve nortear todas as suas relações, em especial, as negociações no âmbito do comércio internacional de serviços educacionais.

Dessa forma, não podem prevalecer os princípios da lógica do mercado, do individualismo e do utilitarismo, vez que a prestação dos serviços educacionais deve visar, em primeiro lugar e acima de tudo, a plenitude do direito à educação como direito humano fundamental à realização do direito ao desenvolvimento.

No entanto, é possível notar que a inserção dos serviços educacionais no comércio internacional, com especial ênfase nas negociações no âmbito da OMC, se deu a partir do momento em que se verificou a possibilidade de torná-los negócios altamente lucrativos para as empresas privadas.

Assim, ao contrário do que determinam as regras e princípios internacionais sobre a realização do direito ao desenvolvimento, evidente que a preocupação dos negociadores comerciais não é, em primeiro lugar, tratar a educação como um bem público e um direito humano, mas sim evidenciar os melhores caminhos para o livre comércio como gerador de crescimento econômico. Por este motivo, o debate sobre o comércio de serviços educacionais deve ser encarado com a maior cautela possível, a fim de inverter os interesses envolvidos na questão.

Isso porque a liberalização do comércio de serviços educacionais não pode favorecer ou resultar na infração dos princípios e fundamentos do direito humano à educação e do direito ao desenvolvimento. Assim, não se pode cogitar a inclusão dos serviços educacionais no âmbito da $\mathrm{OMC}$, se não estiver garantido que estes serão vistos como direitos humanos e que, portanto, seus países Membros devem tratar a educação como um dos objetivos do direito ao desenvolvimento, antes de qualquer outro objetivo, especialmente, a busca pelo lucro.

${ }^{362}$ Arendt, 2005, p. 222. 
Ressalte-se que, ainda que cada vez mais as instituições privadas venham a realizar o papel inicialmente conferido ao Estado de prestar os serviços educacionais, elas também devem obedecer aos princípios estabelecidos pelo Direito Internacional dos Direitos Humanos, buscando oferecer serviços de melhor qualidade e facilitando o maior acesso à educação para todos.

No entanto, essa responsabilidade que recai sobre as instituições de ensino somente pode ser cobrada e fiscalizada pelos Estados e é preocupante notar que, apesar dessas obrigações, a mercantilização da educação já vem apresentando problemas lastimáveis. Neste sentido, Marco Antonio R. Dias cita um exemplo de propaganda de uma "instituição de ensino", que oferece diplomas - de bacharéis, mestres, doutores etc - para qualquer pessoa e em qualquer campo com base nos seus conhecimentos e experiências atuais, sem exigir o atendimento a qualquer curso, ou apresentação de trabalhos, ou a realização de entrevistas. Garantem ainda a confidencialidade das informações dos clientes e o envio do diploma em poucos dias ${ }^{363}$.

Como bem ressalta Maria Arleth Pereira ${ }^{364}$, essas obrigações dos Estados, indivíduos, da comunidade internacional e dos prestadores de serviços educacionais decorrem do fato de que: "a educação, dentro ou fora das escolas e das universidades, não pode exercer uma função de simples transmissão de informação, de técnicas e de conhecimentos utilitários, pautados no individualismo racional e desconectados da subjetividade".

A aprendizagem deve constituir, portanto, um processo social de pensamento crítico de confrontação e análise, não devendo apenas assumir um caráter técnico instrumental de duração rápida e descartável, podendo ser desenvolvida por qualquer empresa do ramo educacional.

E é nesse contexto que Agostinho dos Reis Monteiro destaca que:

Direito à educação não é direito apenas à disponibilidade e acessibilidade de uma educação qualquer, avaliada por indicadores meramente utilitários e quantitativos. É, por definição, direito à uma bem determinada qualidade de educação, a uma educação com qualidade ético-jurídica de direito do ser

\footnotetext{
${ }^{363}$ Dias, 2002, p. 16-17. O anúncio, publicado em inglês, diz: "Obtain a prosperous future, money earning, power and the admiration of all. Diplomas from prestigious non-credited universities based on your present knowledge and life experience. No required texts, classes, books or interviews. Bachelors, masters, MBA and doctorate $(P h D)$ diplomas. Available in the field of your choice. No one is turned down. Confidentiality assured. CALL NOW to receive your diplomas within days!!! Call 24 hours a day, 7 days a week, including Saturdays and Sundays".

${ }^{364}$ Pereira, 2007, p. 7.
} 
humano, isto é, cujas condições materiais, institucionais e pessoais respeitem todo o conteúdo normativo, devidamente interpretado, do direito à educação $^{365}$.

Assim, os objetivos primordiais do Estado e da comunidade internacional, mesmo inseridos na $\mathrm{OMC}$, deverão ser sempre direcionados à realização do direito à educação, por meio do maior acesso ao ensino e de melhorias constantes e progressivas na qualidade dos serviços educacionais prestados pela iniciativa pública e - principalmente - privada.

Nesse sentido, a Relatora Especial do Comitê sobre Direitos Econômicos, Sociais e Culturais questiona justamente se a inclusão dos serviços educacionais na OMC irá caminhar em direção à liberalização progressiva dos mercados ou à progressiva realização do direito à educação. Em resposta à sua própria indagação, entende que até o momento, o enfoque dado às negociações sobre o comércio de serviços educacionais na OMC tem atendido primordialmente aos interesses dos exportadores de serviços, colocando a educação como uma mercadoria internacional ${ }^{366}$.

Isso porque, como bem ressalta o professor Umberto Celli $\mathrm{Jr}^{367}$, apesar de os acordos da OMC conterem regras que concedem prerrogativas a países em desenvolvimento e que prevêem a proteção do espaço para políticas públicas desses países, na realidade prática, a Organização tem funcionado de modo inconsistente com o seu próprio mandato. Isso porque:

assegurar o pleno emprego e aumentar padrões de vida certamente não constituem referências ou padrões de avaliação dos países desenvolvidos quando pressionam a agenda das negociações na Rodada Doha. O sistema tem operado, portanto, com base na crença de que os princípios (neo) liberais serão de facto a melhor política de desenvolvimento para os PEDs, enquanto os próprios países desenvolvidos buscam o maior número possível de alternativas para proteger seus setores sensíveis.

Neste sentido, o professor ressalta que:

A recalibração das prioridades, dos valores e dos modos de funcionamento do sistema multilateral implicaria a efetiva inclusão de temas relacionados a questões sociais e de desenvolvimento, que não podem ser dissociados do objetivo de liberalização do comércio internacional. Essa recalibração é necessária como forma de corrigir ou, pelo menos, diminuir, o desequilíbrio operacional do sistema em favor dos países desenvolvidos.

\footnotetext{
${ }^{365}$ Monteiro, 2003, p. 786 e 787.

${ }^{366}$ E/CN.4/2002/60, parágrafos 20-21.

${ }^{367}$ Celli Jr., 2008(a), p. 122.
} 
Assim, já existem propostas que visam a combater a mercantilização da educação. O Alto Comissariado de Direitos Humanos da $\mathrm{ONU}^{368}$, por exemplo, identificou uma série de questões que necessitam maior atuação dos Estados, da comunidade internacional e dos próprios indivíduos e prestadores de serviços, em prol de um enfoque de direitos humanos sobre o comércio de serviços em geral, tais como: (i) a necessidade de garantir o acesso igualitário a todos os serviços básicos, como a educação, por meio de atitudes positivas pela eliminação do isolamento social e da pobreza; (ii) a necessidade de garantir o direito e o dever dos Estados de regulamentar o setor de serviços, utilizando-se efetivamente das provisões do GATS que prevêem essa prerrogativa a seus Membros; (iii) a necessidade de se encorajar a interpretação do GATS de acordo com o Direito Internacional dos Direitos Humanos e, mais do que isso, encorajar o tratamento dos direitos humanos como principal objetivo do GATS, como qualquer tratado internacional, em que os países signatários sejam membros da ONU; e (iv) a necessidade de se fomentar a cooperação e a assistência internacional, uma vez que todos os Estados são co-responsáveis pela realização dos direitos humanos em todos os territórios.

Por sua vez, a UNESCO, reconhecendo que a crescente exploração comercial dos muitos domínios antes considerados bens púbicos, tais como ensino, a cultura e a informação, põe em perigo os elementos da comunidade mundial mais fracos e privados de poder econômico, mas nem por isso menos importantes que outros, propõe-se a elaborar princípios e normas, fundados em valores comuns, para responder aos novos desafios nos domínios da educação, da ciência, da cultura e da comunicação e para preservar e consolidar o bem público comum. Para tanto, guia-se por três princípios essenciais e indissociáveis: universalidade, diversidade e dignidade.

É bem verdade que a educação por si só não é suficiente para mudar o destino do mundo, porém, é um instrumento essencial que pode ser transformado num mecanismo político pedagógico importante no direcionamento de uma cultura contra-hegemônica do modo de viver da sociedade do nosso tempo. Nesse sentido, a construção histórica da educação deve ser concebida a partir de uma visão de possibilidades emancipatórias e não apenas pela ótica do determinismo que concebe a educação como instrumento intocável do aparelho ideológico do capitalismo internacional $^{369}$.

\footnotetext{
${ }^{368}$ E/CN.4/Sub.2/2002/9, p. 5.

${ }^{369}$ Pereira, 2007, p. 8.
} 
É preciso, portanto, fazer avançar o processo de reflexão e de ação que conduz o desenvolvimento de uma mudança educacional que regulamenta de fato o direito à educação de qualidade social e cultural, em todos os níveis de escolaridade ${ }^{370}$.

E somente este entendimento pode permitir que a educação alcance seus objetivos que, segundo Hannah Arendt ${ }^{371}$ consistem na preparação para a introdução do jovem no mundo. Somente a educação concede a base necessária para a formação de adultos políticos, que poderão atuar na política arendtiana.

Com base nesse entendimento, a educação assume papel fundamental para o Estado, já que é ela que prepara o indivíduo para atuar como cidadão de uma nação, que caracteriza-se como um dos aspectos do direito ao desenvolvimento. Em outras palavras, o acesso à educação de qualidade é condição para a eliminação de privações da liberdade dos homens, permitindo que eles estejam capacitados a exercer efetivamente seus direitos e liberdades fundamentais como cidadãos. Assim, as negociações internacionais sobre o comércio de serviços educacionais sempre envolverão questões delicadas, que tocam, inclusive, a formação humana e democrática da população de um país.

Diante de todo exposto, como indica Gustavo Ferreira Ribeiro ${ }^{372}$, existem duas grandes correntes sobre a relação entre o direito humano à educação e o GATS. A corrente "liberal" defende que os benefícios decorrentes da liberalização são aplicáveis a qualquer serviço, independentemente da sua natureza, vez que entende que o livre mercado proporciona a modernização dos serviços, a queda de preços, o acesso a novas tecnologias etc., sendo que o livre comércio é suficiente para resolver os problemas econômicos, sociais, culturais e políticos do mundo.

Por outro lado, uma segunda corrente entende que as vantagens da liberalização em relação a serviços como a educação devem ser analisados por outros ângulos, a partir do momento que a educação é um direito humano e demanda responsabilidades do Estado.

Este entendimento, com o qual se coaduna o presente trabalho, não pretende levantar bandeiras contra o comércio internacional, proclamando-se o fechamento dos mercados e o isolamento dos países, mas insiste sim na importância de se estabelecer prioridades no âmbito das relações internacionais.

\footnotetext{
${ }^{370}$ Pereira, 2007, p. 9.

${ }^{371}$ Arendt, 2005, p. 221-247.

372 Ribeiro, 2004, p. 132.
} 
Assim, por todos os argumentos apresentados nesta ocasião, que demonstram que o mero crescimento econômico não traz os verdadeiros benefícios do desenvolvimento e não colabora para o alcance da verdadeira paz social internacional, é evidente que as vantagens econômicas do comércio internacional de serviços educacionais não são a prioridade do momento.

Não há dúvidas de que, diante do gritante cenário de desigualdades avassaladoras, o objetivo primordial da comunidade internacional, dos Estados, dos indivíduos, do Direito Internacional e do comércio internacional deve - e só poderia - ser o direito ao desenvolvimento, uma vez que ele corrobora todas as lutas pelos direitos humanos e pela paz.

Logo, se as regras do comércio internacional de serviços educacionais não estiverem de acordo com as prioridades que norteiam todo o cenário internacional, evidente que não se pode corroborá-las. É necessário, portanto, que toda e qualquer intenção, proposta ou compromisso no setor de serviços educacionais na OMC esteja, em primeiro lugar, voltado à realização do direito ao desenvolvimento. Só assim será possível alcançar relações econômicas justas.

E a justiça nas relações internacionais deverá estar sempre ligada à busca de maior igualdade entre os países, de maior justiça social internamente e respeito universal aos direitos humanos. Somente com vistas a esses valores é que será possível alcançar a paz positiva como justiça, uma vez que a paz internacional atualmente não pode ser dissociada desses valores, não correspondendo apenas à ausência de guerra. 


\section{BIBLIOGRAFIA}

ABI-SAAB, Georges. The Legal Formulation of s Right to Development (Subject and Content). In: The Right to Development at the International Level. Haia, 1979, pp. 159175.

ALMEIDA, Paulo Roberto de. O fim de Bretton-Woods?: a longa marcha da Organização Mundial do Comércio. In Contexto Internacional, vol. 16, n. 2, julho-dezembro de 1994, pp. 249-282.

- A globalização e o desenvolvimento: vantagens e desvantagens de um processo indomável. In: CHEREM, Mônica Teresa e DI SENA JR., Roberto (org.). Comércio internacional e desenvolvimento: uma perspectiva brasileira. São Paulo: Saraiva, 2004, pp. 17-31.

ALSTON, Philip. The right to development at the international level. In SNYDER, Frederick. E., SATHIRATHAI, Surakiart. (eds.). Third world attitudes towards international law: an introduction. Dordrecht: Martinus Nijoff Publishers, 1987, pp. 811-823.

AMARAL Jr, Alberto do. A OMC e o comércio internacional. São Paulo: Aduaneiras, 2002.

- A institucionalização internacional dos direitos humanos: conquistas e desafios. In: PIOVESAN, Flávia (org.), Direitos humanos, globalização econômica e integração regional - desafios do direito constitucional internacional. São Paulo: Max Limonad, 2002.

ARENDT, Hannah. A Condição Humana. Rio de Janeiro: Forense Universitária, 1995.

Origens do Totalitarismo: anti-semitismo, imperialismo, totalitarismo. São Paulo: Cia. das Letras, 2000.

. A Crise na Educação. In: ARENDT, Hannah. Entre o passado e o futuro. São Paulo: Perspectiva, 2005, pp. 221-247. 
. Reflexões sobre Little Rock. In: ARENDT, Hannah. Responsabilidade e julgamento. São Paulo: Companhia das Letras, 2004, pp. 261-281.

BANCO MUNDIAL. Financing education in developing countries: an exploration of policy options. Washington, 1986.

BAPTISTA, Luiz Olavo, HUCK, Hermes Marcelo, CASELLA, Paulo Borba (orgs.). Direito e comércio internacional: tendências e perspectivas: estudos em homenagem ao Professor Irineu Strenger. São Paulo: LTR, 1994.

BARRAL, Welber. A influência do comércio internacional no processo de desenvolvimento. In: BARRAL, Welber e PIMENTEL, Luiz Otávio (coord.). Comércio Internacional e Desenvolvimento, Florianópolis: Boiteux, 2006, pp. 11-35.

. Direito e desenvolvimento: um modelo de análise. In: BARRAL, Welber (org.). Direito e desenvolvimento: análise da ordem jurídica brasileira sob a ótica do desenvolvimento. São Paulo: Singular, 2005, pp. 31-60.

. Desenvolvimento na Rodada Doha da OMC. In: CHEREM, Mônica Teresa e DI SENA JR., Roberto (org.). Comércio internacional e desenvolvimento: uma perspectiva brasileira. São Paulo: Saraiva, 2004, pp. 125-141.

BARRETT, B.F.D. Higher Ed. and the Info Soc. In: Informal Event at the WSIS Prep. Comm. II. Geneva, United Nations University - UNU, 27 Feb. 2003. Disponível em: <http://www.gvu.unu.edu/docs/WSIS\%202-3-3.ppt>.

BATISTA, Paulo Nogueira. O Consenso de Washington: a visão neoliberal dos problemas latino-americanos. São Paulo: Paz e Terra, 1994.

BEDJAOUI, Mohammed. Some Unorthodox Reflections on the 'Right to Development'. In SNYDER, F., e SLINN, P. (orgs). International Law of Development: Comparative Perspectives. Oxon: Professional Books, 1987.

. The Right to Development. In: BEDJAOUI, Mohammed (ed.). International Law: Achievements and Prospects. Dordrecht: Martinus Nijhoff Publishers, 1991, pp. 11771203.

. Right to development and the ius cogens. In: BULAJIC, Milan; MARINKOVIC, Mormika e PINDIC, Dimitieje. The Charter of Economic Rights and Duties of States - 
Ten Years of Implementation, The Proceedungs of the First Yugoslav International Seminar on Legal Aspects of the NIEO, Beograd, 11-13 April 1985. Beograd: Institute of International Politics and Economy, 1985, p. 48-55.

BENNOUNA, Mohamed. Droit international du développement: tiers monde et interpellation du droit international. Paris: Bérger-Levraut, 1983.

BOBBIO, Norberto. A era dos direitos. Rio de Janeiro: Elsevier, 2004.

BORGES, Karla Cristina Martins. O GATS, seu artigo IV, o processo de liberalização e o incremento da participação do Brasil no comércio internacional. In: CELLI JR., Umberto e SAYEG, Fernanda Manzano (coords.). Comércio de Serviços, OMC e Desenvolvimento. São Paulo: IDCID, 2008, pp. 19-41.

BOTTO, Mercedes e BATISTA, Juliana Peixoto. La incidencia de La academia em lãs negociaciones de los servicios de salud y educación en la Argentina: desafios y oportunidades. In: BOTTO, Mercedes (coord.). Saber y Política en América Latina. Buenos Aires: Prometeo Libros, 2007, p. 247-291.

BRASIL. Constituição (1988). Constituição da República Federativa do Brasil, de 5 de outubro de 1988, 37ª Ed. São Paulo: Saraiva, 2005.

_. Decreto $n .^{\circ} 1.355$, de 30 de dezembro de 1994. Promulga a Ata Final que Incorpora os Resultados da Rodada Uruguai de Negociações Comerciais Multilaterais do GATT. Disponível em: <www.planalto.gov.br>.

- Lei $n .^{\circ}$ 9.394, de 20 de dezembro de 1996. Estabelece as diretrizes e bases da educação nacional. Disponível em: <www.planalto.gov.br>.

Decreto $n .^{\circ}$ 2.207, de 15 de abril de 1997. Regulamenta, para o Sistema Federal de Ensino, as disposições contidas nos arts. 19, 20, 45, 46 e $\S 1^{\circ}$, 52, parágrafo único, 54 e 88 da Lei $n^{\circ}$ 9.394, de 20 de dezembro de 1996, e dá outras providências. Disponível em: <www.planalto.gov.br>.

. Decreto $n .^{\circ}$ 2.306, de 19 de agosto de 1997. Regulamenta, para o Sistema Federal de Ensino, as disposições contidas no art. 10 da Medida Provisória $\mathrm{n}^{\circ}$ 1.477-39, de 8 de agosto de 1997, e nos arts. 16,19, 20, 45, 46 e $\S 1^{\circ}, 52$, parágrafo único, 54 e 88 da Lei 
n 9.394, de 20 de dezembro de 1996, e dá outras providências. Disponível em: $<w w w \cdot p l a n a l t o . g o v \cdot b r>$.

. Decreto $n .^{\circ} 3.276$, de 6 de dezembro de 1999. Dispõe sobre a formação em nível superior de professores para atuar na educação básica, e dá outras providências. Disponível em: <www.planalto.gov.br>.

_. Decreto $n .^{\circ} 10.172$, de 9 de janeiro de 2001. Dispõe sobre a organização do ensino superior, a avaliação de cursos e instituições, e dá outras providências. Disponível em: $<w w w . p l a n a l t o . g o v \cdot b r>$.

_. Decreto $n .^{\circ} 3.860$, de 9 de julho de 2001. Aprova o Plano Nacional de Educação e dá outras providências. Disponível em: <www.planalto.gov.br>.

BULAJIC, Milan. Principle of International Development Law: Progressive Development of Principle of International Law relating to the New International Economic Order. London: Martinees Nighoff, 1993.

CARREAU, Dominique, e JUILLARD, Patrick. Droit International Économique, $4^{\mathrm{a}}$ Ed. Paris: LGDJ, 1998.

CASTELLS, Manuel. The university system: engine of development in the new world economy. In: SALLY, Jamil; VERSPOOR, Adriaan M. Revitalizing higher education. Oxford: IAU, 1994.

CELLI JR., Umberto. O caso Telmex e os países em desenvolvimento. In: CELLI JR., Umberto (coord.). Comércio de serviços na OMC. Curitiba: Juruá, 2005.

. Os acordos de serviços (GATS) e de investimentos (TRIMS) na OMC: espaço para políticas de desenvolvimento. In: BARRAL, Welber e PIMENTEL, Luiz Otávio (coord.). Comércio Internacional e Desenvolvimento, Florianópolis: Boiteux, 2006, pp. $37-52$.

- Liberalização do comércio de serviços na OMC: condições e desafios. (Tese de livre docência). Faculdade de Direito da Universidade de São Paulo. São Paulo, 2008(a).

- Serviços educacionais no GATS: desafios para o Brasil. In: Pontes entre o Comércio e o Desenvolvimento Sustentável, vol. 4, $\mathrm{n}^{\circ}$ 4, ago. 2008(b). Disponível: $<$ http://ictsd.net/news/pontes/?volume=4\&number $=4>$. 
CHEREM, Mônica Teresa. Muito além da utopia: o direito ao desenvolvimento na perspectiva da globalização. In: CHEREM, Mônica Teresa e DI SENA JR., Roberto (org.). Comércio internacional e desenvolvimento: uma perspectiva brasileira. São Paulo: Saraiva, 2004, pp. 93-105.

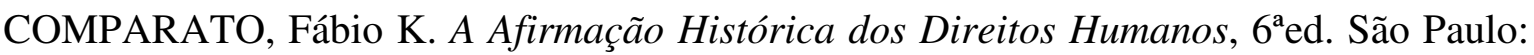
Saraiva, 2008.

O reconhecimento de direitos coletivos na esfera internacional. In: BAPTISTA, Luiz Olavo e FONSECA, José Franco da (coord.). O direito internacional no terceiro milênio: estudos em homenagem ao Professor Vicente Marotta Rangel. São Paulo: LTr, 1998, p. 643-652.

CONFERENCIA MUNDIAL PELOS DIREITOS HUMANOS. Declaração e Programa de Ação de Viena. 25 jun. 1993. Disponível em: $<$ http://www2.ohchr.org/english/law/pdf/vienna.pdf>.

COOMANS, Fons. Core elements of the right to education. In: SIM Special, $\mathrm{n}^{\mathrm{o}} 18$. Utrecht: Utrecht University, 1995. Disponível em: <http://www.uu.nl/uupublish/content/SIMSpecial18-03.pdf>.

CUNHA, Ciro Leal M. da. A introdução do comércio de serviços na regulação multilateral do comércio - breve histórico. In: CELLI JR., Umberto (coord.). Comércio de serviços na OMC. Curitiba: Juruá, 2005, p. 17-41.

DALLARI, Dalmo de Abreu. ALCA e o comércio de serviços. In Juízes para a democracia, São Paulo, v. 6, n. 31, p. 6-7, jan./mar, 2003. Disponível em: $<$ http://www.asc-hsa.org/pdf/Servicios\%20DALMO\%20Dallari.pdf>.

DAUDET, Yves. Les Nations Unies et le Développement Social Internacional-Colloque: 16 et 17 février 1996. Paris: Pedone, 1996.

DELANY, Paul. Where Did You Say You Were? In: Virtual Universities and the Death of Distance.1996. Disponível em: <http://www.sfu.ca/delany/mla96/delany.html>.

DI DIO, Renato Alberto Teodoro. Contribuição à Sistematização do Direito Educacional. Taubaté: Universitária, 1982. 
DI SENA JR. Roberto. Crescimento econômico e desigualdade à luz do comércio internacional. In: CHEREM, Mônica Teresa e DI SENA JR., Roberto (org.). Comércio internacional e desenvolvimento: uma perspectiva brasileira. São Paulo: Saraiva, 2004, pp. 58-71.

DIAS, Marco Antonio Rodrigues. Comercialização no ensino superior: é possível manter a idéia de bem público? In: Educação Social, vol. 24, n 84, setembro de 2003, pp. 817838.

. Educação superior: bem público ou serviço comercial regulamentado pela OMC? In: II Reunião de Reitores de Universidades Públicas Ibero-Americanas, Porto Alegre, 26 abr. 2002.

DOMMEN, Caroline. Comércio e direitos humanos: rumo à coerência. In: SUR - Reviste Internacional de Direitos Humanos, ano 2, n $3,1^{\circ}$ semestre de 2005.

DUARTE, Clarice Seixas. A educação como um direito fundamental de natureza social. In: Educação Social, vol. 28, no 100 - Especial, outubro de 2007, p. 691-713. Disponível em: <http://www.cedes.unicamp.br>.

ESPIELL, Héctor Gros. The right to development as a human right. In Texas International Law Journal, v. 16, n. 2, University of Texas, School of Law, 1981.

FARIA, José Eduardo. O future dos direitos humanos após a globalização econômica. In: AMARAL Jr., Alberto do, e PERRONE-MOISÉS, Cláudia (orgs). O Cinqüentenário da Declaração Universal dos Direitos do Homem. São Paulo: Edusp/Fapesp, 1999, pp. $55-74$.

FLORY, Maurice. Droit international du développement. Paris: Presses Universitaires de France, 1977.

FLUER, Guy. Les principes fondamentaux dans le droit international du développement. SFDI, Coloque d'Áix en Provence. Paris: Pedone, 1997.

, e CASSAN, Hervé. Droit international du développement. Paris: Dalloz, 1991.

FOLHA DE SÃO PAULO. Estrangeiro ganha espaço no ensino superior brasileiro. 27 jul. $2008 . \quad$ Disponível em:

<http://www1.folha.uol.com.br/folha/educacao/ult305u426660.shtml>. 
. Grupo dos EUA compra a Anhembi Morumbi. 02 dez. 2005. Disponível em: <http://www1.folha.uol.com.br/folha/educacao/ult305u18114.shtml>.

_. Universidade paga não segue lei de professor exclusivo. 12 mai. 2008. Disponível em: <http://www1.folha.uol.com.br/fsp/cotidian/ff1205200801.htm>.

_. Escolas afirmam que percentuais têm aumentado. 20 mai. 2008. Disponível em: <http://www1.folha.uol.com.br/fsp/cotidian/ff1205200802.htm>.

HADDAD, Sérgio e GRACIANO, Mariângela. Educação: direito universal ou mercado em expansão. In: São Paulo em Perspectiva, vol. 18, n. 3, 2004, pp. 67-77.

HALVORSEN, Kate. Notes on the realization of the human right to education. In: Human Rights Quarterly, vol. 12, 1990, pp. 341-364.

HESSE, Konrad. Elementos de Direito Constitucional da República Federal da Alemanha. Porto Alegre: Fabris, 1998.

HODGSON, Douglas. The international human right to education and education concerning human rights. In: The international Journal of Children's Rights, nº4, 1996, pp. 237-262.

\section{INSTITTUTO NACIONAL DE ESTUDOS E PESQUISAS EDUCACIONAIS ANÍSIO} TEIXEIRA (INEP). Sistema de Estatísticas Educacionais, 2004. Disponível em: $<\mathrm{http}: / /$ www.edudatabrasil.inep.gov.br/index.htm>.

ISA, Felipe Gómez. El derecho al desarollo: entre la justicia y la solidaridad. In Cuadernos Deusto de Derechos Humanos, n. 1, Bilbao: Instituto de Derechos Humanos, Universidad de Deusto, 1998.

ISTOÉ DINHEIRO. São Paulo, 21 fev. 2003. Disponível em: $<$ http://www.terra.com.br/istoedinheiro/286/negocios/286_ensino.htm>.

JENKS, Wilfred. The Five economic and social rights. In: Annals of the American Academy of Political and Social Science, vol. 243, Essential Human Rights, janeiro de 1946, p. 40-46.

KANT, Immanuel. A paz perpétua e outros opúsculos. Trad. Artur Mourão. Lisboa: 70, 2002. 
KAUL, Inge; GRUNBER, Isabelle e STERN, Marc A. Executive Summary. In: KAUL, Inge; GRUNBER, Isabelle e STERN, Marc A (orgs.). Global Public Goods: International Cooperation in the 21st Century. Oxford: Oxford University Press, 1999, p. 308-326.

KEYNES, John Maynard. A teoria geral do emprego, do juro e da moeda. São Paulo: Nova Cultural, 1996.

KNIGHT, Jane. GATS, Trade and Higher Education: Perspective 2003 - where are we?. In: The observatory on borderless higher education, maio de 2003. Disponível em: $<$ http://www.obhe.ac.uk/home>.

LAFER, Celso. Resistência e Realizabilidade da Tutela dos Direitos Humanos no PlCiano Internacional no Limiar do Século XXI. In: AMARAL Jr., Alberto do, e PERRONEMOISÉS, Cláudia (orgs). O Cinqüentenário da Declaração Universal dos Direitos do Homem. São Paulo: Edusp/Fapesp, 1999, p.441-52.

. A Reconstrução dos Direitos Humanos - Um diálogo com o Pensamento de Hannah Arendt. São Paulo: Companhia das Letras, 2003.

_ Comércio, desarmamento, direitos humanos: reflexões sobre uma experiência diplomática. São Paulo: Paz e Terra, 1999.

A Internacionalização dos direitos humanos: Constituição, racismo e relações internacionais. São Paulo: Manole, 2005.

Lamy announces "soft" re-launch of WTO talks. In: TradEducation News, vol. 12, dezembro de 2006. Disponível em: <http://data.eiie.org/docs/1/EPFDMOBBLNCJEGGAAGLLIIEGPDBN9DB6PG9DW3571KM/educ ation/docs/DLS/2006-00329-01-E.pdf>.

LARSEN, Kurt; MARTIN, John P. e MORRIS, Rosemary. Trading in education services: trends and the emerging issues. OCDE, 2002. Disponível em: <www.oecd.org>.

L'education, une bonne affaire. In: La lettre de l'EIP, n³3, setembro de 2006. Disponível em: <http://www.eip-cifedhop.org/lettre/archives/Lettre33/lettre33.html>.

LIBERATI, Wilson Donizeti (coord.). Direito à educação: uma questão de justiça. São Paulo: Malheiros, 2004. 
MACHADO JR., César Pereira da Silva. $O$ direito à educação na realidade brasileira. São Paulo: LTr, 2003.

MAJID, Nomaan. Globalization and poverty. Genebra: Organização Internacional do Trabalho, 2003. Disponível em: $<$ http://www.ilo.org/public/english/employment/strat/download/ep54.pdf $>$. Acesso em: 02 dez 2008.

MALHOTRA, Rajeev. Right to development: where are we today?. In: SENGUPTA, Arjun; NEGI, Archna e BASU, Moushumi (eds.). Reflections on the right to development. Nova Delhi: Centre for Development and Human Rights, Sage Publications, 2005, pp. 127-154.

MARKS, Stephen P. The human rights framework for development: seven approaches. In: SENGUPTA, Arjun; NEGI, Archna e BASU, Moushumi (eds.). Reflections on the right to development. Nova Delhi: Centre for Development and Human Rights, Sage Publications, 2005, pp. 23-60.

MASTAGLIA, Gabriela Teresita. Globalización y desarollo: su impacto em El âmbito de los derechos humanos. In: BARRAL, Welber e CORREA, Carlos (org.). Derecho, desarollo y sistema multilateral del comercio. Florianópolis: Boiteux, 2007, pp. 103133.

M’BAYE, Keba. Le Droit au Développement comme un Droit de 1'Homme. In Revue des Droits de l'Homme, vol V, n. 2-3, 1972, pp. 502-525.

Introduction. In: BEDJAOUI, Mohammed (ed.). International Law: Achievements and Prospects. Paris: UNESCO; Martinus Nijhoff Publishers, 1991, pp. 1041-1058.

MELLO, Celso D. de Albuquerque. Direito Internacional Econômico. Rio de Janeiro: Renovar, 1993.

MERCADANTE, Araminta de Azevedo. Acordo Geral sobre o comércio de serviços: aspectos jurídicos. In: CASELLA, Paulo Borba e MERCADANTE, Araminta de Azevedo (coord.). Guerra comercial ou integração mundial pelo comércio? A OMC e o Brasil. São Paulo: LTr, 1998. 
MERLOZ, Georges. La CNUCED: droit international et développement. Bruxelas: Bruylant, 1980.

MERRILL, L. Stimulating Investment in Global Education, EdInvest, NCSPE (National Center for the Study of Privatization in Education, Columbia University, EUA). [s.d.]. Disponível em: $<$ http://www.ncspe.org/publications_files/EDinvest\%20Columbia\%202003.ppt>.

MONTEIRO, Agostinho dos Reis. O pão do direito à educação... In: Educação Social, vol. 24, nº 84 , setembro de 2003, pp. 763-789.

MUNHOZ, Carolina Pancotto Bohrer. A evolução histórica do conceito de desenvolvimento. In: CHEREM, Mônica Teresa e DI SENA JR., Roberto (org.). Comércio internacional e desenvolvimento: uma perspectiva brasileira. São Paulo: Saraiva, 2004, pp. 1-16.

MUSGRAVE, Richard A. The theory of public finance. Nova Iorque: McGraw-Hill, 1959.

NASSER, Rabih Ali. O sistema multilateral de comércio e as restrições à liberdade de desenvolvimento - subsídios e TRIMs na OMC, dissertação de doutorado apresentada na Faculdade de Direito da USP, 2002.

. A OMC e os países em desenvolvimento. São Paulo: Aduaneiras, 2002.

NORTH, Douglas C. Instituciones, cambio institucional y desempeño económico. México: Fondo de Cultura Económica, 2001.

OKAFOR, Obiora Chinedu. The status and effect of the right to development in contemporary international law: towards a south-north "entente". In: African Journal of International and Comparative Law, dezembro de 1995, v. 7, n. 4, pp. 865-867, 881885.

OLIVEIRA, Silvia Menicucci de. Barreiras Não Tarifarias no Comércio Internacional e Direito ao Desenvolvimento. São Paulo: Renovar, 2005.

Direito ao desenvolvimento na perspectiva da Conferência das Nações Unidas para Comércio e Desenvolvimento - CNUCED. In MERCADANTE, Araminta de Azevedo e MAGALHÃES, José Carlos de (coords.). Solução e prevenção de litígios internacionais, vol. III. Rio de Janeiro: Forense, 2003. 
. Direito ao desenvolvimento: teorias e estratégias de implementação. São Paulo, 2006, 322 p. - Tese de Doutorado apresentada no Departamento de Direito Internacional da Faculdade de Direito da Universidade de São Paulo.

- Financiamento internacional do desenvolvimento: seu papel na implementação do direito ao desenvolvimento. In: AMARAL Jr, Alberto do. Direito Internacional $e$ desenvolvimento. Barueri: Manole, 2005, p. 219-253.

OCDE. Trade in Educational Services: what can we learn from existing data?. Background note by OECD Secretariat. Junho de 2001. Disponível em: $<$ www.oecd.org $>$.

ORGANIZAÇÃO MUNDIAL DO COMÉRCIO. Conselho sobre Comércio de Serviços. Education services: background Note by the Secretariat. 23 de setembro de 1998 (S/CSS/W/59). Disponível em: <www.docsonline.wto.org>.

_. Guide to the GATS - An overview of issues for further liberalization of trade in services, 2000. Documento editado pelo Secretariado da OMC. Disponível em: $<$ www.docsonline.wto.org $>$.

_.. GATS facts and fiction. Genebra: 2001.

_. Services sectoral classification list, 10 Jul. 1991 (MTN.GNS/W/120). Disponível em: $<$ www.docsonline.wto.org $>$.

. Communication from the United States: education services, 20 out. 1998 (S/C/W/55). Disponível em: <www.docsonline.wto.org>.

. Communication from New Zealand: negotiating proposal for education services, 26 jun. 2001 (S/C/W/93). Disponível em: <www.docsonline.wto.org>.

_. Communication from Australia: negotiating proposal for education services, 01 out. 2001 (S/C/W/110). Disponível em: <www.docsonline.wto.org>.

_. Communication from Japan: negotiating proposal for education services, 12 mar. 2002 (S/C/W/137). Disponível em: <www.docsonline.wto.org>. 
. Communication from Switzerland: Education Services and the GATS: the experience of Switzerland, 04 abr. 2005 (TN/S/W/39). Disponível em: $<$ www.docsonline.wto.org $>$.

. Acordo Constitutivo da Organização Mundial do Comércio. Marraqueche, 15 abr. 1994. Decreto n. ${ }^{\circ}$ 1.355/94, publicado no D.O.U. de 31/12/94. Disponível em: $<$ www.planalto.gov.br>.

. Acordo Geral sobre o Comércio de Serviços (GATS). Marraqueche, 15 abr. 1994. Decreto n. ${ }^{\circ}$ 1.355/94 publicado no D.O.U. de 31/12/94. Disponível em: $<$ www.planalto.gov.br>.

ORGANIZAÇÃO DAS NAÇÕES UNIDAS, A Declaração sobre o Direito ao Desenvolvimento. Res. 41/128 da Assembléia Geral das Nações Unidas em 04 dez. 1986. Disponível em: <http://www.un.org/Depts/dhl/>.

—. Divisão de Estatísticas. Central Product Classification V 1.1.ST/ESA/STAT/SER.M/77/Ver.1.1. 2002. Disponível em: <www.unstats.un.org>. - ECOSOC, Alto Comissariado de Direitos Humanos. Liberalization of trade in services and human rights, junho de 2002 (E/CN.4/Sub.2/2002/9). Disponível em: $<$ http://www.un.org/Depts/dhl/>.

- Comissão de Direitos Humanos. Relatório do perito independente sobre direito ao desenvolvimento, Arjun Sengupta. The right to development, 11 set. 2000 (E/CN.4/2000/WG.18/CRP.1). Disponível em: <http://www.un.org/Depts/dhl/>.

- Comitê sobre Direitos Econômicos, Sociais e Culturais. Genneral Comment $n^{o} 13$ : The right to education (Article 13 of the Covenant), 8 dez. 1999 (E/C.12/1999/10). Disponível em: <http://www.un.org/Depts/dhl/>.

_. Comitê sobre Direitos Econômicos, Sociais e Culturais. Annual report of the Special Rapporteur on the right to education, Katarina Tomasevski, 7 jan. 2002 (E/CN.4/2002/60). Disponível em: <http://www.un.org/Depts/dhl/>.

. Carta das Nações Unidas. Conferência de São Francisco. 26 Jun. 1945. Disponível em: <http://www.un.org/Depts/dhl/>. 
. Declaração Universal dos Direitos Humanos. Res. 217 A (III) da Assembléia Geral das Nações Unidas em 10 Dez. 1948. Disponível em: <http://www.un.org/Depts/dhl/>.

_. Pacto Internacional dos Direitos Civis e Políticos. Res. 2.200-A (XXI) da Assembléia Geral das Nações Unidas em 16 Dez. 1966. Disponível em: <http://www.un.org/Depts/dhl/>.

_. Pacto Internacional dos Direitos Econômicos, Sociais e Culturais. Res. 2.200-A (XXI) da Assembléia Geral das Nações Unidas em 16 Dez 1966. Disponível em: $<$ http://www.un.org/Depts/dhl/>.

—. Relatório do Secretário-Geral. The international dimensions of the right to development as a human right in relation with other human rights based on international cooperation, including the right to peace, taking into account the requirements of the New International Economic Order and the fundamental human needs, Janeiro de 1979 (E/CN.4/1334). Disponível em: $<$ http://www.un.org/Depts/dhl/>.

PAIVA, Vanilda Pereira. Educação popular e educação de adultos. $5^{\mathrm{a}}$ Ed. São Paulo: Loyola, 1987.

PAJARA, F. As multinacionais do ensino. IstoÉ Dinheiro, 21 jan. 2003. Disponível em: $<$ http://www.terra.com.br/istoedinheiro/286/negocios/286_ensino.htm>.

PANAGARIYA, Arvind. Think again. Disponível em: <www.foreign policy.com>.

PERRONE-MOISÉS, Cláudia. Direitos Humanos e Desenvolvimento: A Contribuição das Nações Unidas. In: AMARAL Jr., Alberto do, e PERRONE-MOISÉS, Cláudia (orgs). O Cinqüentenário da Declaração Universal dos Direitos do Homem. São Paulo: Edusp/Fapesp, 1999, pp.179-96.

. Direito ao Desenvolvimento e Investimentos Estrangeiros. São Paulo: Oliveira Mendes, 1998.

. Tolerância, desenvolvimento e direitos humanos. In MERCADANTE, Araminta de Azevedo, e MAGALHÃES, José Carlos de (orgs.). Reflexões sobre os 60 anos da ONU. Ijuí: UNIJUÍ, 2005, pp. 240-249.

PELLET, Alain. Le droit international du développement. Paris: PUF, 1987. 
PEREIRA, Maria Arleth. Impacto da cultura de mercado na educação. In: Revista Iberoamericana de Educación, nº 42/6, 10 mai. 2007, p. 1-10.

PETERSMANN, Ernst-Ultrich. Human rights and international economic law in the 21ST Century - The need to clarify their interrelationships. In J. of International Economic Law, Oxford University, 2001, pp. 3-39.

PIOVESAN, Flávia. Direitos humanos e o direito constitucional internacional, $3^{\text {a }}$ Ed. São Paulo: Max Limonad, 1997.

_. Direitos sociais, econômicos e culturais e direitos civis e políticos. In: SUR - Revista Internacional de Direitos Humanos, ano 1, $\mathrm{n}^{\circ}$ 1, $1^{\circ}$ semestre de 2004, pp. 21-47.

PORTAL EXAME. Americanos oferecem R\$ 2,5 bilhões pelo Objetivo. 18 jun. 2008.

Disponível em: <http://portalexame.abril.uol.com.br/negocios/m0162280.html>.

PRAZERES, Tatiana Lacerda. Comércio internacional e desenvolvimento nas regras da OMC sobre investimentos (TRIMs). In: CHEREM, Mônica Teresa e DI SENA JR., Roberto (org.). Comércio internacional e desenvolvimento: uma perspectiva brasileira. São Paulo: Saraiva, 2004, pp. 142-155.

PRIMO, Etiane. Negociação e liberalização dos serviços educacionais. In: CELLI JR., Umberto (coord.). Comércio de serviços na OMC. Curitiba: Juruá, 2005, pp. 289-305.

PROGRAMA DAS NAÇÕES UNIDAS PARA O DESENVOLVIMENTO. Relatório de Desenvolvimento Humano, $1999 . \quad$ Disponível <http://hdr.undp.org/en/media/HDR_1999_EN.pdf>.

PRONER, Carol. Comércio de serviços. In BARRAL, Welber (org.), O Brasil e a OMC, $2^{\mathrm{a}}$ ed., $2^{a}$ tiragem. Curitiba: Juruá, 2003.

PUPO, Rodrigo Luís. Acordo Geral sobre o Comércio de Serviços - GATS. In: CELLI JR., Umberto (coord.). Comércio de serviços na OMC. Curitiba: Juruá, 2005, pp. 4372.

RAMOS, André de Carvalho. Teoria Geral dos Direitos Humanos na Ordem Internacional. Rio de Janeiro: Renovar, 2005. 
RANIERI, Nina Beatriz. Educação Superior, Direito e Estado: na Lei de Diretrizes e Bases (Lei no 9.394/96). São Paulo: Edusp/Fapesp, 2000.

. Direitos humanos e comércio internacional. A tutela do direito à educação nas negociações internacionais. In: YARSHELL, Flávio Luiz e MORAES, Maurício Zanoide. Estudos em homenagem à Professora Ada Pellegrini Grinover, $1^{\text {a }}$ Ed. São Paulo: DPJ Editora, 2005, pp. 58-70.

REDE BRASILEIRA PELA INTEGRAÇÃO DOS POVOS (REBRIP). Negociações de serviços na OMC: riscos do aprofundamento da abertura para o Brasil. Rio de Janeiro: REBRIP, 2006.

REIS, Henrique Marcello dos. Relações econômicas internacionais e direitos humanos. São Paulo: Quartier Latin, 2005.

RIBEIRO, Gustavo Ferreira. Comercio de servicios. In: BARRAL, Welber (org.). Negociaciones comerciales multilatrales. Córdoba: Editorial Mediterránea, 2006, pp. 107-120.

—. Educação superior e desenvolvimento. In: BARRAL, Welber (org.). Direito $e$ desenvolvimento: análise da ordem jurídica brasileira sob a ótica do desenvolvimento. São Paulo: Singular, 2005, pp. 321-340.

. Afinal, o que a organização mundial do comércio tem a ver com a educação superior?. In: Revista Brasileira de Política Internacional, vol. 49, nº 2, Brasília, jul/dez. 2006.

RICARDO, David. Princípios de economia política e tributação. São Paulo: Abril, 1978.

RICUPERO, Rubens. O Brasil e o dilema da globalização. $2^{\mathrm{a}}$ Ed. São Paulo: SENAC, 2001.

RISTER, Carla Abrantkoski. Direito ao desenvolvimento: antecedentes, significados e conseqüências, tese de doutorado, São Paulo: Faculdade de Direito da USP, 2003.

RODRIK, Dani. Growth strategies. Cambridge MA: John F. Kannedy School of Government, 2003.

SACHS, Ignacy. O Desenvolvimento enquanto apropriação dos Direitos Humanos. In: Estudos Avançados, v.12, n.33, mai-ago/1998. 
- Em busca de Novas Estratégias de Desenvolvimento. In Revista de Estudos Avançados, São Paulo, vol. 9, n. 25, set/dez, 1995.

SALOMÃO FILHO, Calixto. Comércio internacional e desenvolvimento. In: AMARAL JR., Alberto do e SANCHEZ, Michelle Ratton (orgs.). O Brasil e a ALCA: os desafios da integração. São Paulo: Aduaneiras, 2003, p. 535-555.

SAMUELSON, Paul. The pure theory of public expenditure. In: Review of Economics and Statistics, no 36, vol. 4, novembro de 1954, p. 387-9.

SATO, Eiiti. Comércio e crescimento na ordem econômica internacional. In: CHEREM, Mônica Teresa e DI SENA JR., Roberto (org.). Comércio internacional $e$ desenvolvimento: uma perspectiva brasileira. São Paulo: Saraiva, 2004, p. 32-57.

- A ordem internacional hoje: globalização, papel do Estado e bens públicos internacionais. Brasília, março de 2001.

SAUVÉ, Pierre. Trade, Education and the GATS: what's in, what's out, what's all the fuss about?. In: Management and Policy, v. 14, n. 3, novembro de 2002. Disponível em: $<$ www.oecd.org $>$.

SCHUMPETER, Joseph A. Teoria do desenvolvimento econômico. São Paulo: Abril, 2002.

SEN, Amartya K. Desenvolvimento como Liberdade. São Paulo: Companhia das Letras, 2000.

_. The Possibility of Social Choice. In The American Economic Review, v. 89, n. 3, jun. 1999.

_. Prefácio. In: BARRAL, Welber (org.). Direito e desenvolvimento: análise da ordem jurídica brasileira sob a ótica do desenvolvimento. São Paulo: Singular, 2005, pp. 1330.

SENGUPTA, Arjun. Realizing the right to development. In Development and change, v. 31, n. 3, Haia, Blackwell Publishers, Institute of Social Studies, 2000.

. On the theory and practice of the right to development. In: SENGUPTA, Arjun; NEGI, Archna e BASU, Moushumi (eds.). Reflections on the right to development. 
Nova Delhi: Centre for Development and Human Rights, Sage Publications, 2005, pp. 61-109.

SIKKINK, Kathryn. Human Rights, Principled Issue-Networks, and Sovereignty in Latin America. In International Organization, v. 47, n. 3, 1993, pp. 411 a 441.

SILVA NETO, Orlando Celso da. Liberalização do comércio e outros valores. In: BARRAL, Welber e PIMENTEL, Luiz Otávio (coord.). Comércio Internacional e Desenvolvimento, Florianópolis: Boiteux, 2006, pp. 87-113.

SINKONDO, M. H. De la fonction juridique du droit au développement. In Revue de Droit International et de Droit Comparé, n.4, Bruxelas, 1991.

SMITH, Robert. Notas sobre Universidade e desenvolvimento. In: A Universidade na encruzilhada. Seminário Universidade: por que e como reformar? Brasília, 6-7 Ago. 2003. Brasília: UNESCO Brasil, MEC 2003. pp. 95-99.

SMITH, Adam. A riqueza das nações: investigação sobre sua natureza e suas causa. $2^{\mathrm{a}}$ Ed. São Paulo: Nova Cultural, 1996 (vol. I e II - Os Economistas).

SOUSA, Mônica Teresa Costa. A vinculação entre comércio internacional e desenvolvimento : possibilidades reais ou quimera do mercado?. In: BARRAL, Welber e PIMENTEL, Luiz Otávio (coord.). Comércio Internacional e Desenvolvimento, Florianópolis: Boiteux, 2006, pp. 53-85.

STEINER, Henry J. e ALSTON, Philip. International Human Rights in context: law, politics, morals. 2a ed. Nova Iorque: Oxford University, 2000.

STIGLITZ, Joseph E. A globalização e seus malefícios : a promessa não cumprida de benefícios globais. Trad. Bazán Tecnologia e Linguistica. 2 ed. São Paulo: Futura, 2002.

. Knowledge as a Global Public Good. In: KAUL, Inge; GRUNBER, Isabelle e STERN, Marc A (orgs.). Global Public Goods: International Cooperation in the 21st Century. Oxford: Oxford University Press, 1999, p. 308-326.

STUDART, H. Faculdade em série. Nunca foi tão fácil abrir uma delas. Tanto, que até o Ministério Público desconfia. IstoÉ Dinheiro, São Paulo, 5 jun. 2002. Disponível em: $<$ http://www.terra.com.br/istoedinheiro/249/economia/249_faculdades_serie.htm>. 
THORSTENSEN, Vera. OMC - Organização Mundial do Comércio, 2 ed. São Paulo: Aduaneiras, 2003.

TILAK, Jandhyala B. G. Higher education: a public good or a commodity for trade ? Commitment to higher education or commitment of higher education to trade. In: Second Nobel Laureates Meeting in Barcelona, 2 dez. 2005.

TOMASEVSKI, Katarina. Unasked questions about economic, social, and cultural rights from de experience of the especial rapporteur on the right to education (1998-2004): A response to Kenneth Roth, Leonard S. Rubenstein and Mary Robinson. In: Human rights quaterly, $\mathrm{n}^{\circ} 27,2005$, p. 709-720.

TRINDADE, Antonio Augusto Cançado. A proteção internacional dos direitos humanos no limiar do novo século e as perspectivas brasileiras. In: FONSECA Jr., Gélson e CASTRO, Sérgio Henrique Nabuco de (orgs.). Temas de Política Externa Brasileira II. Rio de Janeiro: Paz e Terra, 1994.

O legado da Declaração Universal e o futuro da proteção internacional dos direitos humanos. AMARAL Jr., Alberto do, e PERRONE-MOISÉS, Cláudia (orgs). $O$ Cinqüentenário da Declaração Universal dos Direitos do Homem. São Paulo: Edusp/Fapesp, 1999, p. 13-54.

As Consultas Mundiais das Nações Unidas sobre a realização do Direito ao Desenvolvimento como um Direito Humano. In Boletim da Sociedade Brasileira de Direito Internacional, anos 42 e 43, n. 72/74, Rio de Janeiro, 1991.

- Direitos Humanos e Meio Ambiente - Paralelo dos Sistemas de Proteção Internacional. Porto Alegre: Sérgio Antonio Fabris, 1993, p. 176.

UNCTAD XII: daqui para onde?. In: Pontes entre o comércio e o desenvolvimento sustentável, vol. $4, \quad \mathrm{n}^{\mathrm{o}} 2$, abril de 2008. Disponível em: $<$ http://ictsd.net/news/pontes/?volume=4\&number=2>.

UNESCO. Carta de Constituição. Paris, 1945. Disponível em: <www.unesco.org>. Declaração Mundial sobre Educação Superior no Século XXI: Visão e Ação. Paris, 1998. Disponível em: <www.unesco.org>.

What it is? What it does? Paris, 2003. Disponível em: <www.unesco.org>. 
WITKOWSKA, Maria Magdalena Kenig. The UN Declaration on the Right to Development in the Light of its Travaux Preparatoires. In: DENTERS, Erik; PETERS, Paul e WAART, Paul de (eds.). International Law and Development. Dordrecht: Martinus Nijhoff Publishers, 1988, pp. 381-388.

WOLKMER, Antonio Carlos e WOLKMER, Maria de Fátima S. Direitos humanos e desenvolvimento. In: BARRAL, Welber (org.). Direito e desenvolvimento: análise da ordem jurídica brasileira sob a ótica do desenvolvimento. São Paulo: Singular, 2005, pp. 61-72. 